Linköping Studies in Science and Technology

Dissertations, No.1776

\title{
The Internationalization of SMEs: An Interactive Perspective of Firm-Level Entrepreneurship and Network Structure
}

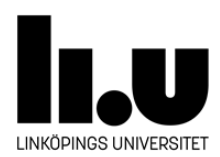

2016

Department of Management and Engineering Linköping University, SE-581 83 Linköping 
Cover: The picture is originally from Nelson and JJ Hayes' (1935) book, illustrated by Paul McPharlin, republished by http://puppetnet.com.

(C) Mojtaba Hosseini, 2016 (Unless otherwise noted)

The Internationalization of SMEs: An Interactive Perspective of Firm-Level Entrepreneurship and Network Structure

Linköping studies in science and technology,

Thesis No. 1776

ISBN: 978-91-7685-734-2

ISSN: 0345-7524

Printed by: LiU-Tryck, Linköping

Distributed by:

Linköping University

Department of Management and Engineering

SE-581 83 Linköping, Sweden

Tel: +4613 281000, fax: +4613281873 
To my wife Nasrin

And my son Arvin 


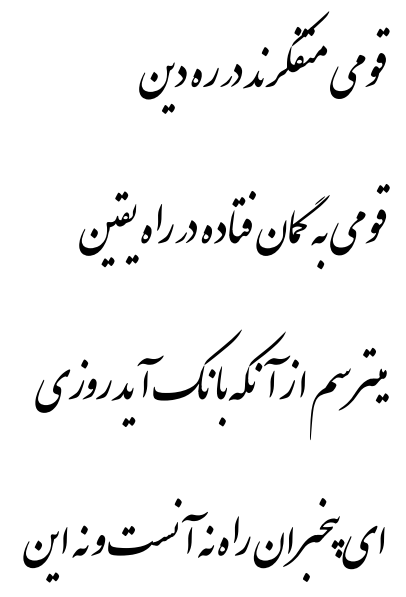

Alike for those who for TO-DAY prepare, And those that after a TO-MORROW stare, A Muezzin from the Tower of Darkness cries "Fools! your Reward is neither Here nor There."

Omar Khayyam

Translated by Edward FitzGerald 


\section{Abstract}

The positive relationship of firm-level entrepreneurship and performance has received much attention in recent years and has become an attractive title in the entrepreneurship literature. This popularity encourages researchers to study the role played by the phenomenon on other organizational outputs such as internationalization. Fortunately, the idea of the interaction of entrepreneurship and internationalization has been greatly welcomed, and a number of conceptual papers have been published to decipher and describe it. A new movement emerged that has established a new field of study, frequently known as international entrepreneurship (IE). Until now, the majority of international studies have put their attention on the conceptual explanation of the interaction, and the number of empirical studies on the subject is few. Furthermore, almost all the empirical studies have been performed in developed and emerging markets, and developing areas such as the Middle East are nearly ignored. This is where the literature needs the necessary attention to help bridge the gap.

In the real context of Iranian business, policymakers support entrepreneurship as a proven way to improve the internationalization of smaller companies. Following this assumption, several supportive plans have been designed and executed which aim to increase the entrepreneurial status of SMEs as a way to enhance their internationalization. The annual budget assigned to these plans tremendously raises the cost of Iranian public organizations. A question worth answering here is: Does having a better entrepreneurial stature mean better internationalization for Iranian SMEs? To answer this question and to fill the gap in the literature on the subject, this research explains the relationship of firm-level entrepreneurship and the internationalization of Iranian SMEs.

Looking at the current studies has revealed a prolonged challenge in the conceptualization and operationalization of firm-level entrepreneurship. Different researchers have suggested different concepts and measurements to study the phenomenon. To resolve this problem and to respect a broad conceptualization of entrepreneurship and the entrepreneurship process, a profile measurement model was employed in which companies are classified into four different groups: non-entrepreneurial, forced entrepreneurial, latent entrepreneurial, and actual entrepreneurial. This profile model incorporates the two popular constructs of entrepreneurial orientation and corporate entrepreneurship to determine the entrepreneurial stature of a company. Combining these concepts in a profile measurement model helps the research to avoid the problems of current synthesizing measurements at the cost of losing a part of the variance.

Surprisingly, while the literature predicted the highest level of internationalization in terms of internationalization involvement, international performance, and the speed of internationalization for actual entrepreneurial companies, the forced entrepreneurial firms showed the best internationalization in reality. The only exception was when the environments became very hostile, in which the actual entrepreneurial SMEs suppressed the forced entrepreneurial, showing better internationalization. These unexpected conclusions led the researcher to consider why the forced entrepreneurial type displayed the highest level of internationalization, while it was expected that the actual entrepreneurial profile would show the most. A primary investigation of the forced entrepreneurial companies, accompanied with a quick literature review, pointed to the business network as another factor that should be considered. A case study approach was 
deployed to delve into the subject and explain how entrepreneurial companies use network structures to amplify their internationalization.

Four cases, one from each profile, were selected. Because the actual entrepreneurial category is the reference group of the study and the first case of this type was a domestic company, a contrast case - an international actual entrepreneurial company - was also selected to supply a more detailed cross-case analysis. Following the literature-driven analytical framework, which counted actor type, structural holes, and network closure as important network characteristics in the internationalization of SMEs, the results of the case studies confirmed the importance of actor type in the decision to enter a foreign market, structural holes in identifying international opportunities, and network closure in realizing the opportunities. In simpler words, the forced entrepreneurial company held a better position to receive the information about international markets because most actors who dealt with them where international companies. In addition, it enjoyed an external network rich of structural holes and a dense internal network, which respectively facilitated the exploration and exploitation of subsequent international opportunities.

All in all, however, firm-level entrepreneurship seems an important factor of companies' internationalization that could somehow justify why entrepreneurial companies show better international activities than non-entrepreneurial firms, but it is not able to explain how different types of entrepreneurial companies could hold different levels of internationalization. This is the mutual interaction of entrepreneurial status and the network structure that presents a powerful explanation of the difference in internationalization among companies. Therefore, researchers are invited to focus more on a configurational analysis of firm-level entrepreneurship, network structure, and internationalization, and policymakers are recommended to see both entrepreneurship and business networks when they design a supportive plan to improve the internationalization of SMEs. 


\section{Sammanfattning}

Det positiva sambandet mellan entreprenörskap studerat på företagsnivå och företagens (ekonomiska) resultat har under de senaste åren rönt mycket uppmärksamhet i litteraturen om entreprenörskap. Det ökade intresset uppmuntrar forskare att ytterligare studera de effekter som entreprenörskap har inom andra områden, såsom internationalisering. Idén om samspelet mellan entreprenörskap och internationalisering har tagits emot mycket positivt inom akademien, och ett antal konceptuella artiklar har publicerats för att beskriva och analysera detta samspel. Det har lett till att ett nytt område har etablerats, som oftast går under benämningen internationellt entreprenörskap (IE). Hittills har de flesta internationella studierna fokuserat på konceptuella förklaringar av interaktionen, medan antalet empiriska studier i ämnet är få. Dessutom har nästan alla empiriska studier utförts på utvecklade marknader eller s.k. "emerging markets". Marknader som är under (tidigare) utveckling som marknaderna i Mellanöstern har nästan helt ignorerats, och dessa behöver också uppmärksammas i strävan efter att fylla gapet i forskningen.

Det iranska affärslivet präglas av att det politiska systemet på policynivå stödjer entreprenörskap som ett beprövat sätt att förbättra möjligheterna till internationalisering av mindre och medelstora företag (SME-företag). Ett flertal övergripande planer har utformats och genomförs med syfte att öka den entreprenöriella kompetensen (statusen) hos SME-företag som ett sätt att öka deras internationalisering. Den årliga budget som avsatts för att realisera dessa planer har väsentligt ökat kostnaderna för berörda iranska offentliga organisationer. En fråga som är värd att ytterligare undersöka är: Leder en förbättrad entreprenöriell kompetens (status) också till en mera lyckosam internationalisering för iranska SME-företag? Denna fråga utgör det centrala temat i förevarande avhandling - hur relationen mellan entreprenörskap på företagsnivå och internationalisering ser ut bland iranska SME-företag.

Om man tittar på de aktuella studier som finns så har den akademiska utmaningen under lång tid varit inriktad mot konceptualisering och operationalisering av entreprenörskap på företagsnivå. Olika forskare har föreslagit olika koncept och metoder för att mäta och studera detta fenomen. För att lösa detta problem rörande relationen mellan entreprenörskap och internationalisering har i denna avhandling en bred konceptualisering av entreprenörskap och entreprenörskapsprocessen utvecklats - en modell där SME-företagen indelas i fyra olika grupper: "icke-entreprenöriella", "tvingade entreprenöriella", "latent entreprenöriella" och "faktiskt entreprenöriella" företag. Denna modell införlivar de två vanligaste koncepten - entreprenöriell orientering och företagsentreprenörskap (corporate entrepreneurship) - för att bestämma den entreprenöriella statusen på ett enskilt företag. En kombination av dessa begrepp i en och samma modell hjälper forskningen att undvika de problem som finns kopplade till de nuvarande syntetiserade måtten, vars användning sker på bekostnad av att man förlorar en del av variansen i de statistiska analyserna.

Överraskande uppstod det ett gap mellan vad litteraturen predikterar och vad den empiriska studien visar avseende vilka företag som nådde den högsta graden av internationalisering i termer av omfattning, prestationer och hastighet. Litteraturen pekar på de "faktiskt entreprenöriella" som den främsta gruppen, medan studien visar på att det är de "tvingat entreprenöriella. Det enda undantaget var när affärsmiljöerna var tydligt fientliga, där de "faktiskt 
entreprenöriella" SME-företagen visade de bästa resultaten. Dessa oväntade slutsatser ledde till fortsatta frågeställningar om varför så var fallet. En första undersökning av "tvingade entreprenörsföretag”, tillsammans med en litteraturgenomgång, pekade ut affärsnätverk som en ytterligare faktor som bör övervägas i sammanhanget. En multipel fallstudie designades för att beskriva och förklara hur entreprenöriella företag använder nätverksstrukturer för att förstärka sin internationalisering.

Fyra fallföretag, ett från varje profil, valdes. Eftersom kategorin "faktiska entreprenörsföretag" används som referensgrupp till studien och då det första fallföretaget av detta slag var ett inhemskt företag, valdes också ett "kontrasterande" fall - ett internationellt företag för att kunna säkra en mer detaljerad tvärsnittsanalys. Det litteraturdrivna analytiska ramverket, använde tre nätverksegenskaper för internationalisering av SME-företag: typ av aktörer, strukturella hål och närhet i nätverken. Resultaten från fallstudierna bekräftade: 1/ vikten av typ av aktör för beslutet att gå in på en utländsk marknad, 2/ vikten av strukturella hål för att identifiera internationella möjligheter och 3/ vikten av närhet i nätverken för att förverkliga möjligheterna. Uttryckt på ett enklare sätt håller "tvingade entreprenörsföretag" en starkare position för att ta emot information om den internationella marknaden, eftersom de flesta aktörer som de har en relation med redan är internationella företag. Dessutom uppvisar företagen i den kategorin externa nätverk som är rika på strukturella hål och även har täta interna nätverk, vilket båda underlättar arbetet med att undersöka och utnyttja de internationella möjligheterna.

Allt som allt, pekar de empiriska studierna på att entreprenörskap på företagsnivå är en viktig faktor för företagens internationalisering och som till viss del förklarar varför entreprenörsföretag visar på en bättre internationell verksamhet än icke-entreprenörsföretag. Däremot har studien inte kunna förklara hur olika typer av entreprenörsföretag når upp till olika nivåer av internationalisering. Det är växelverkan mellan den entreprenöriella statusen och nätverksstrukturen som utgör en kraftfull förklaring av skillnaden i internationalisering bland företag. Därför uppmanas forskare att fokusera på en konfigurativ analys av entreprenörskap på företagsnivå tillsammans med nätverksstruktur och internationalisering. Beslutsfattarna policynivå rekommenderas att se till både entreprenörskapet och företagsnätverken när de utformar en stödjande plan för att förbättra internationaliseringen av SME-företag. 


\section{Acknowledgement}

If you ask students to tell you the most difficult part of a PHD thesis, they may point to a given chapter or a specific step in their process of performing the research. In my opinion, however, neither a chapter, a step of the process, nor the whole research could be possible without receiving generous support from other people who "have your back". Appreciating and acknowledging the people who made this work possible is the most difficult part of my thesis. There are no words or expressions that could be powerful enough to express my true feelings about this. Hereby, I apologize to all of the people - to my colleagues and friends who have assisted me in so many ways - if I forget to mention your names. I am extremely grateful for having all of you around and express my gratitude to you with all of my heart.

I would like to express special thanks and appreciation to my advisors, Professors Hossein Dadfar and Steffan Brege. You have always stood beside me and helped me to overcome all the frustrations and challenges that I faced as a $\mathrm{PhD}$ student. Your academic knowledge and enlightening advice were always helpful, kept me on the right track, and encouraged me to step onto new and interesting ground. I really value all the priceless experience that I have gained while working with you.

A special thanks to Professor Karl Wennberg. Words cannot express how much I appreciate your instructive comments and ideas to modify and improve my writing. I learnt a lot from your knowledge and the way that you organize and present your comments and suggestions. It is an honor to have your suggestions and recommendations in my research.

Last but not least, I would like to give my deepest thanks and appreciation to my family, my mother and my father who lighten my path ahead and made sacrifices on my behalf. Heartfelt thanks to my mother-in-law and my father-in-law, who support me and whose prayers for me are what have sustained me thus far. A very special thanks for my beloved wife, Nasrin, who always stood by me during this long-lasting journey and has walked with me through all the challenges we have faced. Honestly, I am not skillful enough in English to express how grateful I am to have you as a dedicated partner and supporter. 


\section{Table of Contents}

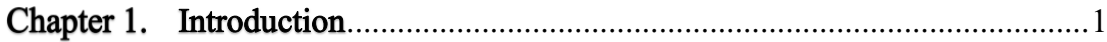

1.1. Internationalization: Defining the Concept .........................................5

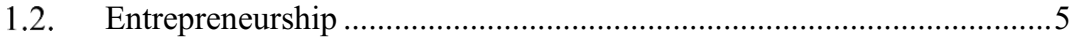

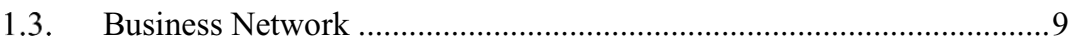

1.4. Research Purpose and Questions ...................................................... 11

1.5. Research Process and Thesis Structure ........................................... 12

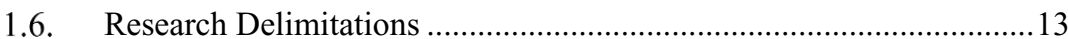

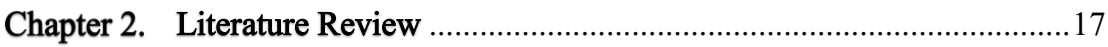

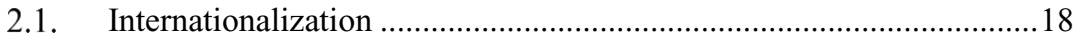

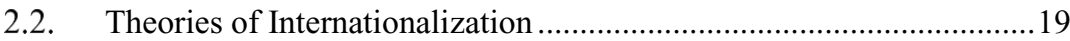

2.2.1. Economic Perspective ................................................................20

2.2.2. Stage Perspective ...........................................................................22

2.2.3. Network Perspective .................................................................25

2.2.4. International Entrepreneurship ................................................28

2.3. Theoretical Framework of the Research ...............................................31

2.4. Firm-Level Entrepreneurship ........................................................ 37

2.5. Entrepreneurial Orientation.............................................................. 41

2.6. Corporate Entrepreneurship ............................................................... 51

2.7. A Profile Measurement Model of EO-CE...............................................54

2.8. Firm-Level Entrepreneurship and Internationalization......................64

2.9. Networks and Internationalization ......................................................94

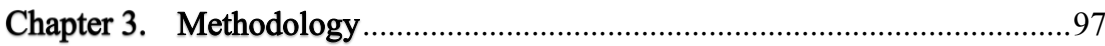

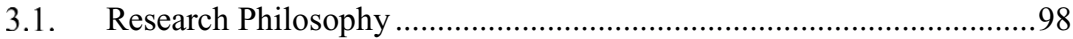

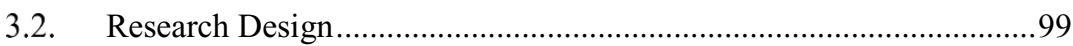

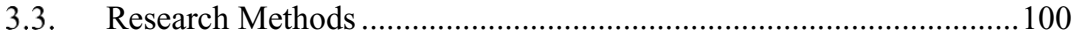

3.3.1. Section One: Survey Study..................................................... 100

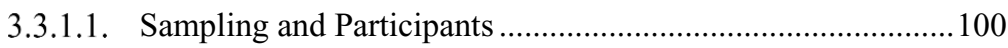


3.3.1.2. Research Variables and Measurements .................................104

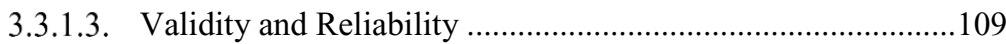

3.3.1.4. Quantitative Data Analysis ................................................111

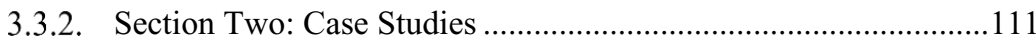

3.3.2.1. Selection and Analysis of the Cases .....................................113

3.3.2.2. Case Study Trustworthiness .............................................115

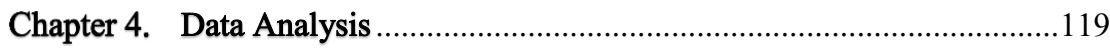

4.1. The Statistical Analysis of the Survey Data ......................................119

4.1.1. Confirmatory Factor Analysis ................................................120

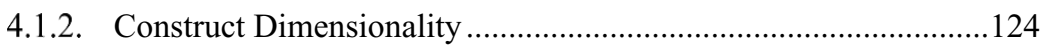

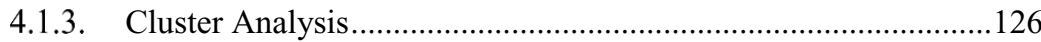

4.1.4. Testing the Hypotheses.......................................................... 128

4.1.4.1. Firm-level entrepreneurship and international involvement ..130

4.1.4.2. Firm-level entrepreneurship and international scale .............132

4.1.4.3. Firm-level Entrepreneurship and International Scope...........137

4.1.4.4. Firm-level Entrepreneurship and the Speed of

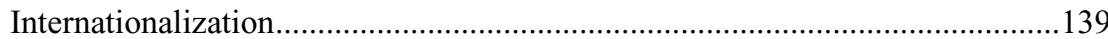

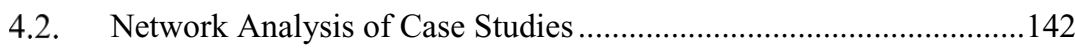

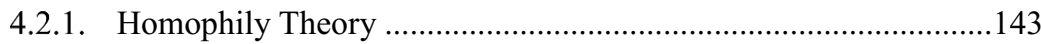

4.2.2. Structural Holes Theory.............................................................. 144

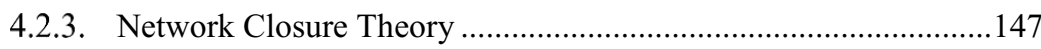

4.2.4. A Network Analytical Framework .............................................148

4.2.5. Case One: The Forced Entrepreneurial Company ........................152

4.2.6. Case Two: The Actual Entrepreneurial Company.........................156

4.2.7. Case Three: The Latent Entrepreneurial Company .......................157

4.2.8. Case Four: The Non-Entrepreneurial Company ...........................159

4.2.9. Contrast Case: The Internationalized Actual Entrepreneurial Company 161

4.2.10. Cross-Case Analysis . .162 
Chapter 5. Discussion and conclusion.............................................................. 167

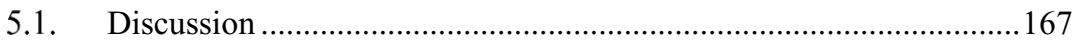

5.1.1. EO and CE: The Measurement Characteristics ………….............167

5.1.2. Profiling Companies: EO versus CE ...........................................171

5.1.3. Entrepreneurship and Internationalization ...................................172

5.1.4. Role of Business Networks ...........................................................174

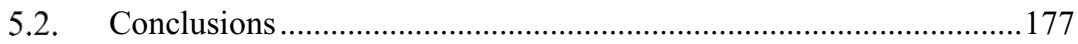

5.3. Research Contributions ………………………………………........... 179

5.4. Managerial Implications...................................................................... 181

5.5. Tips for Future Research ..................................................................... 182 


\section{List of Tables}

Table 2-1: The well-known definitions of internationalization ..........................19

Table 2-2: The perspectives and theories of Internationalization ........................32

Table 2-3: A literature review of firm-level entrepreneurship, performance, and

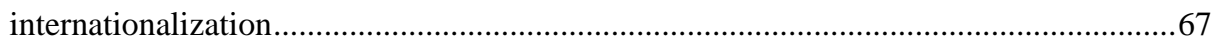

Table 3-1: Research variables and measurements ...........................................109

Table 4-1: The convergent and discriminant validity of measurements ............124

Table 4-2: Unidimensional versus multidimensional models of EO and CE ....125

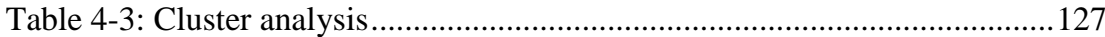

Table 4-4: The statistical descriptions of clusters ............................................127

Table 4-5: The contrast coding of firm-level entrepreneurship .......................129

Table 4-6: The cross-tab analysis of international involvement .......................131

Table 4-7: The cross-tab analysis of international involvement and environment

Table 4-6: The regression analysis of international scale, scope, and speed .....135

Table 4-7: The results of the hypotheses testing ............................................. 141

Table 4-8: The network description of the selected cases...................................164

Table 4-9: The network position analysis of the ego and the powerful actors ..164

Table 4-10: The network analysis of the selected cases ....................................165 


\section{List of Figures}

Figure 2-1: Theoretical framework of the research..............................................34

Figure 2-2: The profile model of firm-level entrepreneurship............................60

Figure 2-3: The conditional effect of entrepreneurship ...................................99

Figure 4-1: The simple slope analysis of the international scale and environmental hostility (FE vs. AE)

Figure 4-2: The simple slope analysis of the international scope and environmental hostility (FE vs. AE)

Figure 4-3: The simple slope analysis of the speed of internationalization and environmental hostility (FE vs. AE)

Figure 4-4: The structural indicators of redundancy (Adopted from Burt (1992))

Figure 4-5: The optimized network of structural holes and closure (Adopted from Burt (2000, 2001b)) 150

Figure 4-6: The network framework analysis of international entrepreneurship 152

Figure 4-7: The network structure of the forced entrepreneurial company 154

Figure 4-8: The network structure of the domestic actual entrepreneurial company

Figure 4-9: The network structure of the latent entrepreneurial company

Figure 4-10: The network structure of the non-entrepreneurial company 158

Figure 4-11: The network structure of the international actual entrepreneurial firm 


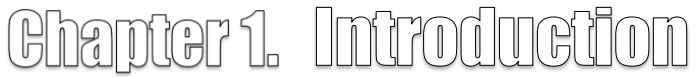

The substantial role played by smaller companies in employment, job creation, and even economic development is a well-known scenario in nearly all business textbooks, empirical studies, and institutional reports on small and medium-sized enterprises (SMEs). Statistical figures and practical reports in almost all countries support this claim. A typical report performed by the United Nations Industrial Development Organization (UNIDO) alleged that approximately $90 \%$ of private businesses around the world are SMEs, which are responsible for more than $50 \%$ of total employment (UNIDO, 2003). In the EU, the foundation of the economy is built upon SMEs (Wymenga, Spanikova, Derbyshire, \& Barker, 2011); about $99.8 \%$ of 20.8 million non-financial businesses are SMEs, and most of them (nearly 92\%) are micro-businesses with fewer than 10 employees (de Kok et al., 2011). A similar story has been echoed by statisticians and practitioners in developing countries such as Iran. Around 99.8\% of all Iranian registered companies (UNIDO, 2003) or perhaps more (Zohari, 2008) are SMEs, of which $98.4 \%$ are characterized as microbusinesses (UNIDO, 2003).

Considering the indisputable contribution of SMEs in a whole economy, their predominant role in employment and job creation should not be a surprise. SMEs have deeply influenced the economic development of the EU and create more than $67 \%$ of all jobs around the continent (de Kok et al., 2011). In a same vein, around 54.6\% of all Iranian employees are recruited by SMEs (UNIDO, 2003). SMEs are also responsible for a large portion of employment growth. For instance, $85 \%$ of employment growth in the EU 
between 2002 and 2010 was generated by SMEs (de Kok et al., 2011), and it became even more promising in 2011 (Wymenga et al., 2011). All these statistics and figures only demonstrate a short description of the importance of smaller companies in the economy of the world, the EU, and Iran (for more detail see the UNIDO reports ${ }^{1}$ ).

In the recent era of advancements in technology and communications, a surge of globalization has pushed all countries and companies to engage in international activities. As a result, all types of economic activities are becoming more globalized, and a worldwide system of production and distribution is gradually evolving (Acs \& Preston, 1997). This movement, which began in the last century, is going forward with a tremendous velocity and changes the structure of current business. In the beginning of this century, Gilpin (2002, p. 13) strongly warned about this forthcoming phenomenon;

A number of books proclaim that, whether we like it or not, global capitalism and economic globalization are here to stay. Unfettered markets, they argue, now drive the world and all must adjust, however painful this may be.

New technological breakthroughs, particularly in information processing, telecommunications and biotechnology, consolidate the pace and domain of this revolutionary movement (Acs \& Preston, 1997). In alignment with external forces, a number of internal policies have been regulated in some countries that drive companies, especially SMEs, to move with the surge of globalization. Decreasing the direct subsidiaries and governmental supports is a typical example of these kinds of policies and business regulations (Etemad, 1999). In short, a new epoch of internationalization has begun in which the threat of international competition becomes a reality. Internationalization affects all companies around the world as formulating strategies without considering it may cause failure or even collapse in the long term. Despite the risk of ignoring or not engaging in internationalization, many Iranian SMEs have still focused on the domestic market and their international activities remain very limited. The main

${ }^{1}$ http://www.unido.org/en/resources.html 
reason behind their ignorance is the challenges that SMEs are facing when they want to expand their international activities.

These challenges are commonly investigated under the label "internationalization barriers of SMEs", and have attracted much attention in the current stream of the literature. Internationalization barriers refer to the factors that decrease the capacity of a company to start, perform, expand or sustain its activities in international markets. They are classified as internal and external impediments (Leonidou, 2004; Leonidou, Katsikeas, Palihawadana, \& Spyropoulou, 2007). Internal impediments are related to a firm itself and usually occur because of a lack of resources, while external barriers are beyond the firm's control and are imposed by the business environment. Internal barriers can be further classified as functional and marketing-related (Leonidou, 2004; Tesfom \& Lutz, 2006). The functional barriers are created by limitations of human capital, resources and production processes that restrict the implementation of proper strategies to meet demands and secure success in international markets. On the other hand, marketing impediments influence the ability of a company to effectively price, distribute, and promote its products and services in international markets.

In the literature, entrepreneurship has been mentioned as a distinct attribute of smaller companies which helps to overcome the barriers of internationalization and enables them to compete with larger companies. Actually, SMEs need to accept a calculated level of risk to seize entrepreneurial opportunities and introduce new products and services that are highly demanded in international markets (Achtenhagen, 2011). Therefore, most supportive and promotional plans and policies that are designed and carried out by private and public sectors in Iran have focused on promoting entrepreneurship as a means to improve internationalization (Talebi, Tajeddin, Rastgar, \& Emami, 2012). For example, the Globalization Policy (2006) and Trade and Industrial Polices (2005-2009) outline supporting entrepreneurship and job creation activities as a prominent policy to improve the competitive advantage of SMEs (Zohari, 2008). To 
execute this policy, a number of political and educational institutions ${ }^{1}$ are working together at great cost and time.

Briefly speaking, SMEs are an important part of the economy and are forced to compete with international companies who threaten their long-term survival and success. Unfortunately, they are not able to effectively compete because of their functional and marketing limitations. The literature suggests improving SMEs' entrepreneurial activities as a solution. Entrepreneurship helps SMEs to overcome those limitations and facilitate their internationalization. Fortunately, this solution is highly admired by the Iranian public and education sector, and several expensive promotional plans have been developed to stimulate SMEs' entrepreneurial activities. With attention to the scant number of empirical studies investigating the relationship of entrepreneurship and internationalization, especially in developing countries, and the ambiguity surrounding the association of entrepreneurship and performance, there is a need for research on firm-level entrepreneurship and internationalization among Iranian SMEs.

An important aspect that should be considered in any internationalization study, and which is required to understand the phenomenon, is the context in which a company operates, such as industry, business environment and the firm's network of relationships (Madsen \& Servais, 1997; Meyer \& Skak, 2002). In fact, industry and business environment can provide SMEs with proper strategies, and networks assist them to overcome their barriers through providing complementary resources and required knowledge (Chetty \& Wilson, 2003; Madsen \& Servais, 1997). Business networks do not only influence, but also have a very strong effect on starting and improving the internationalization process (Johanson \& Mattsson, 1988; Meyer \& Skak, 2002). Consequently, incorporating entrepreneurship and business networks could be enlightening in many ways: first, it is a timely response to a highly recommended subject of study that is to some extent ignored (Coviello \& Munro, 1997; Ghauri, Lutz, \& Tesfom,

\footnotetext{
${ }^{1}$ These institutions include the Ministry of Cooperatives, Labor and Social Welfare, the Labor and Social Security Institute, Iran Small Industries and Industrial Parks, the Iran Technical and Vocational Training Organization, the University of Tehran, the Ministry of Health and Medical Education, and the Ministry of Petroleum.
} 
2003); second, it delivers a more realistic explanation of internationalization because internationalization is actually a continuous reorganization process that happens in a dynamic network context (Mattsson, 2003); and third, research that incorporates entrepreneurship, networks and internationalization has greater potential to describe the internationalization of smaller companies (Chetty \& Stangl, 2010; Coviello \& Munro, 1997). In fact, including actors and their interactions is a necessary part of an internationalization study that enables international managers and practitioners to yield a better explanation and prediction of the process (Boso, 2010).

\subsection{Internationalization: Defining the Concept}

Similar to other business and management concepts, internationalization is defined and studied in different, sometimes confusing ways. For instance, one stream of research defines the concept as an incremental process of increasing involvement in international markets (Johanson \& Vahlne, 1977; Welch \& Luostarinen, 1988), while another stream explains it as an adaptation of organizational activities in international contexts (Calof \& Beamish, 1995). By summarizing the current definitions, and with respect to the research purpose, internationalization in this study is defined as a process of incremental or fast involvement in international markets that increases the awareness of international influence, is encouraged by a company's network position or entrepreneurial opportunities, leads to cross-border transactions, and needs adaptation of the firm's operations (for more detail see Chapter Two, Section One). It is conceptualized as a multidimensional construct of international scope, international scale, and the speed of internationalization, which cover different aspects of the phenomenon and are very common in the literature.

\subsection{Entrepreneurship}

Reviewing the entrepreneurship literature reveals two broad streams of research: start-up and firm-level entrepreneurship. Separating these streams, and defining their unique objectives and contexts, are very helpful in positioning a research study and understanding entrepreneurial behaviors (Stevenson \& Jarillo, 1990). Start-up entrepreneurship defines individual entrepreneurs as the unit of analysis and targets their characteristics, behaviors 
and the process that they follow to run a new company (e.g. Carland, Hoy, Boulton, \& Carland, 1984; Orhan \& Scott, 2001). Firm-level entrepreneurship, in contrast, has chosen a wider perspective, focuses on the whole firm and takes the overall entrepreneurial activities of a firm at the center of attention (e.g. Covin \& Slevin, 1989; Lumpkin \& Dess, 1996a; Miller, 1983; Zahra, 1991). While the former focus on understanding how a new company is created, the latter aims at established companies to theorize a model of entrepreneurial activities that improves corporate performance. This study is clearly classified as firm-level entrepreneurship research, as it focuses on already-established SMEs to understand to what extent being and acting entrepreneurial could influence their internationalization.

Entrepreneurship is a general expression, one that is difficult to define and surrounded by long-lasting confusion. The literature contains a number of studies that have attempted to present a clear-cut but all-inclusive definition of the phenomenon (Morris, Kuratko, \& Covin, 2008; Shane \& Venkataraman, 2000; Stevenson \& Jarillo, 1990). Based on a quick glance at those endeavors, the main themes underlying existing definitions begin to surface: (1) the entrepreneur, a principal actor in the company who plays the major part in pursuing entrepreneurial strategies; (2) the process of entrepreneurship as a sequence of opportunity exploration and exploitation; and (3) new products, services, ventures and organizational renewing as the outcomes of the entrepreneurship process. Focusing on entrepreneurship as the process of opportunity exploration and exploitation is an informative way of defining firm-level entrepreneurship because it does not restrict the entrepreneurial act solely to an individual level. Therefore, firm-level entrepreneurship is defined as the process of discovering, evaluating, and exploiting business opportunities by organizations to create future products and services (Kreiser, 2005), and may lead to new ventures and organizational renewing.

Researchers have used different names and labels for firm-level entrepreneurship such as strategic posture (Covin \& Slevin, 1989), corporate entrepreneurship (Zahra, 1991), entrepreneurial orientation (Lumpkin \& Dess, 1996a), entrepreneurial management (Stevenson \& Jarillo, 1990), and intrapreneurship (Pinchot, 1986). Although these names and labels are applied interchangeably in some empirical studies, in this research, in order 
to respect the nomological network of firm-level entrepreneurship, the precise definitions of original studies, and in line with the research purpose, are defined differently. In fact, each name or label just covers one dimension of firm-level entrepreneurship, and none of them could be a true representative. Consequently, interchangeable use of those constructs may lead to inconsistent or even contradictory findings (Lyon, Lumpkin, \& Dess, 2000). A majority of studies have implemented Entrepreneurial Orientation (EO) to study firmlevel entrepreneurship (e.g. Covin \& Slevin, 1989; Lumpkin \& Dess, 1996a; Wiklund \& Shepherd, 2005), but EO has been criticized (e.g. Simsek, Veiga, \& Lubatkin, 2007; Zahra, 1991, 1993b) as a construct that only measures the orientation toward entrepreneurship rather than actual entrepreneurial activities. In response to those critics, the construct of Corporate Entrepreneurship (CE) was developed, which focused on the actual entrepreneurial behavior of companies. Unfortunately, CE is also a one-dimensional measurement of firm-level entrepreneurship that only gauges the entrepreneurial outcomes and disregards the initial orientation. In short, each construct of EO or CE just measures one and only one dimension of firm-level entrepreneurship, and none can draw an in-depth picture alone; thus, a combination of both is required to achieve a moreinclusive view.

Theoretically speaking, entrepreneurial companies may have more successful internationalization because they are able to recognize international opportunities faster than their rivals and take the required risks to realize them. Regardless of this convincing theoretical explanation and call for more attention (Guth \& Ginsberg, 1990), the number of empirical studies which investigate the relationship between entrepreneurship and internationalization remains few (O'Cass \& Weerawardena, 2009; Ortiz de Urbina Criado, Montoro Sânchez, \& Romero Martînez, 2011) and is limited in scope. The current literature adheres more to theoretical debate rather than empirical investigation of entrepreneurship and internationalization. Given that, a number of seminal conceptual papers have been published on the subject, which build the foundation of International Entrepreneurship (IE) (e.g. Mcdougall, 1989; McDougall \& Oviatt, 2000; McDougall \& Oviatt, 2003; Oviatt \& McDougall, 2005a, 2005b; Zahra, 2005; Zahra \& George, 2002). IE research has studied the exploration and exploitation of entrepreneurial opportunities 
in international markets. In the beginning, it focused on the shared area of EO and internationalization, and defined its domain as innovative, proactive and risky activities in international markets that may create value for companies (McDougall \& Oviatt, 2000). This definition was later modified, and IE was explained as discovering, enacting, evaluating, and exploiting opportunities across borders to create new products and services (Oviatt \& McDougall, 2005a). Some studies of IE conceptualize the internationalization of SMEs as a particular form of entrepreneurship (Andersson, 2000; Ibeh \& Young, 2001; Knight, 2000; e.g. Knight \& Cavusgil, 2004; Lu \& Beamish, 2001); however, a majority of research on firm-level entrepreneurship and internationalization still defines the former as a predictor variable and the latter as an outcome (Covin, Green, \& Slevin, 2006).

Altogether, the conceptual foundation of IE is built on the interaction of entrepreneurship and internationalization, but the number of empirical studies in the field remains few and the scope limited. Furthermore, there is no universal agreement on their findings: while some studies found a positive relationship between firm-level entrepreneurship and internationalization (e.g. Acedo \& Jones, 2007; Zahra, Hayton, Marcel, \& O'Neill, 2001), others could not demonstrate a conclusive relationship (e.g. Dimitratos, Lioukas, \& Carter, 2004; Kropp, Lindsay, \& Shoham, 2006). This confusion is not limited to IE studies; the research on entrepreneurship and corporate performance also suffers from this kind of disagreement. A primary solution to this problem, one highly recommended by entrepreneurship researchers, is to include moderator variables such as environmental factors to obtain a deeper understanding (Covin \& Slevin, 1989; Lumpkin \& Dess, 1996a; Zahra \& Covin, 1995). Environmental factors are usually considered as key drivers for the internationalization of SMEs (Zhang, Ma, \& Wang, 2012). Among all possible environmental variables that may influence the internationalization of SMES, environmental dynamism and environmental hostility found more popularity in the literature (Khandwalla, 1977; Miller \& Friesen, 1982), and thus are included in this study.

In summary, studying the effect of firm-level entrepreneurship and internationalization in Iran, and especially implementing a research design consisting of moderator variables, is highly demanded because: (1) the number of empirical studies on international entrepreneurship, despite its fairly comprehensive conceptual foundation, is 
very limited; (2) there is confusion among the empirical findings, as part of the research has demonstrated a positive association between entrepreneurship and internationalization, while other studies could not find conclusive results; (3) paying more attention to the empirical investigation of internationalization is greatly advised (Zahra, Randerson, \& Fayolle, 2013b); and (4) the context of the research is a new, previously ignored area that needs to be studied more. Executing this type of research in a neglected area such as Iran may improve the overall generalizability of the literature, and can shed some light on the blind spots of previous studies. Thus far, the majority of firm-level entrepreneurship studies have been performed in the United States and other developed countries (Tang, Tang, Marino, Zhang, \& Li, 2008), and there is little understanding of the phenomenon in developing regions such as the Middle East, Latin America, Sub-Saharan Africa, Eastern Europe, and South Asia (Wales, Gupta, \& Mousa, 2011).

\subsection{Business Network}

In the modern era of business, in which traditional competitive markets are being replaced with cooperative networks, every company can be viewed as a small member of a bigger and more complex collaboration. The number of international actors and the overall structure of a business network affect the international activities of its members, and should be considered as an integral part of an IE network study. Being a part of an international group helps companies to recognize profitable opportunities faster because it affords related and in-depth information from foreign markets. It also facilitates opportunity exploitation through cooperation and by sharing technologies, skills and resources. This is extremely important in the internationalization of SMEs because they suffer from critical limitations, which diminish their potential to enter and remain in an international market. Perhaps networking is the most effective solution to overcome the barriers of internationalization (Coviello \& McAuley, 1999; Yeoh, 2004).

In summary, business networks help smaller firms to overcome their obstacles in international markets, and increase their potential to identify and exploit international opportunities. They are useful in explaining the scale, scope, and speed of internationalization (Coviello, 2006), and should be viewed as an essential part of 
international entrepreneurship. Reviewing the literature reveals that a single theory which could be able to fully explain internationalization does not exist (Jones \& Coviello, 2005; Spence \& Crick, 2006). This means that even the network perspective, with all its potential, is not able to provide a full understanding of internationalization alone. Consequently, it is advised to apply a mixture of theories, including the business network, in order to supply a clear explanation of the phenomenon (Ibeh \& Kasem, 2011). This is a matter of high importance, particularly in the case of SMEs, where a single theory that could be fully matched is not available, and where the network perspective is considered as a necessary part of their internationalization (McAuley, 1999). In fact, business networks shape the context of internationalization (Jones \& Coviello, 2005; Knight \& Cavusgil, 2004; Loane \& Bell, 2006; Sharma \& Blomstermo, 2003), and studying internationalization without keeping the context in view may lead to an incomplete understanding.

From a methodological point of view, one way of studying business networks that is able to present an in-depth explanation of their complicated structures is case study analysis. In this research, the survey and the case study are integrated to obtain a rich description of the influence of firm-level entrepreneurship and business networks on the internationalization of SMEs. Thereby, it could be seen as a punctual response to Coviello and Jones (2004), who recommended combining positivist and constructivist views in IE studies to achieve a more justifying explanation. This mixed design strategy provides a rich explanation, and it is free from the deficiencies of a single design study, which relies solely on firm-level entrepreneurship or business networks to describe internationalization. Emphasizing only entrepreneurship to explain internationalization may lead to inconclusive results. Similarly, focusing on networks alone can also result in a blind analysis that ignores firms' characteristics and the role of the entrepreneur in capturing international opportunities which emerge from networks (Chetty \& Blankenburg Holm, 2000a). 


\subsection{Research Purpose and Questions}

As previously mentioned, the purpose of the research is to understand the internationalization of Iranian food and beverage SMEs through analyzing their firm-level entrepreneurship and their positions in business networks. A mixed method design is applied, starting with a survey on the relationship of firm-level entrepreneurship and internationalization, followed by an extensive qualitative and quantitative analysis using the case study approach. To get a more inclusive measure of firm-level entrepreneurship, a broad conceptualization and operationalization was implemented that combines the orientation and outcomes of entrepreneurship. All the survey variables were measured using previously validated questions, and the cases were selected in a such a way as to ensure heterogeneity of the qualitative data.

The first question of the research originated from the primary concern of the researcher, focused on the relationship between firm-level entrepreneurship and internationalization: What is the relationship of firm-level entrepreneurship and the internationalization of SMEs? This question deserves to be answered for several reasons. First, it shows weather a meaningful relationship exists between firm-level entrepreneurship and internationalization; most Iranian supportive plans for SMEs propose promoting entrepreneurship as an equivalent to enhancing internationalization to justify their immense cost. Second, it adds new insights to the literature by inspecting the relationship of entrepreneurship and internationalization in a previously ignored area and improves its overall generalizability; despite the rich theoretical foundation of IE studies, their empirical findings are somehow confusing. Third, it helps managers and practitioners to reach a more accurate prediction of SMEs' internationalization; forecasting internationalization and international performance is an important concern of managers and practitioners.

Studying the relationship of firm-level entrepreneurship and internationalization without contemplating the environmental factors which may moderate their association cannot lead to solid conclusions; therefore, a more explanatory research model consisting of environmental factors is highly advised. The environmental dimensions of dynamism and hostility are included in this research because they are frequently regarded as 
moderators in international entrepreneurship studies. Considering the moderating effect of the environment on the relationship of firm-level entrepreneurship and internationalization raises the second question of the research: What are the moderating effects of environmental dynamism and hostility on the link between firm-level entrepreneurship and the internationalization of SMEs?

Answering these questions without looking at the business networks in which companies are performing may result in a limited understanding. Actually, business interrelationships - embedded in a complex network structure - help smaller companies to overcome their internationalization barriers through accessing necessary information and complementary resources. Network structure also facilitates the IE process by increasing the probability of recognizing and realizing international business opportunities. Consequentially, exploring the role of business networks in International Entrepreneurship (IE) studies in general and in this research in particular is instructive. As discussed earlier, a case study approach is applied to answer the following question: How does the network structure influence the internationalization of entrepreneurial SMEs?

\subsection{Research Process and Thesis Structure}

This study was performed in two sequential steps, first a survey and then a case study. The results of the survey were used as a basis for conducting the case study. A fundamental question raised during a literature review that was performed to find a true measurement of firm-level entrepreneurship. This question needed to be answered before proceeding further: how should firm-level entrepreneurship be measured? There were different constructs in the literature, none of which truly represented the phenomenon. Therefore, an integrative measurement of firm-level entrepreneurship was designed that incorporated $\mathrm{EO}$ and $\mathrm{CE}$ in a four-fold model. This profile measurement of firm-level entrepreneurship classifies SMEs into four types: non-entrepreneurial, latent entrepreneurial, forced entrepreneurial, and actual entrepreneurial.

In accordance with profile-based operationalization, hypotheses were designed in a comparative manner and hierarchical regression techniques based on contrast coding were applied to test them. In disagreement with the hypotheses that predicted actual 
entrepreneurial firms as the most internationalized type, the forced entrepreneurial companies demonstrated better internationalization. Hence, it required more investigation to explain why the forced entrepreneurial companies exhibited better internationalization than actual entrepreneurial firms. To answer that, a case study including four cases, one from each category, was carried out. A counter case - an international actual entrepreneurial company - was also studied to obtain heterogeneous data about the actual entrepreneurial as the target type of the research. The second round of the review, supported by the field observations, revealed the prominent role played by the business networks in the internationalization of the forced entrepreneurial case.

To respect the standard format of a research write-up, this thesis covers the aforementioned process, but not as exactly as in the sequence that was carried out in reality. The research has been written down in five chapters. The first chapter emphasizes the major concerns and questions of the research. The literature review draws the conceptualization and definitions of applied constructs, discusses theories and the theoretical framework, and designs the hypotheses based on a review of current empirical studies. Furthermore, a brief summary of former studies, which incorporates networks, entrepreneurship, and internationalization, is presented to pave the way for a more precise analysis of the cases. Similar to almost all studies, chapter three deals with methodology, the philosophical views behind the research, and the techniques and approaches that are implemented to secure the results. Chapter four features the research analysis in two different sections: quantitative analysis that presents analytical procedures and the results of hypothesis testing, and case study analysis that briefly explains the cases, their attributes, network structure and a cross-cases analysis on the basis of network metrics. Finally, Chapter five discusses and explains the findings of the research, compares the results with similar studies in the literature, pictures the contributions, and recommends areas that should be studied more in the future.

\subsection{Research Delimitations}

The results of every study should be used with attention to its limitations. This research also has its own limitations which should be considered when applying its findings. First, 
the generalizability of the findings may be limited because of the type of firm and industry under investigation. SMEs are not just smaller versions of larger companies; they have their own unique characteristics. Also, performing the study in one country (Iran) using a single industry (the Food and Beverage Industry) could challenge the external validity of the study. Undoubtedly, every industry is influenced by peculiar forces arising from its own form of product, competition, the level of technological advancement, and governmental regulations (Robertson \& Chetty, 2000). Second, implementing perceptual measurements because of the inability to source the archival data introduces another limitation of this study. The perceptual or self-reported measures of firm-level entrepreneurship or international performance may cause some degree of bias (Anderson \& Eshima, 2013), because it may be influenced by the degree of self-confidence of respondents who overestimate or underestimate their conditions (Caruana, Ewing, \& Ramaseshan, 2002). Moreover, all data were gathered from a single informant, which may cause common method bias. Although this type of bias is discussed and controlled by implementing some ex-ante and ex-post strategies, which are thoroughly explained in Chapter Three, researchers still need to be careful about using the results.

Third, this study is a cross-sectional investigation of the companies' current conditions. This approach could not capture the dynamism of change over time. This is especially important to see how a company evolves from a non-entrepreneurial type to an actual entrepreneurial, and how this evolution affects its internationalization. A longitudinal approach can also capture the dynamics of a network and the way that networks evolve, which is also an influential issue in internationalization studies. The cross-sectional design limits the ability of performing casual inferences (Anderson \& Eshima, 2013; Lisboa, Skarmeas, \& Lages, 2011), which can offer further insights on firm-level entrepreneurship, business networks, and internationalization. Fourth, a profile model of firm-level entrepreneurship was developed and applied that synthesized two frequently accepted measurements of Entrepreneurial Orientation (EO) and Corporate Entrepreneurship (CE). Despite the logical explanation behind the model that incorporates both orientation and outcome of firm-level entrepreneurship to deliver a more reliable depiction of firm-level entrepreneurship, a question that may hit the mind is why only EO 
and CE. There are other measurements in the literature such as Stevenson and Jarillo's (1990) entrepreneurial management and Lumpkin and Dess's (1996a) five-dimensional construct of entrepreneurial orientation. They are less popular in the literature, but may raise new insight if they are included in the measurement models of firm-level entrepreneurship. In addition, profile measurement models may reduce the explanatory power of data because they remove a part of variance. This could be considered as another limitation of the profile model of firm-level entrepreneurship, but as rigorously discussed in Chapter Two, applying a profile model is reasonable answer to the challenges of existing measurements (See Chapter Two, Section Seven for an in-depth discussion).

The network data are also collected from a single informant; this is very common in the literature, but it may have limited accuracy because information from external actors was not captured. Besides, the perception of the informant regarding the strength or importance of ties was not included in the network data, which can be beneficial in this kind of investigation because of its influence on internationalization decisions, resource acquisition, new product development, and network evolution (Coviello, 2006). 


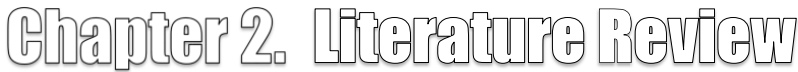

Reviewing the related literature is the first step in answering a research question. Actually, the literature helps to define and conceptualize constructs and design research hypotheses using former studies. An extensive review of existing empirical and conceptual studies was conducted to correctly define the concepts of internationalization and firm-level entrepreneurship. Internationalization is defined as a multidimensional construct that captures the international activities of companies. Firm-level entrepreneurship is also explained as both the orientation and behavior of an organization toward entrepreneurship that can be conceptualized as a profile model of EO and CE. The theoretical framework, which supports the hypotheses and justifies the case analysis, is drawn from the ResourceBased View (hereafter the RBV), Contingency Analysis, and the Network Perspective. A theoretical explanation and an accumulated conclusion on empirical studies are respectively discussed before inferring each of the hypotheses. In this way, the hypotheses are built upon a solid foundation of theoretical and empirical arguments. The last section of this chapter presents a short summary of the empirical studies, which investigate the role of the business network in the internationalization of SMEs. This summary paves the way for a more comprehensive literature review of network studies, which forms the foundation of the case analysis. 


\subsection{Internationalization}

Internationalization shapes a new form of creative destruction (Acs, Morck, \& Yeung, 2001), and becomes an unavoidable part of the contemporary business landscape (Nummela, 2004), in which international borders lose their traditional meanings (Knight, 2000) and national markets are interwoven through the exchange of services, goods, technologies and capital. To explain this crucial buzzword, a number of definitions and theories have been developed and new fields of study have emerged. As the principal part of this study, reviewing and summarizing existing definitions and theories, determining the proper conceptualization, developing an applicable theoretical framework, and positioning the study in the internationalization literature are all needful and informative.

Business internationalization is a complicated phenomenon to define, and despite the vast volume of literature on the subject, a unified definition of the concept is beyond our grasp (McAuley, 1999; Rialp \& Rialp, 2001). The lack of a universally accepted definition results in many alternative interpretations; therefore, an accurate conceptualization should be both broad and specific enough to capture the essence of the concept (Rialp \& Rialp, 2001). To arrive at a sufficiently inclusive conceptualization, going over current definitions proves very enlightening. Table 2-1 presents a very short summary of well-known definitions and their major concerns.

A simple word analysis on the major themes of these definitions uncovers a more encompassing explanation of internationalization as a process of incremental or fast involvement in international markets that increases the awareness of international influence, is encouraged by a company's network position or entrepreneurial opportunities, leads to cross-border transactions, and needs the adaptation of a firm's operation. This definition proposes a multidimensional concept that covers the scale, scope, and speed of internationalization, and incorporates the main themes of each. In this way, it includes all the advantages of the other definitions, such as comprehensiveness and inclusivity from Beamish's (1990) definition (Boojihawon, 2004; McAuley, 1999), or the unique feature of de-internationalization from Calof and Beamish's (1995) definition (Chetty \& Stangl, 2010). 
Conceptualizing internationalization as a multidimensional concept of involvement in international markets with a certain pace and performance is consistent with other studies in the field, and is required to increase the understanding and decrease the contradictions of the concept (Cavusgil \& Zou, 1994; Hadley \& Wilson, 2003; Jantunen, Puumalainen, Saarenketo, \& Kyläheiko, 2005; Sullivan, 1994, 1996).

Table 2-1: The well-known definitions of internationalization

\begin{tabular}{|c|c|c|}
\hline Author(s) & Definition & Focal Point(s) \\
\hline Johanson and Vahlne (1977, p. 23) & $\begin{array}{l}\text { "... a process in which the firms } \\
\text { gradually increase their } \\
\text { international involvement" }\end{array}$ & $\begin{array}{l}\text { Process; Incremental } \\
\text { Involvement }\end{array}$ \\
\hline Welch and Luostarinen (1988, p. 36) & $\begin{array}{l}\text { "The process of increasing } \\
\text { involvement in international } \\
\text { operations" }\end{array}$ & $\begin{array}{l}\text { Process; Incremental } \\
\text { Involvement }\end{array}$ \\
\hline $\begin{array}{l}\text { Johanson and Mattsson (1988, p. } \\
296)\end{array}$ & $\begin{array}{l}\text { "... establishes and develops } \\
\text { positions in relation to } \\
\text { counterparts in foreign } \\
\text { networks" }\end{array}$ & $\begin{array}{l}\text { Network; Network } \\
\text { Position }\end{array}$ \\
\hline $\begin{array}{l}\text { Beamish (1990), cited in Coviello } \\
\text { and McAuley (1999) and Coviello } \\
\text { and Munro (1997, p. 77) }\end{array}$ & $\begin{array}{l}\text { "The process by which firms } \\
\text { both increase their awareness of } \\
\text { the direct and indirect } \\
\text { influences of international } \\
\text { transactions on their future, and } \\
\text { establish and conduct } \\
\text { transactions with other } \\
\text { countries" }\end{array}$ & $\begin{array}{l}\text { Process; Increasing } \\
\text { Awareness and } \\
\text { Establishing } \\
\text { Transactions }\end{array}$ \\
\hline Calof and Beamish (1995, p. 116) & $\begin{array}{l}\text { "The process of adapting firms' } \\
\text { operations (strategy, structure, } \\
\text { resource, etc. to international } \\
\text { environments" }\end{array}$ & Process; Adaptation \\
\hline $\begin{array}{l}\text { Oviatt and McDougall (2005a, p. } \\
540 \text { ) }\end{array}$ & $\begin{array}{l}\text { "The discovery, enactment, } \\
\text { evaluation, and exploitation of } \\
\text { opportunities - across national } \\
\text { borders - to create future goods } \\
\text { and services" }\end{array}$ & $\begin{array}{l}\text { Entrepreneurship: } \\
\text { Fast Involvement }\end{array}$ \\
\hline
\end{tabular}

\subsection{Theories of Internationalization}

Internationalization has received widespread attention in recent years, and several theories have been developed or adapted to explain its process and dynamism. The early perspective of internationalization, introduced around 1960, relies on economics. The well-known theories that arose from this perspective are Monopolistic Advantage Theory, Internalization Theory, the Eclectic Paradigm, and the Product Life Cycle Approach. The economic perspective has been dominant for many years and has generated a large body of research (Caves, 1971; Dunning, 1988). Another standpoint is the behavioral 
(sometimes called stage) perspective, which has mainly focused on the process of internationalization as a multi-stage process; the Uppsala Model, Innovation-Related Theories, and the Holistic Approach are the most recognized models of this kind. Considering internationalization through network glasses is also a practical way of explaining the phenomenon. This view supposes internationalization as a process that starts and evolves by network interactions over time. Social Network Theory and the Industrial Network Approach are two bold applications of the network perspective in the internationalization literature. Almost all models and theories of the economic perspective are developed to explain the phenomenon in big multinational companies. Some behavioral and network theories of internationalization are applied to explain the internationalization of smaller companies as well, but they have received much criticism. A better way of explaining the phenomenon that yields a dynamic explanation is to triangulate the current theories. International entrepreneurship relies on such strategy, integrates internationalization and entrepreneurship research, and provides a persuasive approach to study the international activities of entrepreneurial SMEs.

\subsubsection{Economic Perspective}

The monopolistic theory, first presented in a $\mathrm{PhD}$ thesis by Hymer (1960), presumes the monopolistic advantage as the major driver of internationalization. It posits that a monopoly stems from the superiority of product, technology, or managerial processes, drives competitive advantage, and lets a company compete with domestic rivals, who may enjoy a better establishment in and are more familiar with the market (Rialp \& Rialp, 2001). As Caves (1971) explained, this advantage originates from superior knowledge and is fundamental to produce recognizable products. This advantage also allows a company to compete with local competitors at no extra costs. This explanation is almost similar to the logic of the RBV, which describes valuable, rare, inimitable, and non-substitutable resources as the source of competitive advantage. In fact, this theory borrows from the logic of the RBV, as it supposes the superior knowledge as a featured resource that generates international competitive advantage. 
In contrast to the monopolistic theory, the internalization theory (Buckley, 1988; Casson, 1986) relies on the reasoning of transaction cost. According to this theory, decisions have been made by taking two advantages into account: locality, which means settling business activities wherever the costs are lower; and internalization, which means internalizing actions to the point that their benefits compensate for their costs (Buckley, 1988). Whenever the cost of internalization is lower than the cost of localization (internalization advantage prevails), a company prefers to internalize activities and chooses relevant entry modes such as export. If the advantage of localization suppresses the cost of internalization (locality advantage prevails), then the company leans toward localization and selects Foreign Direct Investment (FDI) to enter a foreign market (Buckley, 1988).

The eclectic paradigm is an expanded version of the internalization, and adds the firm-specific advantage to the discussion. Thereby, the eclectic paradigm (Dunning, 1980, 1988) argues for the decision and the mode of entering a foreign market in terms of three major advantages: firm-specific (ownership), location, and internalization. The ownership advantage is related to a company itself and points out the superiorities that the company has developed in its home market, which are applicable in the international context. These superiorities are specific and built upon accumulated knowledge, intangible assets, superior technology, and distinct innovations. As described earlier, the internalization advantage represents the internal capacity of a company to manage activities within its current organizational structure. It shows the tendency of a firm to keep its ownership advantage within its own organizational structure or outsource it to other companies. The location advantage refers to industrial and production factors in a foreign country. It increases when exploiting a firm-specific advantage with indigenous resources of a host country is more profitable than exploiting it with home-country resources. The interaction of these advantages helps a company to decide about involvement in an international market and the proper mode of entry. A high ownership advantage, the cheaper and more efficient production facilities of a host country, and having more inducement to internalization leads a company to choose FDI over other entry modes. Licensing can be chosen in the same conditions in which evidence is in favor of outsourcing. In the case 
that firm-specific advantages are high but localization imposes higher costs than at-home production, export will be chosen as an appropriate entry mode.

Life cycle theory (Vernon, 1966) applies the product life cycle interpretation to explain the internationalization of an entire country. It argues that a country follows a trajectory similar to the product life cycle in its internationalization process. A country can enjoy its own specific innovations in the beginning of the cycle, when it is introduced and established; as the cycle advances, however, the comparative advantage of innovations is likely to be suppressed by the cost of production. In other words, the internationalization process, like the product life cycle, is an incremental mechanism that happens in several steps and is derived by the comparative advantage of the original country to reduce the cost. Through investigating American exporters' behavior, Vernon draws a four-step trajectory of internationalization:

1. The US exporters enjoy a monopoly.

2. Foreign countries start to produce.

3. The foreign products become competitive.

4. The US becomes an importer.

This theory is perhaps the first that looks at internationalization as an incremental process, one which takes place in several steps; therefore, it can be categorized by both the economic and stage perspectives of internationalization.

\subsubsection{Stage Perspective}

The life cycle theory builds a platform for a different type of internationalization theory, called stage models (Nummela, 2004). They look at internationalization as an incremental process which takes place in distinct but continuous steps. A step forward means engaging more resources in international markets. The gradual pattern of internationalization is attributed to (1) the lack of knowledge, especially "experiential knowledge", and (2) uncertainty associated with the decision to enter a foreign market. To be clear, these models suppose the lack of experiential knowledge and the inherent uncertainty of international activities as the causes of the incremental pattern of the internationalization 
process (Andersen, 1993). Therefore, this perspective purely relies on the behavioral view of the organization (Rialp \& Rialp, 2001), which stands upon the learning approach to describe the incremental involvement of companies in international business (Fletcher, 2008).

Different models of this perspective are actually different versions of the same story, and not substantial new contributions (McAuley, 1999). The common story behind all stage theories is their image of internationalization as a step-by-step process in which distinct phases can be distinguished. All endeavors to reach a universal view of the process, however, have failed (Nummela, 2004). In their comprehensive review of stage theories, Leonidou and Katsikeas (1996) summarized a mega three-step process of internationalization: (1) pre-engagement, (2) initial involvement, and (3) intensive participation. In the first step, companies consider internationalization as a serious strategy, so they collect and interpret relevant information and gradually become more interested in internationalization. In the second step, they engage in occasional export activities to test their strategies in practice and decide to increase or decrease their involvement in international markets. In the third step, international activities become a regular action, and the firms engage more resources and increase the scale and scope of their internationalization.

The behavioral perspective of internationalization has received significant attention. For about 40 years, many researchers utilized this perspective to explain internationalization (Leonidou \& Katsikeas, 1996). Nevertheless, it has also been criticized (e.g. Andersen, 1993) for (1) neglecting the role of context or network as a way to access external resources (Holmlund \& Kock, 1998; Madsen \& Servais, 1997), and (2) for its silence or inability to describe the causes of moving forward in the step-wise process of internationalization (Rialp \& Rialp, 2001). Actually, stage models are deterministic and adopt an objectivist view of human nature, which is not able to present a dynamic picture of internationalization (Nummela, 2004).

Three models of internationalization have proven to be the most popular: The Uppsala Model (U-model), the Innovation-Related Model (I-model), and the Holistic Approach. While the first two models have mainly focused on the outward pattern of 
internationalization, the third does not limit it to outward activities, and defines internationalization as an inclusive process including both "inward" and "outward" activities (Welch \& Luostarinen, 1988). The U-model counts the lack of knowledge and resources on the one hand, and the uncertainty of decisions and outcomes on the other, as the principal obstacles of internationalization (Johanson \& Wiedersheim-Paul, 1975). To overcome these obstacles and to reduce the uncertainty associated with international activities, companies move forward in an incremental process of learning and resource commitment. This sequence is known as the "establishment chain", and the dynamic mechanism behind that is called "psychic distance" (Johanson \& Vahlne, 1977, 1990). The establishment chain - which consists of the four distinct stages of "no regular export, independent representative (agent), sales subsidiary, [and] production" (Johanson \& Vahlne, 1977, p. 24) - represents the process, and the psychic distance shows the place to start. In other words, companies start from markets with lower psychic distance, which share more similarities with their home markets.

The U-model describes internationalization as a dynamic process of interaction between the knowledge of markets and the commitment of resources. It has two aspects, the "state aspect", and the "change aspect". The state aspect deals with obtaining market knowledge and making decisions to increase or decrease commitment, while the change aspect shows the real act of increasing or decreasing the commitment of resources. This model basically stands on the behavioral perspective and implements the logic of learning theory to explain internationalization. It distinguishes general knowledge, which is transferable, from experiential knowledge, which is acquired through being involved in international activities. The decision about the amount of resources to be committed is mainly made based on the experiential knowledge. Therefore, knowledge and learning play a vital role in both the process and the success of internationalization. This model is criticized for being inconsistent with the real behavior of companies, especially in regard to psychic distance (Andersen, 1993).

I-models are another stream of process theories of internationalization (e.g. Bilkey, 1978; Reid, 1981). They describe each stage of internationalization as an innovation, consider internationalization similar to the product adoption process (Bilkey, 1978), and 
list two types of motivation for international involvement: "push" and "pull" factors. Push factors are external powers that force companies to extend their activities beyond their national borders, while pull factors are internal elements that encourage companies to increase their international activities. I-models also look at internationalization from the behavioral perspective, and count individual learning and top managers as the major aspects of the process (Andersson, 2000).

All the theories that have been discussed thus far presume internationalization as an outward operation. The holistic approach (Welch \& Luostarinen, 1988) adopts a wider perspective, however, and defines internationalization as an "inward-outward" process in which the growth obtained from inward operations acts as a basis for the subsequent outward activities. Inward operations (e.g. import and inward licensing) increase the knowledge of companies about foreign markets and encourage them to become involved in later outward activities (e.g. export, outward licensing, and FDI). The holistic approach was the first theory that really paid attention to the direction of the process, and described inward internationalization as a way to acquire experiential knowledge. The concepts of de- or re-internationalization were presented as mechanisms to explain the forwardbackward trajectory of the internationalization process, and business distance - a similar concept to psychic distance - was applied to explain how companies select their target markets. Fletcher (2001) criticized the learning, contingency, and network approaches due to their limited dynamism, and proposed a complex holistic theory which he claimed is able to capture the dynamics of international behavior. In his model, inward and outward activities are connected through strategic alliances, cooperative manufacturing, and countertrade, and are moderated by internal and external environments. Actually, Fletcher's holistic model was a mixture of contingency analysis, Welch and Luostarinen's inward-outward approach, and interlinking strategies that bridge inward and outward operations.

\subsubsection{Network Perspective}

The network perspective looks at internationalization from the relational view, and describes it as a sequential development of relationships with foreign actors (Francis \& 
Collins-Dodd, 2000; Styles \& Ambler, 1994). A business network could be a collection of relationships between all of the business actors such as brands, customers, marketing companies, advertisers, market research agencies, and all other influential players in the supply chain (Styles \& Ambler, 1994). This perspective defines the network position as the main driver of internationalization (Boojihawon, 2004; Johanson \& Mattsson, 1988), and focuses on strategies that are applied to strengthen and monitor that position. This perspective is applied by researchers in different fields, but finding a universally accepted network theory of internationalization is difficult (Nummela, 2004). Generally, a network includes both formal and informal aspects (McAuley, 1999) and is considered to be a powerful tool to explain internationalization, because internationalization can be seen as a network activity, which deals with establishing, maintaining, and developing relationships with various actors in international markets.

Social network theory (SNT) (Coleman, 1988; Granovetter, 1985) is one of the few theories that can be used in different levels of analysis such as individual, organization, and even country (Pitt, van der Merwe, Berthon, Salehi-Sangari, \& Caruana, 2006). SNT defines a network as a set of objects (sometimes called actors, nodes, etc.) and their relationships (sometimes called ties, links, etc.) (Pitt et al., 2006) in which: (1) actors and their actions have interdependence, not independence; (2) links between actors show the flow of tangible or intangible resources; and (3) the structure is a lasting pattern of relations that encourages or discourages actions (Wasserman \& Faust, 1994). The main goal of SNT is to study the features of network structure, for example weak or strong ties (Granovetter, 1985), social capital (Coleman, 1988), and so forth, through mapping and professional analysis techniques (Fletcher, 2008; Wasserman \& Faust, 1994). The business literature extended SNT beyond social science to study business subjects (Rialp \& Rialp, 2001; Zain \& Ng, 2006). Actually, business always takes place in a network context with a set of actors that are linked together (Rialp \& Rialp, 2001). Therefore, from a SNT point of view, a business network is defined as;

A set of two or more connected business relationships, in which each exchange relation is between business firms that are conceptualized as collective actors (Chetty \& Blankenburg Holm, 2000b, p. 79). 
A well-known theory that applies network position to explain internationalization is Johanson and Mattsson's (1988) network model. It describes internationalization as the process of creating and developing a network of relationships with international companies. Internationalization is an evolutionary process that is conducted in three sequential stages: market expansion, market penetration, and market integration. In this model, network position is determined based on the degree of internationalization of a firm and the degree of internationalization of the network (market). Therefore, companies are classified into four categories: Early Starter, Lonely International, Late International, and International Among Others. The early international is a domestic company that works with local suppliers, competitors, and cooperators, while the lonely international and late international are international firms that perform in local and international networks, respectively. Finally, the international among others type is an international company performing in an international market. This model was operationalized and tested by Hadley and Wilson (2003). They found that internationalization knowledge is significantly related to market diversity. It means a diversified network has greater potential to equip companies with the required knowledge for internationalization. Fletcher and Barrett (2001) ran another study using this model and empirically confirmed the three-step sequential process of international expansion, international penetration and international integration. They also found the environment and atmosphere of interaction to be an influential factor that should be considered. Johanson and Mattsson's model is criticized for ignoring the firm's and decision makers' characteristics and for the overlapping of proposed categories (Chetty \& Blankenburg Holm, 2000b).

Industrial network studies (Hakansson, 1982; Hakansson \& Snehota, 1989), mainly performed by the Industrial Marketing and Purchasing (IMP) Group, have concentrated on business networks and include actors, resources and activities in their analysis. Among the many theories and models from the IMP group, the Interaction Model (Hakansson, 1982), the Actors, Resources, and Activities (ARA) Model (Hakansson \& Johanson, 1992), and the Network Embeddedness Model (Halinen \& Törnroos, 1998) have found the most popularity in internationalization studies (Fletcher, 2008). The interaction model discuses actors, environment and atmosphere as factors that influence 
the buyer-supplier relationship. Actors in the ARA model are objects which control activities through resources. In other words, actors develop and maintain relationships through an exchange process that creates, maintains, and strengthens the connections between firms. This model depicts a more complex picture of interactions (Nummela, 2004) and implements a complicated analysis of activity links, resource ties and actor bonds (Hakansson \& Johanson, 1992). From the ARA model point of view, the function of a business relationship is to interlink the activities in a way that helps actors get the best value from their resources. The network embeddedness model views companies as embedded entities in bigger networks, and describes six different aspects of their embeddedness: temporal (the effect of a company's history), spatial (the role of location), social, market, political, and technological. From network embeddedness point of view, simultaneous analysis of all aspects is needed to understand the organizational behavior.

In summary, the network perspective of business-related phenomena originates from social network studies, and business researchers have implemented those techniques to study business networks (Rialp \& Rialp, 2001). According to the network perspective, researchers should look beyond the firms' characteristics, or even environmental factors, to the networks that companies are embedded in if they want to obtain a realistic explanation of business events (Cook \& Emerson, 1978; Halinen \& Törnroos, 1998). Networks are studied in different contexts and at different levels of analysis, and therefore finding a universally accepted network theory is hardly possible (Nummela, 2004). "North American" and "Nordic" schools of thought proposed their own view of a network. While the former has mainly focused on analyzing the structure of a network using SNA techniques, the latter, focused on the network evolution process, applies a more complicated view of a network including actors, resources, and activities (for more detail on their differences, see Hu and Stanton (2011, p. 535) and Tikkanen (1998, pp. 111-115)).

\subsubsection{International Entrepreneurship}

A number of studies apply the stage perspective to explain SMEs' internationalization, but criticism around them is vast. SMEs do not show the determining non-reversible process proposed by the stage perspective (Andersen, 1993; Coviello \& Munro, 1997). In 
addition, stage models ignore the interaction between firms and actors in the internationalization process (Coviello \& Munro, 1997). Although the network perspective seems a better fit to describe how smaller firms can overcome their resource limitations (Francis \& Collins-Dodd, 2000; Lu \& Beamish, 2001), and how they select their foreign markets and entry modes (Bell, 1995), relying only on the network perspective may also lead to a limited understanding. In other words, since developing business networks does not just depend on physical resources, and since it benefits most from companies' entrepreneurial traits, social capital, and so on (Etemad, 2004), trusting the network perspective alone to explain the internationalization of entrepreneurial firms could result in a blurred and static image, one which does not take other important aspects into account. All in all, there is not a single theory that could be able to fully explain the internationalization of entrepreneurial companies. International Entrepreneurship (IE) as a new field of study developed to bridge the gap by triangulating the current theories of internationalization.

IE was first introduced as a concept or a field of study in 1989 (Covin \& Miller, 2013), and by the mid-1990s received much attention, especially from international business researchers (Boojihawon, 2004). Similar to many other entrepreneurship concepts, to date a consensus on its definition has yet to be reached. Mcdougall (1989, p. 387), in an early study of IE, defined the concept as;

The development of international new ventures or start-ups that, from their inception, engage in international business, thus viewing their operating domain as international from the initial stages of the firm's operation.

Four years later, Zahra (1993a, p. 9) extended the concept to firm-level entrepreneurship and defined IE as "the study of the nature and consequences of a firm's risk-taking behaviors as it ventures into international markets". In accordance with Zahra's concept stretching, , McDougall and Oviatt (2000, p. 903) modified their definition of IE as "a combination of innovative, proactive, and risk-seeking behavior that crosses national borders and is intended to create value in organization". They clearly defined the field as an intersection of entrepreneurship (typically firm-level entrepreneurship) and 
internationalization. Later, definitions such as those by Zahra and George (2002) and Oviatt and McDougall (2005a) changed their focus from firm-level entrepreneurship to entrepreneurial opportunities. For example, Oviatt and McDougall (2005a, p. 540) defined international entrepreneurship as "the discovery, enactment, evaluation, and exploitation of opportunities - across national borders - to create future goods and services”. Despite all the attempts to find a unified definition for the concept, it is still in a state of evolution.

To be successful in international markets, companies need to recognize business opportunities and develop practical ideas to exploit them. They should pay special attention to their access to required knowledge and necessary resources when they are developing ideas (Nummela, 2004). In contrast to traditional theories, which consider experiential knowledge as the foundation of resource commitment, IE is more dependent on entrepreneurial knowledge to seek international opportunities (Zahra, 2005; Zhou, Barnes, \& Lu, 2009). Generally, IE is based on two major types of research: (1) the studies that compare the firm-level entrepreneurial behaviors of different cultures and countries, and (2) the research on entrepreneurial behaviors of companies that move beyond their domestic boarders to international markets (McDougall \& Oviatt, 2000; Oviatt \& McDougall, 2005a). In its early definitions (e.g. McDougall \& Oviatt, 2000; Zahra, 1993a), IE explicitly concentrated on firm-level entrepreneurship, but more recent definitions have focused on entrepreneurial opportunities instead. Nonetheless, the centrality of firm-level entrepreneurship is widely acknowledged (Covin \& Miller, 2013), and it can be meaningfully extended into the field (Slevin \& Terjesen, 2011).

From a philosophical point of view, IE believes in some kind of pragmatism and researchers are advised to incorporate different theories in explaining the internationalization of entrepreneurial firms (Jones, 1999). But in reality, and similar to most international studies (Urbano \& Turró, 2013), IE research ignores this recommendation and does not follow a solid theoretical framework and methodological direction (Boojihawon, 2004). In their review study, Keupp and Gassmann (2009) showed that IE studies suffer from the lack of a theoretical framework. To avoid this problem, any research in the field should clearly define its theoretical framework, and it is better to rely 
upon triangulations of theories to explain complicated subjects such as entrepreneurship and internationalization.

\subsection{Theoretical Framework of the Research}

Table 2-2 summarizes the internationalization theories that were discussed in terms of their view (the overall logic behind their interpretations), their focus (the primary subject they aim to explain), and the important challenges and criticism around them. Economic theories look at internationalization through the glasses of the RBV, transaction cost theory, or the life cycle trajectory. They mainly explain how a multinational company chooses a proper entry mode or describe the internationalization process of an entire country. The economic perspective pays less attention to smaller companies, and is better used when the internationalization of big companies or a whole nation has been studied. Stage models are occasionally implemented to explain the internationalization of smaller firms, but they were originally developed in Multinational Enterprise (MNE) research. These models are especially powerful in describing the export behavior of SMEs in the initial stage of their internationalization process (Rialp \& Rialp, 2001).

The network view offers a more robust explanation of why and how the internationalization of small entrepreneurial companies occurs (Coviello \& Munro, 1995). In fact, formal and informal network relationships drive, facilitate, and settle the internationalization of SMEs (Coviello \& Munro, 1997). This perspective provides a complementary explanation to other theories which do not account for the influence of relationships (Boojihawon, 2004). International entrepreneurship, the last perspective on internationalization, chooses entrepreneurship as the cornerstone to explain the phenomenon. It supposes a bold connection between entrepreneurship and internationalization, and triangulates different theories to discuss the scale, scope and speed of internationalization.

The purpose of this study is to investigate the relationship of firm-level entrepreneurship and the internationalization of SMEs. The configurational approach is recommended as a method that holds great promise for performing these kinds of studies (Covin \& Lumpkin, 2011; Wiklund \& Shepherd, 2005). Wiklund and Shepherd (2005) 
enlisted three different ways of study the relationship of firm-level entrepreneurship and performance - the universal, contingency, and configurational approaches.

Table 2-2: The perspectives and theories of Internationalization

\begin{tabular}{|c|c|c|c|c|}
\hline Perspective & Theory & View & Focus & Criticism \\
\hline \multirow{4}{*}{ Economic } & $\begin{array}{l}\text { Monopoly } \\
\text { Advantage Theory }\end{array}$ & RB V & $\begin{array}{l}\text { Performance } \\
\text { (MNEs) }\end{array}$ & \multirow{4}{*}{$\begin{array}{l}\text { 1. Emphasizing more on } \\
\text { entry modes rather than the } \\
\text { whole process of } \\
\text { internationalization. } \\
\text { 2. Focusing on large } \\
\text { multinational companies. }\end{array}$} \\
\hline & $\begin{array}{l}\text { Internalization } \\
\text { Theory }\end{array}$ & $\begin{array}{c}\text { Transaction } \\
\text { Cost } \\
\end{array}$ & $\begin{array}{l}\text { Entry Mode } \\
(\text { MNEs })\end{array}$ & \\
\hline & Eclectic Paradigm & $\begin{array}{c}\text { Transaction } \\
\text { Cost }\end{array}$ & $\begin{array}{l}\text { Entry Mode } \\
(\text { MNEs })\end{array}$ & \\
\hline & \multirow{2}{*}{ Life Cycle Theory } & \multirow{2}{*}{ Life Cycle } & \multirow{2}{*}{$\begin{array}{c}\text { Process } \\
\text { (Countries) }\end{array}$} & \\
\hline \multirow{4}{*}{ Stage } & & & & \multirow{4}{*}{$\begin{array}{l}\text { 1. Neglecting the role of } \\
\text { context and network as a } \\
\text { way to access external } \\
\text { resources. } \\
\text { 2. Its inability to explain } \\
\text { what triggers and supports } \\
\text { the progress of } \\
\text { internationalization. } \\
\text { 3. Having a deterministic } \\
\text { and objective view of } \\
\text { human behavior. } \\
\text { 4. Inconsistency between } \\
\text { theory and reality. }\end{array}$} \\
\hline & Uppsala Model & Behavioral & $\begin{array}{c}\text { Process } \\
\text { (MNEs and } \\
\text { SMEs) }\end{array}$ & \\
\hline & $\begin{array}{l}\text { Innovation-Related } \\
\text { Models }\end{array}$ & Behavioral & $\begin{array}{c}\text { Process } \\
\text { (MNEs and } \\
\text { SMEs) }\end{array}$ & \\
\hline & $\begin{array}{l}\text { Welch and } \\
\text { Loustarinen's } \\
\text { Approach } \\
\text { Fletcher's Holistic } \\
\text { Approach }\end{array}$ & $\begin{array}{l}\text { Behavioral, } \\
\text { Contingency }\end{array}$ & $\begin{array}{c}\text { Process } \\
\text { (MNEs and } \\
\text { SMEs) }\end{array}$ & \\
\hline \multirow{2}{*}{ Network } & $\begin{array}{l}\text { Social Network } \\
\text { Theory }\end{array}$ & Relational & $\begin{array}{l}\text { Decision, } \\
\text { Performance } \\
\text { (MNEs and } \\
\text { SMEs) }\end{array}$ & \multirow{2}{*}{$\begin{array}{l}\text { 1. They ignore the role of } \\
\text { top managers and firms, } \\
\text { characteristics. } \\
\text { 2. The lack of a unified } \\
\text { accepted theory. } \\
\text { 3. The limited dynamism to } \\
\text { explain the } \\
\text { internationalization process. }\end{array}$} \\
\hline & $\begin{array}{l}\text { Industrial Networks } \\
\text { (IMP Group) }\end{array}$ & Relational & $\begin{array}{l}\text { Decision, } \\
\text { Performance } \\
\text { (MNEs and } \\
\text { SMEs) }\end{array}$ & \\
\hline IE & $\begin{array}{l}\text { Theory } \\
\text { Triangulation }\end{array}$ & Mixed & $\begin{array}{l}\text { Scale, Scope, } \\
\text { Speed (MNEs } \\
\text { and SMEs) }\end{array}$ & $\begin{array}{l}\text { 1.Lack of solid theoretical } \\
\text { framework. }\end{array}$ \\
\hline
\end{tabular}

The universal approach supposes that firm-level entrepreneurship is universally beneficial, while the contingency models add the effect of external environment and focus on a two-way interaction of firm-level entrepreneurship and external environment. The configurational approach adopts a wider perspective and believes that specific and theoretically relevant elements of strategy, structure, process, and environment cluster together to build an optimized configuration (Anderson \& Eshima, 2013; Wiklund \& Shepherd, 2005). Consequently, it investigates the alignment of more than two elements 
and can provide a deeper understanding of the link between firm-level entrepreneurship and performance (Wiklund \& Shepherd, 2005) or internationalization.

As mentioned, this study has focused on the association of firm-level entrepreneurship and internationalization, therefore, it is classified as an IE study. To avoid the aforementioned theoretical problems of this kind of research, defining a solid and reliable theoretical framework is required. Consequently, the RBV, contingency analysis, and the network perspective are triangulated to form the theoretical framework. This framework is able to deliver a dynamic picture of SMEs' internationalization and is in consort with the nature of international entrepreneurship because: (1) IE aims at theory triangulation to explain the internationalization of entrepreneurial firms, (2) theory triangulation is a better fit with the configurational approach as an enriching method to study firm-level entrepreneurship, (3) theory triangulation can better justify the multidimensional conceptualization of internationalization, and (4) researchers are advised to triangulate theories when they are studying complicated phenomena such as entrepreneurship or internationalization (Coviello \& Jones, 2004; Coviello \& McAuley, 1999; Crick \& Spence, 2005; Ripolles, Blesa, \& Roig, 2010).

Selecting appropriate theories depends on what the research aims to explain. The transaction cost approach does not adequately address the speed of internationalization (Törnroos, Freeman, Medlin, \& Akademi, 2012), life cycle theory and stage models have mainly focused on the process, and all are developed to recount the internationalization of MNEs; therefore, they do not fit with the purpose of this study. Firm-level entrepreneurship can be seen as a valuable, rare, inimitable, and non-substitutable resource. SMEs possess a better position than larger firms in terms of this advantageous resource because of their more unified orientation and better flexibility to implement entrepreneurial strategies. Although this resource can fundamentally contribute to internationalization, it cannot explain the phenomenon entirely because the internationalization of small firms is influenced by different factors. It is very likely that the relationship of firm-level entrepreneurship and internationalization has been moderated by environmental factors. Thereby, a contingency analysis is inspiring (Loane $\&$ Bell, 2006) and recommended to draw a more accurate explanation (Dess, Pinkham, \& 
Yang, 2011). In short, a combination of the RBV and contingency analysis can present a more acceptable picture of the conditional relationship of firm-level entrepreneurship and internationalization.

Despite all the benefit of the RBV and contingency analysis, they are not able to deliver a holistic explanation of the phenomenon. A quick look at the literature reveals the increasing number of studies that are using the network perspective (Coviello \& McAuley, 1999) in conjunction with the RBV to explain internationalization, as it yields a rich argument on the decision and the speed to engage in foreign markets (Coviello \& Munro, 1995; Coviello \& Munro, 1997; Jones, 1999). The network perspective is also beneficial in describing firm-level entrepreneurship activities and highly recommended to include in relevant studies (Miller, 2011). Generally, the RBV and the network perspective complement each other in explaining international expansion and success (Freeman \& Cavusgil, 2007) and are mutually compatible; the former counts advantageous resources as the origin of heterogeneity, and the latter explains the nature and origin of those resources (Hayton, Hornsby, \& Bloodgood, 2013).

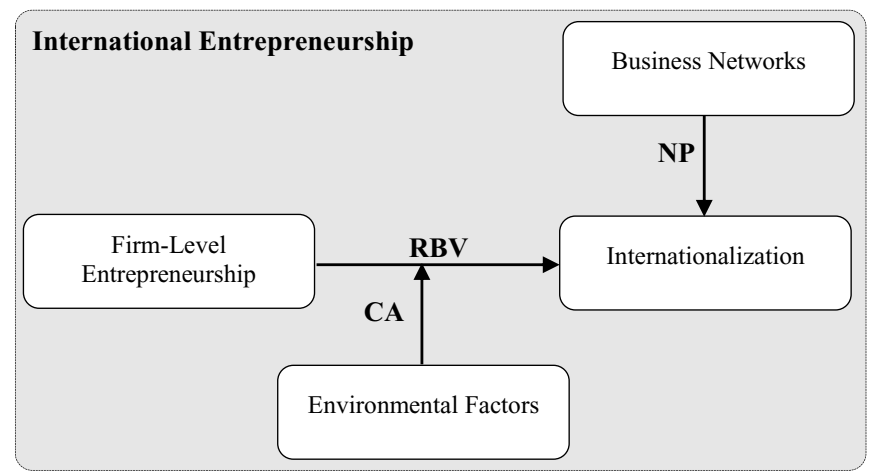

Figure 2-1: Theoretical framework of the research

In IE studies, the RBV describes the internal factors behind the superior performance of entrepreneurial companies, while the network perspective illustrates the role of other companies in their internationalization (Young, Dimitratos, \& Dana, 2003). There are several studies which incorporate the resource-based view, the network perspective (Freeman \& Cavusgil, 2007), and even contingency analysis (Boso, Story, 
Cadogan, Micevski, \& Kadic-Maglajlic, 2013) to investigate the internationalization of SMEs. This research also integrates these theories to obtain a deeper understanding of firm-level entrepreneurship and internationalization. Figure 2-1 illustrates the position and the theoretical framework of the study.

This theoretical framework could be regarded as a reply to Miller's (2011) call to invite entrepreneurship researchers to embrace the fundamental theories of other disciplines. It is also in line with Freeman and Cavusgil's (2007) recommendation to mix existing theories for studying the internationalization of small entrepreneurial firms.

The RBV was developed by strategic management researchers (Barney, 1991; Barney, Wright, \& Ketchen, 2001; conner, 1991; Grant, 1991). It has deep roots in Penrose's (1959) theory of growth, which was the first theory to describe internal characteristics as the source of sustainable growth (Huang \& Wang, 2011). The RBV is one of the most popular theories to explain why companies show different degrees of performance (Lisboa et al., 2011). It discusses the heterogeneity of resources as the source of sustainable competitive advantage and superior performance. Resource heterogeneity means the asymmetric distribution of resources among companies. From the RBV standpoint, a company is a combination of heterogeneous tangible and intangible resources which determine its capacity to supply demanded products and services (Barney et al., 2001; Grant, 1991). The first thing that should be understood in order to grasp the theory is the essence of what a resource really is. Resources are assets, capabilities, processes, attributes, information, and knowledge that enable a company to develop strategies that lead to sustain competitive advantage (Barney et al., 2001). Therefore, the RBV does not limit resources to physical assets, but includes all attributes, characteristics, capabilities, and processes. The RBV relies on the heterogeneity of resources and argues that companies do not have access to same resources; thus, they need to achieve and maintain an advantageous position in regard to featured resources to keep a profitable market position (conner, 1991). There is no consensus on the characteristics of featured resources; while Barney (1991) counted valuableness, rareness, imitability and having no substitutes as desired features, Grant (1991) listed durability, transparency, transferability, and replicability. 
The resource-based view offers an inclusive framework to inquire about business activities (Loane \& Bell, 2006); explains how firm-level attributes such as size, competence and strategies can influence the export performance (Francis \& Collins-Dodd, 2000); and is a popular framework for which to study the internationalization of SMEs (Young, Dimitratos, \& Dana, 2003). It is also frequently used in start-up entrepreneurship research. Unfortunately, the literature on firm-level entrepreneurship suffers from the lack of a solid theoretical framework, although in recent years, increasing attention has been placed on the RBV as a proper theoretical framework for this kind of research (Urbano \& Turró, 2013). Based on the RBV explanation, firm-level entrepreneurship could be regarded as an intangible resource (Lee, Lee, \& Pennings, 2001), an organizational asset (Adonisi \& Van Wyk, 2012), a strategic posture (Anderson \& Eshima, 2013), or a capability to combine (Alvarez \& Busenitz, 2001), acquire (Huang \& Wang, 2011), and facilitate the effect of resources (Wiklund \& Shepherd, 2003). It is a valuable, rare, imperfectly imitable, and non-substitutable (Alvarez \& Busenitz, 2001; Anderson \& Eshima, 2013; Wiklund \& Shepherd, 2003, 2011) resource that enables a company to discover and exploit international opportunities ahead of its rivals.

Contingency analysis - first used in leadership research - is a major approach to study the effect of environmental factors on business activities. A number of internationalization studies have applied this mechanism and developed fine-grained models of the phenomenon (e.g. Cavusgil \& Zou, 1994; Yeoh \& Jeong, 1995). Those models look at internationalization as a response to circumstances and opportunities (Fletcher, 2008; Robertson \& Chetty, 2000), and believe there is no single strategy appropriate for all conditions (Ruekert, Walker, \& Roering, 1985). Contingency analysis assumes actions as logical reactions to environmental conditions, and assign a determinant role to environmental factors in designing and executing business strategies. This type of analysis can provide a deeper understanding of complex events such as entrepreneurship (Chandler \& Lyon, 2001) and internationalization (Robertson \& Chetty, 2000). 


\subsection{Firm-Level Entrepreneurship}

About 16 years ago, in the beginning of their seminal paper, Zahra, Jennings, and Kuratko (1999) described firm-level entrepreneurship as a long-standing but growing area of research. Today, after much debate in the entrepreneurship and management literature, firm-level entrepreneurship still remains an interesting and growing body of research. For a long time, entrepreneurship studies had focused on start-up entrepreneurs and studying their characteristics, behaviors and their processes of starting a new business (Zahra, Randerson, \& Fayolle, 2013a). Peterson and Berger (1971) changed this direction by introducing and explaining the entrepreneurship of established companies. They focused on the music industry and sought to define the necessary conditions and proper strategies for performing and developing firm-level entrepreneurial activities. Peterson and Berger's work extremely influenced the field, but it was Miller's (1983) paper published in Management Science, "The Correlates of Entrepreneurship in Three Types of Firms", that first introduced a popular measurement of firm-level entrepreneurship and attracted much research to the filed.

Surprisingly, Miller's major intention was not to define and operationalize a measurement of firm-level entrepreneurship, but he did intend to study the management styles and strategies which can promote entrepreneurial activities in existing companies. Miller's construct of entrepreneurial posture was later refined, validated and republished by Covin and Slevin $(1989,1991)$ and became more popular than all other constructs of entrepreneurship. Burgelman's (1983, 1984) study of corporate venturing and Pinchot's (1986) work on intrapreneurship, which mainly had focused on both formal and informal aspects of firm-level entrepreneurial activities, spurred on the field even more. In 1990, the Strategic Management Journal published a special issue on the subject and officially introduced firm-level entrepreneurship as an emerging but attractive field of research in the entrepreneurship literature.

The positive relationship between firm-level entrepreneurship and corporate performance supported in the early research encouraged researchers to investigate the phenomenon in different industries and contexts. However, subsequent studies showed that the beneficial influence of firm-level entrepreneurship is not limited to large 
corporations, and that SMEs can also benefit from those opportune outcomes (Antoncic $\&$ Hisrich, 2004). Still, there is not a consensus about the universal benefits of firm-level entrepreneurship. The main reason for this disagreement is the ambiguity surrounding the nature of the construct (Covin \& Miles, 1999). Without having a clear and well-defined concept of the phenomenon, discussing its benefits can be misleading (Dess, Lumpkin, \& McGee, 1999). Therefore, the first step is to define and conceptualize the concept in a clear manner.

Unfortunately, a considerable number of firm-level entrepreneurship studies suffer from a major definitional problem (Jennings \& Lumpkin, 1989). This problem causes: (1) confusion about what is really related to the concept, and how it is differentiated from other existing constructs; (2) the inclusion of inexact indicators because the focal construct is not clearly defined; and (3) the implausible conclusions about its relations with other variables (MacKenzie, Podsakoff, \& Podsakoff, 2011). Actually, defining a construct clearly is an necessary element of construct validity and is deployed to evaluate the appropriateness of the construct in a given context (George \& Marino, 2011). To have a well-defined concept and avoid the problems of poor conceptualization, researchers should respect nominal meaning (Covin \& Miller, 2013) and identify, define and distinguish the indicators in a clear manner. Nominal meaning is the;

... meaning assigned without reference to empirical information. That is, it is the inherent definitional nature of the construct that forms the basis for hypothesizing linkages with other constructs, developing observable indicators, and so forth" (Howell, Breivik, \& Wilcox, 2007, p. 207).

Stated differently, the conceptualization should originate from nominal meaning and theoretical discussion, and it is not advised to conceptualize a construct based on the results of an empirical technique such as factor analysis (Covin \& Miller, 2013).

Researchers have used different labels for firm-level entrepreneurship (Zahra et al., 1999), for instance entrepreneurship (Miller, 1983), entrepreneurial posture (Covin \& Slevin, 1991), entrepreneurial orientation (Lumpkin \& Dess, 1996a; Wiklund, 1999), entrepreneurial style (Naman \& Slevin, 1993), entrepreneurial management (Stevenson \& Jarillo, 1990), entrepreneurial strategy making (Dess, Lumpkin, \& Covin, 1997), corporate 
entrepreneurship (Burgelman, 1983; Peterson \& Berger, 1971; Zahra, 1991, 1993b, 1996a; Zahra \& Covin, 1995), and intrapreneurship (Antoncic \& Hisrich, 2001, 2003). These labels indicate different definitions and conceptualizations and should not be applied interchangeably. Covin and Miles (1999) classified them into three major groups: (1) new entry (e.g. CE), (2) employees as entrepreneurs (e.g. Intrapreneurship), and (3) entrepreneurship as an entire philosophy or orientation (e.g. EO, EM, and so forth). These three groups of concepts represent the various dimensions (Covin \& Miles, 1999), and none of them draws a holistic picture of firm-level entrepreneurship. In this research, firmlevel entrepreneurship is defined in a way that respects the nominal meaning, includes clear-cut indicators, and is broad enough to cover the whole issue.

Firm-level entrepreneurship is sometimes defined as a unique field of research, but the essential nature of entrepreneurship is universal (Morris, Kuratko, \& Covin, 2010). The commonalities between firm-level and start-up entrepreneurship allow researchers to learn a great deal from existing concepts and studies of start-up entrepreneurship (Morris et al., 2010). Start-up entrepreneurship is an older area of research with more established conceptualizations and definitions; therefore, it can be helpful to look at both areas of research to properly conceptualize firm-level entrepreneurship.

Many studies have attempted to present a universal definition of entrepreneurship one which effectively summarizes all existing definitions. Morris et al. (2008) performed a keyword analysis and came up with 18 common keywords and themes related to entrepreneurship. The most common themes were creation of wealth, creation of enterprise, creation of innovation, creation of change, creation of employment, creation of value, and creation of growth. They propounded Stevenson and Jarrillo-Mossi's (1986) definition as a fairly comprehensive one which includes all core components. Stevenson and Jarrillo defined entrepreneurship as “... A process of creating value by bringing together a unique package of resources to exploit an opportunity" (p. 10). This definition was expanded by Shane and Venkataraman (2000) to include opportunity exploration and exploitation as the most recognizable components of the entrepreneurship process. Defining entrepreneurship as the process of exploration and exploitation of opportunities enabled researchers to extend the conceptual domain of entrepreneurship beyond the start- 
up entrepreneurs to firm-level entrepreneurship. In keeping with this, firm-level entrepreneurship is defined as the process of exploration and exploitation of entrepreneurial opportunity that could lead to the creation of value in established companies. This definition links firm-level entrepreneurship to the new conceptualization of international entrepreneurship, and reinforces the positioning of the study. Oviatt and McDougall (2005a, p. 540) declared that;

... adopting a new definition of international entrepreneurship that relies to a large extent on Shane and Venkataraman's (2000) definition of entrepreneurship is appropriate at this time.

It is also in accordance with Eggers, Kraus, Hughes, Laraway, and Snycerski (2013, p. 527), who defined firm- level entrepreneurship as;

“... identifying market opportunities that competitors have not yet recognized or that are under-exploited, and creating a unique set of resources to exploit them.

As previously mentioned, there are three common themes to conceptualize firmlevel entrepreneurship. The first is intrapreneurship (employees as entrepreneurs). Intrapreneurship focuses on the personal characteristics of intrapreneurs (Antoncic, Cardon, \& Hisrich, 2004) and the way that they perform entrepreneurial activities in a given company. This conceptualization is not in line with the proposed definition of firmlevel entrepreneurship. This study defined firm-level entrepreneurship as an entire organizational event that is not limited to some select people in a company. From a nominal meaning point of view, intrapreneurship separates the firm-level entrepreneurship as a unique area of research, while it is just an application of the universal concepts of entrepreneurship in a new context (Morris et al., 2010).

The second theme is entrepreneurship as an entire philosophy or orientation. EO and entrepreneurial management are two major conceptualizations of this category. Entrepreneurial management - defined by Stevenson and Jarillo (1990) and operationalized by Brown, Davidsson, and Wiklund (2001) - obtained less popularity (Gartner \& Baker, 2010) in practice. Stevenson's studies are mainly cited for presenting 
an opportunity-based definition of entrepreneurship rather than their achievement in developing a practical measurement of firm-level entrepreneurship (Kuhn et al. 2010). In contrast, EO has earned a lot of popularity and has become the most approved measurement of firm-level entrepreneurship. Conceptualizing the phenomenon based on EO alone, however, does not draw a holistic image because it only covers the attitudinal aspect, while "entrepreneurship has attitudinal and behavioral components" (Morris, 1998, p. 17). Also relying solely on EO is not in agreement with the suggested definition of the study, since EO does not guarantee the exploitation of opportunities.

The third theme is entrepreneurship as new entries. This theme takes an outputbased view and focuses on the behavioral component of firm-level entrepreneurship. CE is a popular conceptualization of this category. Just as EO, it only focuses on one dimension of entrepreneurship, the behavioral component. But in contrast to EO, which builds upon the exploration aspect of entrepreneurship, CE concentrates on the exploitation and is not very concerned about the exploration. Therefore, obtaining a more inclusive picture of firm-level entrepreneurship combining EO and CE is needed. This synthesized measurement covers both exploration and exploitation components of the process, and both attitudinal and behavioral elements of the concept.

\subsection{Entrepreneurial Orientation}

Perhaps the most popular, albeit most controversial construct of firm-level entrepreneurship is EO. It is one of the long-standing conceptualizations in the field. EO has its roots in the strategic management literature and refers to the management styles of companies having entrepreneurial orientation (Becherer \& Maurer, 1997; Lumpkin \& Dess, 1996a, 2001). The first researcher who recognized and presented the benefits of having an entrepreneurial strategy-making style at firms was Mintzberg (1973). He identified three different types of corporate strategies: entrepreneurial, planning, and adaptive. Four years later, Khandwalla (1977) introduced the different dimensions of the strategy-making process including adaptiveness, analysis, integration, risk-taking, and product-market innovation. He described entrepreneurial companies as organizations which are inclined to take high-risk, high-return projects; are aggressive in perusing 
entrepreneurial opportunities; initiate innovative actions that are responded to by competitors later; and are frequently the first companies that introduce new products and services. This characterization of entrepreneurial companies formed the foundation of Miller's construct, which distinguished entrepreneurial companies in terms of innovativeness, proactiveness, and risk-taking (Covin \& Slevin, 1991; Miller, 1983). By introducing this construct - named "entrepreneurial posture" by Miller (1983) and subsequent researchers such as Covin and Slevin $(1989,1991)$, and called "entrepreneurial orientation" by other scientists like Lumpkin and Dess (1996a) - the field received substantial academic attention.

As the very first studies discussed, EO reflects the firm's strategic orientation (Covin \& Slevin, 1989) or the tendency of a given firm to be innovative, proactive, and a risk-taker in relation to business opportunities (Miller, 1983). It delimitates firm-level entrepreneurship to a tendency, a style of decision-making (Covin \& Slevin, 1991), or an entrepreneurial strategic posture (Rauch, Wiklund, Lumpkin, \& Frese, 2009). It gradually became the most popular construct of firm-level entrepreneurship, and a large number of researchers employed it to study the phenomenon (e.g. Covin \& Lumpkin, 2011; Rauch et al., 2009; Runyan, Ge, Dong, \& Swinney, 2012; Wales et al., 2011; Wales, Patel, Parida, \& Kreiser, 2013). EO is still an essential part of strategic management studies (Slevin \& Terjesen, 2011), and has become a dominant topic in the entrepreneurship literature (Wiklund, 1999). It has received much more empirical and conceptual attention than any other construct (Covin et al., 2006) of entrepreneurship, and is among the few concepts that have obtained a cumulative body of knowledge (Rauch et al., 2009). As noted by Covin and Lumpkin (2011), the number of EO publications totals more than all the other concepts of firm-level entrepreneurship combined, and Miller's (1983) and Covin and Slevin's $(1989,1991)$ work has been citied more than 1000 times each (Slevin \& Terjesen, 2011).

Popularity is often accompanied by contradictions, and this is also true in the case of EO. While the number of empirical and conceptual studies grew, some challenges were raised about the conceptualization of EO (Covin \& Lumpkin, 2011; Lumpkin \& Dess, 1996a; Rauch et al., 2009; Slevin \& Terjesen, 2011; Wales et al., 2011). This confusion 
gave rise to different names and labels for the notion of an orientation toward firm-level entrepreneurship (e.g. entrepreneurial posture, orientation, style, propensity, proclivity and even corporate entrepreneurship in some cases (Covin \& Wales, 2012)), led to the disproportionality of empirical findings, and impaired the shared understanding of the concept (Rigtering, Kraus, Eggers, \& Jensen, 2013). In short, these challenges prevented researchers from reaching a uniform conceptualization of EO (Covin \& Lumpkin, 2011). In the absence of a universal explanation, defining a clear and inclusive conceptualization of the concept is necessary. A clear and inclusive conceptualization should carefully describe its points of view regarding the construct nature (attitudinal vs. behavioral), measurement model (reflective or composite) and the number of indicators.

The first dilemma, originating from the very first studies, is the nature of the construct, i.e. whether it is an attitudinal construct which measures tendencies and orientations, a behavioral construct which shows actions and behaviors, or both (Covin \& Lumpkin, 2011; Miller, 2011). Covin and Slevin (1991) described EO as the top management tendency to undertake risky projects, the number of product innovations and related tendency to be an industrial leader, and the propensity to aggressively and proactively compete with rivals. In this conceptualization, the number of product innovations, which represents the dimension of innovativeness, has a clearly different nature than others. Actually, the first definition of EO included both attitudinal and behavioral components. This mixed type of conceptualization was echoed by Covin et al. (2006, p. 57), who defined EO as;

... a strategic construct whose conceptual domain includes certain firm-level outcomes and management-related preferences, beliefs, and behaviors as expressed among a firm's top-level managers.

The mixed type of conceptualization, which combines both the items that quantify past behaviors and the items that measure present attitudes in a single construct, has been severely criticized (Brown et al., 2001; Wiklund, 1999). A theoretically valuable construct should be attitudinal or behavioral, but it cannot be both (Covin \& Lumpkin, 2011) because attitudes and behaviors reinforce each other and do not share similar antecedents and consequences (Anderson, Kreiser, Kuratko, Hornsby, \& Eshima, 2014). This is an 
especially big challenge when EO is defined as a reflective construct. In addition, the mixed conceptualization is not in agreement with the common theoretical definition of EO. Lumpkin and Dess (1996a, p. 136) define EO as "the processes, practices, and decision-making activities that lead to new entry". They obviously describe EO as the processes, practices, and decision-making activities and separate it from new entry. Regardless of this exact demarcation, EO has been operationalized in a way that includes some items representing processes, practices, and decision-making activities (EO1, EO4, EO5, EO6, EO7, EO8, EO9), and others that imply new entry (EO2, EO3) (Covin \& Miller, 2013). Finally, the mixed conceptualization may harm the nominal meaning of EO. Researchers are advised to respect the nominal meaning of constructs in their operationalization (Covin \& Wales, 2012). Arranging two different types of indicators in a single construct usually violates the nominal meaning. All in all, research should sharply differentiate the attitudinal and behavioral aspects (Miller, 2011) and clearly conceptualize EO as a behavioral or attitudinal construct, not both.

Another question that needs to be answered is what is the nature of EO. Is it an altitudinal or a behavioral construct? Actually, EO as a behavioral construct also defies the nominal meaning. The letter "O" in the abbreviation obviously refers to "orientation". Moreover, the behavioral conceptualization does not conform to the common theoretical definition. From the theoretical point of view, EO "most assuredly represents an orientation" (Covin \& Lumpkin, 2011, p. 857). Orientation is defined as;

"The firm's basic culture, that is, the fundamental and dominant pattern of beliefs and values that management emphasizes on a continuous basis to guide the organization" (Knight, 2001, p. 159).

It shows the tendency of an organization to respond to situations, or classes of situations, and seems to fit well with EO as an attitudinal construct (Covin \& Lumpkin, 2011).

Despite a few papers that define EO as a behavioral construct (e.g. Morris, Webb, \& Franklin, 2011), most studies have conceptualized it as a kind of disposition, mindset, willingness, or tendency (Lumpkin \& Erdogan, 1999), which imply to the attitudinal 
nature of the construct. For instance, Naman and Slevin (1993, p. 143) described EO as "the willingness to take business-related risk, the willingness to be proactive when competing with other firms, and the willingness to innovate" and Lumpkin and Dess (2001, p. 432) briefly defined it as "the mindset of firms engaged in pursuing new ventures". The literature is full of different names and expressions, which speak to the attitudinal conceptualization of EO such as strategic orientation (Hughes \& Morgan, 2007; Wiklund \& Shepherd, 2003) or disposition (Knight, 1997; Zahra et al., 2013b). In their meta-study, Rauch et al. (2009) distinguished EO from entrepreneurial decisions and actions and defined it as the strategy-making processes that serve as a basis for entrepreneurial decisions and actions. In a discussion of epistemology of entrepreneurial orientation, George and Marino (2011) stated that EO, as suggested by numerous authors, represents processes, methods, and decision making or an overall strategic posture, which is intended to measure an invisible construct of firm's proclivity toward entrepreneurial behavior.

Another important issue is EO dimensionality, which caused substantial arguments in the literature (Lumpkin \& Dess, 2001; Wiklund \& Shepherd, 2005). There have been severe and detailed debates on EO dimensionality (George, 2011); thus, determining proper dimensionality becomes an indispensable prerequisite in every EO study (Covin et al., 2006). A latent construct (a construct that is not directly observable) can be conceptualized in two different models: reflective or formative (Diamantopoulos, Riefler, $\&$ Roth, 2008). These measurement models are discussed in detail by researchers and statisticians (please look at Jarvis, MacKenzie, \& Podsakoff, 2003; MacKenzie, Podsakoff, \& Jarvis, 2005) and there are useful guidelines about how they should be applied.

The dominant approach in management and entrepreneurship is reflective modeling (MacKenzie et al., 2011). In this approach, each dimension reflects the whole construct with a certain amount of error, while under a formative specification, an aggregation of all the dimensions forms the whole construct (Anderson et al., 2014). In other words, a reflective measurement focuses on the shared variance (Covin \& Wales, 2012), while a formative measurement counts on the collective variance of indicators to 
measure a latent construct. The presumed direction of causality is from the construct to indicators for reflective models, and vice versa for formative models (Covin \& Wales, 2012). Consequently, under a reflective approach, all indicators are in the same direction, are highly correlated, and have similar antecedents and consequences. In formative models, however, indicators have their own directions, which can be in contrary to each other, and the indicators are not necessarily expected to have similar antecedents and consequences (MacKenzie et al., 2005). Accordingly, the number of dimensions is a matter of great importance for formative measurements, but it is not a big challenge when reflective models are concerned.

EO can be modeled as either a reflective or formative measurement (Covin \& Wales, 2012). As George (2011) claimed, having this duality in the EO literature originated from Miller's (1983) original work. Miller defined an entrepreneurial firm as "one that engages in product-market innovation, undertakes somewhat risky ventures, and is first to come up with proactive innovations" (P. 771). The word "and" in this definition implies a reflective measurement (George, 2011). But later he stated, "we can tentatively view entrepreneurship as a composite weighting of these three variables" (p. 771). This statement proposes an entirely different relationship between EO and its dimensions, and signifies a formative measurement (George, 2011). Other researchers such as Lumpkin and Dess (1996) further fueled this contradiction and turned it into one of the most controversial arguments in the literature (Covin \& Miller, 2013). This confusion has led to principal inconsistency between theories and empirical discussions. There are a considerable number of studies that are drawn upon theories, which seems consonant with the formative approach, but treat EO as a reflective measurement in their empirical analyses and discussions (George, 2011). Indeed, each measurement model has its own proper analysis techniques, and the inconsistency between the measurement model and analysis techniques could lead to inconclusive results. Therefore, a reasonable study is expected to clearly determine its measurement model and utilize relevant techniques to avoid inconsistency.

Each measurement model has its own advantages and disadvantages, and researchers should apply the model that best fits with the purpose of their study. For 
example, reflective models enjoy parsimony, but may disguise the unique contribution of each dimension in the whole construct (Kreiser, Marino, \& Weaver, 2002). Rauch et al. (2009) confirmed that most studies modeled EO as a reflective measurement, because its dimensions are highly correlated. In a more recent study, George and Marino (2011, p. 1000) endorsed the reflective model of EO, arguing the direction of causality;

Because EO's meaning emanates from the higher-order construct to its dimensions, changes in EO would only be evidenced by changes in all three dimensions.

They explicitly recommended that “... a reflective model of EO is more consistent with the theoretical and conceptual definition of the construct" (P. 1002). Their recommendation was echoed by Covin and Wales (2012), who declared that the formative measurement model may harm the conceptualization of EO as a single and distinct construct because it allows a firm to have moderately high EO, even in absence of one dimension. This is not in agreement with the early conceptualization of the construct, and it is better to reserve the label of EO for a conceptualization that is consistent with the reflective approach (George, 2011). In other words, formative modeling of EO represents another construct, which is not an alternative conceptualization of the same construct (Covin \& Lumpkin, 2011; Covin \& Miller, 2013; Covin \& Wales, 2012). In contrast, some researchers advocated the formative approach; they discussed the independency (Kreiser et al., 2002; Lumpkin \& Dess, 1996a, 2001; Moreno \& Casillas, 2008) and the unique contribution of each dimension in the whole construct (Hansen, Deitz, Tokman, Marino, $\&$ Weaver, 2011). They argued that the formative measurement model can bestow researchers with important information on the distinct consequences of each dimension, and may result in more detailed conclusions. In addition, applying a formative measurement model can reduce the probability of individual dimensions cancelling each other out (Dai, Maksimov, Gilbert, \& Fernhaber, 2014).

Despite the fact that EO dimensions may neutralize each other in a reflective model, the majority of studies modeled it as a reflective construct. Kreiser et al. (2002) found that 18 papers out of 19 defined EO as a reflective measurement. In the same vein, 37 of 51 papers reviewed by Rauch et al. (2009) also applied the reflective model of EO. 
Recent studies even showed more promising results in favor of the reflective measurement model of EO: 39 out of 46 (Runyan et al., 2012) and 123 out of 158 (Wales et al., 2011). The fact that the majority of empirical studies conceptualize EO in a reflective measurement model shows that there is a solid unification on Miller's conceptualization (Wales et al., 2011). Furthermore, there are several studies that conceptualize EO as a formative construct but apply improper analysis techniques, which causes the inconsistency between theories and empirical discussions. By taking all into account and with attention to the benefits of both conceptualizations, it is advised to select a measurement model which is apt with the research purpose and questions (Covin et al., 2006; Covin \& Wales, 2012).

If research questions have focused on the antecedents and consequences of individual dimensions, and if the purpose of study is to investigate the independent influences of each dimension, the formative model fits better (Rauch et al., 2009). In contrary, when the antecedents and consequences of the whole construct are the main concern, and the purpose of study is to examine the effect of the whole construct of EO, the reflective model is more appropriate. The purpose of this research is to study EO as an individual dimension of a higher order construct of firm-level entrepreneurship, and the effect of its individual dimension is not in focus; therefore, the reflective model is a better fit.

A very original conceptualization of EO, the reflective model proposed by Miller (1983) listed the three indicators of innovativeness, proactiveness, and risk-taking. Later, Lumpkin and Dess (1996a) questioned Miller's conceptualization, defined EO as a formative construct, and added two other dimensions: aggressiveness and autonomy. Throughout the literature, there are studies that have employed a modified version of EO with more or less than three dimensions. A meta-analysis study revealed that using a slightly modified version of EO with more or less dimensions does not affect the overall validity of the construct (Rauch et al., 2009). Actually, the number of dimensions is not a big concern of reflective measurement models (George, 2011); thereby, this study simply adheres to Miller's three-dimensional conceptualization because it is more popular (Rauch 
et al., 2009). According to Wales et al. (2011), about 80 percent of all reflective measurement papers have applied this conceptualization.

In short, EO in this dissertation is conceptualized as an attitudinal reflective measurement that is defined by the three dimensions of innovativeness, proactiveness, and risk-taking. This conceptualization is in line with Stam and Elfring (2008, p. 98), who described EO as "the simultaneous exhibition of innovativeness, proactiveness, and risktaking”.

Perhaps, the most controversial dimension of EO is innovativeness, which is frequently confused with innovation. When reviewing the literature, two different conceptualizations of innovativeness come to light: innovativeness as the degree of the newness of a product or a service (Olson, Walker, \& Ruekert, 1995; Veflen Olsen \& Sallis, 2006), and innovativeness as the capacity of a given organization to engage in innovation (Damanpour, 1991; Hult, Hurley, \& Knight, 2004). The first conceptualization, which is also less common in the innovation literature, is not what EO defines as innovativeness. Innovativeness in EO studies is a better fit with the second conceptualization (Vora, Vora, \& Polley, 2012), which explains it as the tendency and capacity of a company to engage in innovation that should be separated from established practices and technologies (Hansen et al., 2011; Parkman, Holloway, \& Sebastiao, 2012).

Unfortunately, the lack of consistency in its conceptualization has directed studies to treat "innovativeness" and "innovation" as interchangeable concepts (Garcia \& Calantone, 2002). As Hult et al. (2004) explained, innovation is a new technology, a new product (service), a new production process, or a new structure or practice in an organization, while innovativeness shows the tendency to support creativity, experiments (Huang \& Wang, 2011) or increase the R\&D expenditure to develop new products, processes and technological leadership positions (Dess \& Lumpkin, 2005; Hughes \& Morgan, 2007; Lumpkin \& Dess, 1996a; Rigtering et al., 2013). Other studies went further and defined innovativeness as a firm's cultural orientation towards innovation (Hult, Snow, \& Kandemir, 2003), as opposed to the capacity to innovate (the ability of a firm to successfully adopt and implement new ideas, products and processes) (Hurley \& Hult, 1998) and innovation (as the new outputs of the innovation process). Interchangeable use 
of innovativeness and innovation could lead to ambiguous conclusions and reduces the practical application of empirical research (Garcia \& Calantone, 2002). In some industries, innovativeness is a common tendency and the products, services or processes deriving from that tendency determine why they act differently (Hornsby, Bloodgood, Hayton, \& Kuratko, 2013). In a few words, innovativeness is an attitudinal concept which shows the tendency of a firm to support creativity, and experimentation and may lead to innovation, a behavioral concept, which is realized as new products, technologies or practices (Knight, 2000; Rauch et al., 2009).

Proactiveness refers to the propensity of a firm to see new opportunities, which may or may not be related to the current line of production, introduce new products and processes ahead of competitors, and eliminate those products that are in the declining stages of their life cycles (Venkatraman, 1989b). Proactive companies are forward-looking on trends, enjoy being pioneers in their markets, and affect their environments by introducing new technologies and practices ahead of the competition (Knight, 2000; Lyon et al., 2000). They regularly search for market opportunities and try to find proper responses to their environmental changes (Venkatraman, 1989b). In clear words, proactiveness is an organizational posture or disposition which is characterized by an opportunity-seeking, forward-looking perspective that forecasts and acts upon forthcoming wants and needs (Rauch et al., 2009; Wiklund \& Shepherd, 2005) and actively challenges rivals in hunting propitious opportunities (Hansen et al., 2011). This orientation helps companies to monitor trends, identify future needs, understand changes in demand and find favorable new opportunities (Dess \& Lumpkin, 2005).

The last indicator of the triad of EO that reflects the propensity to assign resources to projects with high possibility of both return and failure (Hansen et al., 2011; Knight, 2000 ) is known as risk-taking. The outcome of a risky project is not clear, and the cost of failure is usually high (Miller \& Friesen, 1982; Wiklund \& Shepherd, 2005). Risk-takers are characterized by daring actions such as heavy loans for investing in the unknown or devoting a large amount of resources to ventures in uncertain environments (Rauch et al., 2009). This orientation is reflected in managers' decisions about allocating resources or selecting and investing in new products and services (Perez-Luno, Wiklund, \& Cabrera, 
2011). It has been recognized as one of the most substantial dimensions of a firm's innovation culture (Hult et al., 2004).

\subsection{Corporate Entrepreneurship}

The second popular measurement of firm-level entrepreneurship that was developed by Guth and Ginsberg (1990) and refined by Zahra (Zahra, 1991, 1993b) is called CE. It is a behavioral construct that measures the engagement of a company in entrepreneurship actions, captures its actual entrepreneurial behavior, and in this way differs from previously defined measurements of EO that depict the predisposition of companies in regard to their firm-level entrepreneurial activities (Simsek et al., 2007). This construct is frequently defined by the three dimensions of innovation, venturing, and strategic renewal (Antoncic \& Hisrich, 2004). It has evolved during the last four decades, and its definition has changed over time (Kuratko \& Audretsch, 2013). This concept seems more straightforward than EO, but still suffers from some ambiguities, which need to be clarified. Similar to EO, researchers have used various expressions to name corporate entrepreneurship such as intrapreneurship (Pinchot, 1985), corporate entrepreneurship (Burgelman, 1983, 1984), and corporate venturing (Vesper, 1990). Although intrapreneurship is different from what is called corporate entrepreneurship in this research, and deals with characteristics of individuals who perform entrepreneurial initiatives at the organizational level (Pinchot, 1985), other labels deal with entrepreneurial activities in an entire company. As Jennings and Lumpkin (1989) claimed, there is no unified definition of corporate entrepreneurship. Therefore, it is necessary to review the construction, its dimensions, and its conceptualization to achieve a comprehensive and appropriate definition.

Before Guth and Ginsberg's (1990) seminal paper, CE was usually confused with other organizational concepts such as new product development, which were associated with innovation, (Corbett, Covin, O'Connor, \& Tucci, 2013), and its conceptual domain was not clear. Consequently, a majority of early studies attempted to define a distinct scope that separates CE from other innovation-related constructs and start-up entrepreneurship concepts (Zahra et al., 2013b). Guth and Ginsberg (1990) distinguished 
CE activities by limiting them to two separate categories: corporate venturing, which is described as "the birth of new businesses within existing organizations" (p. 5), and strategic renewal, which is defined as "the transformation of organizations through renewal of the key ideas on which they are built” (p. 5). Subsequent studies expanded this conceptualization to the three dimensions of innovation, venturing, and strategic renewal (Sharma \& Chrisman, 1999; Zahra, 1993a, 1995). Whereas more recent studies incorporate innovation and strategic renewal in one dimension of strategic entrepreneurship and propose a two-indicator construct of CE (e.g. Morris, Kuratko, \& Covin, 2011; Phan, Wright, Ucbasaran, \& Tan, 2009), this study has applied the triad conceptualization because it has earned more popularity. In addition, the strategic entrepreneurship dimension of CE covers a wide variety of specific phenomena such as innovation and strategic renewal (Corbett et al., 2013), and is difficult to operationalize.

Another important discussion is the formal and informal activities of CE. Formal activities are developed in line with the firm's existing mission and goals (Zahra, 1996a), while informal activities are introduced by people or groups who follow their own specific interests (Zahra, 1991). Accordingly, corporate entrepreneurship is defined as the formal and informal activities used to raise innovation, venturing, and strategic renewal. This definition is in accordance with Zahra (1991, 1996a; 2001), who describes CE as the formal and informal entrepreneurial activities at the organizational level aimed at revitalizing a firm's business by increasing its innovation or changing its competitive profile. In clearer words, $\mathrm{CE}$ is the process of creating new businesses or transforming companies by changing their business domain or key strategies through innovation (Guth \& Ginsberg, 1990; Teng, 2007), and it is linked to the firm's effort to establish sustainable competitive advantage (Ireland, Kuratko, \& Morris, 2006).

Sharma and Chrisman (1999) stated that different dimensions of CE can have their own antecedents and consequences, and this claim is in agreement with the formative measurement model. Nevertheless, there is a common agreement among researchers about $\mathrm{CE}$ as a higher order construct that has been reflected by innovation, venturing, and strategic renewal (Heavey \& Simsek, 2013; Simsek \& Heavey, 2011). Zahra (1995, p. 227) defines CE as "the sum of a company's innovation, renewal and venturing efforts", 
and Morris, Kuratko, et al. (2011, p. 12) confirmed the common core of three dimensions by stating that they "are all important and legitimate parts of the concept of corporate entrepreneurship". Consequently, the reflective measurement model of CE fits better with the purpose of this research, since it is conceptualized as a distinct dimension of the higher order construct of firm-level entrepreneurship.

The organization for Economic Cooperation and Development (OECD) (2005, p. 46) describes innovation as;

The implementation of a new or significantly improved product (good or service), or process, a new marketing method, or a new organizational method in business practices, workplace organization or external relations.

As described previously, innovation departs from innovativeness, a concept that describe the capacity and orientation towards innovation (Garcia \& Calantone, 2002). It can be considered as the tangible combinations of assets (Nahapiet \& Ghoshal, 1998), discoveries that lead to production and increase the economic value of a company (Garcia \& Calantone, 2002), and a firm's commitment to introduce new products, services, and production processes (Zahra, 1996a). Innovation is a substantial part of entrepreneurship (Kearney, Hisrich, \& Antoncic, 2013) that is related to the successful exploitation of entrepreneurial opportunities (Alegre \& Chiva, 2013), and which acts as a foundation for other dimensions of CE such as strategic renewal (Kelley, Peters, \& O'Connor, 2009) and venturing. In this study, innovation is considered as the activities of introducing new products, technologies, and processes. Dissimilar to innovativeness, which mainly deals with capacity and creating a supportive environment, innovation can be recognized by two distinct characteristics: newness and implication.

Corporate venturing entails all the activities of creating new businesses within or by an established company. This kind of activities can occur throughout the company (Zahra, 1993b) in the form of internal, external, or cooperative ventures (Kuratko \& Audretsch, 2013; Zahra \& Hayton, 2008). Internal venturing takes place within, while external venturing occurs outside the boundaries of a company (Zahra, 1991). Internal ventures are owned by their parent firms, reside within (internal) and sometimes outside 
of (external) the current organizational structure, and on some occasions, may operate as semi-independent entities (Kuratko \& Audretsch, 2013). External ventures are created by outside people (companies) and then acquired by the parent firm. Cooperative ventures started through a cooperation between a parent firm and one or more external partner(s) (Kuratko \& Audretsch, 2013). At all events, the overall venturing of a company is equal to the sum of all types of venturing to include internal, external and cooperative ventures (Zahra \& Hayton, 2008).

Renewing or redefining a firm's relationships with its markets and competitors (Floyd \& Lane, 2000), transforming substantial values that lead the company's strategic moves (Antoncic, 2007; Zahra et al., 2013b), and acquiring new knowledge to modify core competencies or to change the strategic position (Memili, Lumpkin, \& Dess, 2011) is called strategic renewal. It requires flexibility and adaptability (Kearney et al., 2013), and leads to adopting new organizational structures that provoke innovation and venturing (Zahra, 1993b). In reality, strategic renewal takes different forms, such as redefinition of the business concept, introducing new system-wide changes, or modifying the organizational structure to support innovation (Zahra, 1993b). It can be measured by looking at the changes in the current position of a company compared to its previous standpoint or industry standards (Hornsby et al., 2013).

\subsection{A Profile Measurement Model of EO-CE}

In spite of all the attempts to conceptualize and measure firm-level entrepreneurship, it is still regarded as an ill-defined construct (Stopford \& Badenfuller, 1994). Our knowledge of the concept remains limited and fragmented (Miles \& Covin, 2002), and the fierce argument about its conceptualization and operationalization continues (Lyon et al., 2000). As previously argued, researchers have developed different conceptualizations of the phenomenon such as business venturing and strategic renewal (Guth \& Ginsberg, 1990), new market entries (Vesper, 1990), the characteristics of entrepreneurial firms and their employees (Jennings \& Lumpkin, 1989), entrepreneurial orientation (Covin \& Slevin, 1991; Miller, 1983), and corporate entrepreneurship (Zahra, 1991, 1993b, 1995). Among 
all, EO and CE found more popularity and are commonly used to measure firm-level entrepreneurship (Antoncic \& Hisrich, 2001, 2004).

In practice, researchers are very inclined to measure firm-level entrepreneurship using EO to the extent that causes the problem of over-consistency. Zahra et al. (1999) warned about over-consistency on the construct of EO and disclosed their concerns about accepting a common measurement without establishing its dimensionality and other psychometric aspects. Despite the valuable contributions of EO, its popularity may limit the development of new alternative measurements (Covin \& Lumpkin, 2011), which is extremely needed. About 16 years ago, Zahra et al. (1999, p. 51) suggested “... to conceptually integrate Miller's (1983) and Guth and Ginsberg's (1990) classifications of firm-level entrepreneurship". This notion has recently been echoed and recommended as a way to help extend the conceptual domain of firm-level entrepreneurship (Anderson et al., 2014; Miller, 2011). Despite all the calls and recommendations, little progress has been made in designing and developing new conceptualizations (Covin \& Wales, 2012). As discussed before, firm-level entrepreneurship has two foundational components, attitudinal and behavioral (Kuratko, Ireland, \& Hornsby, 2004), and measuring one dimension without considering the other draws an incomplete picture.

EO shows the orientation, not the firm's actual engagement in entrepreneurship (Zahra, 1991). EO has mainly focused on intensity (Covin \& Slevin, 1993) and failed to distinguish itself from formality, type (locus), and duration; therefore, it may cause the misspecification of linking firm-level entrepreneurship to performance (Zahra, 1993a) or internationalization. From a methodology perspective, attitudes account for a small part of variance in individual and organizational behavior (Davis-Blake \& Pfeffer, 1989), and the actual behavior of a company is determined by both attitudes and situations (House, Shane, \& Herold, 1996). On the whole, EO cannot account for the whole entrepreneurial situation of an organization (Zahra, 1993a) and provides an incomplete understanding (Hagen, Zucchella, Cerchiello, \& De Giovanni, 2012) of firm-level entrepreneurship. Along the same line of thought, $\mathrm{CE}$ is also not a true representative and delivers an incomplete image because it only captures the behavioral component while ignoring the attitudinal dimension. 
EO and CE are used interchangeably in some studies because of their unclear conceptualizations (Sharma \& Chrisman, 1999), the lack of theoretical clarity in their specification (Memili et al., 2011), or the extensive implementation of Covin and Slevin's construct of EO (Zahra et al., 2013b). This study, however, has precisely conceptualized these constructs as two distinct but related dimensions of firm-level entrepreneurship (Antoncic \& Hisrich, 2003), which aim at different characteristics. Actually, EO displays an orientation while CE shows entrepreneurial behavior and activities (Knight, 1997). Consequently, they cover separate dimensions of firm-level entrepreneurship (Zahra, 1991) and it is necessary to measure both to obtain a complete picture. A synthesized construct of both $\mathrm{EO}$ and $\mathrm{CE}$ seems a better fit with the more extended conceptualization of firm-level entrepreneurship proposed by this study. Sciascia and Bettinelli (2013) presented a similar conceptualization, referring to firm-level entrepreneurship as a broad concept that should cover both content and propensity. This type of conceptualization, which incorporates both attitudinal and behavioral aspects, enables researchers to develop more validated measurements of firm-level entrepreneurship (Zahra et al., 1999) and is highly recommended (Dess et al., 2003). This notion is also praised by Rauch et al. (2009), who reviewed EO studies and concluded that there is room for Covin and Slevin's construct as well as new alternative measurements.

Integrating EO and CE to measure firm-level entrepreneurship can improve the current literature in many ways. It has better potential to answer existing challenges, such as how to manage EO (Wiklund \& Shepherd, 2011) in a way that leads to successful new entry. New entry is considered a typical entrepreneurial behavior and is defined similarly to corporate entrepreneurship. Therefore, measuring both orientation and new entry as different dimensions of the same construct allows researchers to come up with new ideas about how they really covariate and what we should do to manage their covariation. In addition, it could clarify why empirical findings of EO and performance are inconsistent (Lyon et al., 2000). EO requires a large commitment of resources to affect the performance (Hitt, Ireland, Camp, \& Sexton, 2001; Su, Xie, \& Wang, 2015; Tang et al., 2008; Wiklund \& Shepherd, 2005) that potentially imposed a significant cost (Dai et al., 2014; Wales et al., 2013). Innovation needs a substantial upfront investment (Kreiser, Marino, Kuratko, 
\& Weaver, 2012; Rosenbusch, Brinckmann, \& Bausch, 2011), proactiveness results in an immense budget for searching and learning (Bell, 1995; Dai et al., 2014; Kreiser et al., 2012), and risk-taking causes a huge loss when a project fails (Dai et al., 2014). In reality, EO can lead to entrepreneurial behavior when the required resources are available. Obviously, entrepreneurial orientation alone does not ensure that a company is entrepreneurial (Stam \& Elfring, 2008), and draws a naïve understanding of its performance (Morgan, Vorhies, \& Mason, 2009). One of the researchers who delved deeply into the relationship of orientation and performance was Knight (2001). He concluded that a three-step process of "orientation-strategies-performance" better explains what it is happening in practice. Generally, strategy is defined as;

Pattern of present and planned resource deployments and environmental interactions that indicates how the organization will achieve its objectives (Hofer \& Schendel, 1978, p. 25).

An entrepreneurial strategy could be seen as;

A vision-directed, organization-wide reliance on entrepreneurial behavior that purposefully and continuously rejuvenates the organization and shapes the scope of its operations through the recognition and exploitation of entrepreneurial opportunity (Ireland, Covin, \& Kuratko, 2009, p. 194).

Because CE measures actual entrepreneurial behavior and includes continuous rejuvenation of the organization, it could be interpreted as a typical form of entrepreneurial strategy. Accordingly, Knight's process of "orientation-strategies-performance" is equivalent to "EO-CE-performance". Several studies followed this process to investigate the relationship of EO and internationalization and came up with interesting findings. For instance, Knight (2001) applied a case study approach and showed that the three-step causal chain better justified the association between EO and internationalization. He concluded that "it is possible to frame the case-study findings in terms of a causal chain reflecting orientation $\rightarrow$ strategies $\rightarrow$ performance" (P. 159). In another study, Jantunen et al. (2005) could not find a direct connection between EO and the degree of internationalization, and explicitly expressed that; 
It may be that the firms in our sample had already adopted a certain orientation, i.e. a culture and a dominant pattern of beliefs and values, and that it is the actual company strategies (in the context of its orientation) that shape the degree of internationalization more. This reflects the causal chain "orientation $\rightarrow$ strategies $\rightarrow$ performance" proposed by Knight (2001), but still warrants further research (P. 237).

All in all, an integrated conceptualization of firm-level entrepreneurship enables researchers to study how they should manage EO in a way that leads to new entries and draws a more reliable picture of the firm-level entrepreneurship and performance relationship.

It is not wrong to say that $\mathrm{EO}$ and $\mathrm{CE}$ reinforce and complement each other. $\mathrm{EO}$ is considered a managerial attitude that may serve as the basis for entrepreneurial decisions and actions (Alegre \& Chiva, 2013; Lumpkin \& Dess, 1996a), but it does not mean that EO is a necessary condition for CE. In simple terms, EO may sometimes act as the antecedent of $\mathrm{CE}$, but this is not always true. $\mathrm{CE}$ and $\mathrm{EO}$ can exist independent of each other. Actually, an external force can impose some forms of CE in the absence of EO. Also, there are some companies, especially small ones, that do not have access to required resources to convert their orientations to actual outputs. It is not fair to call a company "entrepreneurial" because it shows an orientation or some form of entrepreneurial behavior. A true entrepreneurial company is an organization with entrepreneurial orientation which leads to new entries. It means that a company should simultaneously depict both orientation and behavior to be called entrepreneurial. In fact, a considerable number of existing studies have only studied the effect of entrepreneurial orientation or corporate entrepreneurship on performance, not the effect of firm-level entrepreneurship on performance (Antoncic et al., 2004).

Despite all the aforementioned benefits of developing an integrated measurement, attempts at crossing EO and CE have remained few (Bouchard \& Basso, 2011). Antoncic and Hisrich (2001) combined innovativeness and proactiveness of EO and venturing and self-renewal of CE into a broader concept of firm-level entrepreneurship. They counted three reasons to justify their notion; 
(1) Their validity cannot be fully assessed when they are used separately; (2) if used together, they may be partly redundant; and (3) both have limited generalizability (P. 500).

In the same vein, Goosen, De Coning, and Smit (2003) developed an integrated three-dimensional construct of firm-level entrepreneurship. They listed innovativeness, proactiveness, and management as the three dimensions of their construct. Their management dimension was comprised of several sub-dimensions such as creativity, innovation, communication, and so on. In a more recent attempt, Anderson et al. (2014) conceptualized EO as a two-dimensional concept of entrepreneurial behavior and managerial attitude toward risk. They actually classified innovativeness and proactiveness as the behavioral and risk-taking as the attitudinal aspect of firm-level entrepreneurship. These mixed conceptualizations proposed a broader measurement of firm-level entrepreneurship but they also have some weaknesses: (1) they combine attitudinal and behavioral components into a single latent construct, which harms the nominal meaning and the applicability of measurements; (2) they break well-established constructs of EO and $\mathrm{CE}$ into less popular constructs; and (3) they treat innovativeness and innovation as interchangeable concepts. To overcome these challenges in the current study, innovativeness and innovation are clearly conceptualized as two distinct concepts, and a profile measurement model is employed that does not break well-established constructs apart or harm the nominal meaning and applicability of the measurements.

A profile measurement model assigns a specific group to an entity based on the combinations of its dimensional characteristics (Law, Wong, \& Mobley, 1998). To design an appropriate profile model of firm-level entrepreneurship, it is extremely important to determine the nature of the model's dimensions (MacKenzie et al., 2011). As previously discussed, both EO and CE were defined as reflective constructs which, respectively, mirror entrepreneurial attitude and entrepreneurial behavior. Integrating these two dimensions in a profile model results in four groups of companies: High EO - High CE, High EO -Low CE, Low EO - High CE, and Low EO - Low CE. This classification fits well with the conceptualization of firm-level entrepreneurship in this research and 
overcomes the aforementioned challenges of other integrated measurements. It also can be viewed as a reply to Covin and Lumpkin (2011, p. 867), who call to;

Employ cluster analysis to identify groups of firms with similar profiles.... Theory might then be developed and tested to explain why, for example, the entrepreneurial profiles differ across the clusters.

Figure 2-2 shows the profile model of EO-CE.

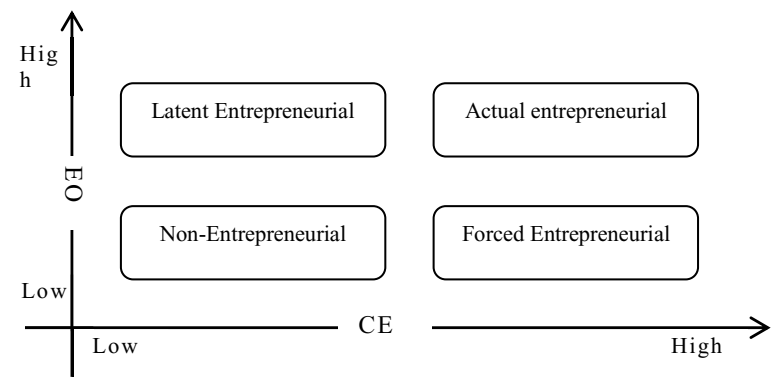

Figure 2-2: The profile model of firm-level entrepreneurship

To check if the model is rich and validate from a conceptual standpoint, MacKenzie et al.'s (2011) guidelines are applied. They counted three major challenges that may harm the validity or richness of a measurement model;

... (1) fail to adequately discuss how to develop appropriate conceptual definitions of the focal construct, (2) often fail to properly specify the measurement model that relates the latent construct to its indicators, and (3) underutilize techniques that provide evidence that the set of items used to represent the focal construct actually measures what it purports to measure" (P. 293).

This study first discussed the conceptualization of firm-level entrepreneurship (as the focal construct) in detail and developed an appropriate conceptual definition; second, all existing conceptualizations of firm-level entrepreneurship were explained, their conceptual domains were determined, and EO and CE were selected as more validated concepts that can jointly deliver a more comprehensive picture; and third, EO and CE were defined as reflective measurements and firm-level entrepreneurship was modeled as a 
profile construct. Therefore, all guidelines were respected and the proposed profile model could be considered a rich and valid measurement.

The profile model, in its general approach, is not new in the field. Zahra et al. (1999) applied this approach to study the link between a firm's external environment, corporate entrepreneurship and financial performance. They combined the three dimensions of entrepreneurial act (innovation and venturing), the locus of entrepreneurial act (internal vs. external), and the source of entrepreneurial act (formal vs. informal) in an eight-fold profile model. Atuahene-Gima and Ko (2001) conjoined EO and market orientation and categorized companies into the four groups of market/entrepreneurship orientation, entrepreneurship orientation, market orientation, and conservative. In another study, Jambulingam, Kathuria, and Doucette (2005) classified companies into six different clusters (competitive aggressors, ambitious, true entrepreneurs, low-risk entrepreneurs, proactive innovators, and anything but entrepreneurs) based on risk-taking, innovation, motivation, proactiveness, competitive aggressiveness, and autonomy. Sundqvist, Kylaheiko, Kuivalainen, and Cadogan (2012) distinguished Schumpeterian and Kirznerian EO, defining the first as the aggregation of proactiveness and competitive aggressiveness, and the latter as the sum of innovativeness, risk-taking, and autonomy. This study takes a bigger step and develops a profile model of firm-level entrepreneurship, one which incorporates the most popular and perhaps more relevant constructs of entrepreneurship. It can be recognized from other profiling studies by selecting a narrower (focusing only on the context of entrepreneurship) but deeper point of concentration (paying attention to both attitudes and behaviors).

The first cluster of the model - the non-entrepreneurial profile - is devoted to companies that show a low degree of both EO and CE. These companies suffer from a lack of orientation, which causes them to have no new entries. Small business owners (SBOs) of the start-up entrepreneurship literature seem a very close counterpart to this profile. Carland et al. (1984) described SBOs as individuals who see their business as the extension of their personalities, and as a means to support their families. They never intended to grow beyond a particular level (Vesper, 1990), and their highest priority is to balance their business/personal life (Fischer, Reuber, \& Dyke, 1993). They show a low 
tendency toward innovation, and aim only at a positive cash flow to simply remain in business (Runyan, Droge, \& Swinney, 2008). In the perspective of start-up entrepreneurship, latent (sometimes called nascent) entrepreneurs are people, who are distinguished by their declared preference for self-employment (Blanchflower, Oswald, \& Stutzer, 2001; Grilo \& Irigoyen, 2006). They may or may not have an actual plan to become self-employed (Grilo \& Irigoyen, 2006). This concept is usually referred to as the early stage of the entrepreneurship process (Brixy, Sternberg, \& Stuber, 2012). By expanding this notion to firm-level entrepreneurship, the latent entrepreneurial profile is characterized as newly established firms which have a massive inclination to being entrepreneurial, but do not show a high level of entrepreneurial action because of the barriers that newly established companies may face.

The third profile of the model is commonly called "forced entrepreneur" in the start-up entrepreneurship literature (Hughes, 2006; Orhan \& Scott, 2001). The key difference between forced and actual entrepreneurs - the last profile of the model - is their motivation to run a business. While forced entrepreneurs are pushed by external factors, actual entrepreneurs are pulled to start their own business (Hughes, 2006; Orhan \& Scott, 2001). In fact, the concepts of forced and actual entrepreneurs point to the "push" and "pull" incentives behind the decision to start a business (Hughes, 2006; Moore \& Mueller, 2002). Push factors are negative incentives that force people to start a business, such as redundancy, unemployment, lack of work opportunities, job loss and job insecurity. Pull factors, in contrast, are positive incentives that attract people to become entrepreneurs like independence, increased earnings and opportunities to carry out personal ideas (Hughes, 2006; Kautonen \& Palmroos, 2009). Forced entrepreneurs are pushed into entrepreneurship because they have no other way to provide for their cost of living (Bosma \& Harding, 2007).

The concepts of "forced" and "actual" entrepreneurship are assort with Sathe's (1988) notion of "surface" and "deep" entrepreneurship. Surface entrepreneurship points to the patterns of entrepreneurial activities that are recognized as important by management and are accomplished by organizational planning, while deep entrepreneurship returns to the patterns of entrepreneurial activities, which are inspired by 
shared organizational values. In forced entrepreneurial companies, the surface entrepreneurial pattern is dominant, and may be enforced by external factors such as networks, binding contracts, environmental threats, and so on. The dominant pattern of entrepreneurial activities in actual entrepreneurial firms is the deep entrepreneurship that mainly originates from shared values and flows through all organizational levels.

This profile model is perfectly matched with this study's definition of entrepreneurship as a combination of exploration and exploitation of opportunities. Exploration deals with acquiring knowledge, while exploitation is mainly focused on the implementation of knowledge in an organization (March, 1991). EO and CE cover the exploration and exploitation of entrepreneurial opportunities, respectively (Kuratko et al., 2004). Usually, the returns of exploitation compared to the returns of exploration are more certain, more near in time, and need less organizational actions and adaptations (March, 1991); therefore, forced entrepreneurial companies struggle more with exploitation that is a fairly good match with their surface pattern of entrepreneurship. On the other hand, deep entrepreneurship is more in accordance with a balanced mode of exploration and exploitation, and is a better fit with actual entrepreneurial companies.

Separating exploration and exploitation does not really mean that entrepreneurship can be exist in one of those forms. Actually, this study has agreed with researchers who state that exploration and exploitation are inseparable and internally integrating phenomena that form a synergic interdependence together (Boso, Cadogan, \& Story, 2012a; Raisch \& Birkinshaw, 2008). Having exploration on the one hand and exploitation on the other is just a way to describe differences between forced and actual entrepreneurial companies: the first is more inclined toward exploitation, while the second maintains a balance between exploration and exploitation. Auh and Menguc (2005, p. 1653) described this argument in clear statements;

Excessive exploration at the expense of exploitation can be costly, as the tangible outcomes of exploration will only be realized in the distant future and then only with considerable uncertainty. On the other hand, a concentration on exploitation without exploration discourages the organization from pursuing learning and development. This can direct firms 
to focus only on the near future and potentially miss out on long-term investments and opportunities that may prove valuable. There is a sense that firms need to identify a well-balanced combination of exploitation and exploration strategies.

In the aggregate, actual entrepreneurial companies maintain a balance between exploration and exploitation, forced entrepreneurial firms are more in favor of exploitation, and latent entrepreneurial companies are new startups, which explore and identify entrepreneurial opportunities but do not have access to the required resources, information, networks, and so on to exploit them.

\subsection{Firm-Level Entrepreneurship and Internationalization}

The RBV is recommended as a theory that is able to answer the key questions about how SMEs can successfully accelerate their internationalization without going through different steps, as suggested by the stage models (Peng, 2001). In a systematic review of the RBV studies of international business, Peng (2001) concluded that SMEs or start-up businesses are not able to compete with large multinational companies on the basis of tangible resources; instead, they should focus on "intangible resourcefulness, that is, the ability of doing more with less" (p. 818). Firm-level entrepreneurship is considered a major intangible resource of SMEs that is rare, valuable, inimitable, and non-substitutable. It assists companies to achieve competitive advantage in international markets (Yamakawa, Peng, \& Deeds, 2008; Zhang, Tansuhaj, \& McCullough, 2009) through exploration and exploitation of new opportunities (Garcia-Morales, Bolivar-Ramos, \& Martin-Rojas, 2014; Peng, 2001). Looking at firm-level entrepreneurship as a resource that allows companies to compete in international markets (Zahra \& George, 2002) and to create value in early internationalization through promoting competitive advantage (Zahra, 2005) is a common application of the RBV in international entrepreneurship.

The RBV is frequently applied to study the relationship of firm-level entrepreneurship and performance (internationalization) both conceptually (e.g. Covin \& Slevin, 1991; Dess et al., 1999; Jones \& Coviello, 2005; Lumpkin \& Dess, 1996a; Zahra, 2005) and empirically (e.g. Covin \& Slevin, 1989; Lumpkin \& Dess, 2001; Wiklund \& 
Shepherd, 2005). Conceptual studies are designed to describe the nature of the relationship by developing the theoretical models of influential factors and conditions, while empirical studies aim at testing those models in practice.

Conceptual studies have justified the interrelation of firm-level entrepreneurship and internationalization in different ways. First, they discuss the benefits of the lower dimensions of firm-level entrepreneurship: self-renewing generates new capabilities (Zahra, 1991), while venturing leads to new streams of revenue (Guth \& Ginsberg, 1990) that improve the competitive position of a company (Zahra, Neubaum, \& Huse, 2000) and lead to superior performance. Having an innovative and effective global strategy helps companies to survive and successfully compete in foreign markets (Zahra et al., 2001). Second, they describe internationalization as an entrepreneurial phenomenon: entrepreneurship and internationalization are interwoven in such a way that the decision to internationalize (Sapienza, Autio, George, \& Zahra, 2006), and the subsequent activities of internationalization are considered to be specific forms of firm-level entrepreneurship (Zahra, Neck, \& Kelley, 2004; Zahra et al., 2013b). A new entry is commonly defined as a form of entrepreneurship (Lumpkin \& Dess, 1996b); thus, entering an international market with a new cultural context and novel costumer demands can certainly be regarded as a sort of entrepreneurship. Third, they count entrepreneurship as an important factor of early internationalization: firm-level entrepreneurship is a determinant of both initiation and subsequent outcomes of early internationalization (Jones \& Coviello, 2005), and helps companies to explore and exploit opportunities in international markets (McDougall \& Oviatt, 2000; Mcdougall, Shane, \& Oviatt, 1994; Oviatt \& Mcdougall, 1994; Weerawardena, Mort, Liesch, \& Knight, 2007). Proactiveness - a specific dimension of firm-level entrepreneurship - augments international activities via changing a firm's marketing mix, helps companies to quickly adapt with psychologically distant markets, and plays a crucial role in encouraging companies to become involved in international markets (Czinkota \& Johnston, 1981; Katsikeas \& Piercy, 1993).

A massive body of empirical research exists, which has provided enough material to perform two meta studies to date. The first study, conducted by Rauch et al. (2009) (51 studies from 14 countries with $\mathrm{N}=14259$ ), revealed a significant, positive and moderately 
large relationship (correlation coefficient of .242) between EO and performance. This relationship remained robust under different conceptualization, operationalization, and cultural contexts, and even under different external or internal conditions. The second, carried out more recently by Saeed, Yousafzai, and Engelen (2014) (177 studies from 41 countries with $\mathrm{N}=47140$ ) also showed a moderately large, significant association between EO and performance (correlation coefficient of .268). This association was stronger among companies in developing rather than developed countries that enjoy more political stability. Moreover, a systematic literature review by Wales et al. (2011) echoed similar results. In general, meta studies revealed an aggregate conclusion of the significant relationship between $\mathrm{EO}$ and performance.

The aforementioned meta-analyses and literature reviews assist the field by summarizing and proposing the aggregate conclusions of existing empirical and conceptual studies, but relying on those studies alone, especially in this research, could be misleading for several reasons. First, they mainly place their attention on a few major journals and disregard a number of studies that have been published in less popular ones. Unfortunately, the majority of research performed in undeveloped, developing, and even emerging countries is published in less popular journals (e.g. Hosseini \& Eskandari, 2013; Kaya, 2006; Li, Zhang, \& Chan, 2005). Second, entrepreneurial orientation is the major concern of those studies; therefore, they leave unnoticed a part of literature which applies other measurements of firm-level entrepreneurship. Third, a fairly large body of research has emerged since those studies have been published that are not counted in their aggregate conclusions. Fourth, and more importantly, they have summarized the effect of firm-level entrepreneurship on corporate performance, while the main interest of this study is the influence of entrepreneurship on internationalization. Therefore, conducting a new literature review that compensates for these deficiencies is required. For this research, 128 empirical studies of firm-level entrepreneurship were selected based on a systematic search in online databases, through both key word searching and cross-referencing techniques. Among all the selected papers (Table 2-3), 61 focused on corporate performance and 67 ( 8 papers were qualitative and excluded from the aggregate analysis) studied the relationship of firm-level entrepreneurship and internationalization. 


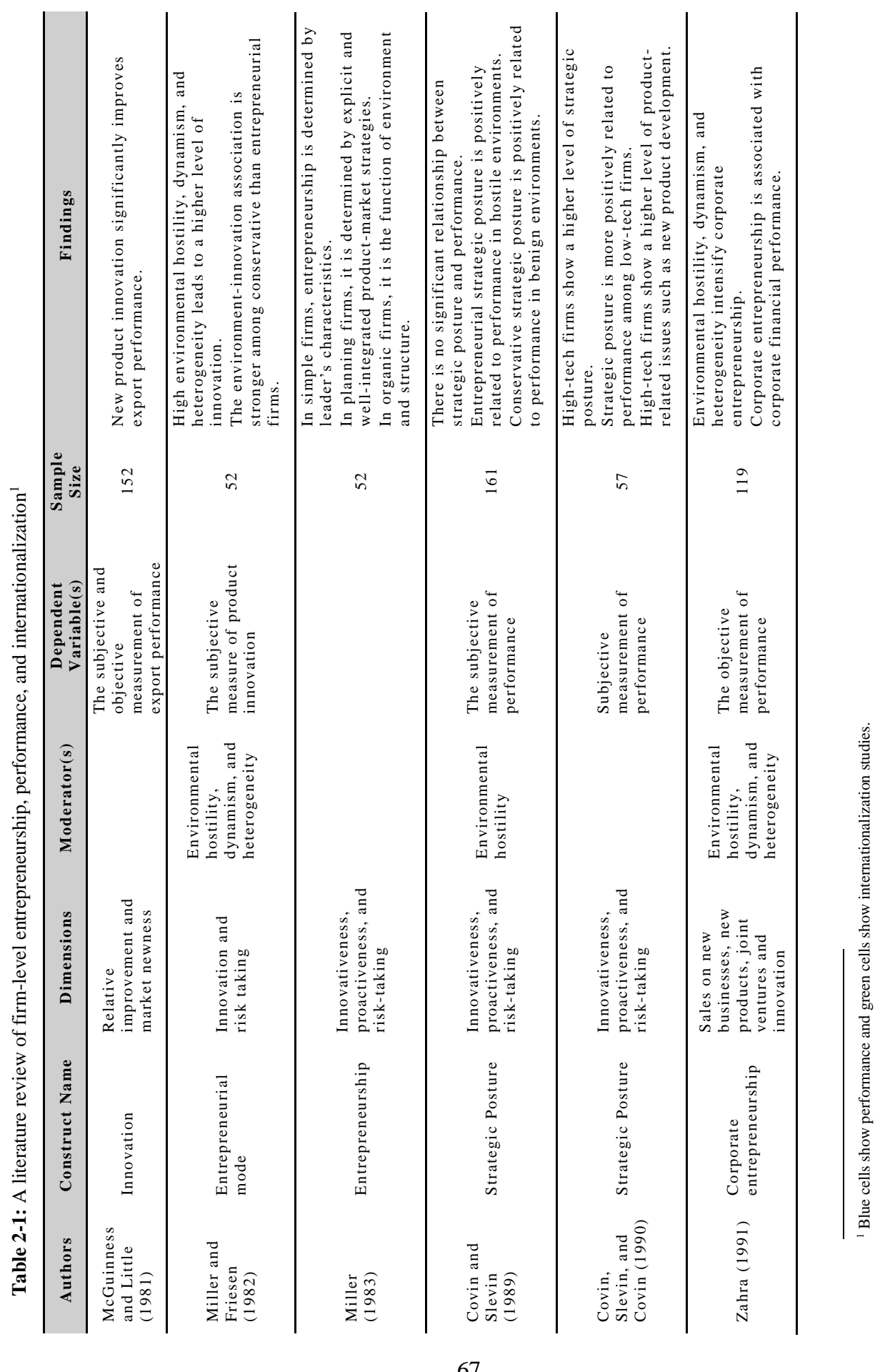




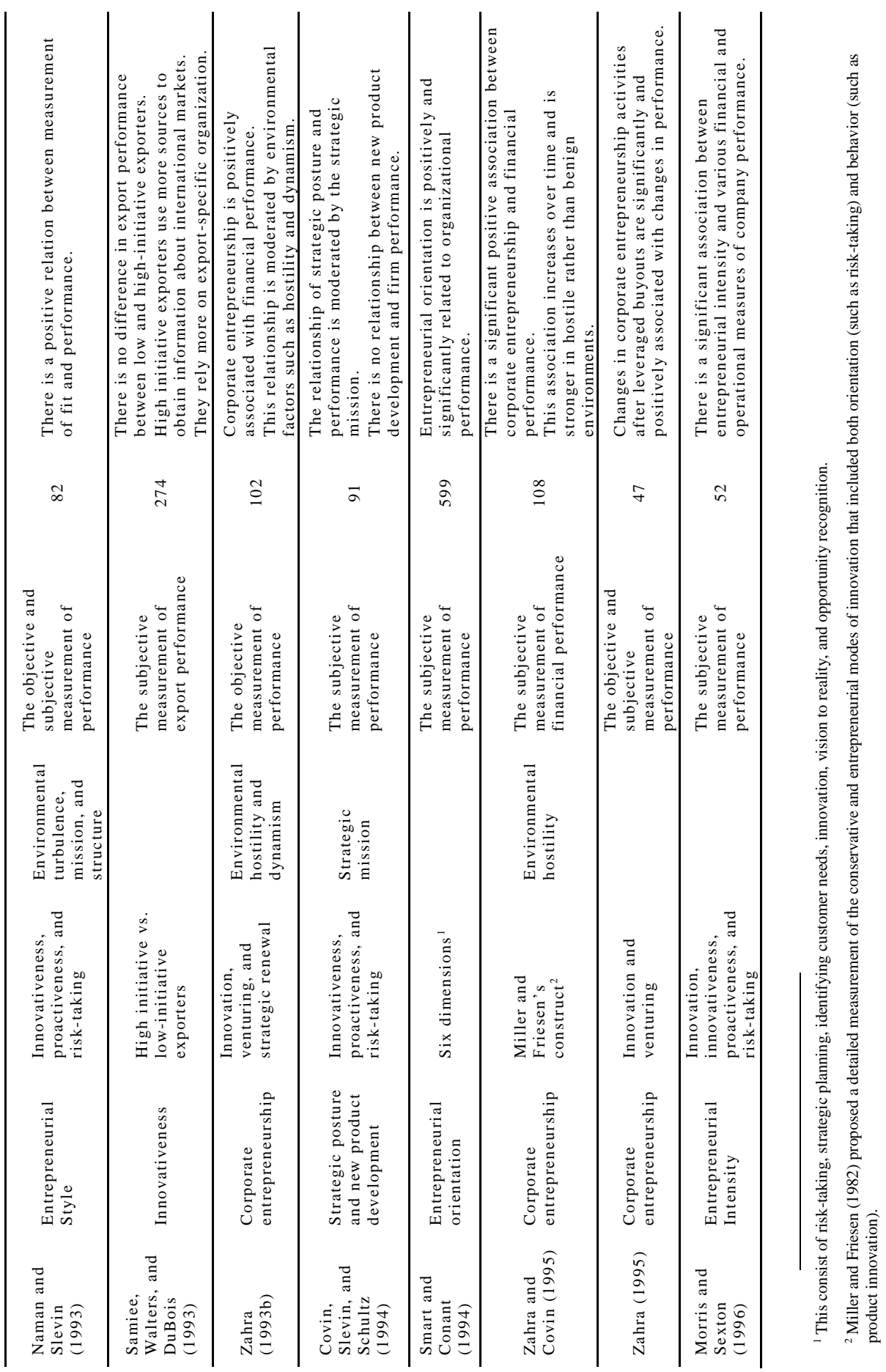




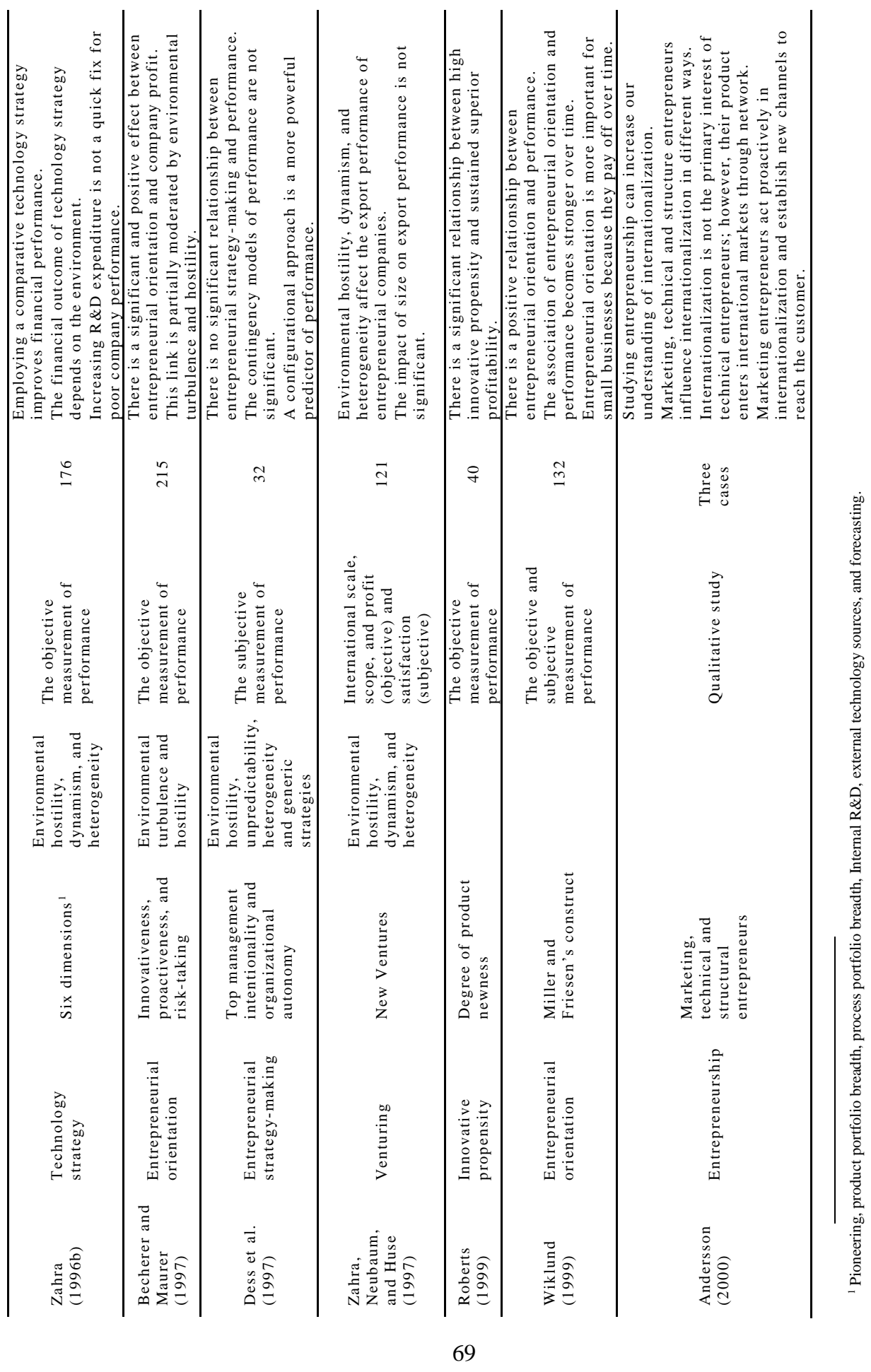




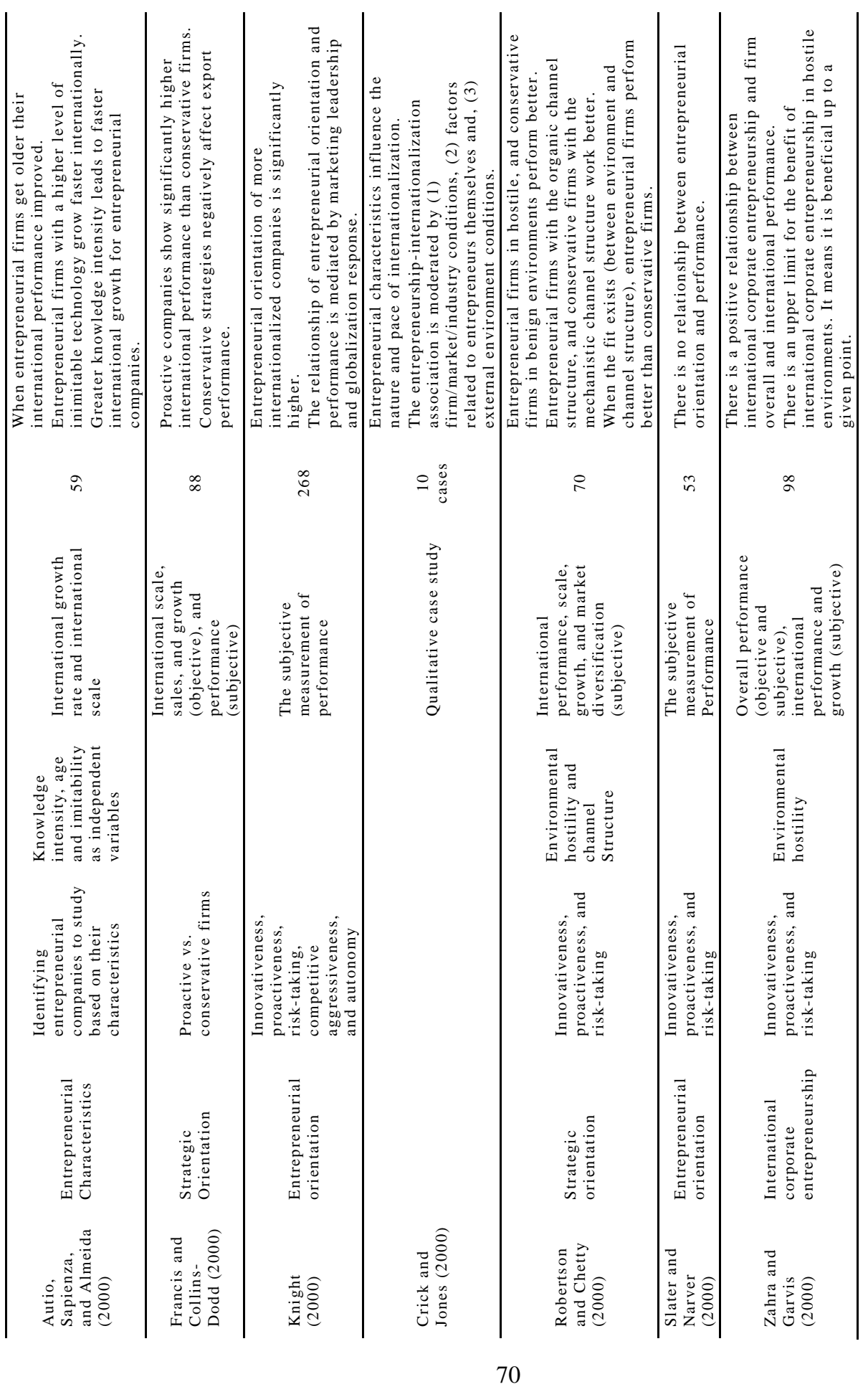




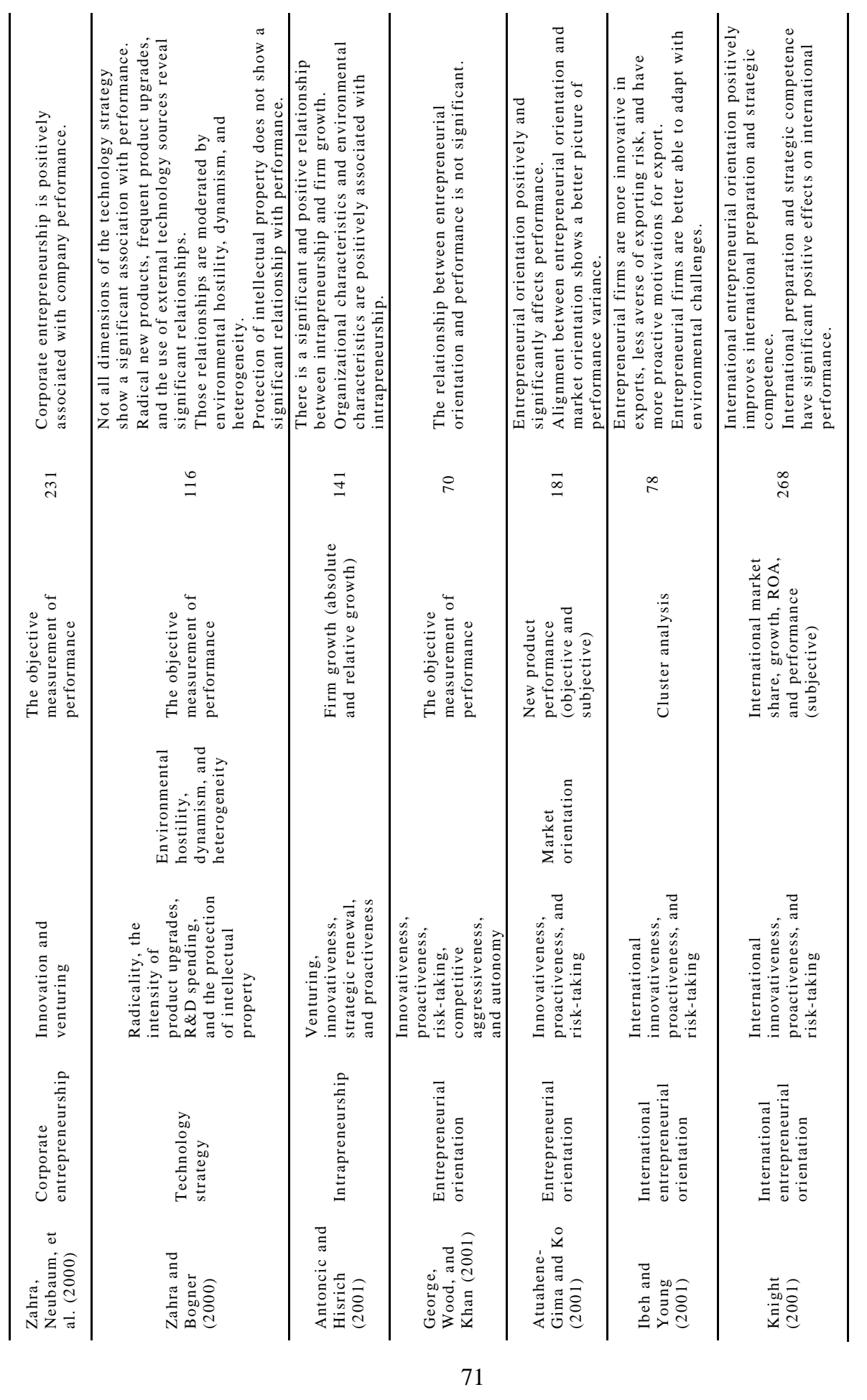




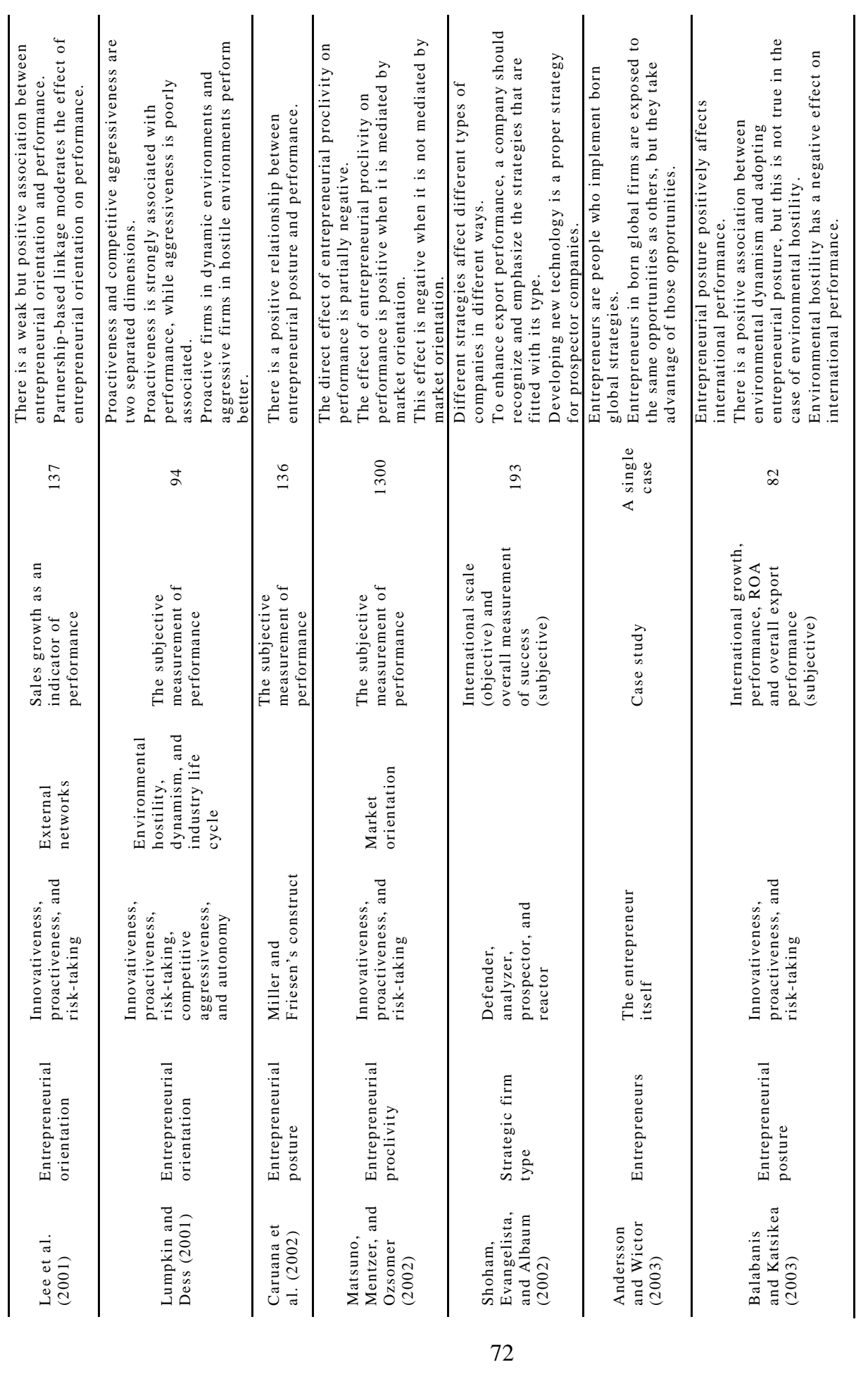




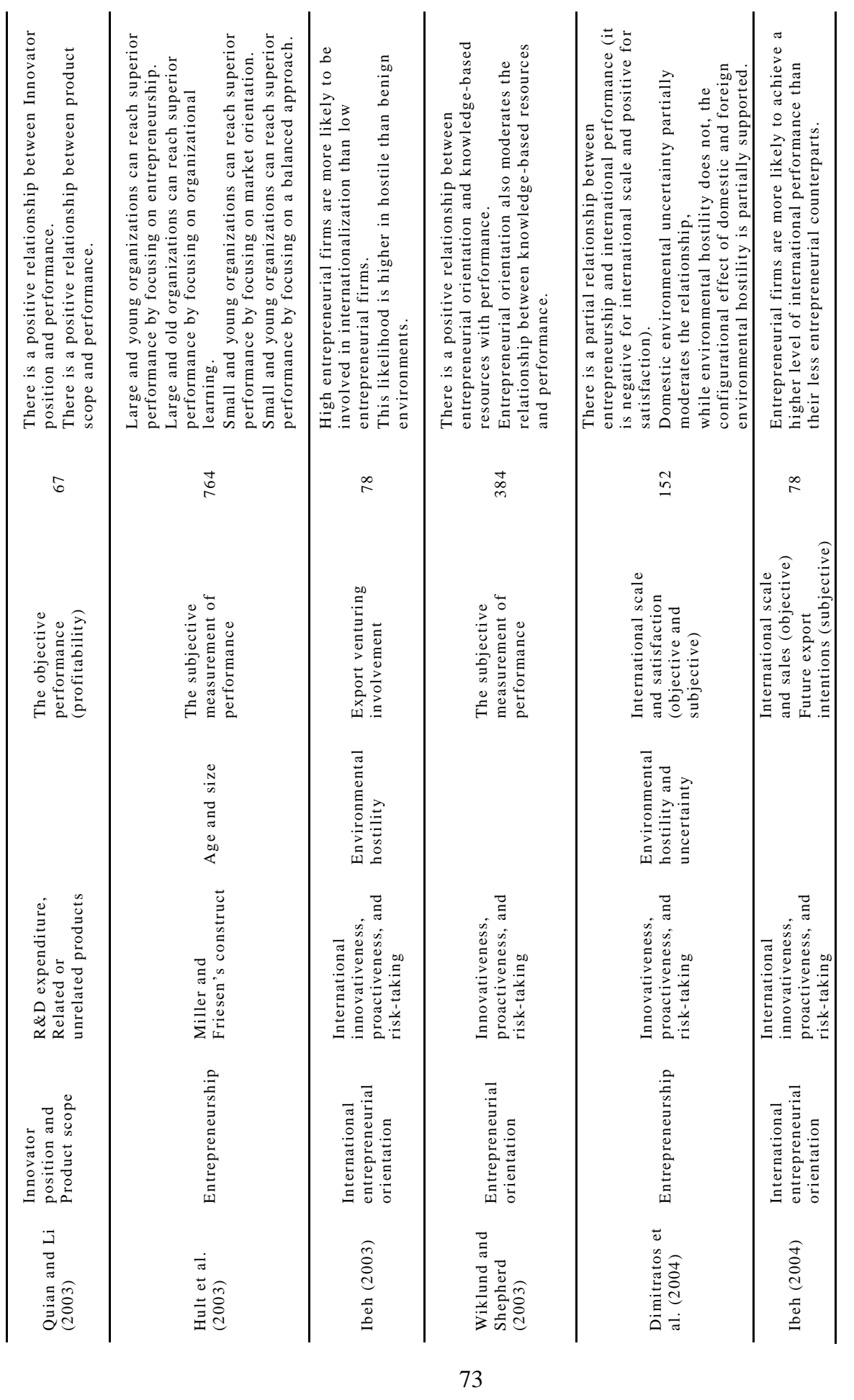




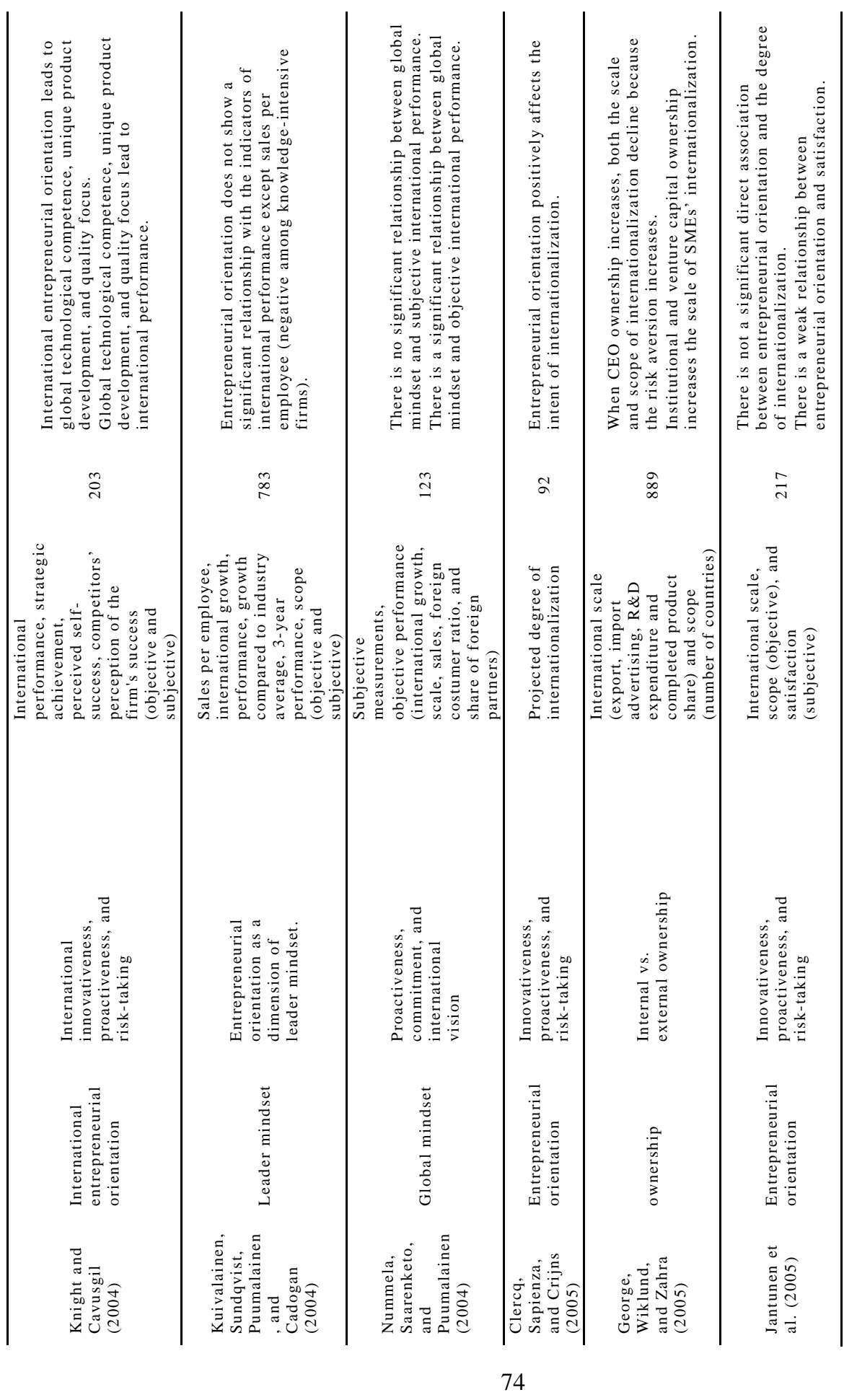




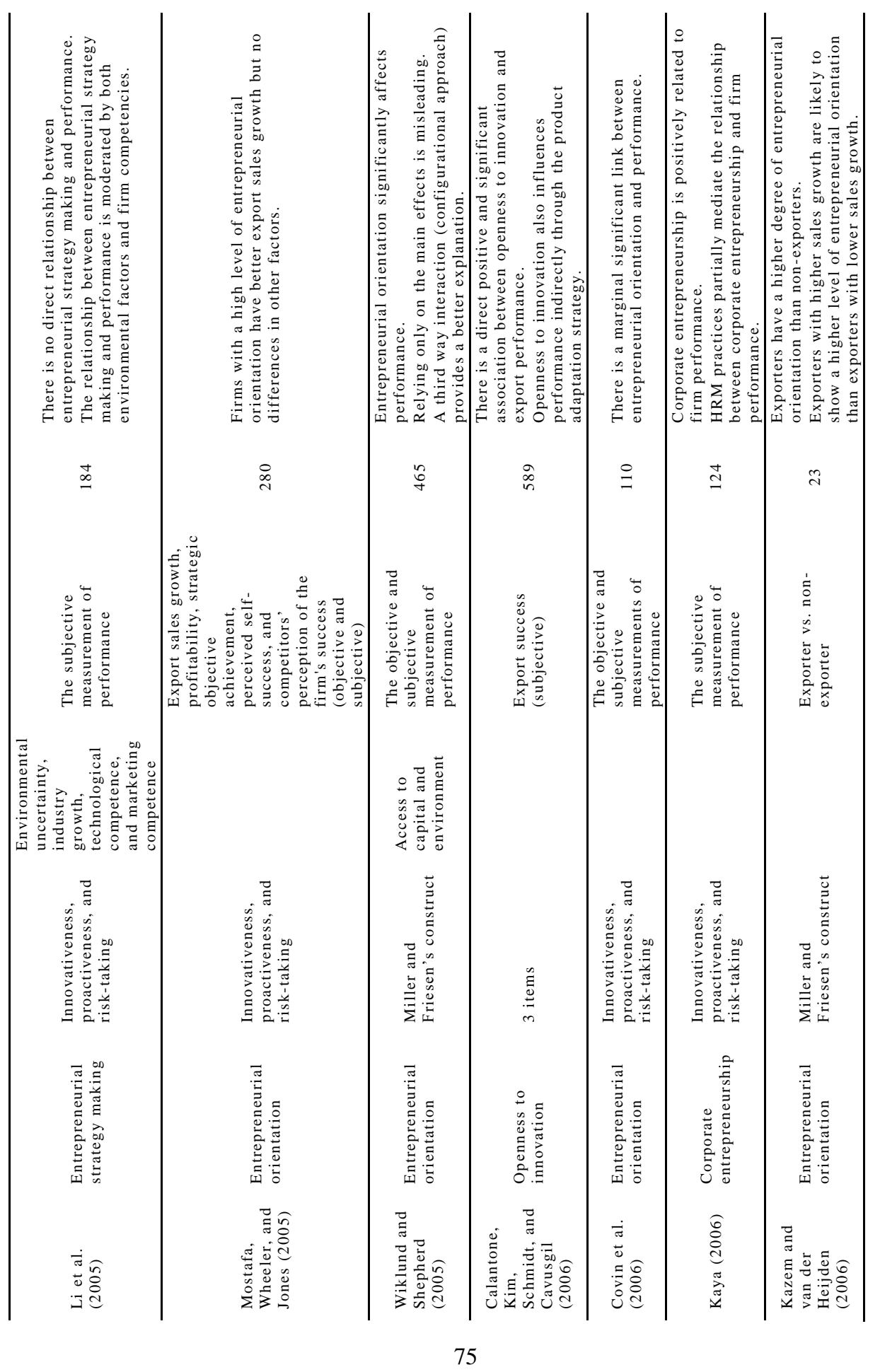




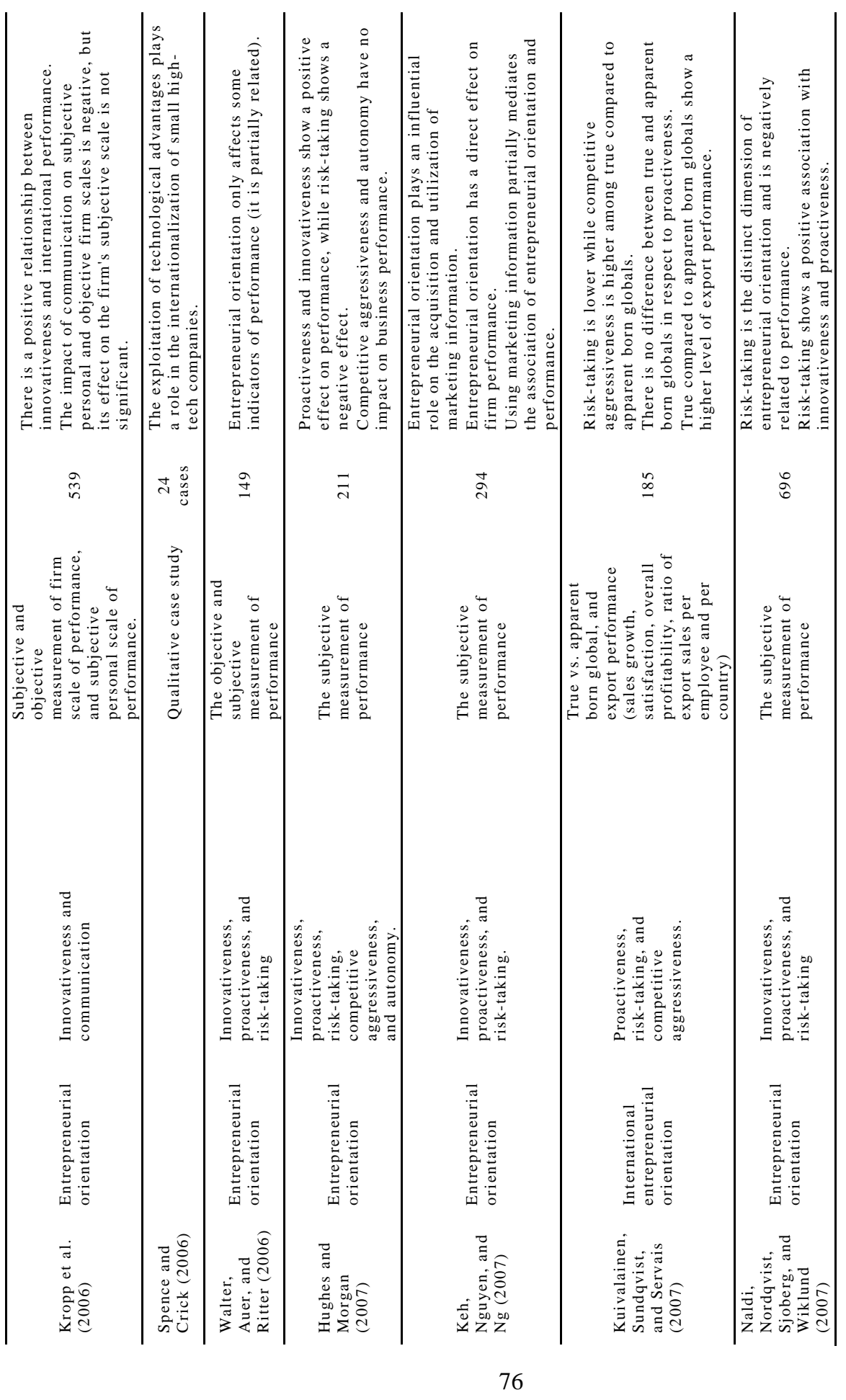




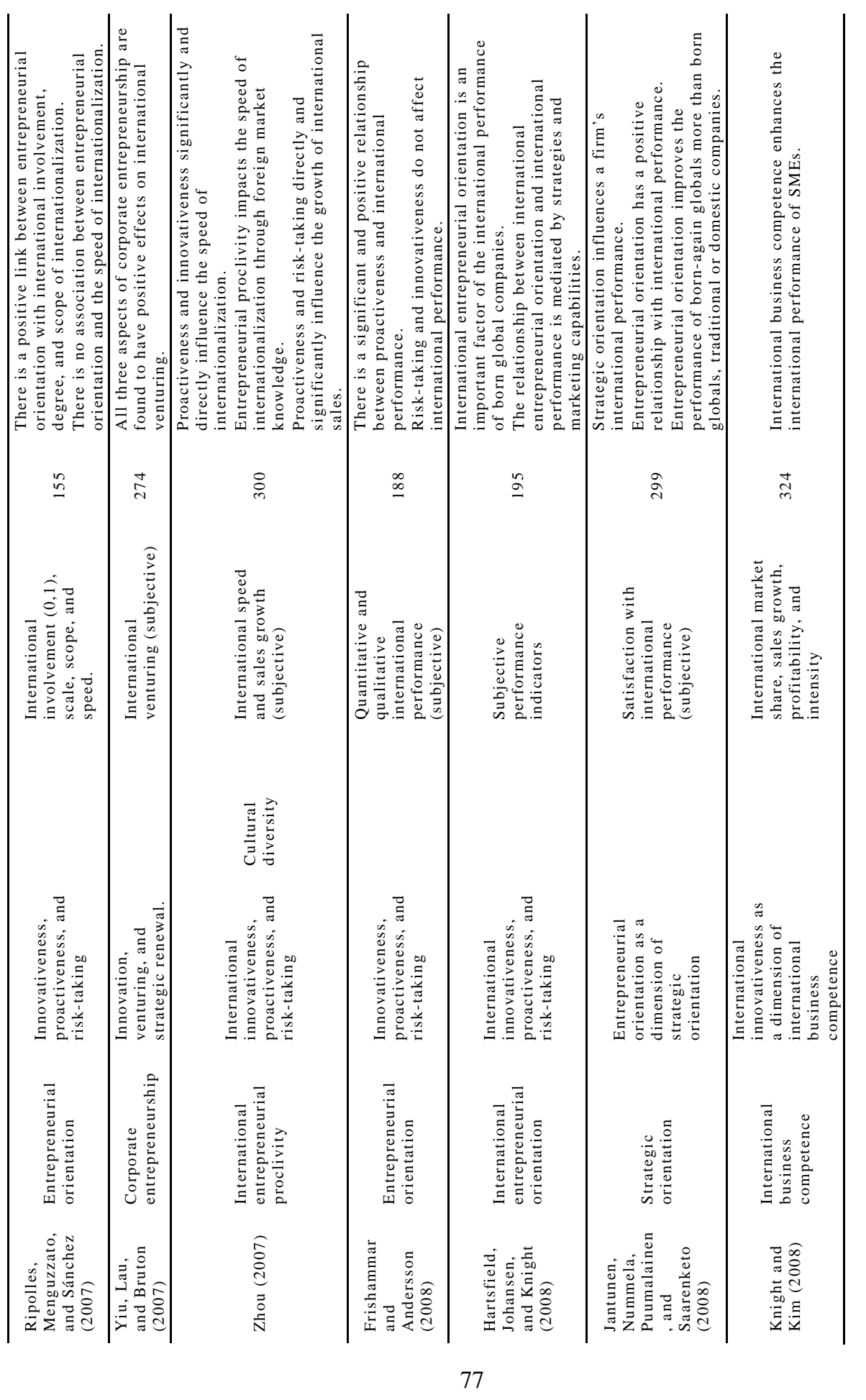




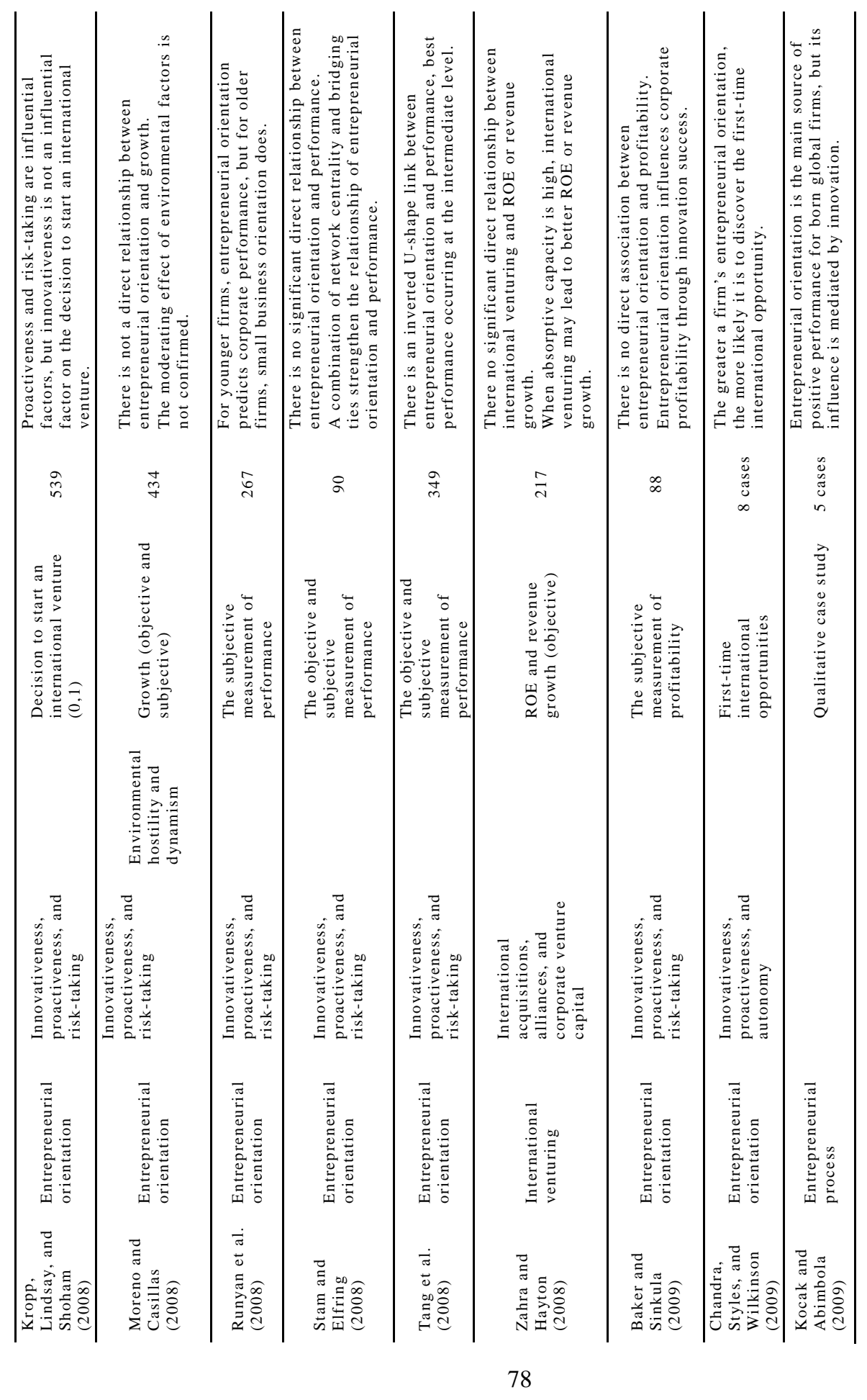




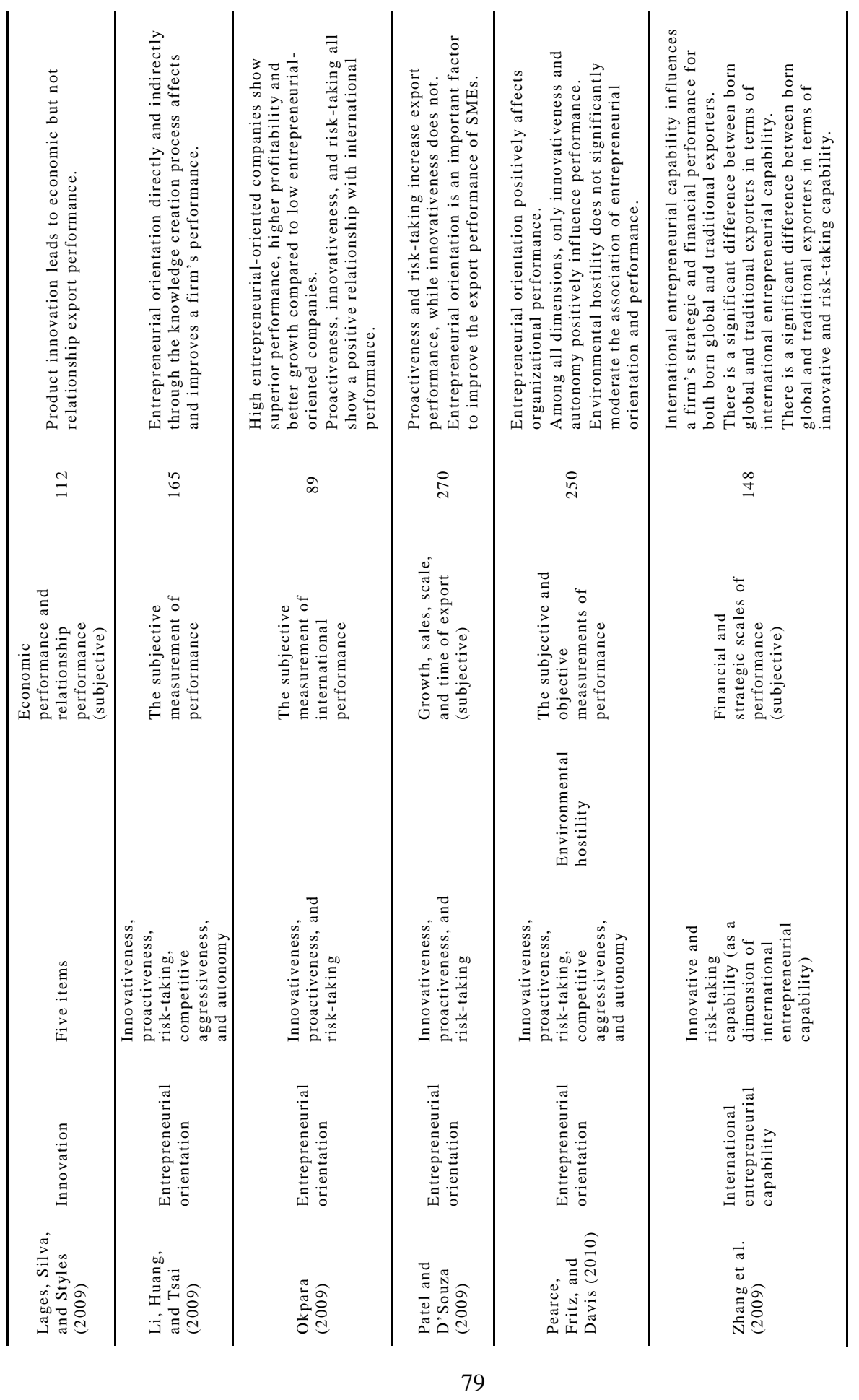




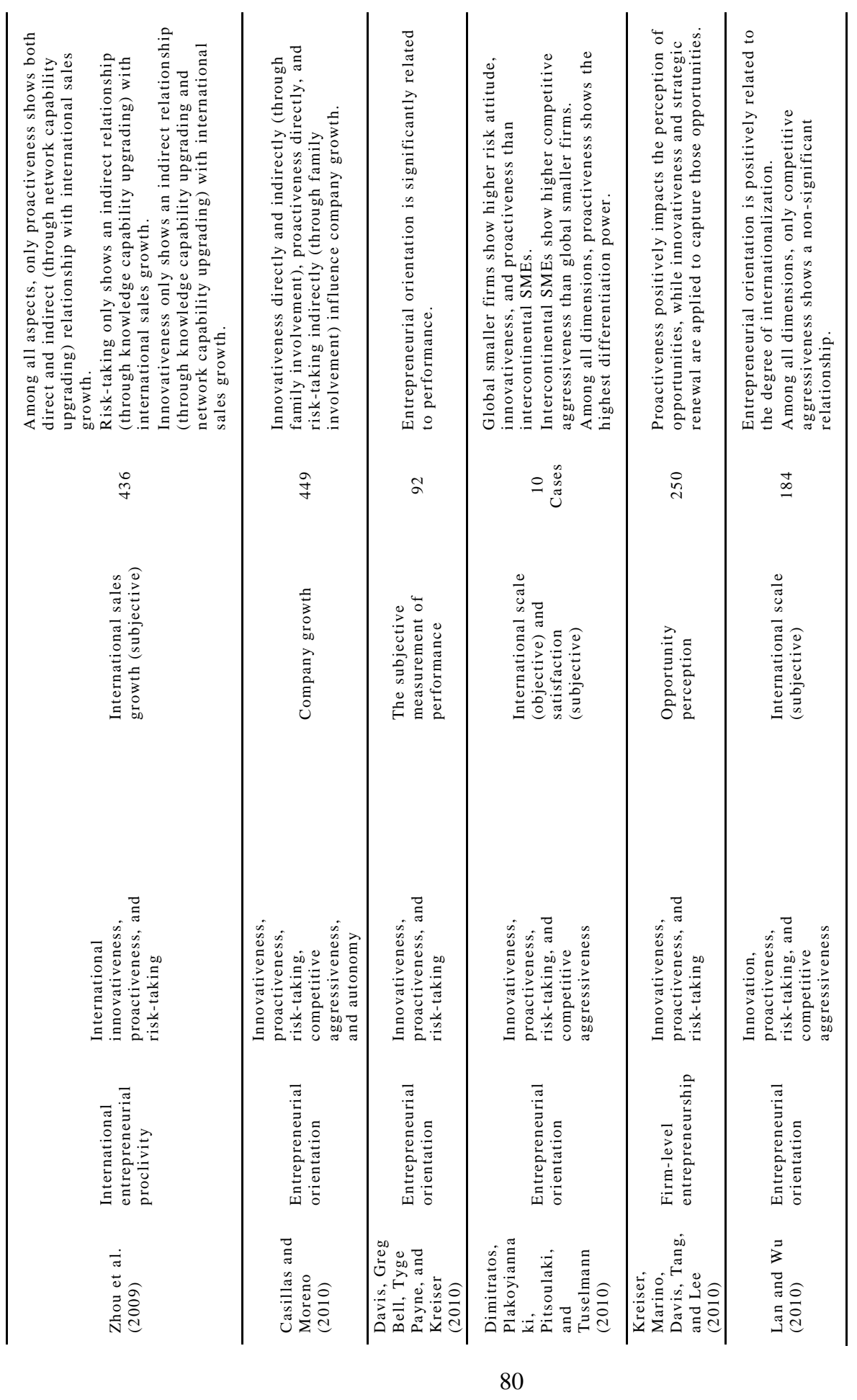




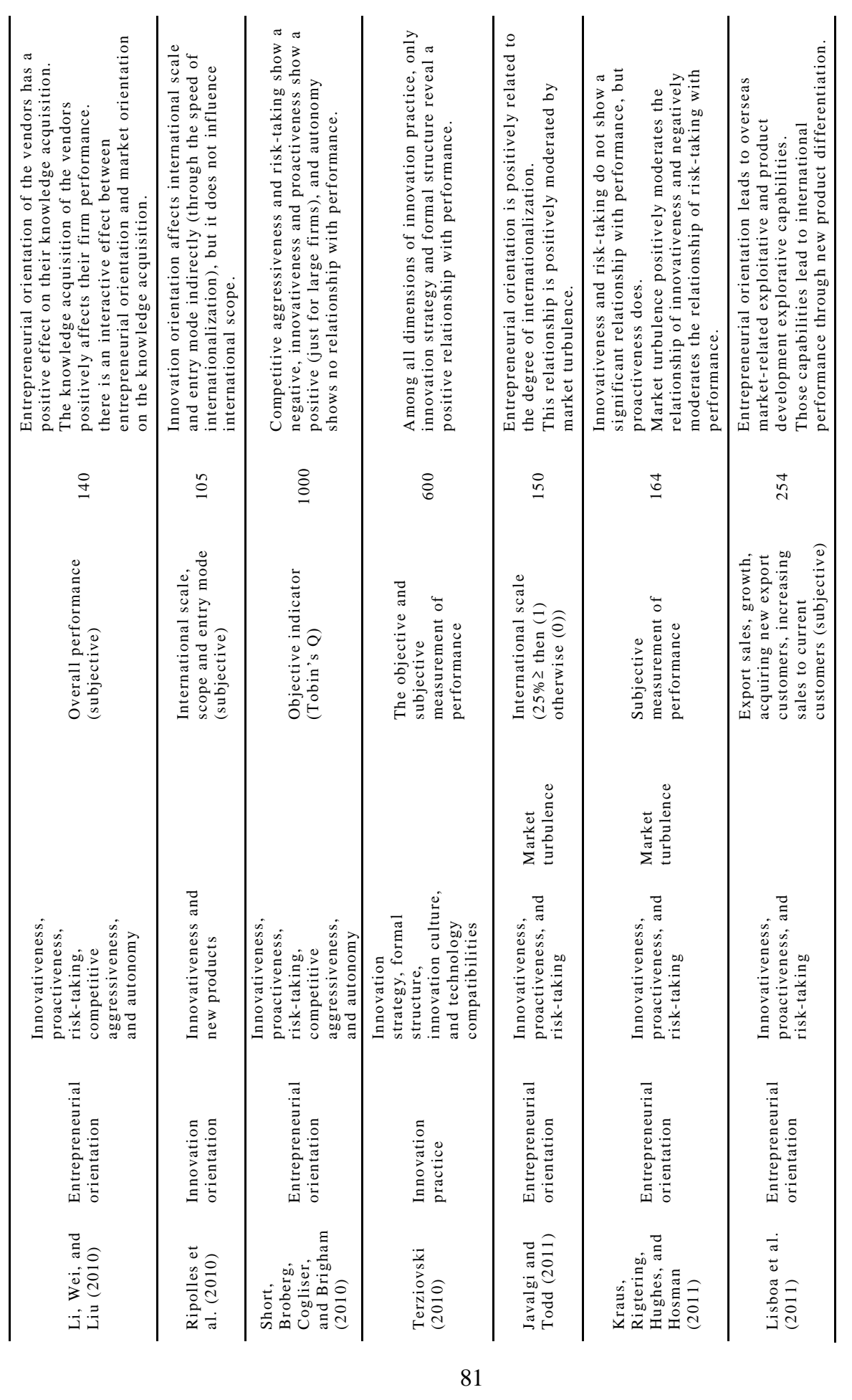




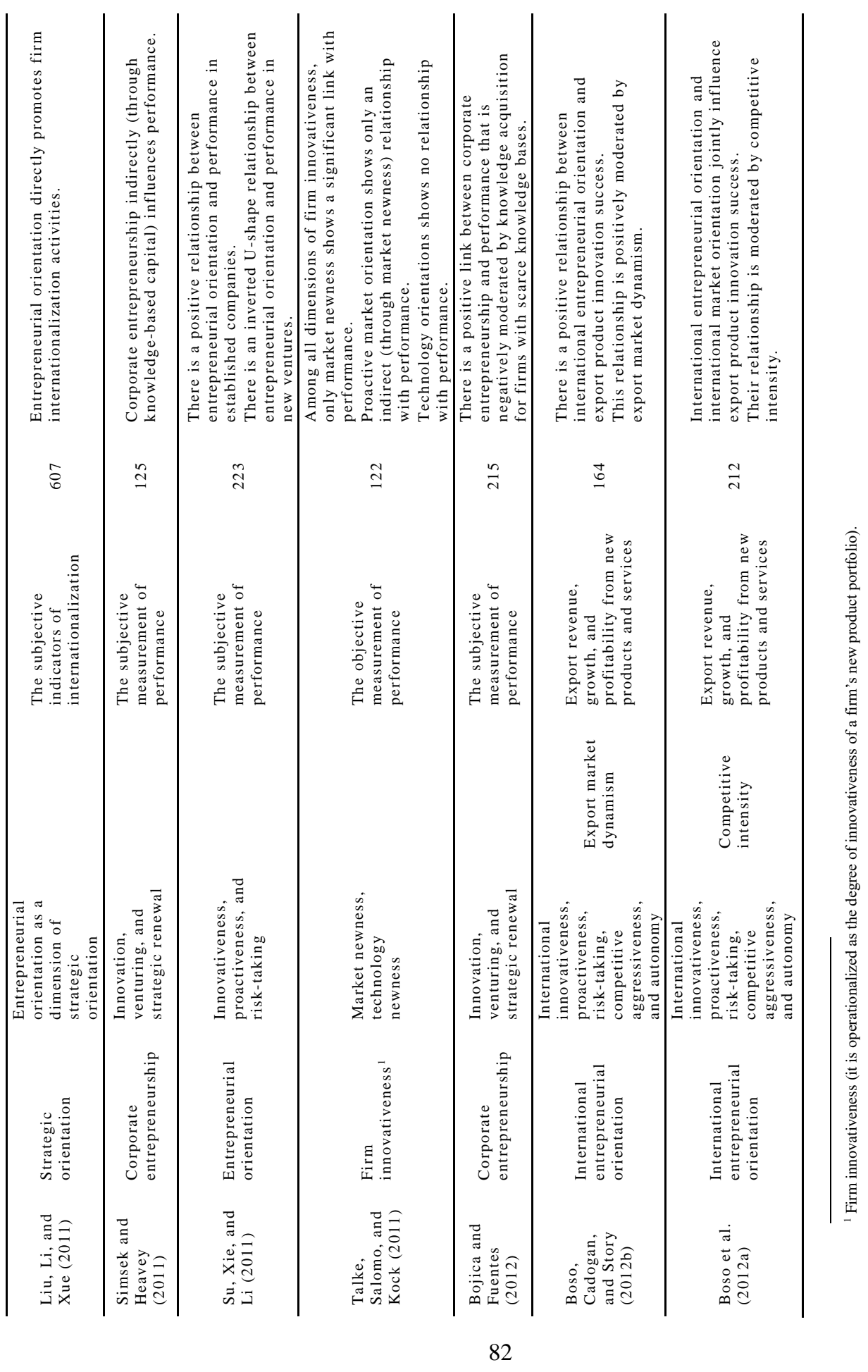




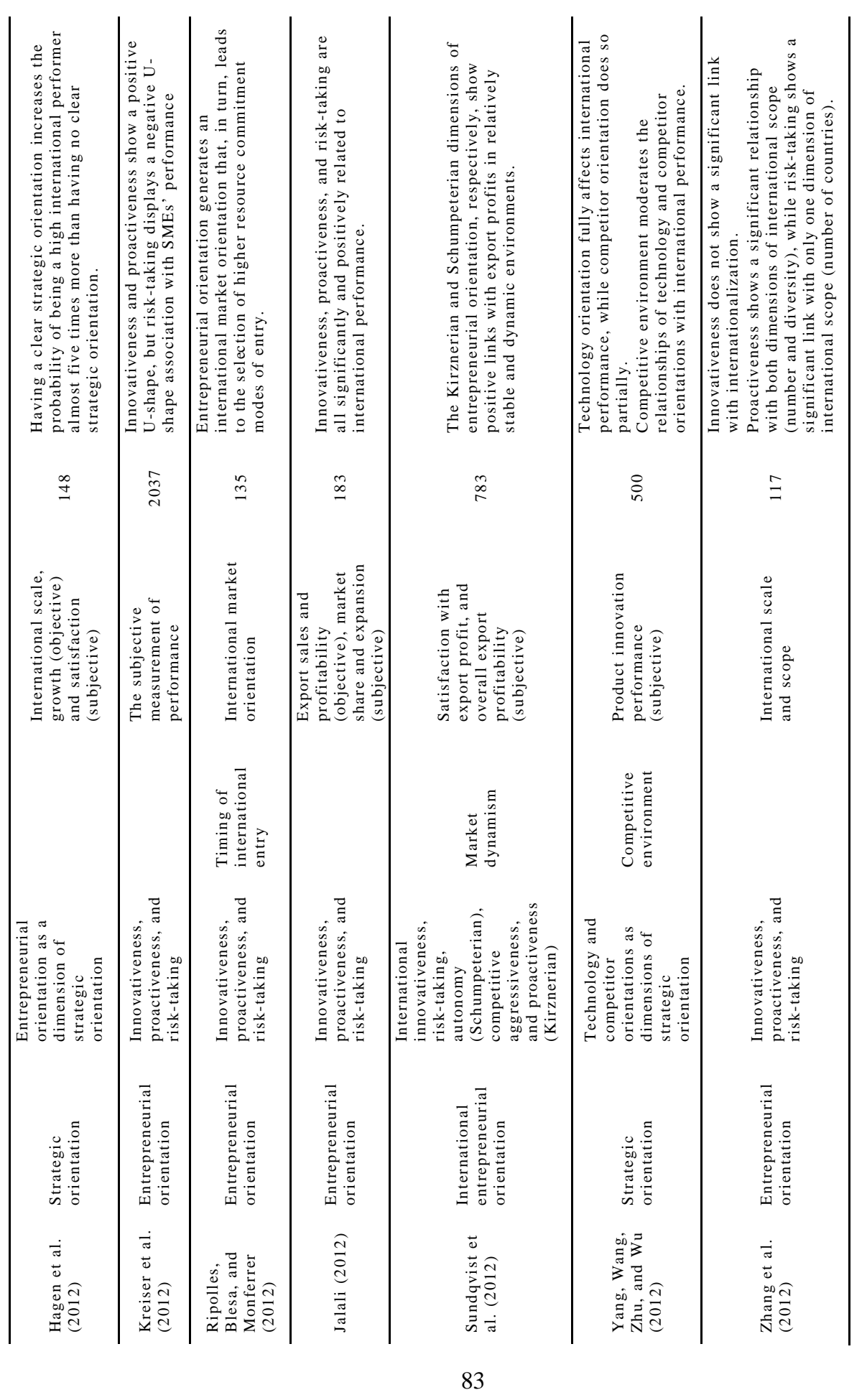




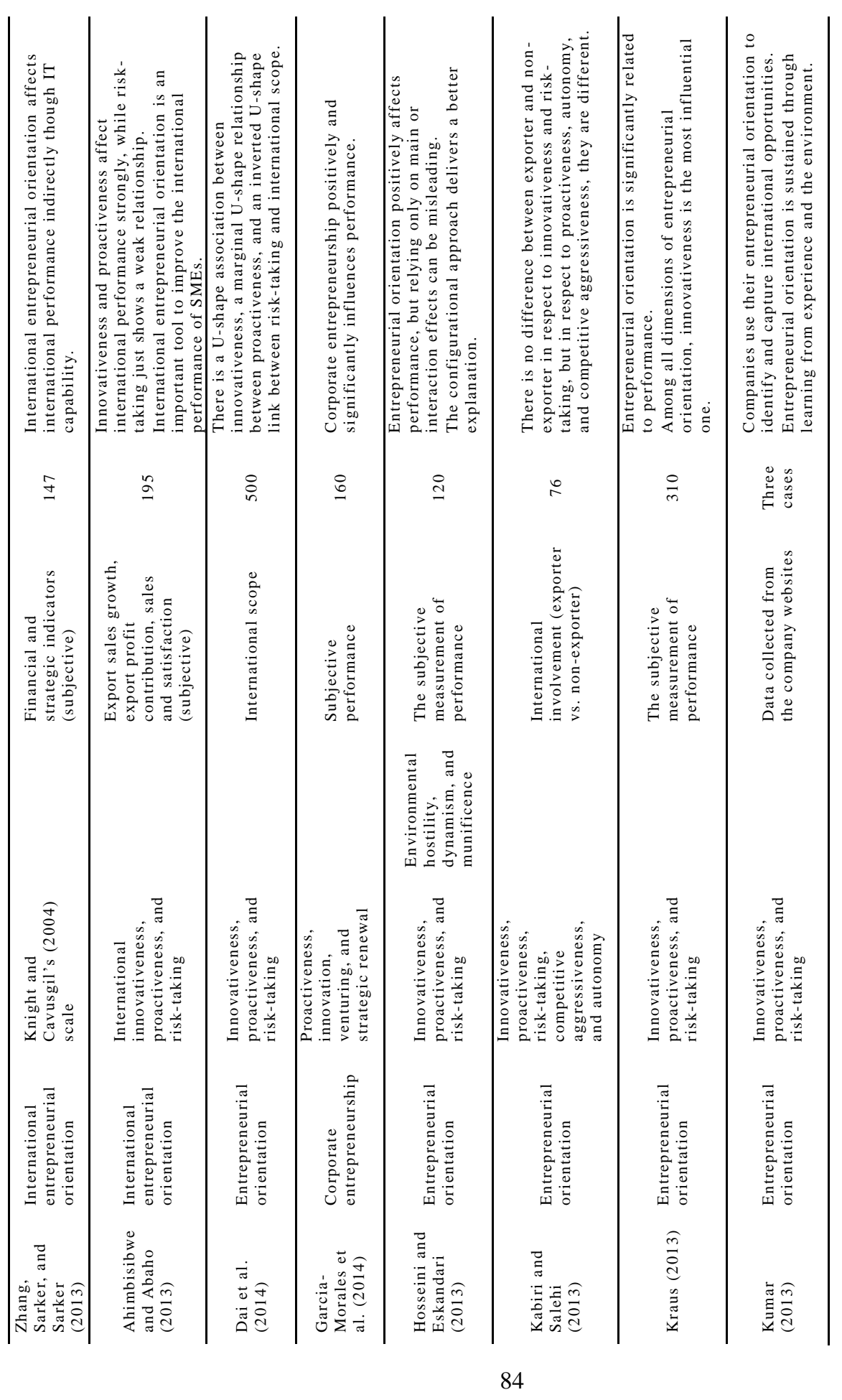




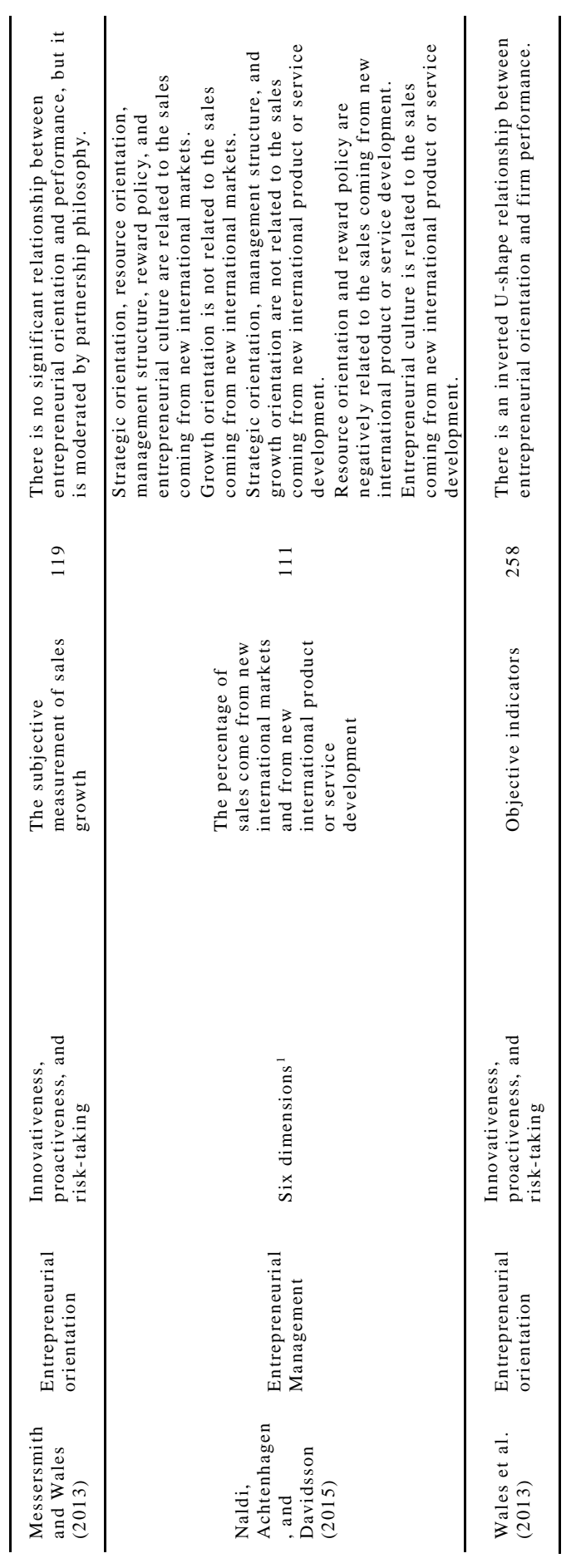

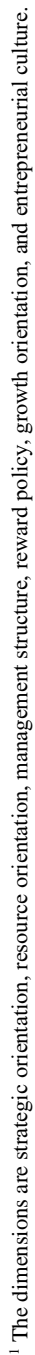


As this review shows, different terms and expressions have been used to name the orientation $^{1}$, the behavior ${ }^{2}$, or a combination of both ${ }^{3}$. A very simple analysis of the frequency of the reviewed papers reveals EO and CE as the most frequently used expressions to respectively call the orientation and behavior of firm-level entrepreneurship in both performance and internationalization studies. Empirical studies are also very inconsistent in the number of dimensions that they have implemented to measure the phenomenon. While some studies employ a three or more-than-three dimensional construct (e.g. Antoncic \& Hisrich, 2001; Garcia-Morales et al., 2014; Sundqvist et al., 2012), there are others that use a less-than-three dimensional measurement building upon two or even one indicator (e.g. McGuinness \& Little, 1981; Roberts, 1999; Samiee et al., 1993).

A major part of the research on internationalization has examined the effect of firm-level entrepreneurship on international scale and scope. With the exception of a few studies, other dimensions of internationalization such as the speed or the decision to enter a foreign market have been rarely studied (e.g. Ripolles et al., 2010; Ripolles et al., 2007; Zhou, 2007). Almost all papers that inspect the influence of entrepreneurship on companies' involvement in international markets disclose a significant (Chandra et al., 2009; Ibeh, 2003; Kazem \& van der Heijden, 2006; Ripolles et al., 2012; Ripolles et al., 2007) or at least a partially significant (Kabiri \& Salehi, 2013; Kropp et al., 2008) relationship. These empirical conclusions are in accordance with the RBV theory, which discusses firm-level entrepreneurship as a featured resource that helps companies to

\footnotetext{
${ }^{1}$ Examples include entrepreneurship (Dimitratos et al., 2004; Hult et al., 2003; Miller, 1983), strategic posture (Covin \& Slevin, 1989; Covin et al., 1990), entrepreneurial style (Naman \& Slevin, 1993), entrepreneurial orientation (Dai et al., 2014; Knight, 2000; Wales et al., 2013; Wiklund, 1999), corporate entrepreneurship (Kaya, 2006; Zahra \& Covin, 1995; Zahra \& Garvis, 2000), entrepreneurial strategy making (Dess et al., 1997; Li et al., 2005), entrepreneurial characteristics (Autio et al., 2000), strategic orientation (Francis \& Collins-Dodd, 2000; Robertson \& Chetty, 2000), and entrepreneurial posture (Balabanis \& Katsikea, 2003; Caruana et al., 2002; Zhou, 2007).

${ }^{2}$ Examples include corporate entrepreneurship (Garcia-Morales et al., 2014; Simsek \& Heavey, 2011; Yiu et al., 2007; Zahra, 1991; Zahra, Neubaum, et al., 2000), and Technology strategy (Zahra, 1996b; Zahra \& Bogner, 2000)

${ }^{3}$ Examples include entrepreneurial intensity (Morris \& Sexton, 1996), intrapreneurship (Antoncic $\&$ Hisrich, 2001), and firm-level entrepreneurship (Kreiser et al., 2010).
} 
effectively compete with domestic rivals. It is also in agreement with defining new entry as a form of entrepreneurship. Consequently, it can be concluded that:

Hypothesis 1: Among all types of companies, actual entrepreneurial firms are expected to show the highest level of international involvement.

As was anticipated, a large disagreement exists among empirical findings in terms of the influence of firm-level entrepreneurship on international scale and scope among both performance and internationalization studies. While the greater parts of corporate ( 28 articles) and international studies (33 articles) display a direct positive relationship between firm-level entrepreneurship, corporate and international performance, there are other papers that show a partial (24 articles of corporate and 21 articles of international performance) or no relationship (9 articles of corporate and 2 articles of international performance). A chi square analysis of corporate $\left(\mathrm{X}^{2}(2, \mathrm{~N}=61)=9.869, \mathrm{P}=0.007\right)$ and international performance $\left(\mathrm{X}^{2}(2, \mathrm{~N}=56)=26.179, \mathrm{P}=0.000\right)$ indicates that the number of studies that confirm a link between firm-level entrepreneurship and corporate or international performance is significantly greater than those which could not find such a relationship. Again, the empirical studies support the theoretical explanation of the RBV, which defines firm-level entrepreneurship as a source of competitive advantage leading to performance superiority. Therefore:

Hypothesis 2: Among all types of companies, actual entrepreneurial firms are expected to show the highest level of international scale.

Hypothesis 3: Among all types of companies, actual entrepreneurial firms are expected to show the highest level of international scope.

Unfortunately, just three papers in the review have studied the effect of the speed of internationalization, and their findings are very uncertain. Ripolles et al. (2007) could not find a significant link between firm-level entrepreneurship and the speed of internationalization, but Zhou (2007) found a partial connection and Ripolles et al. (2010) confirmed a significant positive relationship. Consequently, the empirical studies in this review are not adequate to have an aggregate conclusion on the speed of internationalization. However, in reference to (1) defining entrepreneurship as the process 
of exploration and exploitation (Shane \& Venkataraman, 2000) that may help companies to identify international opportunities faster, (2) the principal debate of international entrepreneurship that proposes entrepreneurship as a fundamental mechanism to describe the phenomena of new international ventures and born global companies (Andersson \& Wictor, 2003; McDougall \& Oviatt, 2003; McDougall, Oviatt, \& Shrader, 2003; Mcdougall et al., 1994; Oviatt \& Mcdougall, 1994, 2005a, 2005b; Weerawardena et al., 2007; Zahra, 2005), and (3) in accordance with Acedo and Jones (2007) who introduced risk perception - a fundamental issue in entrepreneurship - as a fundamental explanation for the rapidity of first international market entry, it is reasonable to say:

Hypothesis 4: Among all types of companies, actual entrepreneurial firms are expected to show the fastest pace of internationalization.

As was demonstrated in this research and reiterated many times in the literature, there is an essential disagreement among empirical findings concerning the effect of firmlevel entrepreneurship on corporate or international performance; therefore, answering the question of why this inconsistency exists is timely and worth to taking into consideration. Using different indicators to measure corporate performance (Hughes \& Morgan, 2007; Lumpkin \& Dess, 1996b), applying the different measurements of firm-level entrepreneurship (as was discussed in detail before), and the contingency nature of the relationship (Lumpkin \& Dess, 1996a; Rauch et al., 2009; Wiklund, 1999) are mentioned as the potential causes of this inconsistency.

The problem of performance measurement was reviewed and discussed by researchers in the general field of business (e.g. Dess \& Robinson, 1984; Wall et al., 2004) start-up entrepreneurship (Sarkar, Echambadi, \& Harrison, 2001) and firm-level entrepreneurship (Rauch et al., 2009). All studies exhibited a strong correlation between perceived and archival indicators of performance and found no differences between them in regard to their association with other strategic dimensions of organizations. Rauch et al. (2009) in particular tested if there are any differences between perceived financial, perceived non-financial, and archival performance in studying the effect of EO on performance and concluded that there is no difference. To check if implementing the various indicators of performance may cause the inconsistency, the analytical techniques 
of crosstab and two-way chi square were used and no difference was found between studies, which applied perceived performance and others that used archived indicators of corporate $\left(\mathrm{X}^{2}(4, \mathrm{~N}=61)=2.352, \mathrm{P}=0.671\right)$ and international performance $\left(\mathrm{X}^{2}(4, \mathrm{~N}=\right.$ $51)=0.907, P=0.924)$. Thereby, performance measurement is not the reason for the uncertainty of the empirical findings.

The nonconformity of current studies about how to measure firm-level entrepreneurship can also lead to the inconsistency of findings. As was thoroughly discussed in the previous section of this chapter, many empirical studies have relied on orientation or EO as the proxy of firm-level entrepreneurship, while there is another stream of research that criticizes EO as a proper construct and suggests behavioral or combined measurements. This problem becomes worse in the internationalization context, where firm-level entrepreneurship can be also treated as a general or distinct international construct (Boso, 2010; Covin \& Miller, 2013). The chi square results $\left(\mathrm{X}^{2}(4, \mathrm{~N}=61)=\right.$ $7.998, \mathrm{P}=0.092$ ) demonstrated that the different proxies of firm-level entrepreneurship based on orientation, behavior or a mixture of both - may cause a partial disagreement among empirical studies. Actually, behavior-based and combined measurements (e.g. CE and intrapreneurship) display a higher probability of having a direct positive relationship than orientation-based measurements (e.g. EO and strategic posture). Consequently, choosing a construct that truly reflects the entrepreneurial activities of an organization seems influential in the body of research. The measurement appropriateness of firm-level entrepreneurship was previously discussed in detail and a mixed conceptualization was applied. This combined measurement reflects the entrepreneurship status of a company more accurately. Hence, this cannot be a big challenge for the validity and reliability of this research.

Although the majority of international entrepreneurship research consists of studies that investigate the effect of the general construct of firm-level entrepreneurship on international variables, there are others that modify and adjust the construct to an international context. These studies explicitly point out "this foreign country" or "in the marketplace of this foreign country" (Dimitratos, Voudouris, Plakoyiannaki, \& Nakos, 2012), "export markets” (Boso et al., 2012a; Ibeh, 2003), "international operations" (Zahra 
\& Garvis, 2000), and the other words or expressions that refer to internationalization (Knight \& Cavusgil, 2004; Kuivalainen et al., 2007; Sundqvist et al., 2012; Zhang et al., 2012; Zhou, 2007) in their questionnaires. Firm-level entrepreneurship in these types of studies benefits from the phenomenon of "concept traveling" (George \& Marino, 2011) and is treated as a distinct international construct. With respect to the research design, neither body of research is superior to the other, but understanding their inherent differences is important to avoid drawing inappropriate comparisons and generalizations (Covin \& Miller, 2013). Among all internationalization studies that were reviewed, just 19 papers (about 32.2\%) treated firm-level entrepreneurship as a distinct international measurement, while all other quantitative studies (40 articles, about 67.8\%) addressed it as a general construct. Although a larger number of papers applied a general measurement of entrepreneurship, measuring firm-level entrepreneurship in either way does not affect the final results (a two-way chi square test revealed no difference; $X^{2}(2, N=62)=0.896$, $\mathrm{P}=0.639$ ). Consequently, drawing aggregate conclusions based on a bundle of studies that are designed on different treatments of firm-level entrepreneurship (general vs. distinct international construct) is acceptable and does not harm the research credibility.

In their influential paper, Lumpkin and Dess (1996a) discussed a conceptual model of the relationship of firm-level entrepreneurship and performance. They suggested environmental factors and organizational characteristics as influential variables that may strengthen or weaken the relationship. Environmental variables as factors that may influence how EO is configured to reach superior performance have been gaining considerable attention (Guth \& Ginsberg, 1990; Wiklund \& Shepherd, 2005). In fact, the major part of firm-level entrepreneurship studies have focused on the outcome rather than the process, and context plays an important role in the expectations of the outcomes (Dess et al., 2011). The role played by environmental factors recalls the contingency analysis of organizational features and functions. Companies that align their strategies with the environment may act more successfully (Venkatraman \& Prescott, 1990). Alignment or fit refers to the way that variables such as environment and strategy pair together to improve performance (Lamont, Marlin, \& Hoffman, 1993). Fitting strategies with the 
environment and choosing a specific industry to maximize the strategic competencies are two common types of alignment (Venkatraman, 1989a).

Khandwalla (1972) was the first researcher who applied contingency analysis in the entrepreneurship literature. He believed that corporate performance should not be measured on the basis of organizational attributes, but instead it should come as the result of the fit between those attributes and particular dimensions of external environment such as environmental hostility and uncertainty. This approach was employed in the firm-level entrepreneurship studies from the beginning (e.g. Miller, 1988; Miller \& Friesen, 1983), and it is counted as an explanation for the inconsistency of empirical findings (Boso et al., 2013; Rauch et al., 2009; Wales et al., 2011). Including environmental factors in the analysis is also in consort with the contingency approach of internationalization, developed by Cavusgil and Zou (1994) and Yeoh and Jeong (1995) and employed by IE researchers (e.g. Oviatt \& Mcdougall, 1994). The contingency approach of international entrepreneurship supposes that firm-level entrepreneurship in specific environments in which the conditional factors are in line with entrepreneurial strategies could improve the international performance. This situational nature of the internationalization process has been considered in some models of internationalization such as the Uppsala model (Johanson \& Vahlne, 1977), but it is mainly ignored by a major body of international performance research, which has resulted in inconsistent findings across the literature (Francis \& Collins-Dodd, 2000).

The external environment has been conceptualized based on different factors such as hostility, heterogeneity, and dynamism (Miller, 1983; Miller \& Friesen, 1982; Yeoh \& Jeong, 1995); turbulence (Khandwalla, 1977; Naman \& Slevin, 1993); and volatility (Robertson \& Chetty, 2000). Hostility and dynamism are commonly used as influential moderators in firm-level entrepreneurship studies (Rauch et al., 2009); hence, they are applied to investigate the effect of the environment on the relationship of firm-level entrepreneurship and internationalization in this study. In hostile or dynamic environments, SMEs face two options to enhance their performance: changing the market where they compete or changing their strategy of competition (Zahra et al., 1997). Both changing the market (new entry) or choosing a more proactive strategy can be seen as 
forms of firm-level entrepreneurship (Lumpkin \& Dess, 1996a, 2001). Therefore, firmlevel entrepreneurship helps companies to successfully compete in hostile and dynamic environments. This conclusion is supported by Yeoh and Jeong's (1995) model of contingency analysis. Their model explains that entrepreneurial and conservative firms have their own unique characteristics which enable them to compete better under proper environmental situations. Figure 2-3 displays a schematic picture of their model.

\begin{tabular}{|c|c|c|}
\cline { 2 - 3 } Entrepreneurial Firms & Fit & Misfit \\
\cline { 2 - 3 } Conservative Firms & Misfit & Fit \\
\cline { 2 - 3 } & $\begin{array}{c}\text { Hostile } \\
\text { Environment }\end{array}$ & $\begin{array}{c}\text { Benign } \\
\text { Environment }\end{array}$
\end{tabular}

Figure 2-3: The conditional effect of entrepreneurship

A dynamic environment refers to a continuously changing environment (Zahra et al., 1997) in which current competition is volatile and becomes more and more innovative, while a static environment tends to maintain the current basis of the competition (Zahra, 1991). Dynamism is mainly related to the presence and stability of change, not to the rate of change per se (Miller \& Friesen, 1982). It creates opportunities, pushes companies to renew their structures through innovation, and increases their emphasis on venturing (Zahra, 1993b). Short life cycle products, highly innovative industries, fluctuating customer taste, unpredictable competitor actions and technological changes are the most common features of dynamic environments (Caruana et al., 2002). While dynamism displays the favorable facet of external environment due to creating opportunities and encouraging companies to be on the edge of technological change, hostility, in contrast, shows the unfavorable component (Zahra, 1993b) and threatens the mission and survival of companies (Antoncic \& Hisrich, 2001; Caruana et al., 2002; Zahra, 1991). Unstable industry setting, low margin, intense competition, harsh business atmosphere, scarcity of 
resources, limited growth opportunities, severe regulatory restrictions, shortages of labor or raw materials, unfavorable demographic trends, stress, risk and the lack of opportunities are the most recognizable characteristics of this kind of environment (Caruana et al., 2002; Khandwalla, 1972; Miller \& Friesen, 1983; Zahra, 1993b; Zahra \& Bogner, 2000; Zahra $\&$ Garvis, 2000). Dynamism pulls companies to have entrepreneurial activities through providing more opportunities, while hostility pushes them to pursue innovation as a source of competitive advantage (Kearney et al., 2013). In summary, dynamism and hostility refer to the different dimensions of environment, which respectively represent favorable and unfavorable situations and make entrepreneurial behavioral necessary but on the basis of different motivations.

A quick glance at Table 2-1 confirms the moderating effect of environmental factors on the relationship of firm-level entrepreneurship and performance, and firm-level entrepreneurship and internationalization. 11 out of 17 empirical papers of corporate performance in which the moderating effect of environment has been studied, reveal a significant positive interaction effect. Only six papers do not find a significant effect, which three of them propose the configurational approach as a more suitable way to study firm-level entrepreneurship. The number of internationalization studies that have investigated the interaction effect of environment and firm-level entrepreneurship is fewer, but they show a more reliable results. Only 10 papers of all reviewed internationalization papers have studied the effect of environment, and almost all of them confirm a significant interaction effect (only one paper demonstrates a partial significant effect). In attention to all the empirical studies and the theoretical explanation of contingency analysis, which assumes a conditional relationship between firm-level entrepreneurship and internationalization, it can be concluded that;

Hypothesis 5A: Among all types of companies, actual entrepreneurial firms are expected to show the highest level of international involvement in dynamic environments.

Hypothesis 5B: Among all types of companies, actual entrepreneurial firms are expected to show the highest level of international involvement in hostile environments. 
Hypothesis 6A: Among all types of companies, actual entrepreneurial firms are expected to show the highest level of international scale in dynamic environments.

Hypothesis 6B: Among all types of companies, actual entrepreneurial firms are expected to show the highest level of international scale in hostile environments.

Hypothesis 7A: Among all types of companies, actual entrepreneurial firms are expected to show the highest level of international scope in dynamic environments.

Hypothesis 7B: Among all types of companies, actual entrepreneurial firms are expected to show the highest level of international scope in hostile environments.

Hypothesis 8A: Among all types of companies, actual entrepreneurial firms are expected to show the highest level of the speed of internationalization in dynamic environments.

Hypothesis 8B: Among all types of companies, actual entrepreneurial firms are expected to show the highest level of the speed of internationalization in hostile environments.

\subsection{Networks and Internationalization}

Performing a contingency analysis may lead to a better delineation of how firm-level entrepreneurship influences corporate or international performance, but a more accurate explanation could be inferred from configurational analysis that contains more than one conditional factor (Dess et al., 1997; Wiklund \& Shepherd, 2005). Researchers have discussed why firm-level entrepreneurship in and of itself is not enough to improve corporate performance (Walter et al., 2006), and needs resources to successfully translate to superior performance. This is where SMEs often fail (Hitt et al., 2001; Stam \& Elfring, 2008). Actually, in a proper environment and with access to necessary resources, companies can convert their firm-level entrepreneurship to performance superiority (Wiklund \& Shepherd, 2005). In short, being and acting entrepreneurially commits a large amount of resources (Su et al., 2011; Tang et al., 2008; Zahra, 1991) that most SMEs fail to satisfy because of their size-related limitations (Freeman, Carroll, \& Hannan, 1983). Therefore, questions such as how SMEs should leverage their firm-level entrepreneurship 
to improve their international performance (Wales et al., 2013) and how its benefits could be sustained (Wiklund, 1999) are of tremendous value.

Maybe a network of international and local actors who assist SMEs to overcome their limitations is the best answer (Aldrich \& Zimmer, 1986; Ellis \& Pecotich, 2001; Peng \& Luo, 2000; Rialp \& Rialp, 2001; Wales et al., 2013; Zhou et al., 2009). International actors possess valuable knowledge about their home countries that is invaluable for successful internationalization (Sharma \& Blomstermo, 2003; Yli-Renko, Autio, \& Tontti, 2002). This knowledge helps SMEs to identify international opportunities (Chetty \& Stangl, 2010; Johanson \& Vahlne, 2006; Lee et al., 2001), reduce the cost and risk of their international activities (Zain \& Ng, 2006), and overcome their barriers to internationalization (Ghauri et al., 2003). Network ties also help companies to acquire resources that are necessary for the exploitation of opportunities (Elango \& Pattnaik, 2007; Yli-Renko et al., 2002; Zahra, 2005). Actually, the nature of networks, internationalization and firm-level entrepreneurship are interwoven, and understanding one without considering the other is not possible (Antoncic et al., 2004). Therefore, the simultaneous study of all is an important research issue (Walter et al., 2006) which has received much attention in both the entrepreneurship (Wales et al., 2011) and internationalization literature (Chandra et al., 2009; Coviello \& Munro, 1997; Nummela, 2004; Oviatt \& Mcdougall, 1994; Sharma \& Blomstermo, 2003; Zahra, 2005).

Briefly speaking, a company performing in a larger and more reliable network usually has a greater chance of successfully translating its entrepreneurial activities into international success (Harris \& Wheeler, 2005). Being a part of an international network reduces the cost of transaction, improves coordination with international partners, lowers the opportunistic behavior of partners (Park \& Luo, 2001), and helps companies to overcome "institutional voids" - situations where the government fails to correctly perform its job to create and strengthen institutions (Khanna \& Palepu, 2000). A network can affect SMEs' internationalization in two different ways. First, the knowledge that is provided by networks helps companies to identify international opportunities better than others who do not have access to that knowledge pool (Chandra et al., 2009; Ellis, 2011; Meyer \& Skak, 2002; Oviatt \& McDougall, 2005a). Second, it supports companies to 
expand trusting relationships with their customers, competitors and other business actors. Trusting relationship acts as a basis for resource sharing and assists SMEs to benefit from the synergistic effect of pooled resources (Chetty \& Blankenburg Holm, 2000a; Chetty \& Campbell-Hunt, 2004; Zahra, 2005). A shared pool of resources enables companies to exploit international opportunities more efficiently. Empirical studies also corroborate this explanation, showing how firms in both developed and developing countries rely on networks to explore and exploit international opportunities (e.g. Chandra et al., 2009; Musteen, Francis, \& Datta, 2010). However, the question raised that calls for further research (e.g. Ellis, 2011; Young et al., 2003) and which needs to be studied more is as follows: "How can a network help companies to identify and exploit international opportunities?" 


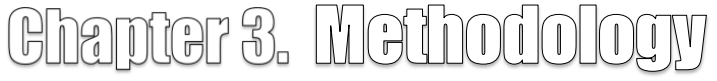

The cornerstone of a solid scientific study is the methodology that establishes a reliable roadmap or foundation to conduct the research in a proper way. Unfortunately, sometimes researchers confuse "methodology" with "methods", which may result in an incomprehensive research design that is unable to meet the purpose and goals of a study. This concern was explicitly stated by Waltz (1979, p. 13);

Have been much concerned with methods and little concerned with the logic of their use. This reverses the proper priority of concern, for once a methodology is adopted the choice of methods becomes merely a tactical matter. It makes no sense to start the journey that is to bring us to an understanding of a phenomenon without asking which methodological routes might possibly lead there.

To clarify the concepts, methodology is defined as;

The assumptions, postulates, rules, and methods - the blueprint or roadmap - that researchers employ to render their work open to analysis, critique, replication, repetition, and/or adaptation and to choose research methods" (Schensul, 2008a, p. 516).

And methods are described as;

The ways in which qualitative [and quantitative] researchers collect data to build their argument. Regardless of paradigmatic preference, all 
qualitative [and quantitative] research methods have common characteristics (Schensul, 2008b, p. 521).

Actually, methodology and methods point to the different dimensions of a research study; the former manifests the overall plan or logic of conducting a study, while the latter is a bundle of tools and techniques that focus on specific problems. Thus, they can be viewed as a toolbox and tools (Moses \& Knutsen, 2012). Methodology is a toolbox that contains methods as tools; to solve a particular research problem, the toolbox should encompass the appropriate tools.

Methodology is the main concern of this chapter, and methods are discussed as a sub-section.

\subsection{Research Philosophy}

People's beliefs and their way of looking at the world that determines the fundamental guidelines of gathering, analyzing, and applying data is called research philosophy. The most frequent philosophical views of business and political studies are positivism and constructivism; the former believes in a reality that can be understood to some extent, while the latter ascribes everything to the researcher and considers him/her as the constructor of a study.

From an ontological point of view, positivism believes in a reality, independent of the observer, which is uniform and orderly. Constructivism, on the other hand, questions this independent reality and highlights the role of the observer in performing a scientific study. All observational statements in the constructivist perspective contain bias and can be understood in different ways, while in the positivist view the science is created by careful neutral observations (Moses \& Knutsen, 2012).

Almost all studies have a degree of both perspectives, and there is no pure positivist or constructivist research. Moreover, in pragmatism, a more recent philosophical view, constructivism and positivism are considered as complementary perspectives. Pragmatism assumes the purpose of the study as the focal point and instructs researchers to apply both positivism and constructivism as far as they serve the purpose (Creswell, 2013). Understanding the internationalization of SMEs is regarded as the major purpose 
of this study and to serve that, the researcher does not hesitate employing positivist or constructivist viewpoints whenever they can help; therefore, it is more appropriate to call the philosophical view of this study the pragmatic philosophical perspective.

\subsection{Research Design}

Research design is an action plan which embodies the approach and strategies to perform a research study. In accordance with three different philosophical views, there are three main approaches to perform a research study: quantitative, qualitative, and mixed method (Creswell, 2013). Positivism dictates the quantitative approach, constructivism is in line with the qualitative approach, and pragmatism is a better fit with the mixed method approach; thus, the latter is better suited to execute this study. In addition, a mixed method design possesses better potential for more accurate and generalizable findings (Shah \& Corley, 2006; Slevin \& Terjesen, 2011) .

To execute the mixed-method approach, an explanatory sequential strategy is adopted "in which the researcher first conducts quantitative research, analyzes the results and then builds on the results to explain them in more detail with qualitative research" (Creswell, 2013, p. 15). From a theoretical point of view, it stands on the social science framework, which uses theory to cover different aspects of a research design;

A social science framework is placed at the beginning of studies, provides an explanation for the quantitative and (perhaps) qualitative components (e.g., data collection, analysis, interpretation) of a study, and informs the findings and results" (Creswell, 2013, p. 74).

Also, a sequential two-step literature review was performed to support the implementing strategy. The literature was primarily reviewed to develop the overall theoretical framework, hypotheses and supportive discussions, and it was again studied after obtaining the survey results in order to outline an analytical framework for analyzing the case. Practically, and in accordance with the explanatory sequential strategy, the research process followed two major steps. First, a large sample survey was carried out to investigate whether actual entrepreneurial companies are the most internationalized as the literature predicts. Since the results displayed a deviation from what was expected, a 
follow-up case study was carried out to describe the deviation and get a deeper understanding of SMEs' internationalization.

\subsection{Research Methods}

As mentioned earlier, this study draws on an explanatory sequential mixed method strategy, beginning with a survey and followed by case studies. Accordingly, dividing and discussing the research methods in two corresponding sections is helpful and easier to understand.

\subsubsection{Section One: Survey Study}

This part of the research follows the logic of quantitative methods to test the literaturedriven hypotheses. Research sampling and participants, variables, measurements, and analysis techniques are the most common parts of a quantitative research method that need to be discussed.

\subsubsection{Sampling and Participants}

This research has been performed among Iranian food and beverage SMEs. Iranian businesses are mostly neglected in the current literature and the number of studies that focus on their internationalization, especially from an entrepreneurship perspective, is very low. Actually, the major part of the literature has been focused on developed areas such as the United States (Dess et al., 2011) and European countries; thus, our understanding of the phenomenon is very limited in undeveloped or developing areas like Latin America, Sub-Saharan Africa, Eastern Europe, the Middle East and Southern Asia (Wales et al., 2011).

The Iranian definition of SMEs is very vague, and there are no solid predetermined indices to clearly separate SMEs from large companies (UNIDO, 2003). Although there is no official definition of SMEs, small companies are commonly defined as businesses with less than 50 employees. Because of the lack of an official definition, Iranian researchers usually borrowed the EU definition of SMEs (e.g. Ajdari, 2007; Ghanatabadi, 2005). The EU defined two indices to differentiate SMEs: the number of employees and the annual turnover. Obtaining the annual turnover of companies, especially in developing 
countries such as Iran, is nearly impossible. In the absence of turnover data, only the number of employees is used to identify SMEs (Ibeh \& Kasem, 2011). Accordingly, in this research the number of employees is used. Based on this index, all companies with fewer than 250 employees are defined as SMEs (Commission, 2003).

A usual source to identify target subjects is professional databases that are specifically designed to provide a list of companies based on specific filters. Several databases of this kind were used in previous studies to identify and select target companies, for example the TPO directory (Zanjani 2007), the KOMPASS7 business-to-business database (Ghanatabadi 2005), and so on. Despite the usefulness of these databases to provide an initial sample, especially for large companies, they do not deliver reliable data for smaller companies. Therefore, this research relies on governmental archives such as the archive of the Institute of Standards and Industrial Research of Iran (ISIRI) in Bushehr and Fars, the Bushehr Fisheries Organization, and Iran Small Industries, and the Industrial Park Organization (ISIPO) in Khorasan to primarily identify target subjects.

As recommended in the literature, the scope of the sample should be clear, its boundaries should be well-understood, and scholars must fight against a low response rate (Miller, 2011). To answer those recommendations and to avoid challenges and difficulties associated with mail or email surveys in countries like Iran, a face-to-face interview approach was applied. This method of survey is highly recommended because it generally results in a high response rate (Bryman, 2012), ensures that the respondent is a target subject (Miller, 2011), and permits researchers to resolve the interviewees' queries on the spot (Su et al., 2015), especially for translated questions in which items' wording are very similar to the original version and may not reflect the real meaning of the construct (George, 2011). This method is very common for a research context in which gathering primary data through mail or email is challenging and difficult (e.g Peng \& Luo, 2000; Su et al., 2015; Zhou et al., 2009).

A group of interviewers were trained and instructed to carry out the survey through a face-to-face interview in the Fars and Khorasan provinces. All interviews in Bushehr province were carried out by the researcher and his local assistance. Actually, cooperating with local interviewers can lead to better access to companies and procures more valid and 101 
reliable information (Zhou, Wu, \& Luo, 2007). Most companies were contacted by phone or visited personally after their union or institutional meetings. The study, its purpose, procedure, benefits, and who was responsible for what were briefly explained, and the respondents were ensured about the confidentiality of their information. Then, a meeting was scheduled for any company that agreed to participate. Among the 324 companies contacted, 216 agreed to participate, and 198 usable questionnaires were collected for further analysis. Therefore, the response rate was about $61 \%$, which is slightly higher than similar studies in the literature (e.g. Chen \& Hsu, 2013; Hagen et al., 2012; Knight \& Cavusgil, 2004).

The non-response rate of this study was also 39\%, which provides fairly good protection against non-response bias. Despite this, the extrapolation method of nonresponse bias (Armstrong \& Overton, 1977) on demographic characteristics of early and late respondents was also implemented to ensure more security. This method is based on the simple rule that "persons responding later are assumed to be more similar to nonrespondents" (Armstrong \& Overton, 1977, p. 397) and is frequently used in entrepreneurship and international business studies (e.g. Boso et al., 2013; Chen \& Hsu, 2013; Knight \& Cavusgil, 2004; Lisboa et al., 2011; Ripolles et al., 2010; Su et al., 2015). Comparing earlier and later respondents based on age and size reveals no significant differences $(\mathrm{P}<.05)$, indicating that non-response bias is not a major concern.

Most firm-level entrepreneurship studies accept the CEO as the main SME actor who truly reflects the company (Covin \& Slevin 1989); thus, interviewing CEOs as the overall representative of SMEs is an accepted approach (Rauch et al. 2009). The literature is full of studies that have used this method (e.g. Covin \& Slevin, 1989; Jantunen et al., 2005; Rauch et al., 2009; Wiklund \& Shepherd, 2003). The logic behind that is the traditional notion that the values and managerial philosophy of senior managers determine the strategic decisions of a small firm (Robertson \& Chetty, 2000). Typically, CEOs are the most informed regarding business strategies and the overall business situation (Heavey \& Simsek, 2013; Kreiser et al., 2012; Lyon et al., 2000; Zahra, 1996b; Zahra \& Covin, 1995; Zahra, Neubaum, et al., 2000), especially in SMEs, as they are at the core of decision-making processes and their orientation is equivalent to the orientation of their 
companies (Dai et al., 2014; Lumpkin \& Dess, 1996a; Zhang et al., 2012). Indeed, entrepreneurship in SMEs completely depends on top managers who "must work to create organizational architectures in which entrepreneurial initiatives flourish" (Ireland et al., 2009, p. 30); therefore, the construct of firm-level entrepreneurship that is operationalized from the CEOs' perspective captures a more holistic view of firms' operations (William J Wales, Patel, Parida, \& Kreiser, 2013).

Despite all the aforementioned benefits of relying on CEOs as the source of data, researchers should be cautioned about the common method bias that it may cause (Podsakoff \& Organ, 1986). This should especially be taken in consideration when all data representing both dependent and independent variables are gathered from the same people (Chang, van Witteloostuijn, \& Eden, 2010; Podsakoff, MacKenzie, Jeong-Yeon, \& Podsakoff, 2003). Common method bias refers to the "variance that is attributable to the measurement method rather than to the constructs the measures represent" (Podsakoff et al., 2003, p. 879). A number of remedies are proposed for this kind of bias including gathering data from different sources, professional guidelines to develop a questionnaire, designing a complicated study that contains interactions and is difficult to be visualized by respondents, and a number of statistical techniques such as the correlational marker technique, Harman's one-factor approach, the single common method factor, the multiple common method factor, and the partial correlation procedure (Chang et al., 2010; Podsakoff et al., 2003).

To guard against common method bias, both remedies of complicated research design and the statistical procedure of Harman's one-factor approach are used. Harman's one-factor approach applies an explanatory factor analysis procedure to check whether a single factor exists, which accounts for the majority of the covariance between measurements (Chang et al., 2010). The results of the explanatory factor analysis of unrotated factor solutions demonstrated 5 factors with eigenvalues larger than 1 , in which the first factor just accounted for 31.1 of the variance. A confirmatory factor analysis with all items loading on a single latent factor also revealed a significantly poor fit model (CMIN/DF=6.338, CFI=0.518, RMSEA=0.165, and SRMR=0.1931). These statistical calculations, the complicity of the research design, and ensuring respondents remain 
anonymous, ensure that common method bias is not a serious challenge. These remedies have been commonly used in previous studies on entrepreneurship and internationalization (e.g. Anderson \& Eshima, 2013; Boso et al., 2012a; Chen \& Hsu, 2013; Dai et al., 2014; Kraus et al., 2011; Lisboa et al., 2011; Rigtering et al., 2013; Su et al., 2015; Zhou et al., 2009).

\subsubsection{Research Variables and Measurements}

The quantitative part of the research has focused on the relationship of firm-level entrepreneurship and the internationalization of SMEs. The environmental factors of dynamism and hostility are also included as moderators to provide a more detailed explanation. Consequently, three different kinds of variables are presented in the overall framework of the research, namely dependent, independent, and moderator variables. As it is very common in quantitative studies and to deliver a more reliable description, it is helpful to control a number of intervening factors, which are called control variables.

As the dependent variable of this study, internationalization is a complicated phenomenon and is difficult to correctly define and measure. As Sullivan $(1994,1996)$ suggested, there is no widely accepted measurement of internationalization. Although a number of studies have applied a single criterion such as foreign sales ratio or the number of international markets as a proxy of the phenomenon, such a simple criterion fails to capture a complex concept like internationalization (Sullivan, 1994; Welch \& Luostarinen, 1988). In simpler words, using a simple criterion to measure internationalization may misinterpret the construct and, accordingly, warp the validity of the results (Sullivan, 1994). Also, to get a better understanding of the internationalization process, a multidimensional construct of internationalization is required (Reid, 1981; Welch \& Luostarinen, 1988). Consequently, a three-dimensional operationalization of internationalization including of scale, scope, and speed, which draws a holistic picture of the international activities of SMEs, was implemented in this study.

International scale (sometimes called international intensity or international degree) and international scope are the common dimensions of international performance (Autio et al., 2000; Frishammar \& Andersson, 2008; Javalgi \& Todd, 2011; Ripolles et 
al., 2007; Robertson \& Chetty, 2000; Sullivan, 1994; Zahra \& George, 2002; Zahra et al., 1997; Zhang et al., 2012). In a review study of international performance, Walters and Samiee (1990) demonstrated that $68 \%$ of reviewed papers implemented international scale and $13 \%$ employed international scope to measure international performance. International scale refers to the percent of total sales from international markets, while scope hints at the number of international markets where a company is operating (Ripolles et al., 2010; Ripolles et al., 2007; Zahra et al., 1997). Another important dimension of internationalization, one which recently has attracted much attention, especially in the international entrepreneurship area, is the speed of internationalization. Like other dimensions, there is no consensus on its definition (Hurmerinta-Peltom $\ddot{\mathrm{k} k i,} 2003$ ) and it is always mixed with other factors (Acedo \& Jones, 2007). The speed of internationalization is typically measured in terms of the time (number of years) between a firm's initial inception and its first international activity (Musteen et al., 2010; Ripolles et al., 2007).

All dimensions of scale, scope, and speed are objective measurements that depict the involvement of a firm abroad (Dimitratos et al., 2004); thus, they can be measured in a perceived or archival manner. Considering that most companies do not provide their archival performance statistics (Kraus et al., 2011), the difficulty in accessing that kind of information in some contexts (Li et al., 2005; Peng \& Luo, 2000) like Iran, the high correlation that exists between perceived and archival objective data (Sarkar et al., 2001), and the little difference shown between them in terms of the conclusions (Rauch et al., 2009), this research employed perceived indicators of internationalization.

Looking at the independent variable, firm-level entrepreneurship as the process of exploration and exploitation (Shane \& Venkataraman, 2000) is measured based on firms' entrepreneurial orientation and behavior. The orientation refers to strategies, processes, and decision making styles, and the behavior is the outcome that could be seen as new entries (Lumpkin \& Dess, 1996a). The first shows the top managers' tendency to accept innovative ideas ahead of competitors by accepting a calculated level of risk (Covin $\&$ Slevin, 1991), while the second deals with entrepreneurial outcomes such as innovation activities (introducing and developing new products, new production process, or new 
organizational methods), venturing (expanding operations in new and/or existing markets), and strategic renewal (changing the scope of business and/or its competitive approaches) (Simsek et al., 2007; Zahra, 1991). Entrepreneurial orientation and behavior have been applied interchangeably in some studies, but they actually refer to the distinctive dimensions of firm-level entrepreneurship. To design a holistic picture of entrepreneurship in a given company, combining both dimensions is needed. In this research, entrepreneurial orientation and behavior are combined in a profile model of firm-level entrepreneurship resulting in four distinct categories: non-entrepreneurial, latententrepreneurial, forced entrepreneurial, and actual entrepreneurial.

Fortunately, there are validated measurements developed by former researchers for both EO and CE. EO has been measured in different ways in the literature (Morris, Webb, et al., 2011). While the original and also most popular measurement of EO (Rauch et al., 2009; Rosenbusch et al., 2011) - developed by Miller (1983) and Covin and Slevin (1989) - describes the construct as an aggregation of innovativeness, proactiveness, and risktaking, there are other measurements that use more (Lumpkin \& Dess, 1996a) or fewer dimensions. The original construct of Miller/Covin and Slevin is employed in this study because of its popularity (Anderson et al., 2014; Covin \& Miller, 2013; Rauch et al., 2009; Wiklund, 1999) and its robustness in international settings (Knight, 1997; Kreiser et al., 2002; Runyan et al., 2012). This measurement is called the "foundational scales" of EO by some researchers (e.g. Short et al., 2010).

Also, a previously validated measurement of $\mathrm{CE}$ is applied. In contrast to EO, the measurements of $\mathrm{CE}$ are less diversified and there is better agreement on its dimensions. It is usually presented as a three-dimensional construct of innovation, venturing, and strategic renewal (Heavey \& Simsek, 2013; Simsek \& Heavey, 2011; Simsek et al., 2007; Zahra, 1991, 1996a). Some studies have implemented a larger construct by adding a few dimensions of EO to the measurement (e.g. Garcia-Morales et al., 2014), but the threedimensional version is more common and is a better fit with the profile measurement model of firm-level entrepreneurship, which clearly separates EO and CE. In addition, one 
item of $\mathrm{CE}^{1}$ has been removed because of its obvious overlapping with internationalization.

There is a long-lasting argument regarding the conditional effect of firm-level entrepreneurship on performance. Firm-level entrepreneurship may show a different association with performance or internationalization, depending on the environmental conditions (Rauch et al., 2009). Conceptual and empirical studies of entrepreneurship revealed that the relationship between firm-level entrepreneurship and performance is not universal, and it could be moderated by the business environment in which companies are performing. Although the strategic management literature has counted and discussed several dimensions of business environments, the dimensions of environmental dynamism and hostility are salient in the entrepreneurship research (Miller \& Friesen, 1983; Zahra et al., 1997). These environmental factors have been developed (Khandwalla, 1977; Miller \& Friesen, 1982, 1983), validated (Covin \& Slevin, 1989; Naman \& Slevin, 1993) and commonly used (Anderson et al., 2014; Balabanis \& Katsikea, 2003; Becherer \& Maurer, 1997; Covin \& Slevin, 1989; Kraus et al., 2011; Kreiser et al., 2012; Lumpkin \& Dess, 2001; Wales et al., 2013; Wiklund, 1999; Wiklund \& Shepherd, 2005) in previous studies.

Environmental dynamism refers to the positive aspect of the environment that provides more and richer entrepreneurial opportunities, while hostility deals with the negative aspect that causes uncertainty and unfavorable conditions (Zahra, 1993a, 1993b). Environmental dynamism is operationalized as the sum of product obsolescence, the predictability of competitors' actions, the predictability of demand and consumer taste, the rate of technological change, and the rate of change in firms' marketing practices. Environmental hostility, on the other hand, is an aggregation of the environmental threat to firms' survival, competition on price and quality, dwindling markets, the scarce supply of labor and material, and government interference (Khandwalla, 1977; Miller \& Friesen, 1982).

In addition, a number of intervening factors were also controlled to remove their influence on the dependent variable. One of these factors that may influence the

${ }^{1}$ We have expanded our international operations significantly. 
international activities of SMEs is the structure of their industry (Johanson \& Vahlne, 1977; Kuivalainen et al., 2004; Oviatt \& Mcdougall, 1994; Ripolles et al., 2007). On some occasions, the characteristics of an industry are even more influential than nationality when it comes to studying international behavior (Boter \& Holmquist, 1996). To control the effect of industry structure and national culture, this study limits its scope to just one industry in one country: the food and beverage industry of Iran. Even though this may reduce the generalizability of the results, it is needed to achieve valid and reliable conclusions. Firm size (Balabanis \& Katsikea, 2003; Dhanaraj \& Beamish, 2003; Francis $\&$ Collins-Dodd, 2000) and previous international experience (Axelsson \& Agndal, 2000; Javalgi \& Todd, 2011; Kuivalainen et al., 2007; Lan \& Wu, 2010; Reuber \& Fischer, 1997) are also represented as factors that may influence the decision and subsequent activities of internationalization. Thus, they are usually controlled in internationalization research (e.g. Dai et al., 2014; Jantunen et al., 2005; Javalgi \& Todd, 2011; Yiu et al., 2007; Zhang et al., 2012; Zhou et al., 2009).

The history of a company can greatly influence its internationalization (Madsen \& Servais, 1997; Oviatt \& Mcdougall, 1994) because it helps to access international networks that facilitate the internationalization process (Zain \& Ng, 2006). Larger firms also have more resources available, which helps them to enjoy better maneuverability in international markets (Bloodgood, Sapienza, \& Almeida, 1996; Dunning, 1988; Zahra, Ireland, \& Hitt, 2000). As previously explained, the best proxy of firm size - especially for a country like Iran where accessing financial data is hard if not impossible - is the number of employees. This proxy is frequently used by other studies on internationalization and entrepreneurship (e.g. Balabanis \& Katsikea, 2003; Dhanaraj \& Beamish, 2003; Liu et al., 2011; Zhou, 2007). Previous international experience is commonly explained as the number of years that a firm's CEO has spent studying and working abroad (McDougall et al., 2003).

With attention to all the discussion on research variables and recommendations to apply already-developed and validated measurements instead of developing new ones (Wiklund, 1998), this study applies currently validated questions to perform the survey. Table 3-1 provides a summary of the measurements employed. All constructs of EO, CE, 
environmental dynamism, and environmental hostility were measured consistently, using a 7-point Likert scale. The 7-point Likert scale conveys interval properties, which allows the application of the solid techniques of data analysis, and has been successfully applied in similar studies (Robertson \& Chetty, 2000). It also minimizes the time needed to answer questions (Knight \& Cavusgil, 2004).

Table 3-1: Research variables and measurements

\begin{tabular}{|c|c|c|c|}
\hline Vari & bles & Operationalization & Examples of applications \\
\hline \multirow{3}{*}{ 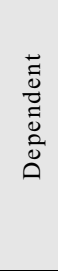 } & $\begin{array}{l}\text { Internationalization } \\
\text { scale }\end{array}$ & International sales ratio & \multirow[t]{2}{*}{$\begin{array}{l}\text { Autio et al. (2000), Frishammar } \\
\text { and Andersson }(2008) \text {, and Zahra } \\
\text { and George }(2002) \text {. }\end{array}$} \\
\hline & $\begin{array}{l}\text { Internationalization } \\
\text { scope }\end{array}$ & $\begin{array}{l}\text { The number of international } \\
\text { markets }\end{array}$ & \\
\hline & $\begin{array}{l}\text { Internationalization } \\
\text { speed }\end{array}$ & $\begin{array}{l}\text { Time elapsed between start-up } \\
\text { and first international sale }\end{array}$ & $\begin{array}{l}\text { Musteen et al. (2010), Reuber } \\
\text { and Fischer (1997), and Zahra, } \\
\text { Matherne, and Carleton (2003). }\end{array}$ \\
\hline \multirow{2}{*}{ 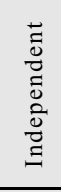 } & \multirow[t]{2}{*}{$\begin{array}{l}\text { Firm-level } \\
\text { entrepreneurship }\end{array}$} & Entrepreneurial orientation & $\begin{array}{l}\text { Covin and Slevin (1989), Covin } \\
\text { and Slevin (1991), Lumpkin and } \\
\text { Dess (1996b), and Wiklund and } \\
\text { Shepherd (2005). }\end{array}$ \\
\hline & & Corporate entrepreneurship & $\begin{array}{l}\text { Simsek et al. (2007), Heavey and } \\
\text { Simsek (2013), and Zahra (1991) }\end{array}$ \\
\hline \multirow{2}{*}{ 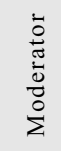 } & $\begin{array}{l}\text { Environmental } \\
\text { dynamism }\end{array}$ & $\begin{array}{l}\text { Positive aspect of } \\
\text { environment }\end{array}$ & \multirow{2}{*}{$\begin{array}{l}\text { Miller and Friesen (1983), Covin } \\
\text { and Slevin (1989), and Zahra } \\
(1996 b) \text {. }\end{array}$} \\
\hline & $\begin{array}{l}\text { Environmental } \\
\text { hostility }\end{array}$ & $\begin{array}{l}\text { Negative aspect of } \\
\text { environment }\end{array}$ & \\
\hline \multirow{2}{*}{$\begin{array}{l}\overline{0} \\
\stackrel{\Xi}{\Xi} \\
0 \\
0\end{array}$} & Firm size & Number of employees & $\begin{array}{l}\text { Balabanis and Katsikea (2003), } \\
\text { Dhanaraj and Beamish (2003) } \\
\text { and Bloodgood et al. (1996). }\end{array}$ \\
\hline & $\begin{array}{l}\text { CEO's Previous } \\
\text { International } \\
\text { Experience }\end{array}$ & $\begin{array}{l}\text { Number of years being or } \\
\text { studying abroad }\end{array}$ & $\begin{array}{l}\text { Axelsson and Agndal (2000), } \\
\text { Lan and Wu (2010), and } \\
\text { Dimitratos et al. (2004) }\end{array}$ \\
\hline
\end{tabular}

\subsubsection{Validity and Reliability}

To achieve reliable and scientific conclusions, employing valid and reliable measurements is necessary (Knight, 1997). A field of study could not be called science if it did not rely on reliable measurements (Peter, 1979). Accordingly, approving the validity and reliability of measurements is a necessary step in performing scientific research. Validity refers to the extent that a construct truly measures what it is supposed to measure (Peter, 1979). Although many studies discuss reliability as a separate concept than validity, 
reliability, in fact, is an aspect (Venkatraman \& Grant, 1986), or perhaps a necessary condition (Knight, 1997), of validity.

Reliability, sometimes called internal validity, is the degree to which a measurement is free from error (Peter, 1979). In other words, it explains the internal consistency and describes the accuracy of a measurement when applied in different contexts. There are different techniques to evaluate reliability, such as Cronbach's Alpha and the reliability coefficients of structural equation modeling (Venkatraman \& Grant, 1986). Cronbach's Alpha is the most popular method of reliability evaluation (Knight, 1997), but has been criticized for being a lower bound on true reliability (Peterson \& Kim, 2013). Consequently, the composite reliability of structural equation modeling has been suggested instead, as it delivers a better estimate of the true reliability (for more information, please see Peterson and Kim (2013)). Composite reliability using confirmatory factor analysis for all measurements is calculated and discussed in Chapter Four.

Besides internal validity, researchers have suggested content, convergent, and discriminant validities, which are necessary to check in order to obtain reliable results (Venkatraman \& Grant, 1986). A detailed argument of convergent and discriminant validities is presented in Chapter Four, and therefore only content validity is discussed here. As previously mentioned, validity deals with the extent to which a construct measures the concept that it is intended to. A very simple way of performing a validity check-up is to assess the consistency of experts' explanations about a given construct. If a considerable number of researchers in a field have frequently used a given measurement to gauge a particular concept, then it is concluded that the measurement is valid. This kind of validity, which relies on the expert's ideas and the consistent use of a measurement, is called content validity. All measurements in this study are previously-validated measurements, which are commonly applied in a similar and consistent structure in terms of their dimensions and individual items; thereby, all measurements meet the condition of content validity. 


\subsubsection{Quantitative Data Analysis}

Several data analysis techniques were employed in this research to check on biases, validity, reliability, and hypotheses testing. First, t-test, exploratory and confirmatory factor analysis were used to check the possibility of non-response and common method bias. Factor loadings and average extracted variance of confirmatory factor analysis were also employed to modify and ensure the composite reliability, convergent validity and discriminant validity of the measurements. Second, hierarchical regression, cross-tabs method, and log linear analysis were applied to test the research hypotheses. Hierarchical regression is an appropriate technique for evaluating contextual and configurational research models (Cohen, Cohen, West, \& Aiken, 2003), and is well established as a model estimator in entrepreneurship research (Rauch et al., 2009).

Since the independent variable of all the hypotheses was the profile model of firmlevel entrepreneurship, it had to be codified before entering the regression models. The contrast coding was selected to codify the independent variable because it has greater potential to deliver a richer post hoc analysis than a simple dummy coding scheme. With the hierarchical regression method, variables are entered sequentially; the main effects are added after control variables, followed by interactions. In this way, a researcher can check whether a higher order model accounts for a statistically significant improvement of explained variance (R-squared change) (Wiklund \& Shepherd, 2005). To test the hypotheses of international involvement in which both the predictor and outcome were nominal, crosstabs method and log linear analyses were used.

\subsubsection{Section Two: Case Studies}

The final results of the survey were not entirely in accordance with what the literature had predicted. While the literature had supported this idea that the actual entrepreneurial profile was the most internationalized type, the survey showed the force entrepreneurial companies as the most internationalized firms - except in hostile environments, in which the conclusions were in line with the literature. Thus, another question was raised: why does the forced entrepreneurial type reveal better internationalization, while the literature predicted the actual entrepreneurial companies as the most internationalized group? To 
answer this question, a case study was employed because, as Yin (2003) argues, it has great potential to answer both "how" and "why" questions.

To understand the causes of the unexpected results and to ask about the motivations of the forced entrepreneurial companies, a phone interview was conducted. More than 10 companies were contacted and briefly interviewed. Those interviews surfaced a new but important dimension of internationalization that was ignored in the survey. Almost all of the interviewed companies relied on business networks as their mechanism to sell abroad. They used some general expressions that implied to business networks such as "Company X helped us to find an international costumer", "we prefer and sometimes are forced to work together to produce a qualified product", and "if we act on our own, we cannot make things work". The literature of internationalization was reviewed again after having a primary investigation to recheck the role of business networks in the internationalization of SMEs. Fortunately, there is a large body of research on internationalization and business networks which furnishes an instructive view for studying the network structure, and helps the researcher to design an analytical framework for explaining how network structure affects the internationalization of entrepreneurial SMEs (for more detail, see Chapter Four, Section Two).

Both network structure and network evolution (the dynamics of a network over time) are considered important in network studies, but because of the time and cost limitations, the existence of more advanced analytical techniques, and the fine-grained theories of network structure, this study focuses on network structure and leaves the network evolution to future studies.

The case study is highly recommended for performing research in business and industrial networks because it pays deep attention to the embedded attribute of network relationships, and delivers a causal explanation of how actors' behavior is affected and how networks are created (Easton, 1998; Halinen \& Tomroos, 2005). As Wakkee (2007) claimed, about half of the empirical studies on internationalization and entrepreneurship employ the qualitative design of case studies, building upon interviews and secondary data (Andersson \& Wictor, 2003; Rialp, Rialp, \& Knight, 2005). This approach is also very common in the study of international entrepreneurship from a network perspective (e.g. 
Chetty \& Blankenburg Holm, 2000b; Chetty \& Stang1, 2010; Coviello \& Munro, 1995; Coviello \& Munro, 1997; Ibeh \& Kasem, 2011; Loane \& Bell, 2006; Sharma \& Blomstermo, 2003).

\subsubsection{Selection and Analysis of the Cases}

A growing body of knowledge exists about how to perform and analyze a qualitative study (e.g. Eisenhardt, 1989; Yin, 1994, 2003). To conduct case study research, two general strategies are available: single or multiple-case studies. A single-case study relies on one case, deeply explains its features and context, and provides a very detailed within-case analysis. A multiple-case study, in contrast, chooses several cases, sometimes includes opposite or contrast cases, and contains both within and cross-case analyses. The theorybuilding properties of multiple-case studies have been discussed in detail by Eisenhardt (1989), who mentioned there is no ideal number of cases but suggested to select between four and ten. To perform the qualitative step of this research, five cases were selected: a forced entrepreneurial (international), two actual entrepreneurial (an international and a domestic), a latent entrepreneurial (domestic), and a non-entrepreneurial (domestic) company. These firms were chosen because, as Eisenhardt (1989) recommended, they cover the different profiles of firm-level entrepreneurship and internationalization, which enable the researcher to achieve reliable within and cross-case analyses. This research, actually contains a case from each category and also an additional contrast case from actual entrepreneurial classification, which is the target type of the analysis.

A two-step process was followed for the selection of the cases. First, ten companies from each category were selected and invited to a deep, detailed interview. Second, five cases were chosen based on their agreement to be interviewed, researcher access, and other important characteristics such as their internationalization or performance. The nonentrepreneurial and latent-entrepreneurial companies were domestic, and there was no access to counter-cases because of their limited number, their refusal to attend more detailed interviews, and the researcher's constraints such as cost, time or an informal relationship, which is very beneficial in conducting a cases study research. In the same vein, just an international forced entrepreneurial firm was available, and for the actual entrepreneurial profile only, both international and domestic types were interviewed. 
Regarding the research hypotheses that counted the actual entrepreneurial type as the target category, and the result of the survey which demonstrated forced entrepreneurial companies as the highest international group, the selected cases are powerful enough to render a deep and inclusive analysis. To respect anonymity, individual companies were given codes: Non-Entre for the domestic non-entrepreneurial, Latent-Entre for the domestic latent entrepreneurial, Forced-Entre for the international forced entrepreneurial, Actual-Entre for the domestic actual entrepreneurial, and Counter-Case for the international actual entrepreneurial. It is worth noting that the selection of cases follows a replication logic (Yin, 2003), sometimes called theoretical sampling (Eisenhardt, 1989), in which the number and heterogeneity of cases secures an proper balance of saturation to answer a target question. Therefore, the selected cases may not be a true representative of the underlying population.

Before an interview, press and an internet search was performed to collect primary information about the cases and their contexts. Informal information was also received from officials and regular employees, both before and after the interviews, which helped to ensure the researcher about the accuracy of the data from the interviews. The primary and informal information helps researchers to conduct a more active interview and to write a better description about the selected cases. All interviews were performed by the researcher at the companies' formal office. Each interview began with general questions about the company and the process that the entrepreneur had followed to start it up. During this step, which mainly focused on getting a general picture of the company, the main questions were usually followed by several improvised inquiries, which helped the researcher to gain a clearer image of the company, the CEO, and the firm's entrepreneurial and internationalization status. In the next step, which was more structured and where questions followed a certain process, the network activities of the companies were discussed. First, a number of open-ended questions were asked to prepare the CEOs' minds and give them some ideas about their business networks. Those questions were placed under the label "network picture", and CEOs were asked to talk about entities around themselves such as people, companies, and groups of companies that may affect their businesses. Then, they were instructed to (1) draw a schematic picture of their 
business network on the paper, (2) identify other companies that may have been ignored in their drawing by asking about indirect relationships, and (3) discuss their ideas about their position in the networks, the ideal position that they want to achieve, and the challenges that were faced in their networking activities. After reviewing the "network picture" questions that helped CEOs to clear their minds about the networks and entities around them, a network matrix - a matrix that describes actors and their relationship status - was issued and filled out. All the information collected from both the network pictures and network matrices was used to describe the cases and design their network maps.

An explanation-building, pattern-matching technique was used to analyze the cases (Eisenhardt, 1989; Yin, 2003). To do so, an analytical framework that incorporates the international entrepreneurship process and network structure was developed (see Figures 4-6). Then, a detailed explanation of each case was presented; first, the general characteristics of each company were described, and then they were analyzed based on what the analytical framework proposed. Finally, a cross-case explanation was yielded by first comparing all the cases, and then comparing the Actual-Entre and Counter-Case. Almost all within-case analyses were performed using qualitative data, but to execute the cross-case analysis, a deep quantitative social network analysis was employed. The unit of analysis of the cross-case analysis was the overall network structure designed through information provided by the CEOs. CEOs are usually regarded as the primary informants who possess the direct and first-hand experience and knowledge of a company's involvement in network relationships; thereby, they are appropriate to be interviewed in network case studies (Coviello, 2006).

\subsubsection{Case Study Trustworthiness}

The validity and reliability of survey instruments guarantee reliable conclusions; this issue is discussed as trustworthiness in the qualitative research. It is a criterion to secure the quality of research results (Yin, 1994), but at the same time can also be considered a research goal (Guba \& Lincoln, 1989). To ensure trustworthiness, a number of strategies were developed called verification strategies. These strategies instruct a researcher to follow a procedure to increase the validity and reliability of their qualitative research such as methodological coherence, sample appropriateness, concurrent collection and analysis 
of data, and theoretical thinking (Morse, Barrett, Mayan, Olson, \& Spiers, 2008). Data coherence refers to the congruence of a research question and the method that is used to answer that question. The case study approach is applied to answer why forced entrepreneurial companies show a higher degree of internationalization, while actual entrepreneurial firms are expected to. This is a "why-type" question, and as previously stated, the case study is an appropriate approach to answer that. Furthermore, a descriptive write-up method, accompanied by a literature-driven analytical framework which relied on social network analysis, formed a matching analysis procedure.

The appropriateness of the selected cases was discussed in the previous section. The cases were selected in a way that covers all classifications of the profile model, and it also included of an extra counter-case of actual entrepreneurial type that provided more heterogeneous data on the internationalization of that type. All in all, the case selection procedure ensured dissimilar and adequate data for achieving valid and reliable conclusions. Perhaps the boldest verification strategy in this research, and one that is highly respected, is theoretical thinking. The four-fold model that acted as a basis for case selection was designed based on a comprehensive literature review. More importantly, the analytical framework of the case analysis is deeply rooted in international entrepreneurship and network theories that guarantee thinking theoretically throughout the research. Applying all verification strategies together secures the validity and reliability of the research (Morse et al., 2008).

The verification strategies are very useful for obtaining valid results, but they do not ensure the reliability of qualitative research. This means respecting verification strategies does not improve the generalizability of findings. Several remedies were suggested to solve the problem of poor reliability. Merriam (1995), for example, proposed thick description, multi-site design, model comparison, and sampling within as strategies which may help to improve the reliability of qualitative research. Thick description means explaining cases, their characteristics, situation and contexts in a precise and detailed way. Therefore, other researchers who want to apply final conclusions can compare their cases, identify their similarities and differences, and apply the results with more caution. Case description as a part of within-case analysis serves this task well in this study, and assists 
other researchers to check the similarities and differences of cases, their characteristics, and contexts. The results of within and cross-case analyses are also compared with similar empirical studies to establish supportive literature, or if any conflicts exist between the research conclusions and other empirical studies in the literature, describe the reasons behind them. Also, whenever and wherever was possible, more than one person was met to gather additional data. However, as mentioned several times, the formal target participant of both the survey and case study were the companies' CEOs, and if any extra data was gathered, it happened in the presence of the CEOs.

Finally, it is worth mentioning that using both single and aggregate analysis as applied in this study may strengthen the robustness of the analysis (Freeman, Edwards, \& Schroder, 2006). Also, a number of precautions suggested by Huber and Power (1985) were implemented that could help to improve the trustworthiness, for example the primary information seeking from the internet and press, as previously described. 


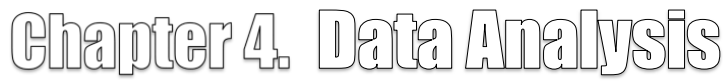

In accordance with the research process, data analysis is also discussed in two separate sections. The survey section contains validity and reliability techniques to check the credibility of the instruments and statistical analysis to test the hypotheses. In the final part of the survey section, hypotheses are summarized in a way that shows a quick and clear image of the results. The qualitative section describes all the cases minutely and proposes a cross-case analysis to highlight the differences. IBMSPSS 22 and its Structural Equation Modeling (SEM) add-on (AMOS) are used for statistical work, and UCINET 6 is employed for network analysis. NetDraw 2.155 is also applied to visualize the network structure of the cases.

\subsection{The Statistical Analysis of the Survey Data}

Confirmatory Factor Analysis (CFA) is an advanced technique frequently applied in recent studies to inspect the validity and reliability of research instruments. To have a more accurate assessment of the research credibility and benefit from more advanced techniques, CFA is used to appraise the validity and reliability. Also for testing the hypotheses, a hierarchical regression of contrast coding is applied that yields a dynamic image of post hoc analysis. 


\subsubsection{Confirmatory Factor Analysis}

As briefly mentioned before, a confirmatory factor analysis based on the maximum likelihood approach was executed to draw a complete picture of the measurement structures, as well as their reliability and validity. All independent and moderator variables were added to the CFA model to examine the internal convergence and the external discrepancy of the constructs. Because the internal convergence and external discrepancy of the full constructs of EO and CE are at the center of attention, and to be in line with the conceptualizations of those constructs as the second-order reflective measurements, the convergence and discriminant validities of EO and $\mathrm{CE}$ are inspected and discussed at their second level (a schematic model of the CFA model including all standard loading factors can be found in the appendix).

Chi-square is traditionally applied to evaluate the fit of CFA and SEM models; a significant chi-square value depicts a substantial difference between a latent model and observed sample covariance and is a signal to reject the model (Bagozzi \& Youjae, 1988). Because running a SEM or a CFA model usually requires a large sample size, and since the chi-square significance test is very sensitive to the sample size (it signifies a very small deviation in a big sample), researchers are advised to rely on other indices of goodnessof-fit to evaluate latent models (Anderson \& Gerbing, 1988; Bagozzi \& Youjae, 1988; Fornell \& Larcker, 1981). Comparative Fit Index (CFI) is adjusted for the degree of freedom and ranges in value from 0 to 1.00 (Byrne \& Gavin, 1996; Byrne \& Shavelson, 1996). It is calculated through comparing restricted and null models, and the values of .95 (Hu \& Bentler, 1998) or .9 (Byrne \& Gavin, 1996; Byrne \& Shavelson, 1996) are suggested as acceptable lower-limit cutoffs of the index. Root Mean Squared Error of Approximation (RMSEA) is another popular goodness-of fit index, which is commonly use in CFA models. RMSEA values in the range of .05 to .08 show fair fit, and that values bigger than .10 signify poor fit (Browne \& Cudeck, 1989). Standardized Root Mean Square Residual (SRMR) is a rank order index that shows the fit of different nested models by calculating residuals. The smaller value of the index displaying a better fit of a model (Bagozzi \& Youjae, 1988). Values lower than .08 indicate good fit and that values between .08 and 1.00 show fair fit (Yang, Arens, \& Watkins, 2014). 
The first step of CFA is to find a model that is adequately matched with sample data. Without having a fitted CFA model, discussing subsequent analyses such as validity and reliability is misleading. All indicators were entered and the goodness-of-fit indices of the model were checked $(\mathrm{CMIN} / \mathrm{DF}=2.708, \mathrm{CFI}=.817, \mathrm{RMSEA}=0.093$, and SRMR=0.1070). It is very common that CFA models are not adequately fitted in this step, and researchers are advised to modify models based on goodness-of-fit indices and theoretical justification (Byrne, 2013). This instruction was followed and a number of modifications were applied. As was recommended, the goodness-of-fit indices were applied as the criteria of modification whenever they were defensible from a theoretical point of view. In other words, based on Lagrange multiplier values calculated by AMOS, the unfit indicators were identified, correlated or removed if their alteration could be justified from a theoretical perspective and the empirical context of the research. The first legitimate type of modification is called correlated error (Byrne \& Shavelson, 1996). Correlated error means allowing the measurement errors of the indicators of a latent factor to freely covariate with each other. Actually, it shows that the measurement error of the indicators of a latent factor do not follow a perfect random pattern. It mainly happens because of redundancy of item contents, response pattern bias, or having yes-no questions (Byrne \& Shavelson, 1996). In this research, the common method bias was checked and it was not found to be a serious challenge. Also, all questions were designed using a sevenpoint Likert continuum. Therefore, the only reason for the correlated error was the redundancy of item contents. This means the error-correlated indicators in this research indicate the questions, which target the same contents.

The primary analysis of modification indices revealed a correlated error between $\mathrm{EOI} 2^{1}$ and $\mathrm{EOI} 3^{2}$ (correlating their errors improved the chi-square value of 66.45 ). Further analysis displayed this type of error correlation between $\mathrm{EH} 2^{3}$ and $\mathrm{EH} 3^{4}$ (correlating their

\footnotetext{
${ }^{1}$ We have introduced many new lines of products and services.

2 Our changes in products and service lines are quite dramatic.

3 Our organization has tough price competition.

4 We have severe competition on product quality or novelty.
} 
errors improved the chi-square value of 46.13), $\mathrm{CESR}^{1}{ }^{1}$ and $\mathrm{CESR} 5^{2}$ (correlating their errors improved the chi-square value of 30.14 ), CESR $1^{3}$ and $\mathrm{CESR} 2^{4}$ (correlating their errors improved the chi-square value of 17.17), $\mathrm{CEV}^{5}$ and $\mathrm{CEV}^{6}{ }^{6}$ (correlating their errors improved the chi-square value of 11.51), $\mathrm{EH} 3$ and $\mathrm{EH} 5^{7}$ (correlating their errors improved the chi-square value of 10.25), and $\mathrm{CEV} 3^{8}$ and CEV6 (correlating their errors improved the chi-square value of 10.073). After freeing all theoretically justifiable correlated errors, the goodness-of-fit indices increased substantially (CMIN/DF=2.312, CFI=0.861, RMSEA=0.082, and SRMR=0.1028), but they did not reach the adequate thresholds.

The next step of model fitting is to look at factor loadings and remove items which show the lowest values of factor loading. The CFA model should entirely run again after removing each indicator, and the goodness-of-fit indices and the possibility of drawing new justifiable correlated errors should be rechecked. Following this approach, the model was rerun five times and in each run, one item was removed to reach the adequate fit $(\mathrm{CMIN} / \mathrm{DF}=2.155, \mathrm{CFI}=0.90, \mathrm{RMSEA}=0.077$, and $\mathrm{SRMR}=0.0842)$. The EH2 (with the loading factor of 0.19), EOI3 (with the loading factor of 0.44 ), $\mathrm{EH}^{9}$ (with the loading factor of 0.47), EH3 (with the loading factor of 0.45), and CEV6 (with the loading factor of 0.56) were removed. All remaining factors in the model showed factor loadings higher than the 0.4 recommended by Ford, Maccallum, and Tait (1986). Removing EOI3 and CEV6 does not harm the overall factors of innovativeness and corporate venturing because they had indicated a high redundancy in their contents with other items (please look at their correlated errors). In the case of environmental hostility, however, the errors of the indicators were not correlated, but removing those items could be explained by

\footnotetext{
1 We have reorganized operations to ensure increased coordination and communication among units.

2 Our organization has renewed the portfolio of activities within units.

3 We have divested several unprofitable units.

4 Our organization has changed its strategy for each unit.

5 Our organization has entered many new industries.

6 We have focused on improving the performance of our current business rather than entering new industries.

7 We have a scarce supply of labor/material.

8 We have acquired many companies in very different industries.

9 Government interference is a severe challenge in our industry.
} 
considering the fact that the investigated companies were more dependent on cooperation than competition in their daily business activities.

The convergent and discriminant validities, as well as the composite reliability of the constructs, were calculated using the fitted CFA model. The convergent validity was double-checked by applying two different but popular analytical methods. First, as suggested by Anderson and Gerbing (1988), all factor loadings were inspected to see if they were significant or not. Fortunately, all factor loadings were significant at 0.001 of alpha level. Next, the recommended procedure of Fornell and Larcker (1981), which discusses convergent validity in terms of Average Variance Extracted (AVE), was used to reconfirm the results of the earlier method. Unfortunately, the construct of EH did not pass the critical threshold of this approach (its AVE was lower than 0.5).

The discriminant validity was also double-checked implementing the constrainedunconstrained models approach (proposed by Anderson and Gerbing (1988)) and the AVE comparison method (suggested by Fornell and Larcker (1981)). The first approach examines if the difference between constrained (covariance between two factors is equal to one) and unconstrained (covariance between two factors is freely calculated) models based on a chi-square difference test is significant. A significant chi-square difference test in this approach is interpreted as the presence of discriminant validity. All chi-square differences were significant in this research $(\mathrm{P}<0.001)$, indicating an adequate level of discrimination among the factors. The second method relies on the comparison of AVE, Maximum Shared Squared Variances (MSV), and Average Shared Squared Variance (ASV) to calculate the discriminant validity. Following this method, a construct holds enough discriminant validity if the AVE of the construct is bigger than its MSV and ASV. The construct of EH did not pass this test of discriminant validity because its AVE (0.423) was smaller than its MSV (0.448).

However, EH met the adequate conditions of Anderson and Gerbing's (1988) convergent and discriminant validities, it did not satisfy Fornell and Larcker's (1981) requirements. Delving a little deeper into Anderson and Gerbing (1988) shows their approach has mainly relied on significance test statistics to calculate validities. Significance test statistics are very sensitive to sample size, meaning a bigger sample is 123 
more likely to result in a significance test statistic. Because most CFA models need large samples to run accurately, Anderson and Gerbing's (1988) may lead to biased results. Consequently, Fornell and Larcker's (1981) method, in which validities are calculated in terms of variance and covariance, is preferable. Therefore, to reach the adequate convergent and discriminant validity of Fornell and Larcker's (1981) method, another question of $\mathrm{EH}\left(\mathrm{EH} 4{ }^{1}\right.$ with the smallest factor loading) was removed.

Table 4-1: The convergent and discriminant validity of measurements

\begin{tabular}{ccccccll}
\hline & CR & AVE & MSV & ASV & CE & ED & EH \\
\hline EO & 0.959 & 0.886 & 0.317 & 0.118 & $\mathrm{X}^{2}{ }_{\mathrm{d}}=36.26^{* * *}$ & $\mathrm{X}^{2}{ }_{\mathrm{d}}=12.21 * * *$ & $\mathrm{X}^{2}{ }_{\mathrm{d}}=21.68 * * *$ \\
\hline CE & 0.957 & 0.882 & 0.383 & 0.142 & & $\mathrm{X}^{2}{ }_{\mathrm{d}}=66.26^{* * *}$ & $\mathrm{X}^{2}{ }_{\mathrm{d}}=34.71^{* * *}$ \\
\hline $\mathrm{ED}$ & 0.878 & 0.590 & 0.317 & 0.127 & & & $\mathrm{X}^{2}{ }_{\mathrm{d}}=44.77 * * *$ \\
\hline $\mathrm{EH}$ & 0.715 & 0.580 & 0.383 & 0.147 & & \\
\hline${ }^{*} \mathrm{P}<0.05$ & $* * \mathrm{P}<0.01$ & $* * * \mathrm{P}<0.001^{2}$ & & &
\end{tabular}

The composite reliabilities (CR) of all constructs also exceeded the minimum cutoff of 0.6 (Bagozzi \& Youjae, 1988), confirming the reliability of the constructs. All calculations are shown in Table 4-1 (see the appendix for a schematic picture of the CFA model).

\subsubsection{Construct Dimensionality}

After conducting a total confirmatory factor analysis (a model including of all independent and moderator variables) to check the reliability and validity of the research instruments, testing the dimensionality of EO and CE using a comparative model analysis is helpful and instructive. This technique has been previously employed by researchers to discuss the dimensionality of EO (e.g. Anderson et al., 2014; Runyan et al., 2012).

Comparative indices, such as the chi-square difference test, SRMR, CFI, and Expected Cross Validation Index (ECVI) are suitable for performing a model comparison test (Bagozzi \& Youjae, 1988; Byrne \& Gavin, 1996; Byrne \& Shavelson, 1996). These indices are frequently used to discuss the absolute fit of an overall model, or to compare different nested models in terms of their overall fit. Following a comparative model analysis, the goodness-of-fit indices of an initially hypothesized model are compared with

1 The markets of our products is dwindling. 0.001 .

2 The degree of freedom for all X2d is equal to 1; thus, critical values bigger than 6.6349 are significant at the level of 
the fit of a nested alternative model in which the number of factors is less (Byrne \& Shavelson, 1996).

In practice, a chi-square statistical test can be more beneficial if it is regarded as an overall measure implying the fit between a sample covariance matrix and a fitted covariance matrix, rather than as a test statistic (Byrne \& Gavin, 1996; Byrne \& Shavelson, 1996). Therefore, it is helpful to compare the overall fit of two nested models (Bagozzi \& Youjae, 1988) showing which one is better fitted with the sample covariance matrix; however, with regard to its sensitivity to the sample size, it should be interpreted with caution and in the company of other goodness-of-fit indices. ECVI shows the crossvalidation of a model across different similarly sized samples from the same population (Browne \& Cudeck, 1989). This index is used in a rank order to compare nested models, and a model with the smallest value of ECVI has the highest potential for replication (Byrne \& Gavin, 1996; Byrne \& Shavelson, 1996). Table 4-2 exhibits the values of chisquare, CFI, ECVI, SRMR, and the chi-square difference test for the unidimensional and multidimensional models of EO and CE.

Table 4-2: Unidimensional versus multidimensional models of EO and CE

\begin{tabular}{|c|c|c|c|c|c|c|}
\hline Model & $\mathbf{X}^{2}$ & Df & CFI & ECVI & SRMR & $\mathrm{X}^{2}$ difference \\
\hline EO-Unidimensional & 125.01 & 20 & 0.921 & 0.797 & 0.0446 & \multirow{2}{*}{$\begin{array}{l}\mathrm{X}^{2} \mathrm{~d}=101.72 * * * \\
\mathrm{DF}=3\end{array}$} \\
\hline EO-Multidimensional & 23.29 & 17 & 0.995 & 0.331 & 0.0204 & \\
\hline CE-Unidimensional & 453.20 & 77 & 0.836 & 2.585 & 0.0734 & \multirow{2}{*}{$\begin{array}{l}\mathrm{X}^{2} \mathrm{~d}=155.39 * * * \\
\mathrm{DF}=5\end{array}$} \\
\hline CE-Multidimensional & 297.81 & 72 & 0.902 & 1.847 & 0.0703 & \\
\hline
\end{tabular}

The chi-square difference test shows a significant difference between the unidimensional and the multidimensional models of EO $\left(\mathrm{X}^{2}{ }_{\mathrm{d}}=101.72, \mathrm{DF}=3\right)$. The CFI corroborates the chi-square difference test, resulting in a higher model fit for the multidimensional construct of EO. In fact, the unidimensional model of EO does not meet the CFI threshold of 0.95 (Hu \& Bentler, 1998). As shown in the table, the smaller values of ECVI and SRMR, respectively, point to the higher potential of the multidimensional model for replication and prediction. All indices are in favor of the multidimensional model of EO, demonstrating the multidimensional conceptualization as a more fitted construction with the sample data. These statistical calculations support the research 
conceptualization and operationalization of EO as a reflective multidimensional construct including innovativeness, proactiveness, and risk-taking.

Both measurement models of $\mathrm{CE}$, either multidimensional or unidimensional, display a lower model fit than the EO measurement models. However, comparing the multidimensional and unidimensional measurements of CE together, the multidimensional construction including the three dimensions of innovation, venturing and strategic renewal shows a better overall fit. The chi-square difference test significantly differentiates the multidimensional model as a better-fitted model $\left(\mathrm{X}_{\mathrm{d}}{ }=101.72, \mathrm{DF}=3\right)$. CFI also confirms the chi-square difference; while the unidimensional model is not adequately fitted in regard to all the proposed cutoffs, the multidimensional model is fitted considering Byrne and Gavin's (1996) CFI threshold of 0.9. The multidimensional model displays a smaller value of ECVI compared to the unidimensional model, revealing a higher potential of replication (a smaller amount of ECVI compared to the unidimensional model). It also shows a lower amount of residuals (the smaller value of SRMR), which implies a lower error of prediction. These calculations are again in accordance to the conceptual discussion of $\mathrm{CE}$ as a reflective multidimensional measurement.

\subsubsection{Cluster Analysis}

A quick glance at the correlation coefficient of $\mathrm{EO}$ and $\mathrm{CE}$ reveals a modest but significant correlation value (.204 and $\mathrm{P}<.01)$, which is in line with discussing them as two separate constructs that may or may not covary for a given company. Actually, a company could be marked as high or low in both or high in one and low in another. To classify companies in terms of their EO and CE grades, a two-step technique of hierarchical and k-means clustering was applied. This is the most common protocol of cluster analysis (Hagen et al., 2012). The hierarchical technique in the first step allows one to identify the proper number of clusters, while the k-means procedure places all similar cases together to form the best configurations of predefined groups.

Ward's minimum variance method was employed to form the table of agglomeration schedule in hierarchical clustering. The agglomeration coefficient, shown 
in boldface type in Table 4-3, indicates a very sharp rise when moving from four to three clusters; hence, the number four is proposed as the best solution for clustering in this case.

Table 4-3: Cluster analysis

\begin{tabular}{ccc}
\hline $\begin{array}{c}\text { Number of } \\
\text { Clusters }\end{array}$ & $\begin{array}{c}\text { Agglomeration } \\
\text { Coefficient }\end{array}$ & $\begin{array}{c}\text { Changes in Agglomeration } \\
\text { Coefficient }\end{array}$ \\
\hline 1 & 394.000 & \\
\hline 2 & 245.515 & 148.485 \\
\hline 3 & 153.075 & 92.440 \\
\hline $\mathbf{4}$ & $\mathbf{8 1 . 7 8 1}$ & $\mathbf{7 1 . 2 9 4}$ \\
\hline 5 & 61.908 & 19.873 \\
\hline 6 & 52.149 & 9.759 \\
\hline
\end{tabular}

The result of Ward's method corroborates the suggested profile model of firmlevel entrepreneurship. Checking on clustering centroids of standardized data revealed even more promising results; Cluster 1 has a negative centroid of EO but a positive centroid of $\mathrm{CE}$, and seems quite matched with what was expected from a forced entrepreneurial profile. Following this logic, Clusters 2, 3, and 4 are matched with the latent entrepreneurial, the actual entrepreneurial, and the non-entrepreneurial classifications of the proposed profile model.

In the next step, companies were assigned to their appropriate clusters using kmeans techniques. Table 4-4 summarizes the characteristics of the four clusters.

Table 4-4: The statistical descriptions of clusters

\begin{tabular}{lllll}
\hline & $\begin{array}{l}\text { Non- } \\
\text { Entrepreneurial }\end{array}$ & $\begin{array}{l}\text { Latent } \\
\text { Entrepreneurial }\end{array}$ & $\begin{array}{l}\text { Forced } \\
\text { Entrepreneurial }\end{array}$ & $\begin{array}{l}\text { Actual } \\
\text { Entrepreneurial }\end{array}$ \\
\hline EO Centroid & -1.20128 & .69768 & -.71569 & .98329 \\
\hline CE Centroid & -1.39322 & -.93927 & .65141 & .79171 \\
\hline Number of Firms & 31 & 46 & 67 & 54 \\
\hline Size & 22.90 & 29.39 & 30.21 & 48.19 \\
\hline Age & 12.58 & 11.2391 & 15.89 & 14.1852 \\
\hline $\begin{array}{l}\text { International } \\
\text { Involvement }\end{array}$ & $5(16.1 \%)$ & $30(65.2 \%)$ & $66(98.5 \%)$ & $49(90.7 \%)$ \\
\hline International Scale & 3.71 & 18.73 & 56.97 & 27.42 \\
\hline International Scope & .26 & 1.40 & 4.06 & 2.34 \\
\hline $\begin{array}{l}\text { Speed of } \\
\text { Internationalization }\end{array}$ & .0288 & .2070 & .4955 & .2910 \\
\hline
\end{tabular}

At first glance, the forced entrepreneurial companies (forming the biggest cluster) seem faster and more intensive in their internationalization, followed by the actual, latent, 
and finally forced entrepreneurial firms. The latent entrepreneurial companies are the youngest, while the actual entrepreneurial firms hold the largest number of staff.

\subsubsection{Testing the Hypotheses}

Actually, both traditional techniques of ANOVA and multiple regression analysis can be used to test the hypotheses. In this study, multiple regression analysis was employed because of the given limitations of ANOVA strategies (for more information on the limitations of ANOVA techniques, please see Davis (2010, p. 63)). To perform a multiple hierarchical regression, the categorical variable of firm-level entrepreneurship generated by the cluster analysis in the previous step was codified. Selecting a proper coding scheme is very important in this step because different coding schemes yield different types of post-hoc analysis.

Statisticians have developed a number of coding schemes and discussed their pros and cons (e.g. Davis, 2010; O'Grady \& Medoff, 1988; Serlin \& Levin, 1985). Although dummy coding is one of the most frequently used schemes, researchers should be cautioned because it only represents the effect of interests in a limited set of situations (O'Grady \& Medoff, 1988) and affords limited details of hypothesis testing. Another scheme that is very helpful, especially for running a planned comparison between groups, is called contrast coding. This scheme is highly recommended when hypotheses are directed and driven from the literature. Compared to dummy coding, contrast coding leads to more detailed interpretation, a task that if is performed by traditional ANOVA strategies, would need post-hoc tests (Davis, 2010). Implementing different coding schemes does not affect the overall tests of significance (Serlin \& Levin, 1985), but influences the details of explanation and the ease of interpretation. Orthogonal contrast coding is easy to interpret, provides increased statistical power against Type II errors, and helps researchers to be more specific and thoughtful about their hypotheses (Davis, 2010). Consequently, this scheme is applied in this research to codify the categorical variable of firm-level entrepreneurship. The details of this coding scheme for firm-level entrepreneurship are shown in Table 4-5. 
Table 4-5: The contrast coding of firm-level entrepreneurship

\begin{tabular}{ccccc}
\hline & Contrast1 & Contrast2 & Contrast3 & Product \\
\hline $\begin{array}{c}\text { Non- } \\
\text { Entrepreneurial }\end{array}$ & +3 & 0 & 0 & 0 \\
\hline $\begin{array}{c}\text { Latent } \\
\text { Entrepreneurial }\end{array}$ & -1 & +2 & 0 & 0 \\
\hline $\begin{array}{c}\text { Forced } \\
\text { Entrepreneurial }\end{array}$ & -1 & -1 & +1 & +1 \\
\hline $\begin{array}{c}\text { Actual } \\
\text { Entrepreneurial }\end{array}$ & -1 & -1 & -1 & -1 \\
\hline Total & 0 & 0 & 0 & 0 \\
\hline
\end{tabular}

Before interpreting the results of multiple regressions, checking on necessary assumptions is mandatory. Actually, if necessary assumptions are not met, the results of the regression could be unreliable. Normality, multicolinearity, heteroscedasticity and linearity are the most essential preconditions of an accurate multiple linear regression analysis. Histogram and P-P plots of residuals for all regressions were checked, and no noticeable deviation was found from normality. Also, the plot of standardized residual against predicted values displayed a very randomized shape without a sharp sign of funneling or nonlinearity. Consequently, the conditions of normality, heteroscedasticity and linearity are met for all the regression models. The largest amount of Variance Inflation Factor (VIF) and its average value were inspected for multicolinearity (the actual values of VIF are presented in the appendix). The models revealed no multicolinearity because the largest values of VIF were smaller than 10 and their average values were very close to 1 (Bowerman \& O'Connell, 1990).

It is also advised to check the model accuracy, identify outliers and remove influential cases. A regression model is considered accurate if no case has a standardized residual greater than 3.29, and not more than 1 and 5 percent of standard residuals are graded larger than 2.58 and 1.96, respectively (Field, 2013). Although some models in this research exhibited some deviations from these rules, they were not very sizable so they could be ignored. Mahalonobis' and Cook's distances were implemented to identify outliers and the influential cases. Stevens (2009, p. 111) offered excellent advice regarding how to deal with outliers and influential cases using Mahalonobis' and Cook's distances; 
If a point is a significant outlier on $y$, but its Cook distance is $<1$, there is no real need to delete the point because it does not have a large effect on the regression analysis.

Accordingly, this study uses Mahalonobis' distance to identify outliers based on Barnett and Lewis (1978) table of critical values and Cook's distance to remove the influential cases (Cook's distance $>1$ ). Although a number of outliers were identified in each regression model, none of them showed a Cook's distance greater than 1; thereby, no case was removed.

\subsubsection{Firm-level entrepreneurship and international involvement}

Both firm-level entrepreneurship and international involvement scaled as nominal variables. A recommended approach to test the relationship between two nominal variables is crosstab analysis; hence, this technique was employed to test the first hypothesis. Controlling the effect of continuous variables in crosstab analysis is very complicated and sometimes impossible. They need to be converted to categorical variables first. Therefore, the variables of both firm size and previous international experience were converted, each one containing two categories (small and medium for firm size based on the Z-score, and with or without previous international experience). Then, they were entered separately as layer variables in the crosstab analysis to determine if they affected the association of firm-level entrepreneurship and international involvement. There was no difference between small and medium companies in terms of the relationship between firm-level entrepreneurship and international involvement. Also, the data was not adequate to meet the necessary assumption for testing the effect of previous international experience. It is approximately concluded that the control variables do not significantly influenced the relationship of firm-level entrepreneurship and international involvement.

All expected values of the cross tables were greater than five; therefore, the assumptions of the crosstab analysis have been met and the results are trusted. As was expected, the magnitudes of chi-square and the likelihood ratio were nearly the same (because of the big sample size of the research), and both revealed a significant difference between various profiles in terms of international involvement. In addition, the magnitude 
of the difference was moderately high (Phi coefficient $=.668$ and Cramer's $\mathrm{V}=.668$ ). Checking on the percentage of international and non-international companies in each category drew a more detailed explanation. Among all, forced entrepreneurial companies showed the highest degree of international involvement, the actual entrepreneurial group stood in second place, and the non-entrepreneurial companies displayed the lowest degree of international involvement.

Table 4-6: The cross-tab analysis of international involvement

\begin{tabular}{lllll}
\hline & $\begin{array}{c}\text { Non- } \\
\text { Entrepreneurial }\end{array}$ & $\begin{array}{c}\text { Latent } \\
\text { Entrepreneurial }\end{array}$ & $\begin{array}{c}\text { Forced } \\
\text { Entrepreneurial }\end{array}$ & $\begin{array}{c}\text { Actual } \\
\text { Entrepreneurial }\end{array}$ \\
\hline Involve in & $5(23.5 \%)$ & $30(65.2 \%)$ & $66(98.5 \%)$ & $49(90.7 \%)$ \\
\hline $\begin{array}{l}\text { Not } \\
\text { involve in }\end{array}$ & $26(83.9 \%)$ & $16(34.8 \%)$ & $1(1.5 \%)$ & $5(9.3 \%)$ \\
\hline Pearson Chi-Squared & $88.281 * * *(\mathrm{Df}=3)$ & \\
\hline Likelihood Ratio & $88.784 * * *(\mathrm{Df}=3)$ & \\
\hline Phi & .668 & Cramer's V & .668 \\
\hline
\end{tabular}

A three-way log-linear technique with backward elimination was recruited to analyze the moderating effect of environmental dynamism and environmental hostility on the relationship of firm-level entrepreneurship and international involvement. This technique is a higher advanced version of crosstab analysis that follows a backward process to test a more complicated relationship embracing moderating effects. Backward elimination revealed no significant change in the model fit when the three-way interactions of firm-level entrepreneurship, international involvement, and environmental dynamism (chi-square change $=3.998, \mathrm{Df}=3, \mathrm{P}=.263$ ) or firm-level entrepreneurship, international involvement, and environmental hostility (chi-square change $=5.476, \mathrm{Df}=3, \mathrm{P}=.140$ ) were removed. Excluding the two-way interaction of firm-level entrepreneurship and international involvement decreased the model fit significantly in the both models of environmental dynamism (chi-square change $=85.863$, Df $=3, \mathrm{P}<.000$ ) and environmental hostility (chi-square change $=59.952, \mathrm{Df}=3, \mathrm{P}<.000$ ), which again confirmed the results of the crosstab analysis about the meaningful relationship between firm-level entrepreneurship and international involvement. All in all, the log-linear analysis showed that the relationship of firm-level entrepreneurship and international involvement is not moderated by the environmental dimensions of dynamism and hostility. Table 4-7 exhibits the $\mathrm{K}$-way effects of removing the three-way interactions $(\mathrm{K}=3)$, the two-way interactions 
$(\mathrm{K}=2)$, and the main effects $(\mathrm{K}=1)$ from the both models of environmental dynamism and environmental hostility.

Table 4-7: The cross-tab analysis of international involvement and environment

\begin{tabular}{|c|c|c|c|c|c|c|}
\hline & \multirow{2}{*}{$\mathbf{K}$} & \multirow{2}{*}{ DF } & \multicolumn{2}{|c|}{ Likelihood Ratio } & \multicolumn{2}{|l|}{ Pearson } \\
\hline & & & Chi-Square & P-Value & Chi-Square & P-Value \\
\hline \multirow{3}{*}{ 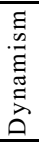 } & 1 & 5 & 70.997 & .000 & 45.611 & .000 \\
\hline & 2 & 7 & 133.730 & .000 & 161.174 & .000 \\
\hline & 3 & 3 & 3.988 & .263 & 2.972 & .396 \\
\hline \multirow{3}{*}{ 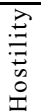 } & 1 & 5 & 73.331 & .000 & 68.032 & .000 \\
\hline & 2 & 7 & 142.621 & .000 & 184.095 & .000 \\
\hline & 3 & 3 & 5.476 & .140 & 4.338 & .227 \\
\hline
\end{tabular}

These results do not support Hypothesis 1, 5A and 5B, respectively, assuming the highest degree of international involvement for actual entrepreneurial companies in whole, dynamic, and hostile environments.

\subsubsection{Firm-level entrepreneurship and international scale}

In contrast to international involvement, international scale is scaled as a continuous variable measured through export ratio of a given company. Thereby, the proper approach to analyze its relation with firm-level entrepreneurship is regression analysis, or ANOVA. As mentioned before, regression analysis is preferable because of the given limitations of ANOVA strategies. The regression analysis applied in this research followed a hierarchical approach. The control variables (company size and previous international experience) were entered at the first step, independent variable (firm-level entrepreneurship) at the second, and moderating variables (the interaction effects) at the third into the regression analysis. The details of all regression models have been summarized in Table 4-8.

The first four columns of the table demonstrate the hierarchical regression analysis of the international scale. Model 1 shows that firm size and previous international experience are not significantly related. The R-square of the model also demonstrates that these two variables only explain about .6 percent of the international scale variance, which is very close to zero. Also, a quick glance at the adjusted R-square revealed a very low 
cross-validation of a model including only the sample size and the previous international experience (the adjusted R-square is negative).

The R-square of Model 2 is moderately high. It shows that about 56 percent of international scale variance could be explained by firm-level entrepreneurship and control variables; however, the part played by firm-level entrepreneurship in explaining the variance is much greater than firm size and previous international experience $(\Delta \mathrm{R}$-square of $.555, \mathrm{P}<0.001)$. The adjusted R-square of the model is about .550 , which implies a high degree of cross-validation. These calculations confirm a significant difference between four classifications of the profile model in terms of international scale. Further analysis based on the contrast coding and the effect sizes (values in the brackets) shed more light on the details. Comparing the individual profiles one by one show a significant difference between the entrepreneurial and non-entrepreneurial $(.514, \mathrm{P}<0.001)$, the latent entrepreneurial and other entrepreneurial $(.471, \mathrm{P}<0.001)$, and the forced entrepreneurial and actual entrepreneurial companies $(.544, \mathrm{P}<0.001)$. Although the sign of the beta coefficients uncovers the first clue about the direction of these differences, double-checking Table 4-4 could be more enlightening. Among all types, the forced entrepreneurial companies showed the highest international scale, followed by the actual, the latent, and the non-entrepreneurial companies.

On the whole, the regression analysis shows a significant overall difference among the four types of companies in respect to their international scale. The entrepreneurial companies (the profiles displaying some kind of entrepreneurial orientation or behavior) exhibit a significantly higher degree of international scale than the non-entrepreneurial firms (a type of company in which both entrepreneurial orientation and entrepreneurial behavior are low). Among entrepreneurial companies, the actual and forced entrepreneurial are more internationalized compared to the latent entrepreneurial companies, and when only the actual and forced entrepreneurial types are brought into comparison, the forced entrepreneurial companies show a higher scale of internationalization. This conclusion does not entirely match what was inferred and summarized in Hypothesis 2. 
Model 3 and Model 4 of the international scale respectively add the moderating effects of environmental dynamism and environmental hostility to the analysis. Including environmental dynamism as a moderator did not change the R-square significantly, and all the interaction terms were also insignificant. These results describe environmental dynamism as a neutral moderator that does not influence the relationship of firm-level entrepreneurship and international scale. Therefore, Hypothesis 6A is not supported. 


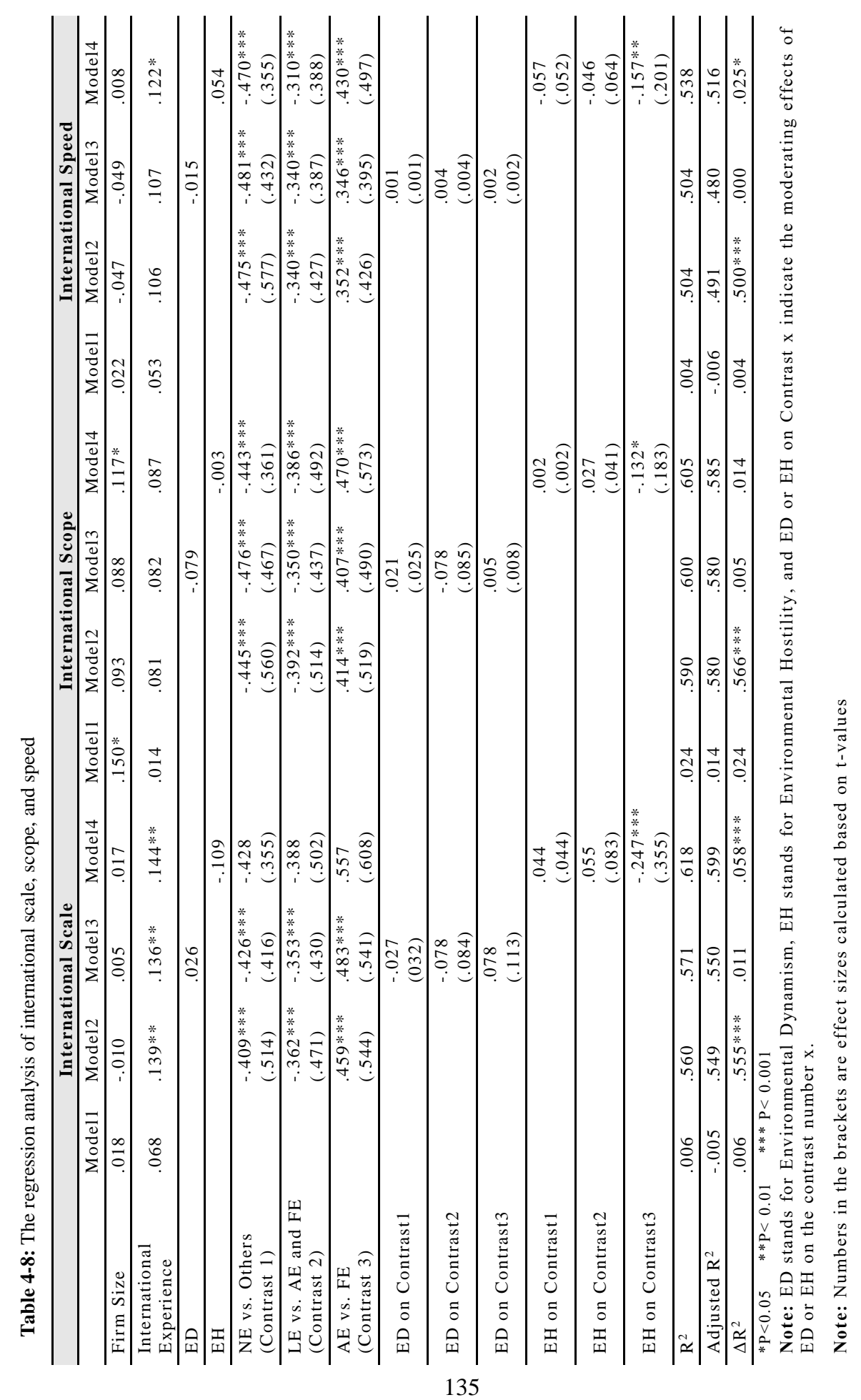


Environmental hostility behaved similarly when the non-entrepreneurial with the entrepreneurial, or the latent entrepreneurial with the forced and the actual entrepreneurial companies were compared. It did, however, significantly influence the third contrast in which the forced-entrepreneurial and actual entrepreneurial profiles were placed against each other. The overall change of the R-squared in Model 4 is significant, which corroborates with the regression coefficient analysis demonstrating a significant improvement in the fit and the power of the model when the environmental hostility is added as the moderator. If the interaction effects of the environmental hostility are entered in a stepwise procedure and the specific change of the R-square of each interaction is regularly checked, interesting results will emerge. It clearly shows that the overall change of the R-square $(.058, \mathrm{P}<0.001)$ originates from the $\mathrm{R}$-square change raised from adding the environmental hostility to the third contrast (comparing the forced and actual entrepreneurial firms $(.048, \mathrm{P}<0.001)$ ), not the first (comparing the non-entrepreneurial and entrepreneurial firms $(.000, \mathrm{P}<.704)$ ) or the second (comparing the latent with the forced and actual entrepreneurial companies $(.001, \mathrm{P}<0.466))$. In summary, the regression models demonstrate that environmental hostility significantly influences the international scale of the forced and actual entrepreneurial companies, but does not affect the non-entrepreneurial and latent entrepreneurial firms.

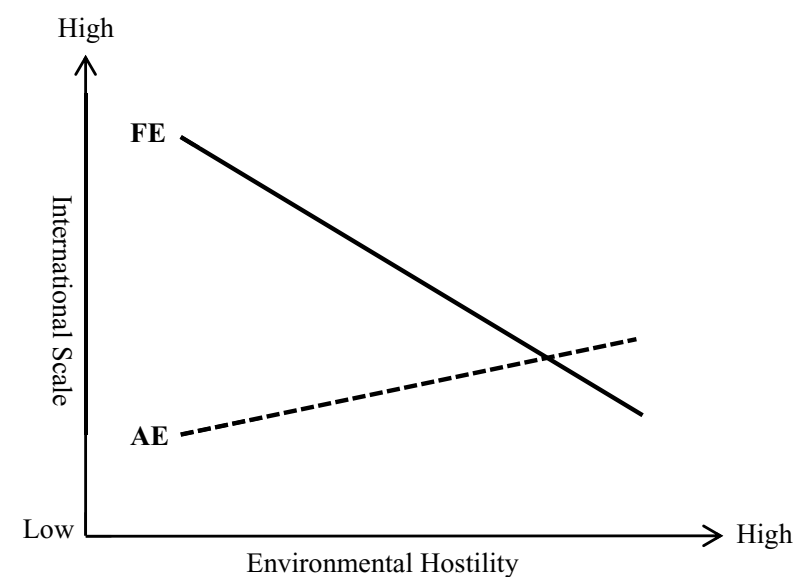

Figure 4-1: The simple slope analysis of the international scale and environmental hostility (FE vs. AE) 
To find out which type - the forced entrepreneurial or the actual entrepreneurial profile - discloses a higher degree of international scale in a hostile environment, a simple slope analysis was conducted. As Figure 4-1 exhibits, when the hostility increases the degree of international scale of the forced entrepreneurial companies decreases, but the degree of international scale of the actual entrepreneurial firms increases. The decline of the international scale of the forced entrepreneurial profile proceeds at a faster pace than the slope of the actual entrepreneurial type. At a certain level of environmental hostility (the crossing point in Figure 4-1), the international scale of the actual entrepreneurial exceeds the international scale of the forced entrepreneurial group. In other words, in a very hostile environment (when the level of hostility goes beyond the crossing point), the actual entrepreneurial companies display a higher degree of international scale than the forced entrepreneurial firms. This conclusion supports Hypothesis 6B, which supposed actual entrepreneurial companies would reveal the highest degree of international scale in hostile environments.

\subsubsection{Firm-level Entrepreneurship and International Scope}

The regression analysis of the international scope yielded the same results as the international scale. First, the R-square significantly changed when the firm-level entrepreneurship was added. Including the firm-level entrepreneurship in Model 1 improves the R-square dramatically. The overall R-square of Model 2 is about 58 percent, showing a significant improvement over Model $1(\mathrm{R}$-square change $=.566, \mathrm{P}<0.001)$ and confirming that firm-level entrepreneurship is able to explain about 56.6 of the variance of international scope. The adjusted R-square of .580 implies a high cross-validity of the model, allowing the generalizability of data.

The difference between the non-entrepreneurial and the entrepreneurial companies in terms of the number of foreign countries is significantly high $(.560, \mathrm{P}<0.001)$. This means that the companies with high level of entrepreneurial behavior or entrepreneurial orientation sell their products in more foreign markets than the non-entrepreneurial companies. In the same vein, the actual and the latent entrepreneurial firms market their products in a larger number of countries compared to the latent entrepreneurial companies (.514, $\mathrm{P}<0.001)$. Looking at the last contrast, when only the forced and the actual 
entrepreneurial companies are in focus, the forced entrepreneurial companies are revealed as the more internationalized group in term of scope $(.519, \mathrm{P}<0.001)$. On the whole, the forced entrepreneurial companies sell their products in more international markets than all other groups. This is not completely in accordance with Hypothesis 3, which expected the actual entrepreneurial firms to show the highest scope of internationalization.

Adding environmental dynamism to the analysis (Model 3) did not significantly change the R-square $(.005, \mathrm{P}=.502)$. Also, none of the interaction coefficients of the contrasts were statistically significant. Consequently, Hypothesis 7A is not supported. It is concluded that the environmental dynamism does not moderate the relationship of the firm-level entrepreneurship and the international scope.

The case of the environmental hostility is different. The overall change of the Rsquare is not significant $(.014, \mathrm{P}=.093)$, but running a stepwise regression on the interaction terms divulges a significant R-square for the effect of the environmental hostility on Contrast 3, comparing the international scope of the actual and the forced entrepreneurial companies $(.014, \mathrm{P}<0.05)$. Comparing the overall change of the R-square and the R-square change resulting from the moderating effect of the environmental hostility on the Contrast 3 provides an informative conclusion. It shows all the change in the overall R-square originated from the interaction term of the environmental hostility and the Contrast 3. Actually, the level of the environmental hostility does not really influence the international scope when Contrast 1 (the entrepreneurial versus the nonentrepreneurial) or Contrast 2 (the latent entrepreneurial versus the forced and the actual entrepreneurial) are at the center of attention. It is only significant when the international scopes of the forced and the actual entrepreneurial firms are compared.

The significant regression coefficient of the environmental hostility on Contrast 3 $(.183, \mathrm{P}<0.05)$ corroborates the stepwise $\mathrm{R}$-square change procedure, confirming the importance of the environmental hostility in the international scope of the forced and actual profiles. The simple slope analysis clarifies the details and direction of the effect. It shows that the international scopes of the forced and actual entrepreneurial companies respectively fall and grow at almost the same grade when the hostility of the environment increases, and in a very hostile environment, the actual entrepreneurial companies surpass 
the forced entrepreneurial firms. This inference supports Hypothesis 7B, which featured the highest degree of international scope for the actual entrepreneurial companies in a hostile environment.

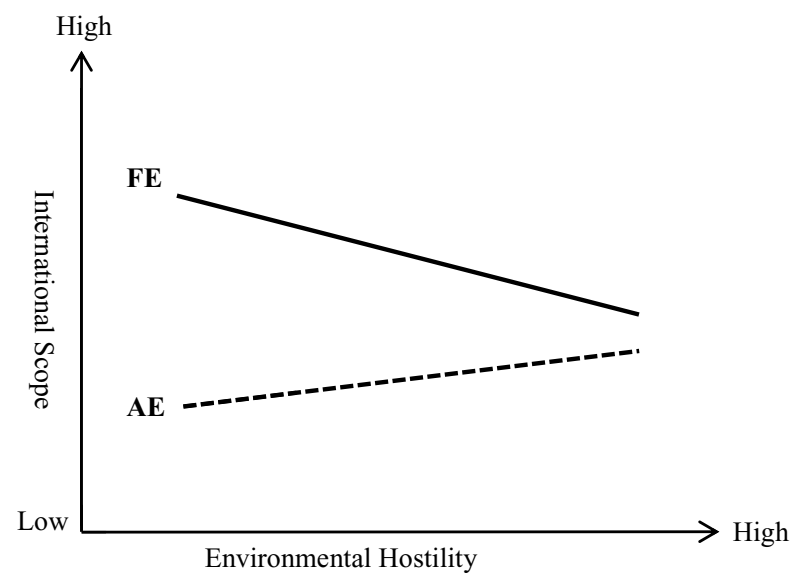

Figure 4-2: The simple slope analysis of the international scope and environmental hostility (FE vs. AE)

\subsubsection{Firm-level Entrepreneurship and the Speed of Internationalization}

Similar to the international scale and scope, the control variables displayed a poor and insignificant potential to explain the variance of the speed of internationalization (Rsquare $=.004, \mathrm{P}=.683$ ). Adding the firm-level entrepreneurship to the model significantly improved the power of the regression analysis ( $\mathrm{R}$-square change $=.500, \mathrm{P}<0.001$ ), with a fairly good potential for cross-validation (Adjusted R-square $=.491$ ). The regression coefficients and the effect sizes of Contrast 1, Contrast 2, and Contrast 3 confirmed meaningful differences between the non-entrepreneurial versus the entrepreneurial companies $(.577, \mathrm{P}<0.001)$, the latent versus the forced and the actual entrepreneurial firms $(.427, \mathrm{P}<0.001)$, and the forced versus the actual entrepreneurial profiles $(.426, \mathrm{P}$ $<0.001)$. In general, it is concluded that among all types of companies, the forced entrepreneurial firms are the fastest in their internationalization process. This conclusion does not perfectly confirm Hypothesis 4, which assumed the actual entrepreneurial cluster as the fastest group in terms of the speed of internationalization. 
Adding environmental dynamism did not significantly improve the power of the regression model ( $\mathrm{R}$-square change $=.000 \mathrm{P}=1.000)$. All regression coefficients were also insignificant, which confirms no moderating effect of the environmental dynamism on the relationship of the firm-level entrepreneurship and the speed of internationalization. Therefore, Hypothesis $8 \mathrm{~A}$ is not supported. The environmental hostility, in contrast, significantly improved the power of the regression model (R-square change $=.025, \mathrm{P}<$ $0.05)$, especially because of the role that it played on the speed of internationalization of the forced and the actual entrepreneurial companies $(.201, \mathrm{P}<0.01)$. As it is exhibited in Figure 4-3, when the environment is benign, the forced entrepreneurial companies show the fastest pace of internationalization, but when the hostility increases, the speed of internationalization of the actual entrepreneurial companies augments and suppresses the forced entrepreneurial firms.

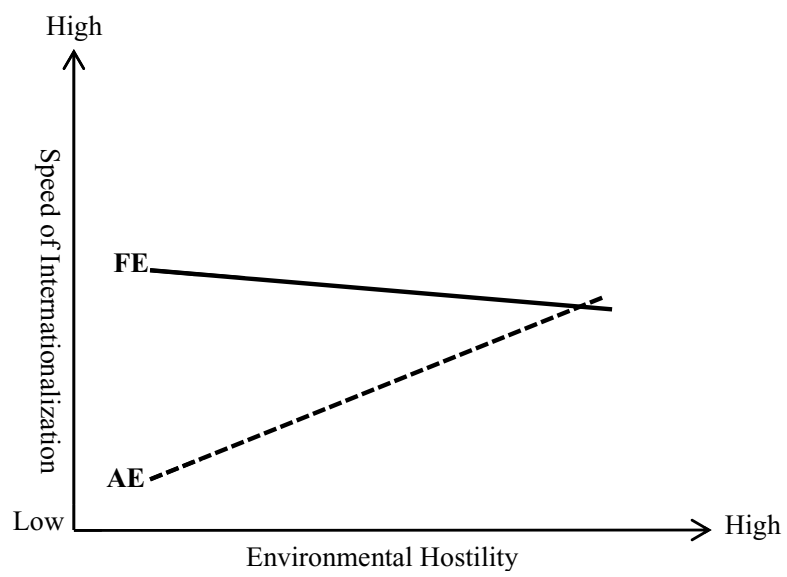

Figure 4-3: The simple slope analysis of the speed of internationalization and environmental hostility (FE vs. AE)

In short, the regression analysis results in a significant relationship between firmlevel entrepreneurship and the speed of internationalization, however the forced entrepreneurial companies are the fastest type in terms of the speed. Further analysis shows no moderating effect for the environmental dynamism, but a significant moderating effect for the environmental hostility. This means that in a hostile environment, the actual entrepreneurial companies surpass the forced entrepreneurial companies and enter 
international markets sooner than the other types of firms. In the aggregate, Hypothesis $8 \mathrm{~B}$, which expected the actual entrepreneurial companies to be the fastest group in terms of the speed of internationalization when the environment becomes hostile, is supported.

Table 4-9: The results of the hypotheses testing

\begin{tabular}{|c|c|c|c|}
\hline Index & Hypothesis & Result & Description \\
\hline Hypothesis 1 & $\begin{array}{l}\text { Actual entrepreneurial companies } \\
\text { are expected to display the highest } \\
\text { degree of international } \\
\text { involvement }\end{array}$ & $\begin{array}{c}\text { Not } \\
\text { supported }\end{array}$ & $\begin{array}{l}\text { Forced entrepreneurial } \\
\text { companies showed the highest } \\
\text { degree of international } \\
\text { involvement }\end{array}$ \\
\hline Hypothesis 2 & $\begin{array}{l}\text { Actual entrepreneurial companies } \\
\text { are expected to display the highest } \\
\text { degree of international scale }\end{array}$ & $\begin{array}{c}\text { Not } \\
\text { supported }\end{array}$ & $\begin{array}{l}\text { Forced entrepreneurial } \\
\text { companies showed the highest } \\
\text { degree of international scale }\end{array}$ \\
\hline Hypothesis 3 & $\begin{array}{l}\text { Actual entrepreneurial companies } \\
\text { are expected to display the highest } \\
\text { degree of international scope }\end{array}$ & $\begin{array}{c}\text { Not } \\
\text { supported }\end{array}$ & $\begin{array}{l}\text { Forced entrepreneurial } \\
\text { companies showed the highest } \\
\text { degree of international scope }\end{array}$ \\
\hline Hypothesis 4 & $\begin{array}{l}\text { Actual entrepreneurial companies } \\
\text { are expected to display the fastest } \\
\text { speed of internationalization }\end{array}$ & $\begin{array}{c}\text { Not } \\
\text { supported }\end{array}$ & $\begin{array}{l}\text { Forced entrepreneurial } \\
\text { companies showed the fastest } \\
\text { speed of internationalization }\end{array}$ \\
\hline Hypothesis 5A & $\begin{array}{l}\text { In dynamic environments, actual } \\
\text { entrepreneurial companies are } \\
\text { expected to display the highest } \\
\text { degree of international } \\
\text { involvement }\end{array}$ & $\begin{array}{c}\text { Not } \\
\text { supported }\end{array}$ & $\begin{array}{l}\text { Forced entrepreneurial } \\
\text { companies showed the highest } \\
\text { degree of international } \\
\text { involvement in dynamic } \\
\text { environments. }\end{array}$ \\
\hline Hypothesis 5B & $\begin{array}{l}\text { In hostile environments, actual } \\
\text { entrepreneurial companies are } \\
\text { expected to display the highest } \\
\text { degree of international } \\
\text { involvement }\end{array}$ & $\begin{array}{c}\text { Not } \\
\text { supported }\end{array}$ & $\begin{array}{l}\text { Forced entrepreneurial } \\
\text { companies showed the highest } \\
\text { degree of international } \\
\text { involvement in hostile } \\
\text { environments. }\end{array}$ \\
\hline Hypothesis 6A & $\begin{array}{l}\text { In dynamic environments, actual } \\
\text { entrepreneurial companies are } \\
\text { expected to display the highest } \\
\text { degree of international scale }\end{array}$ & $\begin{array}{c}\text { Not } \\
\text { supported }\end{array}$ & $\begin{array}{l}\text { Forced entrepreneurial } \\
\text { companies showed the highest } \\
\text { degree of international scale in } \\
\text { dynamic environments. }\end{array}$ \\
\hline Hypothesis 6B & $\begin{array}{l}\text { In hostile environments, actual } \\
\text { entrepreneurial companies are } \\
\text { expected to display the highest } \\
\text { degree of international scale }\end{array}$ & Supported & $\begin{array}{l}\text { Actual entrepreneurial } \\
\text { companies showed the highest } \\
\text { degree of international scale in } \\
\text { hostile environments. }\end{array}$ \\
\hline Hypothesis 7A & $\begin{array}{l}\text { In dynamic environments, actual } \\
\text { entrepreneurial companies are } \\
\text { expected to display the highest } \\
\text { degree of international scope }\end{array}$ & $\begin{array}{c}\text { Not } \\
\text { supported }\end{array}$ & $\begin{array}{l}\text { Forced entrepreneurial } \\
\text { companies showed the highest } \\
\text { degree of international scope in } \\
\text { dynamic environments. }\end{array}$ \\
\hline Hypothesis 7B & $\begin{array}{l}\text { In hostile environments, actual } \\
\text { entrepreneurial companies are } \\
\text { expected to display the highest } \\
\text { degree of international scope }\end{array}$ & Supported & $\begin{array}{l}\text { Actual entrepreneurial } \\
\text { companies showed the highest } \\
\text { degree of international scope in } \\
\text { hostile environments. }\end{array}$ \\
\hline Hypothesis 8A & $\begin{array}{l}\text { In dynamic environments, actual } \\
\text { entrepreneurial companies are } \\
\text { expected to display the fastest } \\
\text { speed of internationalization }\end{array}$ & $\begin{array}{c}\text { Not } \\
\text { supported }\end{array}$ & $\begin{array}{l}\text { Forced entrepreneurial } \\
\text { companies showed the fastest } \\
\text { speed of internationalization in } \\
\text { dynamic environments. }\end{array}$ \\
\hline Hypothesis 8B & $\begin{array}{l}\text { In hostile environments, actual } \\
\text { entrepreneurial companies are } \\
\text { expected to display the fastest } \\
\text { speed of internationalization }\end{array}$ & Supported & $\begin{array}{l}\text { Actual entrepreneurial } \\
\text { companies showed the fastest } \\
\text { speed of internationalization in } \\
\text { hostile environments. }\end{array}$ \\
\hline
\end{tabular}


Unexpectedly, the majority of the hypotheses were not supported and in most cases, the forced entrepreneurial companies revealed a better international performance or a faster speed of internationalization. Table 4-9 summarizes all the hypotheses and the results of the empirical testing. It also provides a short description showing which type is the winner. The inherent problems of the measurement models or unstudied variables that may interfere and affect the dependent variables could be seen as the reasons for these unexpected conclusions. Removing a part of the variance is a big challenge in profile measurement models. Actually, a profile measurement model applies a nominal or ordinal scale that is less powerful than interval or ratio scales. In the process of changing the scale to match the profile modeling, it loses part of its power. Despite this shortage, this type of measurement proposes a better solution for modeling the firm-level entrepreneurship (for more detail, see Chapter Two, Section Seven). Intervening variables could also result in such unexpected conclusions. Throughout the literature, network activities are frequently referred to as an important factor that could affect SMEs' internationalization. The next section of the research delves deeply into network activities and their influence on internationalization.

\subsection{Network Analysis of Case Studies}

To analyze the qualitative data collected from the cases, having an analytical framework which helps to translate the primary data into a meaningful theoretical interpretation is needed. An intensive review of the theoretical and methodological literature in such cases could be instructive and helpful, but it is not enough. Actually, an interactive process of the literature and field data that continuously connects the empirical data to the theoretical literature is more suitable and affords a more accurate framework. To design the analytical framework, a primary worksheet was designed based on the literature and checked with the forced entrepreneurial company. Following insightful discussions and observations, and referring to the literature in an interactive way, the worksheet was modified several times and finally confirmed for performing the interview with other cases. The final analytical framework was designed as a three-step process, which captured actor type, network density, and structural holes as the essential parts of the analysis. 


\subsubsection{Homophily Theory}

Network analysis incorporates network data such as characteristics of the whole network, centrality, equivalence, and subgroups with the non-network attributes of actors such as demographic or personality features (Borgatti, Everett, \& Johnson, 2013) to represent a whole picture of the target subject. The main concern in this research is the internationalization of SMEs; therefore, identifying the influential attributes of the actors, which may affect the collective behavior in a way that improves the international activities of SMEs is the first part of the analytical framework.

One of the frequently discussed phenomena in the network literature is called homophily. It refers to the tendency of actors to attract and bond with others who possess similar attributes (McPherson, Smith-Lovin, \& Cook, 2001). Homophily is an important theoretical antecedent of dyadic social embeddedness (Kim \& Skvoretz, 2013). Firstly, it describes why international firms choose other international companies as their partners. Actually, most international companies tend to choose a partner from an ingroup, even at the cost of short-term efficiency (Zhou, 2011). Secondly, it explains why a company is born in or enters an international network. In such cases the reference point of homophily is not internationalization itself, but the company has another attribute in common which acts as the basis of the cooperation, and internationalization emerges as a collateral effect. The latter application of the homophily phenomenon in internationalization has been implicitly discussed in the theories that look at markets and industries as networks of embedded firms (e.g. Johanson \& Mattsson, 1988; Johanson \& Vahlne, 2006).

Johanson and Mattsson's (1988) network theory views companies as embedded entities in an industrial system, which in turn is a network of inter-organizational relationships. Industrial systems and companies themselves are further divided into international and domestic groups. This division acts as a basis to classify firms and explain their internationalization using a network-based explanation. That part of the theory, which features industrial systems as international and non-international, is a central consideration of this research. Companies need to obtain proper knowledge and necessary information to enter a new foreign market (Sapienza, De Clercq, \& Sandberg, 2005; Yu, Gilbert, \& Oviatt, 2011), and both can be acquired by placement in a highly 
internationalized industrial system that facilitates secure sharing of knowledge and information. Therefore, firms that operate in a highly internationalized industrial system may possess a "learning advantage", and it is easier for them to enter international markets than companies whose exchange partners are mostly domestic (Bell, 1995; Majkgård \& Sharma, 1998). In a study of German biotech firms, Al-Laham and Souitaris (2008) found the presence of international companies in a local cluster as an influential factor for the internationalization of biotech firms. To conclude, the number of international members in a firm's network, which is called the internationalization degree of the network, fundamentally influences the decision to enter a foreign market and other subsequent international activities.

\subsubsection{Structural Holes Theory}

Structural holes (Burt, 1992, 2000, 2001a) or arbitrage theory (Borgatti et al., 2013) is a network theory which explains how business opportunities are explored through networks. This theory emphasizes the network position of a broker who mediates two or more unconnected actors or groups (Burt, 1992). This positioning yields the broker the advantage of identifying or developing new opportunities through combining disconnected pools of information (Burt, 2001b; Hargadon \& Sutton, 1997). Actually, an individual who is in a position to bridge unconnected people or groups enjoys a structural hole position, which affords the advantages of exploring entrepreneurial opportunities ahead of others. This theory has been supported by a number of empirical studies which demonstrate the desired benefits of brokering unconnected actors in an overall network (e.g. Burt, 1997; Mizruchi \& Stearns, 2001; Seibert, Kraimer, \& Liden, 2001; Simon \& Galunic, 2004).

A broker can access superior information by means of structural holes and can exercise a form of control over other actors in the network via filtering and handling that information. If all actors in a given network simultaneously span their structural holes, opportunities that are discovered or created by the brokerage behavior of an actor may be reduced or canceled out by the brokerage behavior of other actors, and a zero-sum game will occur (Buskens \& van de Rijt, 2008). In such conditions, the structure of the network 
is not in the favor of any member and all actors may lose the expected benefits of their structural holes. All in all, a spare network that is not dominated by the logic of zero-sum games could afford the benefits of information and control for the broker who bridges the structural holes. Since knowledge is partially expanded through firm interaction (Nahapiet \& Ghoshal, 1998), actors who bridge structural holes can enjoy timely information from non-redundant contacts, which enable them to develop new understandings regarding emerging opportunities. In addition, being in a brokerage position produces the advantage of controlling other actors by monitoring and filtering the information that they receive. In short, a brokerage position in a spare network opens a window to entrepreneurial opportunities, improves the efficiency of managing and taking benefit of networks, and delivers an advantageous controlling power over other actors.

Opportunity recognition, as a highly subjective process (Venkataraman, 1997), is strongly influenced by the presence of entrepreneurs in social and business networks (Aldrich \& Zimmer, 1986; Johanson \& Mattsson, 1988; Loane \& Bell, 2006). Actually, it is the richness of a network in terms of structural holes or the redundancy of existing ties that determines the potential to identify entrepreneurial opportunities (Aldrich \& Zimmer, 1986). This idea has been tested and verified by several studies on entrepreneurship and internationalization. For instance, Komulainen, Mainela, and Tähtinen (2006) found that most valuable exchange opportunities are identified through existing connections with researchers, innovators, and others who are interested in a peculiar technology. In another study, Zain and $\mathrm{Ng}$ (2006) concluded that companies can identify international opportunities through acquiring information from their networks of actors. As Crick and Spence (2005) reported, 7 out of 12 investigated companies had recognized their business opportunities using social or business connections. There is also a flurry of other studies which highlighted the importance of social and business ties in recognizing international opportunities (e.g. Ellis \& Pecotich, 2001; Harris \& Wheeler, 2005; Loane \& Bell, 2006).

Moreover, opportunities that are identified using social or business connections lead to a better and more fruitful exchange than the opportunities that are driven from geographical, psychic, or linguistic distance advantages. In reality, an entrepreneur who bridges more structural holes is more likely to identify a tie-based international 
opportunity, while others who do not enjoy a brokerage position rely on attending international exhibitions or advertising to discover international opportunities (Ellis, 2011). Altogether, companies that span more structural holes access non-redundant information from foreign markets (Ellis \& Pecotich, 2001), identify more international opportunities in terms of both the number (Ozgen \& Baron, 2007) and the quality, and display better improvement in their corporate performance (Zaheer \& Bell, 2005).

From a technical point of view, redundancy can occur under two major criteria; redundancy by cohesion and redundancy by structural equivalence (Burt, 1992). In the exact words of Burt (1992, p.66);

Under the cohesion criterion, two contacts are redundant to the extent that they are connected by a strong relationship. A strong relationship indicates the absence of a structural hole. Structural equivalence is a useful second indicator for detecting structural holes. Two people are structurally equivalent to the extent that they have the same contacts. Regardless of the relation between structurally equivalent people, they lead to the same sources of information and so are redundant.

Figure 4-4 shows a schematic picture of both types of redundancy.

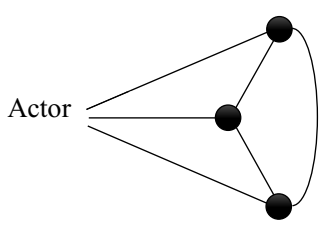

Redundancy by Cohesion

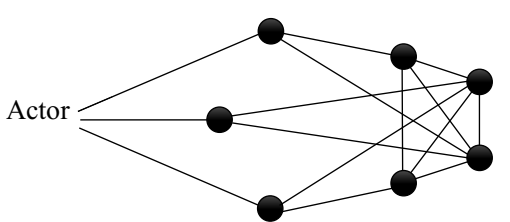

Redundancy by Structural Equivalence

Figure 4-4: The structural indicators of redundancy (Adopted from Burt (1992))

It is true to say, in a given network, that an actor with a lower number of redundant ties enjoys a higher level of structural holes. Therefore, a researcher can estimate the amount of structural holes by calculating the cohesion and structural equivalence of the redundancy. Another dimension of a network that can be explained in terms of redundancy is network efficiency. It refers to maximizing the number of non-redundant ties in a network. Consequently, an efficient network is able to supply the maximum amount of 
novel information or affords the highest number of opportunities at a given level of cost. Summing up, the indicators of cohesion and structural equivalence are being used to calculate the amount of structural holes and network efficiency. A network could be called efficient if it supplies the maximum level of non-redundant information.

\subsubsection{Network Closure Theory}

Another network theory that is helpful in explaining the behavior of small entrepreneurial firms is network closure (Coleman, 1988, 1990), or social resource theory (Borgatti et al., 2013). Opposite to structural holes, this theory focuses on the advantages of performing in a dense network. According to this theory, actors in densified networks trust each other more because the closures enable them to identify and respond to opportunistic behavior faster and more effectively (Coleman, 1988, 1990; Granovetter, 1985).

Burt (1999) criticized the trust advantage of dense networks by proposing the gossip argument. He discussed how the members of a dense network are more prone to gossip, which might increase or decrease trust. In other words, the presence of trust or distrust is determined by gossip, and network density just amplifies their effects because the same information reaches an actor over and over again. Consequently, a researcher should check which one is more dominant in a network before discussing the benefits of network closure. Burt (1999) suggested to collect data on a sample, including actors embedded in both direct and indirect third-party weak ties; if the level of trust is higher in the direct third-party ties, then the gossip argument will be rejected in favor of network closure. This technique seems more beneficial for surveys. In case studies, an in-depth interview, which could uncover the direction of the trust in a network, seems more applicable.

A dense network facilitates collaboration (Burt, 2001a), increases knowledge sharing (Hansen, 1999), improves resource pooling (Adler \& Kwon, 2002), enhances interfirm flexibility (Faems, Janssens, Madhok, \& Van Looy, 2008), boosts the aggregate performance (Balkundi \& Harrison, 2006), and prolongs inter-organizational relationships (Inkpen \& Currall, 2004). It also heightens the mutual understanding among companies and lessens the potential misinterpretation of a firm's actions by other actors in the 
network (Ahuja, 2000; Dyer \& Nobeoka, 2000). Trust plays an important role in the network models of internationalization (Johanson \& Vahlne, 2006; Vahlne, Ivarsson, \& Johanson, 2011), and is highly emphasized as a mechanism that helps companies to manage their conflict with international partners (Svejenova, 2006). Networks equip new international ventures with a fundamental competitive advantage (Oviatt \& Mcdougall, 1994) and directly influence their internationalization (Harris \& Wheeler, 2005).

In essence, actors in dense networks develop a higher degree of interpersonal trust than members of a group that span structural holes because detecting opportunistic behavior in dense networks is easier. In such networks, a deleterious climate that reduces the perception of autonomy in each member is unlikely (Costa, 2003), and the cost of monitoring other actors is low (Zaheer \& Venkatraman, 1995). To benefit from the performance implications of firm-level entrepreneurship identifying opportunities is not enough, and companies need to access external resources to exploit those opportunities (Wiklund \& Shepherd, 2005). Trust, arising from network closure, plays a fundamental role in bringing complementary resources to the internal firm's boundaries, reducing the resource and intra-group transaction cost and establishing the economics of scale and scope (Guillen, 2000; Li \& Zhou, 2010; Thorgren, Wincent, \& Eriksson, 2011; Yiu, Bruton, \& Lu, 2005); thus, it helps entrepreneurs to exploit opportunities in a faster and more effective way (Luo, 2003). This is especially important for SMEs that are facing a number of size-related limitations (Gomes- Casseres, 1997). It is considered a fundamental strategy for uncertain international markets in which the sharing of technologies and resources can greatly reduce cost (Cadogan, Kuivalainen, \& Sundqvist, 2009).

\subsubsection{A Network Analytical Framework}

Homophily theory explains why a cluster is usually made up of companies that share some specific attributes. The attributes in common, or the homophily idea, is the first thing that should be considered when studying internationalization from the network perspective. Homophily theory describes why a company teams up with other partners who are performing in a similar industrial system. Obviously, a company that is located in an 
industrial system with a large number of international members is more likely to receive proper information regarding foreign markets. Accessing relevant information, in turn, facilitates making a timely decision to enter a new attractive market. In contrast, if the proportion of the international companies in an industrial system is low, meaning it contains a large number of domestic members, then a company in that industrial system receives more information about domestic rather than international markets, which encourages the company to stay in its domestic market. In short, the homophily theory justifies the clustering of similar companies, actors who have specific features in common. If a large number of actors that a company forms a cluster with are international firms, then it is more likely that the company will receive proper information and make a decision to engage in international markets.

The subsequent performance of a company which has decided to enter an international market is also influenced by the network structure. As formerly discussed, structural holes help a company to effectively identify opportunities, while, having a dense network facilitates opportunity exploitation by sharing resources and production equipment. The idea of combining the structural holes and the network closure in a way that resolves their conflicts is discussed under the title of structural autonomy (Burt, 1992). In some cases, the personal benefits of an actor who takes the brokerage position could mean losses for others (Buskens \& van de Rijt, 2008), but this is not always true: there are some brokers who establish a win-win situation that works well for all actors in a network. This all-beneficial brokerage can be especially seen in the clustering of smaller companies when they group to act as a whole body against larger firms. The network autonomy resolves the conflict of the structural holes and the network closure by dividing a whole network into internal and external structures (Burt, 1992, 2000). Therefore, a broker in a network deals with two types of actors: the actors who belong to a given business cluster (the internal network), and the others who are outside the business cluster but exchange with the members (the external network). The structural autonomy accounts for the optimized structure as a network in which a few powerful brokers mediate a dense internal and some external networks rich with structural holes. The external network, full of structural holes, puts brokers in a position to identify opportunities ahead of competitors, 
and being a member of the closed internal network is a significant factor to exploit those opportunities. This idea has been displayed as a fourfold square model in Figure 4-5. As shown in the figure, a company that is located in a network of closed internal relationships and spare external structure performs better than those which do not hold these advantages. In short, "while brokerage across structural holes is the source of added value, closure can be critical to realizing the value buried in the structural holes" (Burt, 2001b, p. 25). This theory is an exact sort of multi-level network analysis, which is highly recommended to devote more empirical attention to (Brass, Galaskiewicz, \& Greve, 2004; Moliterno \& Mahony, 2011).

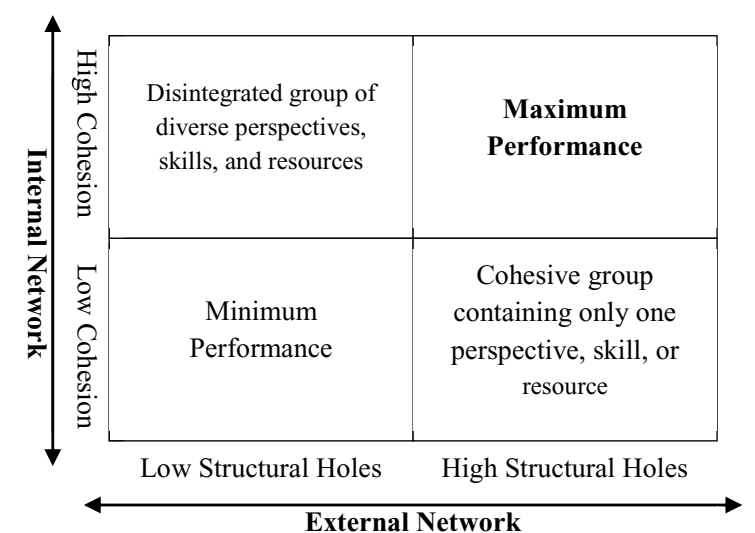

Figure 4-5: The optimized network of structural holes and closure (Adopted from Burt (2000, 2001b))

The idea of network autonomy was tested and confirmed by a number of empirical studies. For example, Oh, Labianca, and Chung (2006) and Reagans and Zuckerman (2001) suggested that a team acts better if brokers span structural holes outside the group to bring novel information for the benefit of all members. Reagans and Zuckerman (2001) reported a higher level of performance for organizational units in which scientists, who hold a spare network of outside relationships, were working in a team with a high level of network closure. In a study of medieval Maghribi traders in North Africa, Greif (1989) described network closure as the source of trust that allowed the traders to coordinate their different business activities in a way that benefitted all. Maghribi traders possessed 
personal networks full of structural holes, but they required trust and cooperation to exploit those opportunities.

In the entrepreneurship literature, Aldrich and Zimmer (1986) criticized other common theories such as personality, economic, population, and sociocultural, and suggested a social network theory that mimicked Burt's idea of network autonomy. They discussed network diversity and network density in the entrepreneurship process and concluded that entrepreneurs depend on network diversity to access business information and to attract customers, and they employ network density to enhance their capability for collective action. In addition, Xiao and Tsui (2007) and Burt, Hogarth, and Michaud (2000) demonstrated that structural holes are more beneficial in individualist rather than collective cultures. This could be seen as additional evidence that brokering behavior is more likely to be rewarded as far as it serves the collective goals.

This research goes a step further and incorporates Burt's idea of structural autonomy and homophily theory to draw a network framework of international entrepreneurship. Homophily theory builds the first step of the analytical framework and highlights the role of actors' type on the decision to enter an international market. Structural holes act as a mechanism that explain opportunity exploration through accessing novel information, and network closure describes how companies exploit opportunities by pooling shared resources. Framing the entrepreneurship process in a network perspective as suggested is in line with the purpose of this research, i.e. to focus on the role of the network and entrepreneurship on internationalization. As seen in Figure 4-6, each case has been inspected to determine how many actors in its network are international; the bigger the number, the more likely that the company will decide to enter a foreign market. The next step is to investigate the external network of each case using the structural holes theory. The richer the external network in terms of structural holes, the higher the probability of identifying international opportunities. Finally, the structure of the business network in which a company is performing determine the ability of the 
firm to realize the opportunities. More cohesive internal networks yield a higher capability of exploiting international opportunities.

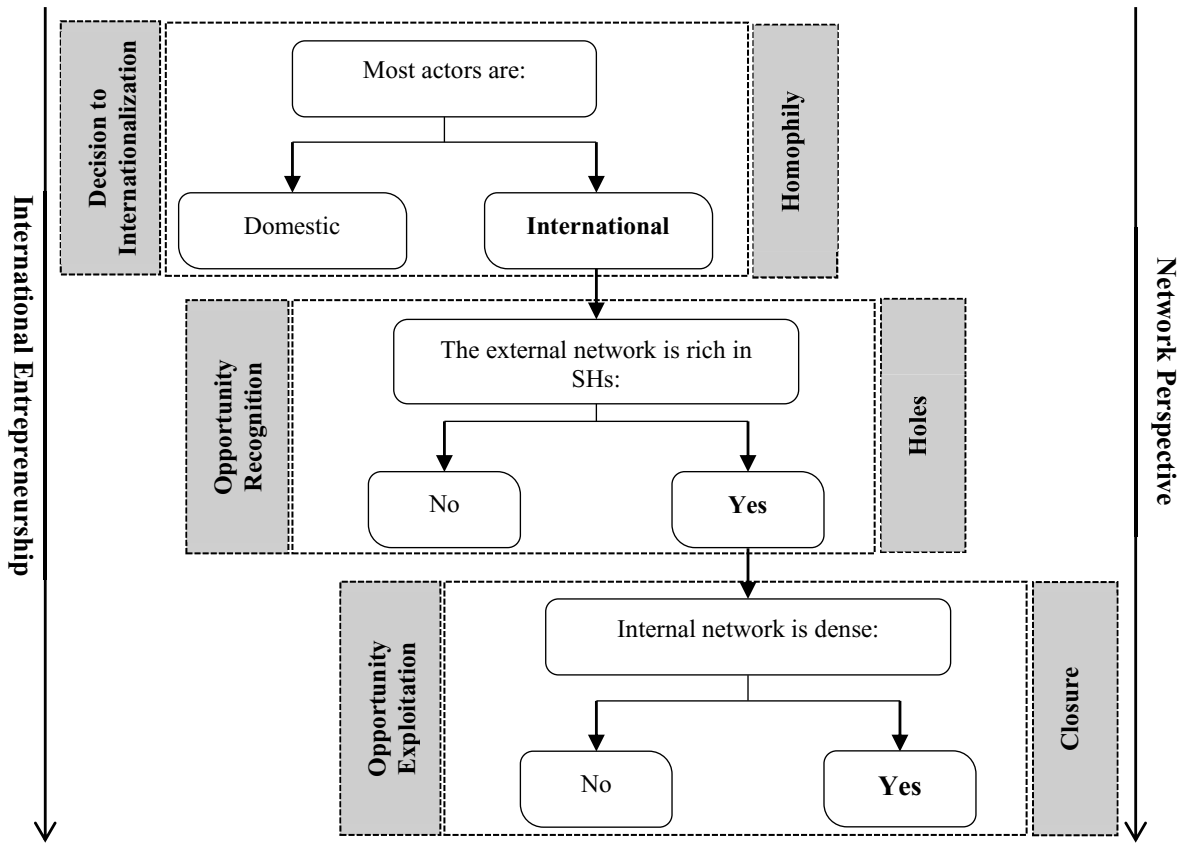

Figure 4-6: The network framework analysis of international entrepreneurship

The subsequent analysis of network autonomy is applicable to discuss the performance of both domestic and international companies, but in accordance with the purpose of this study, it is only employed to describe the international performance of entrepreneurial companies. Obviously, other studies can apply the last two steps of the framework (the structural holes and the network closure) to investigate the overall performance of companies.

\subsubsection{Case One: The Forced Entrepreneurial Company}

The forced-entrepreneurial case, the company that showed a high degree of entrepreneurial behavior despite its low orientation to entrepreneurial activity, is a small shrimp farming firm. It is located on the seashore to access proper water for farming shrimp in their natural habitat. There are many other similar companies that are located on the same coast, comprising an industrial cluster of shrimp farmers. Surprisingly, all the 
companies in the industrial cluster fully cooperate together and voluntarily share their technical knowledge, production professionals and lab equipment such as salinometers, growth meters, and sophisticated thermometers. They see their overall cooperation as contributing to a powerful team which helps them to act as a whole body.

The CEO established the company in 2007, borrowing from public finance. He earned his formal education in fishery and shrimp farming before starting the business; thus, he was completely familiar with the technical subjects of the work. However, he did not have any formal or informal education in business administration and management. Coming from the area, he truly knows the local people and the local culture, and he understands the complexity of soil and climate, which complement his technical knowledge. In addition, he receives professional advice, consulting and assistance for altering or improving his company's production equipment and administration system from other members of the cluster, especially a large professional company that acts as the informal leader of the group.

Shrimp farming is a seasonal profession with a heavy work load in the summer and a standby period in the winter. Accordingly, 6 people work as full-time employees, which increases to 50 when the seasonal workers are recruited during the summer. The employees usually have a low level of education and do not have a permanent job, or are individuals who are looking for extra income during their summer holidays; therefore, they do not enjoy adequate incentives or have the loyalty to strive for better production in terms of both quality and quantity. The advice given the company by the informal leader to resolve this problem was to include and reward employees in a way that they stay for a full season and provide more effort.

When, I started the business, I faced a big challenge. Most workers were seasonal, poor, low educated people who work in their free time and didn't see this job as a real profession. I was frustrated with those people. They didn't work well and quit when we were in the peak time. That was the time that I got very professional advice from ...... They advised me how to reward the workers by sharing a small amount of their own final production. 
The informal leader of the cluster is not a shrimp farmer like the others in the group, but rather a fairly big monopolistic fish food company that produces the best quality shrimp food using modern technologies. It also acts as an influential broker connecting the small shrimp farming companies to international buyers. The leader has a professional detailed mechanism to bridge the gap between the farming firms and their international buyers. It supplies shrimp food to the farmers and in turn asks for an informal or sometimes formal contract to sell their products through its sales department instead. The leader also supplies raw material, consultants, and new and modern equipment to improve the quality and quantity of the members' production to benefit both sides.

In reality, the members of the group are pushed by the leader to use more advanced technologies, to improve their administrative systems, and to deal with their managerial issues more effectively. Hence, the members are forced to show entrepreneurial behaviors in their production and administrative systems. This complicated behavioral mechanism between the leader and other members explains why this company has taken a forced entrepreneurial position. The brokerage role of the leader that effectively manages companies to produce suited products for international markets, ingroup trust which enables firms to pool their resources, and the leader's access to a network of international companies rich in structural holes, facilitate the internationalization process of the forced entrepreneurial company.

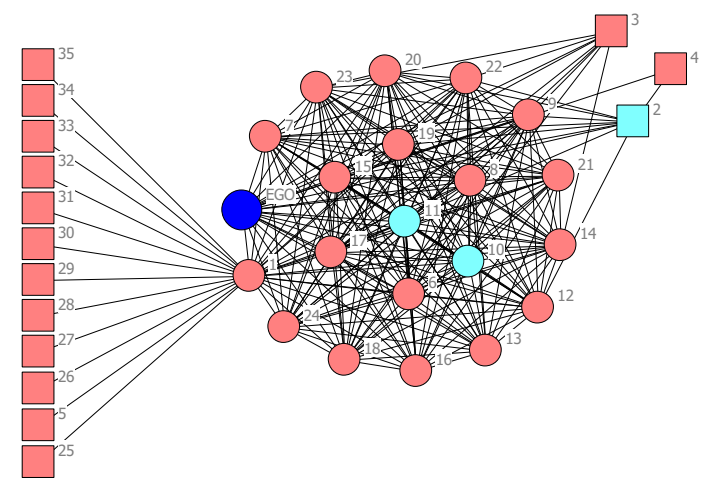

Figure 4-7: The network structure of the forced entrepreneurial company 
Mapping the network structure of the company shows that almost all the actors are international companies, which explains why the forced entrepreneurial case is an international firm. Also, it illustrates two clear-cut subgroups in the network, which are connected by the network leader (Actor Number 1 in Figure 4-7). The external network is very sparse, providing access to novel and diversified information, while the internal network is intensified enough to facilitate the sharing of technical information and the pooling of resources. This network is a proper structure to support and diffuse international activities, especially for SMEs, because: (1) other international companies, especially the leader in this case, share practical information about foreign markets such as their trends, demands, customer taste, packaging, and so on; (2) the spare external network of customers brings diversified and novel information from different markets that result in new opportunities to develop new products or reduce the risk of marketing and sales; (3) the dense internal network with suppliers and other competitors increases the trust and facilitates opportunity exploitation through sharing technical knowledge and resources; and (4) the network leader manages the cluster to act as a whole body and assist companies to enhance their production and administrative system.

Despite all the aforementioned advantages, this network structure may also impose some limitations on the actors. First, the leader in this structure is powerful and may force other smaller companies to act in a way that it advises. For instance, if a company refuses to respect the consultants or technologies that have been provided, the leader would reduce its support for selling its products at a proper price, and if this denial continues may result in expelling the company from the cluster. Second, in this structure opportunities are mostly identified by actors who occupy brokerage positions and others are less exposed to novel information; thus, the whole network features a high degree of entrepreneurship, but the individual companies only experience a narrow part of the entrepreneurial process, which results in a higher dependency on other actors for being truly entrepreneurial. This could harm the individual entrepreneurial capability of the companies in the long term. 


\subsubsection{Case Two: The Actual Entrepreneurial Company}

The actual entrepreneurial case is the biggest company among the selected firms. The owner established the company using his personal finances in 1994. He gradually added a number of different production lines and followed a product differentiation strategy to penetrate the local and national markets. The main products of the company are soft drinks, burgers, and sausages. It generates other spin-offs as well, which manufacture other types of food products such as spaghetti, potato chips, cheese puffs and so on. The company is a main player in the local market and has great control over demands and customer tastes. This company was started by an entrepreneur who did not have formal business education, but he recognized the necessity of having business education and international language training afterward and enrolled in a number of business and language programs. Unlike the forced entrepreneurial case, this firm is not located in an entrusted cluster and almost all actors around it are domestic companies, which mainly offer their products on the local or national markets. Although the company enjoys an external network with a high degree of structural holes, because most members of the external network are also domestic, it only receives diverse information about new demands or trends in the local or national markets, which encourages the company to develop its business activities within the local or national borders.

Summing up, the actual entrepreneurial company performs in a domestic industrial system that only is capable of affording information regarding the local or national markets. This kind of information exposes the company to identify opportunities within the domestic borders. It also relies on closed communication with financial institutions, suppliers, and distribution channels to make opportunity exploitation possible. It does not formally team up or form an informal cluster with those organizations, as the former cases did, but rather shapes a mutually beneficial interaction that helps to access necessary resources. As the CEO described;

Most business opportunities of our company appeared when we informally discussed our business with other people who work with us such as our main customers, the nice people in the distribution channel, and friends of our own. Despite the frequent communication that we have had with our bank 
and other partners, sometimes they don't act quickly and flexibly enough to grasp emerging opportunities. We've had some occasions that the bank or a partner offered investment but the lack of applicable ideas didn't allow us to expand.

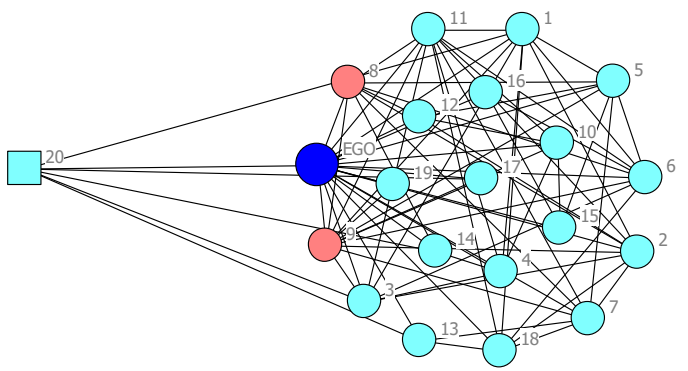

Figure 4-8: The network structure of the domestic actual entrepreneurial company

Clearly, most companies around the actual entrepreneurial firm that provide domestic information are domestic; consequently, the company has no access to information on international markets and, like other actors in its network, prefers to stay in the local market. This is in line with what is proposed by the homophily theory.

\subsubsection{Case Three: The Latent Entrepreneurial Company}

In contrast to the first two cases, the latent entrepreneurial company was started by a young, educated and very ambitious person who had the desire to create one of the most innovative and pioneering companies in the industry. The company produces pizza and a few types of pre-cooked foods. Relying on a long-lasting process of research and communication and with attention to its limited budget, the company selected the most optimized state-of-the art production equipment. The number of employees at this fiveyear old company is 16 , and all were recruited through a professional process of employment carried out by the CEO himself.

The process of the company start-up is well matched with what has usually been presented as the entrepreneurial process in formal textbooks. The person, with a high level of formal training in food production and with more than seven years of experience working in the industry, discovered an unsatisfied demand for pre-cooked pizza in the local market. To answer the identified opportunity, he investigated a number of pre- 
cooked pizza production systems around the globe and selected the best one in accordance with his budget. To meet the required human resources, he interviewed and recruited employees using a detailed and professional approach, and designed the compensation system in a way that rewards those who bring forward new business ideas or assist the company to advertise and sell the products in more creative ways.

I am monitoring the tiniest details of the business and try to keep the innovative climate alive. My employees offer many ideas especially during the lunch time when we gathered and discussed the business matters. Many ideas seemed nice but the lack of strong financial cash or credit did not allow them to be realized.

On the whole, the CEO established an entrepreneurial culture that should work, but because of some limitations, especially financial constraints, the output in terms of finished innovative products, new ventures or spin-offs, or modification plans was less than expected.

Because the company is rather a new one in the industry, the members of its business network are mostly people or companies who had done business with the founder before. Those companies helped the founder to produce, market, and sell his products in a more efficient way. They also yielded diverse information that created novel ideas when incorporated with the founder's previous experience. Despite the important role of the members in providing information and opportunity exploration, their presence in exploiting the opportunities is not significant because they are not bounded enough to act as a team to pool resources in a way that facilitates opportunity exploitation.

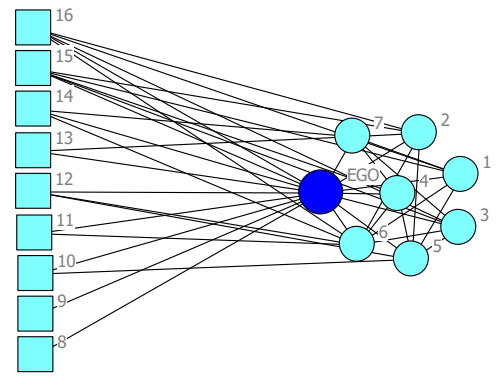

Figure 4-9: The network structure of the latent entrepreneurial company 
As in the previous case, this company is not exposed to the necessary information on foreign markets. Having no information about international markets increases the risk of new entry and encourages the company to remain in the local market.

\subsubsection{Case Four: The Non-Entrepreneurial Company}

A young person without previous business experience or a formal business education established this aviculture business in 2009. The company is a family business that supports two families, and it is mainly financed by public loans. The CEO just passed 72 hours of a free entrepreneurship course and prepared a brief business plan for its start-up. He works with his father to manage the business and they rely heavily on their personal networks to buy suitable raw material and sell their finished products. The major product of the company is live chickens, which are sold to abattoirs. The abattoirs process live chickens to produce fresh or frozen chicken meat, chicken nuggets and sometimes chicken schnitzels.

Eight people work in the poultry house, almost all are whom are Afghani or Pakistani immigrants experienced in chicken farming. The domestic market of chicken products is big enough to provide needed opportunities for starting and developing such companies; thus the government helps people to run and expand the aviculture businesses around the country. There are a number of public or nonprofit organizations which procure free consultants as well as financial and technical aids for individuals who want to start and expand such businesses. Despite the financial and technical aids that assist companies, a number of barriers also exist that limit the success of such firms. Monopolist buyers who possess a high level of bargaining power and purchase companies' products on their enforced conditions are one of the boldest challenges in the industry. These monopolistic buyers are the middlemen who work with abattoirs, have very strong bargaining power and easily drive the market.

Moreover, the company also has weak bargaining power on the supply side. Their suppliers are mainly public organizations or large importers who implement inflexible procedures that cause massive challenges to the firm. The suppliers are mainly divided in 
two main types: public and private importers. The former proposes lower prices, but the company must pay the money in advance and agree to a forced delivery time. The public suppliers usually do not respect their agreed upon timelines and the company must wait for a long time to receive its supplies. The shiftiness of the public suppliers causes many problems for the company, and forces it to deal with the private suppliers who offer higher prices.

The CEO does not have any experience in marketing, business development and entrepreneurial strategic planning. He mainly consults with other people who are working in the same business. Therefore, the company mainly follows a traditional shopkeeper management style with the primary goal of generating enough income to cover the business operation and support the families. Similar to the forced entrepreneurial case, a cooperative climate dominates and all the companies help each other to enhance the production quality and quantity. In contrast to the informal leader in that case who worked to increase the trust among the members, the monopolistic buyers in this case interfere to reduce the trust because they are afraid of diminishing their bargaining power if the companies act collectively.

In our latest harvest, the buyer offered me a lower price than the market. I decided to sell my chickens personally. Finding a good customer was so difficult. The buyer threatens other middlemen to don't buy from me and asked my colleagues to keep their distance. I just sold one truck and was forced to return back again to the buyer and accept a lower price than what it was offered at the first place.

The non-entrepreneurial company does not have access to a wide range of external people or companies. Furthermore, those few external people or companies are fully connected, which resulted the flow of repetitive information in the external network; thereby, it suffers from a lack of new and innovative ideas to expand the business. The internal structure of the network holds a desired level of density that facilitates the sharing of technical knowledge and resources, but it is extremely influenced by the middlemen's interference, which diminish its efficiency. 


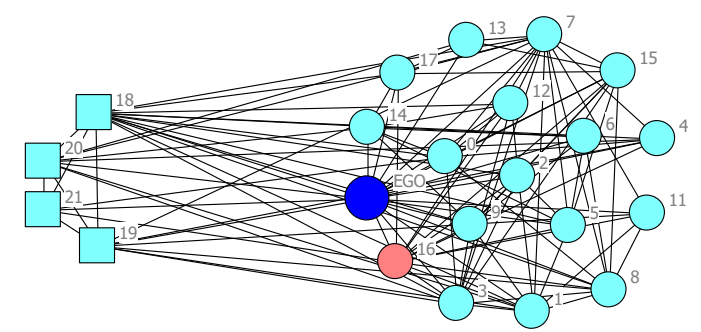

Figure 4-10: The network structure of the nonentrepreneurial company

The network structure of this company again confirms the effect of other actors' attributes on the internationalization process. Almost all the actors in this network are domestic, except for a company that imports chicken feed concentrate from the Netherlands.

\subsubsection{Contrast Case: The Internationalized Actual Entrepreneurial Company}

The first actual entrepreneurial case was a domestic company. Analyzing that case and comparing it with the forced entrepreneurial company was informative, but having an international actual entrepreneurial company as a contrast case could reveal new insights regarding why the actual entrepreneurial companies displayed a lower degree of internationalization than the forced entrepreneurial firms.

This company was established by a visionary entrepreneur in 1995 as a small firm performing in the domestic market. At first, the entrepreneur performed all necessary business activities alone and focused on a very small part of the local market. He did not possess a formal business or management degree, but had many years of experience and enjoyed a great network of communication in farming and selling fresh fruit. Gradually, the business was grown and different sub-units were added. A transportation unit was founded and a cold storage facility with a capacity of 2500 tons was purchased to cover markets that were further away and to supply all-season fruit. The bank had a bold role in financing the later developments of the business, but the entrepreneur himself provided almost all the necessary investments for start-up and primary developments. 
The entrepreneur found an international customer in a neighboring country through one of his friends who worked in the food and fruit transportation segment. He realized that the profit margins in international markets are higher and the competition is lower, but they needed more sophisticated processing, storage, and transportation; thus, he focused on the international markets more and used his network of relationships to find more customers.

Actually, those markets were more attractive. Customers were more professional and their higher profit margins was so tempting. I decided to expand the business in this direction because it gave me a better feeling and higher profit. Some of my colleagues were in the international markets before and had better communication there; but as you may know, there is no free thing in business. They expected me to give them something instead, and I dealt with them to access good communication in those markets.

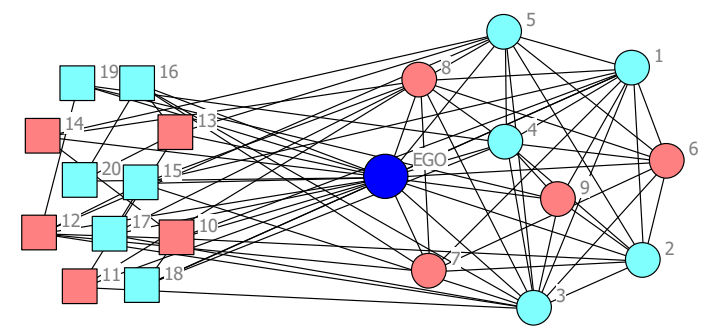

Figure 4-11: The network structure of the international actual entrepreneurial firm

However, most companies in this network were domestic, a number of international firms also existed in both the internal and external structures which open a new gate to international business. The internal actors helped the company to enter the foreign markets, but, both international customers and international suppliers and competitors played a role in its subsequent international activities.

\subsubsection{Cross-Case Analysis}

Discussing the network structure was the bottom line of the interviews and the qualitative analysis of the cases; accordingly, in this section, the network structure of the cases will 
be discussed and compared in detail. To follow the logic of the literature-driven analytical framework, three bottlenecks were determined as the indices of comparison: the ratio of international actors to all, the structural holes analysis of the external networks, and the cohesion analysis of the internal groups. In accordance with the analytical framework, this analysis was performed in three distinctive steps, and in each step one dimension was discussed. First, the international involvement was explained based on the ratio of international actors in the networks. Second, an analysis of structural holes of external actors was performed. Third, internal actors were analyzed in terms of the network cohesion. The last two steps only performed for the international cases to inspect the influence of network structure on their international performance. Therefore, the international involvement of all the five cases was discussed, but just two of them - the forced entrepreneurial and the international actual entrepreneurial case - received further analysis on structural holes and cohesion.

As the analytical framework assumed, having more international companies around fundamentally influences the international involvement of a company. Table 4-10 shows the international degree of all the investigated networks. The two international cases clearly include more international actors in their networks. For instance, the forced entrepreneurial company enjoyed the highest number of international actors in its network, followed by the international actual entrepreneurial case. In contrast, all three domestic companies demonstrated an international degree of 10 percent or less. These results are in line with the network homophily idea and Johanson and Mattson's theory in that they explain how companies are influenced by actors' similarities in their decision to enter an international market.

While both the forced entrepreneurial and the international actual entrepreneurial cases are operating in international markets, their level of international performance is significantly different. While the forced entrepreneurial firm obtained more than 80 percent of its final sales from the international markets, the international actual entrepreneurial case only received 30 percent of its total income from abroad. Also, the forced entrepreneurial firm marketed its products in about 10 foreign markets, compared to the 3 international markets of the actual entrepreneurial company. To find out why the 
forced entrepreneurial case shows a higher scale and scope of internationalization, looking at the internal and external structure of its network is instructive.

Table 4-10: The network description of the selected cases

\begin{tabular}{|c|c|c|c|c|c|}
\hline & Case 1 & Case 2 & Case 3 & Case 4 & Contrast Case \\
\hline $\begin{array}{l}\text { Company } \\
\text { type }\end{array}$ & $\begin{array}{c}\text { Forced } \\
\text { Entrepreneurial }\end{array}$ & $\begin{array}{c}\text { Actual } \\
\text { Entrepreneurial }\end{array}$ & $\begin{array}{c}\text { Latent } \\
\text { Entrepreneurial }\end{array}$ & $\begin{array}{c}\text { Non- } \\
\text { Entrepreneurial }\end{array}$ & $\begin{array}{c}\text { Actual } \\
\text { Entrepreneurial }\end{array}$ \\
\hline $\begin{array}{l}\text { Network } \\
\text { Structure }\end{array}$ & 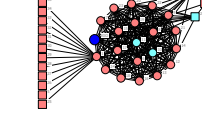 & & 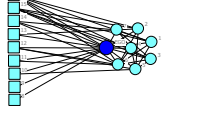 & 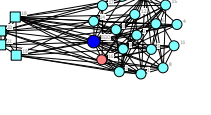 & 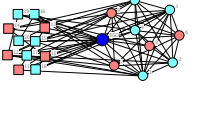 \\
\hline I-Degree & $91.43 \%$ & $10 \%$ & $0 \%$ & $4.76 \%$ & $45 \%$ \\
\hline Status & International & Domestic & Domestic & Domestic & International \\
\hline I-Scale & $80 \%$ & 0 & 0 & 0 & $30 \%$ \\
\hline I-Scope & 10 & 0 & 0 & 0 & 3 \\
\hline
\end{tabular}

Note: I-Degree (the internationalization degree of a network), I-Scale (the scale of internationalization), and I-Scope (the scope of internationalization).

For the sake of the analysis, in this research an internal network includes the suppliers and competitors, while an external network contains the customers of a focal company. A primary analysis was conducted to identify the most central actor as a basis of dividing the overall structure into internal and external networks. As Table 4-11 shows, the most centralized actor in the business network of the actual entrepreneurial company was the ego company (degree $=1.000$, closeness $=1.000$, betweenness $=35.495$ ). This is not true in the case of the forced entrepreneurial firm. In that case, the most centralized actor was the informal leader of the network (degree=.914, closeness=.921, betweenness $=57.479$ ) and the ego received a lower degree of centralization. Therefore, the reference point for dividing the network in this case was the informal leader, not the ego. In addition, looking more precisely at that network shows that all the members are connected to the customers through the leader.

Table 4-11: The network position analysis of the ego and the powerful actors

\begin{tabular}{llll}
\hline & \multicolumn{1}{c}{$\begin{array}{c}\text { The Forced } \\
\text { Entrepreneurial Company }\end{array}$} & $\begin{array}{c}\text { The Contrast } \\
\text { Case }\end{array}$ \\
\hline \multirow{2}{*}{ Degree (normalized) } & Most Centralized & .914 & 1.000 \\
\cline { 2 - 4 } & Ego & .675 & 1.000 \\
\hline \multirow{2}{*}{ Freeman Closeness } & Most Centralized & .921 & 1.000 \\
\cline { 2 - 4 } & Ego & .745 & 1.000 \\
\hline \multirow{2}{*}{ Freeman Betweenness } & Most Centralized & 57.479 & 35.495 \\
\cline { 2 - 4 } & Ego & 5.804 & 35.495 \\
\hline
\end{tabular}


Table 4-10 summarizes the cohesion and structural hole analysis of the internal and external networks. The overall and the ego density of the internal group of the forced entrepreneurial (average degree $=10.000$, overall density $=1.000$, ego density $=1.00$ ) was higher than the actual entrepreneurial company (average degree $=3.700$, overall density=.822, ego density=.772), which means a higher potential of the forced entrepreneurial company to exploit the entrepreneurial opportunities.

Also, the external network of the forced entrepreneurial firm reveals a higher degree of structural holes. It shows a larger effect size (12.000 vs. 9.182) and a lower constraint (.083 vs. .250) that signify a better efficiency (1.000 vs. .835) in terms of the structural hole analysis. Consequently, the forced entrepreneurial company were placed in a better position to identify opportunities. Of course, the opportunities are identified by the leader and then are shared with other actors in the network. But as was explained before, there is a mutual benefit for both the leader and the other actors in identifying, sharing, and exploiting opportunities; thus, all information and resources are freely being shared and the network acts professionally as an entrepreneurial cluster.

Table 4-12: The network analysis of the selected cases

\begin{tabular}{|c|c|c|c|c|}
\hline & \multicolumn{2}{|c|}{ Forced Entrepreneurial Company } & \multicolumn{2}{|c|}{ Actual entrepreneurial Company } \\
\hline & Internal & External & Internal & External \\
\hline Number of Ties & 210 & 13 & 37 & 21 \\
\hline $\begin{array}{l}\text { Average } \\
\text { Degree }\end{array}$ & 10.000 & .812 & 3.700 & 1.750 \\
\hline $\begin{array}{l}\text { Overall } \\
\text { Density }\end{array}$ & 1.000 & .108 & .822 & .318 \\
\hline Ego Density & 1.000 & .000 & .778 & .182 \\
\hline Effect size-SH & 1.000 & 12.000 & 2.788 & 9.182 \\
\hline Efficiency-SH & .050 & 1.000 & .309 & .835 \\
\hline Constraint-SH & .190 & .083 & .388 & .250 \\
\hline Ln Constraint & -1.660 & -2.485 & -.946 & -1.388 \\
\hline $\begin{array}{l}\text { Ego } \\
\text { Betweenness }\end{array}$ & .000 & 132.000 & 3.452 & 81.000 \\
\hline
\end{tabular}


This structure also may impose some disadvantages that were discussed before. The leader poses the most powerful position (ego betweenness of 132.000), which can control all the flows of information. But the leader needs the whole body of companies to pool their resources and technical knowledge to efficiently realize the opportunities. In such a dense network, the leader's opportunistic behavior is easily detected and confined to other actors. Consequently, opportunistic behavior is very risky and the leader's centralization power is partly canceled out by the internal trust in the network.

Despite the less powerful individual position of the forced entrepreneurial compared to the actual entrepreneurial firm, its overall network structure was better fitted to identify and realize international opportunities. Additionally, the internal trust counterbalanced the power of the leader in the forced entrepreneurial network, reduced the risk of opportunistic behavior and increased the overall network efficiency. All in all, and in line with Burt's network autonomy idea, all the members of a network (the forced entrepreneurial company in this study) benefited from being in a network that effectively supported the exploration and exploitation of opportunity. Moreover, if the supportive network contained more international actors, the probability of the opportunities to be international will increase, and this is the place where the network perspective and international entrepreneurship meet. 


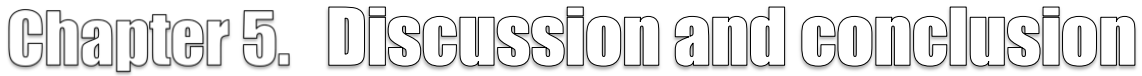

This final chapter of the research discusses the findings, remarks on the literature to corroborate or explain the results, and concludes with brief but clear answers to the research questions. The process of discussion corresponds to the former chapter, and begins with debating the measurements, followed by reasoning about profiling the entrepreneurial firms, testing the research hypotheses, and finally explaining the role played by business networks on the internationalization of SMEs.

\subsection{Discussion}

\subsubsection{EO and CE: The Measurement Characteristics}

Valid and reliable measurements that are properly defined and specified in terms of the measurement model and construct dimensionality are the cornerstone of a quantitative research study. The first thing that should be considered in measurement assessment is the consistency of a measurement model with its conceptual definition (George \& Marino, 2011). This consistency is necessary, but not sufficient, for determining the measurement model of a construct (Law et al., 1998). If a measurement model is not correctly specified, it may harm both the construct validity and statistical analysis. Misspecified measurement model may causes the inflation of structural parameters by up to $429 \%$ in general (MacKenzie et al., 2005), and by over 240\% in EO models (George, 2011). Another important argument worth mentioning here is that surrounding construct dimensionality 
(a detailed literature review on the dimensionality of EO and CE was presented in Chapter Two, Sections Five and Six). Construct dimensionality has been the subject of conflicts and severe debates in the firm-level entrepreneurship literature.

Unfortunately, there are a number of entrepreneurship studies that have confused the measurement model and construct dimensionality, and which have interchanged unidimensionality with reflective specification and multidimensionality with formative construction (e.g. Dess et al., 2011; Kreiser et al., 2012; Rauch et al., 2009; Rigtering et al., 2013; Wales et al., 2011). Actually, the measurement model and construct dimensionality are two different steps of measurement development, and implementing them interchangeably may harm the overall credibility of a measurement. The first deals with the specification of observational items or of dimensions (lower-level constructs) to a (higher-level) construct, while the second deals with the order of those items and dimensions. Measurement models are generally divided in two different categories, reflective and formative. The causality in a reflective model flows from a construct to its dimensions, and from the dimensions to the construct in a formative model (George $\&$ Marino, 2011). In respect to their dimensionality, both reflective and formative measurement models can be classified as first-order or higher-order constructs (Covin \& Wales, 2012). Unidimensional constructs are defined as the first-order models, and include a bundle of observable variables that derive a latent variable, while multidimensional constructs are defined as higher-order constructions that incorporate a number of lower-level latent variables (sometimes called dimensions) into a higher-level variable. In other words;

Whereas the items used to measure a unidimensional construct are all observable variables, the dimensions of a multidimensional construct usually are unobservable latent variables" (Law et al., 1998, p. 743).

In summary, unidimensional and multidimensional constructs can be specified as reflective or formative models. There are some methodologists who have applied different names to the reflective and formative multidimensional constructs to avoid the confusion. For instance, Edwards (2001) labeled the reflective multidimensional model as superordinate and the formative multidimensional as aggregate construct. Following this 
approach to avoid confusion, this research separates the measurement model and construct dimensionality by referring to the first as how items or dimensions are specified to a construct, and the second as the number of layers or orders that define a construct.

The measurement models of EO and CE are elaborated on in Chapter Two (see Sections Five and Six). The prior research of firm-level entrepreneurship advised that choosing the appropriate measurement model of a construct is largely dependent on the theoretical perspective and the purpose of a study (Covin et al., 2006; Covin \& Wales, 2012). In reference to the literature and to respect the purpose of this study, which views $\mathrm{EO}$ and $\mathrm{CE}$ as the individual dimensions of a higher order construct of firm-level entrepreneurship, EO and CE are modeled as reflective measurements. In fact, this study was inclined to investigate the mixed effect of $\mathrm{EO}$ and $\mathrm{CE}$ on the internationalization of the SME, and the individual effect of each construct or their dimensions was not the concern; thus, reflective models are better adapted with the research purpose. Moreover, the empirical results revealed a high correlation between the individual dimensions of EO (ranging from .488 to .677 , all significant at .01 percent of p-value) and CE (even better than EO dimensions starting from .761 to .843, all showing a p-value less than .01), which corroborate the conceptual discussion and support the reflective measurement models of the constructs.

Construct dimensionality has resulted in fewer contradictions than the measurement model, and a partial agreement exists on the multidimensionality of both EO and $\mathrm{CE}$, but the number of dimensions is still strongly debated. With respect to their original and most popular operationalization, EO and CE are defined as three-dimensional constructs. Furthermore, the results of an advanced SEM technique, implemented in this study to perform a statistical difference test of unidimensional and multidimensional models (Table 4-2), were in agreement with the current CFA analysis of EO dimensionality in the literature (e.g. Kreiser et al., 2002). The SEM analysis showed a multidimensional conceptualization as a better fitted model with both measurements of EO and CE. A deeper look at the calculations reveals EO as a better fitted construct than CE, especially when they are modeled as multidimensional reflective measurements. Maybe the lower number of items that provides a more parsimonious measurement scale, 
or the accumulated knowledge of its measurement validity resulting from different empirical contexts, could be the reasons for the better specification of EO. Summing up, the empirical analysis reaffirms and credits the proposed conceptualizations of EO and $\mathrm{CE}$ as reflective three-dimensional constructs, which represent the orientation and activities of firm-level entrepreneurship.

To check on the individual items and assess the validity and reliability of the measurements, a CFA technique was conducted, which propounded interesting insights that are worth additional discussion. To achieve a fitted model that usually acts as the basis of measurement validity and reliability, a number of items were eliminated (Table 4-1 shows the final validity and reliability figures). An item of innovativeness (EOI3) was removed because of its small factor loading, showing this item does not truly reflect the innovativeness. Removing this item does not harm the whole construct of innovativeness because it had indicated a high redundancy with another item (IEO2). Deleting an item from EO, especially the dimension of innovativeness, is not very unusual, especially in international studies (Runyan et al., 2012). There are several studies that have applied an EO version of 8 items (e.g. Baker \& Sinkula, 2009; Hansen et al., 2011; Kreiser et al., 2002) or even fewer (e.g. Zahra \& Garvis, 2000). In the same vein, an item was eliminated from venturing (CEV6); That item had also displayed some kind of redundancy with other items of venturing. Among all, environmental hostility had the most inconsistent measurement, and several items were deleted to obtain the adequate validity and reliability. Removing several questions from environmental hostility seems rational in the context of the research, because most investigated SMEs relied more on cooperation than competition to improve their overall performance. Consequently, the severe competition on price and quality is not relevant. Actually, a majority of the studied companies supply their raw material, produce, and sell their products in a cooperative manner in which quality and price are determined based on collective decisions. Also, public policies are not so influential because the companies mainly depend on synergic cooperation rather than governmental support. The only role that plays by the public institutions is their endeavors to improve the cooperation and resolve the conflicts. 


\subsubsection{Profiling Companies: EO versus $C E$}

As has been quoted many times in this research, entrepreneurial orientation and corporate entrepreneurship are not alternative measurements which can be used interchangeably to measure a complicated phenomenon such as firm-level entrepreneurship (for a detailed discussion on the topic, see Chapter Two, Section Seven). Honestly, researchers who apply just one of these measurements are only able to discuss entrepreneurship orientation or entrepreneurship actions, not the whole phenomenon of firm-level entrepreneurship. Firm-level entrepreneurship is a higher order phenomenon that incorporates both the attitudinal and behavioral dimensions; thus, relying on one part delivers a blind picture. To bridge this gap, this research has combined EO and CE in the higher order variable of firm-level entrepreneurship. Unfortunately, the existing endeavors of synthesizing these constructs contain severe problems that seriously damage their usability (Chapter Two, Section Seven counts and explains those problems).

A profile model of firm-level entrepreneurship that avoids the current critics of the integrated measurements, classifying firms in the four different groups of nonentrepreneurial, latent entrepreneurial, forced entrepreneurial, and actual entrepreneurial companies, is presented as a more comprehensive measurement of the phenomenon in this research. Cluster analysis, corroborated with conceptual discussion, revealed four different groups in the investigated SMEs (Table 4-4). The match of the conceptual discussion and the empirical findings supports profiling companies in terms of EO and CE as a suitable method of measuring firm-level entrepreneurship.

In reference to the theoretical discussion, firms can be classified into four different groups considering their entrepreneurial orientation and entrepreneurial action. A company could be graded high or low in both EO and CE, or low in one and high in another. The cluster analysis exactly replicated this logic and divided companies into four different groups; the first two clusters showed minus or positive centroids in both EO and $\mathrm{CE}$, while the last two revealed a minus centroid in one and a positive centroid in another. Looking at the other characteristics of the clusters displayed more interesting insights. The latent entrepreneurial companies, as was expected, are the youngest firms among all. Their age could be a potential explanation for having no entrepreneurial action in spite of their 
intensive orientation to apply entrepreneurial and innovative strategies. The forced entrepreneurial companies, in contrast, are the oldest and build a solid foundation in their markets. They act in cooperative groups under the informal leadership of a bigger company, which advises them to implement new technologies, to modify their current organizational structures, and to build a better foundation for developing venturing businesses. The non-entrepreneurial firms are micro-enterprises that usually start with just a person or a family, and they do not aim to grow beyond a specific level. The owner of those companies is not interested on innovative ideas or entrepreneurial strategies and tries to avoid risky decisions. The actual entrepreneurs, in contrast, are those who start and run their businesses as a way to fulfill their ambitions. These people usually start a latent entrepreneurial business, which later becomes an actual entrepreneurial company when they obtain enough experience and necessary resources. The findings confirm this, and reveal the actual entrepreneurial as the older companies rather than the latent entrepreneurial firms.

In summary, the clustering results certify the theoretical discussion, and confirm the profile model as a proper way to classify companies in terms of their entrepreneurial statutes, at least in the context of this research. Unlike the EO or CE, that just focus on one component of firm-level entrepreneurship, this model incorporates both attitudinal and behavioral elements of the phenomenon and covers both the exploration and exploitation steps of the entrepreneurship process.

\subsubsection{Entrepreneurship and Internationalization}

A quick glance at Table 4-4, which summarizes the characteristics of profiling clusters, shows the forced entrepreneurial companies as the highest and fastest internationalized group, followed by the actual entrepreneurial firms. This is not perfectly in agreement with what the literature predicts (the relevant literature was reviewed and summarized in Chapter two, Section Eight). Clearly, relying only on descriptive analysis is not enough to infer such a general conclusion, and a more sophisticated inferential analysis is needed to correctly and thoroughly discuss the subject. Generally, to perform an advanced hierarchical regression involving categorical variables, a proper coding method that 
captures an optimized picture of data and provides a rich post-hoc analysis is highly advised. With attention to these considerations and the directed hypotheses of the research, the contrast coding has been applied as a suitable scheme in this research (Table 4-5).

The regression analysis confirms the results of the descriptive analysis, showing the forced entrepreneurial cluster as the highest internationalized group in terms of international involvement, international scale, international scope, and speed of internationalization (for more detail, see Tables 4-6, 4-7, and 4-8). The only exception is when the environment becomes very hostile, in which the actual entrepreneurial companies exceed the forced entrepreneurial and display better internationalization. That the actual entrepreneurial firms exhibit the highest degree of international scale, scope, and speed of internationalization in hostile environments is supported by the literature. The contingency theory, configurational approach and a large part of the empirical studies suggest entrepreneurship as a proper strategy in a hostile environment (e.g. Crick \& Jones, 2000; Ibeh, 2003; Ibeh \& Young, 2001; Robertson \& Chetty, 2000). Shoham et al. (2002) advised companies to choose strategies that fit with their types if they want to achieve better international performance.

The surprising part of the findings is related to the internationalization activities of the forced entrepreneurial companies. While the literature predicts better internationalization, especially with regard to international performance for the actual entrepreneurial firms, which enjoy a higher entrepreneurial status (e.g. Chandra et al., 2009; Crick \& Jones, 2000; Francis \& Collins-Dodd, 2000; Hagen et al., 2012; Ibeh, 2003; Knight, 2001; Knight \& Cavusgil, 2004; Lan \& Wu, 2010; McGuinness \& Little, 1981; Ripolles et al., 2007; Yiu et al., 2007; Zahra \& Garvis, 2000; Zhou, 2007), the empirical results reveal the forced entrepreneurial profile as the most successful type. Therefore, the first question that came to mind when facing with these findings was: Why the forced entrepreneurial firms? What is their essential capability that helps them to exceed all the other types? To answer these questions, it is necessary to check on their characteristics and deeply delve into each dimension of their internationalization. As was implied before, the forced entrepreneurial group is the oldest cluster among all. Being older means having more experience and accessing a better basis of knowledge and resources for 
internationalization. In their study on international growth and scale, Autio et al. (2000) found that the international performance of entrepreneurial companies improves as they grow older. Another reason that seems more relevant than their age is the way that the forced entrepreneurial SMEs. The force entrepreneurial SMEs in this research act as a collective body which follows a pure cooperative strategy to produce and sell their products and services. This collaboration may force a few restrictions that could limit their innovative and entrepreneurial potential, but it yields a number of advantages that are required for performing successfully in international markets. This network of cooperation enables the forced entrepreneurial companies to procure required knowledge and resources. Limited access to knowledge and resources has been mentioned as a fundamental impediment of SMEs' internationalization (Leonidou, 2004; Leonidou et al., 2007). This network also compels companies to implement modern technologies and modify their organizational structure to cope with changing business environments. Therefore, the collective action of the forced entrepreneurial companies is the best explanation for their higher level of internationalization, but how? Thus, another question that needs a correct answer and seems crucial to finalize this study is: How can business networks affect the internationalization of investigated companies?

\subsubsection{Role of Business Networks}

To study how business networks could influence the internationalization of different profiles, five companies were selected: one firm of each classification and a contrast case from the actual entrepreneurial category. An analytical framework was developed based on the current network theories, which presents the process of international entrepreneurship in a network perspective (Figure 4-6). All the cases received a withincase analysis, and an overall cross-case comparison was performed with respect to the analytical framework.

The results showed the fundamental aspects of a network structure that may affect the internationalization of entrepreneurial companies. Companies that are surrounded by more international actors are more likely to be involved in internationalization activities. Among all the cases, only the forced entrepreneurial and the contrast cases were 
positioned in the international networks so that they entered international markets (for more information, see Table 4-10). The other cases, which were mostly surrounded by domestic enterprises, displayed no international involvement at all. These findings are in accordance with the homophily theory, which predicts companies are attracted to other firms that are similar to them, or that companies become similar to other firms that they are surrounded by. Actually, the presence of more international actors in a business network facilitates acquiring foreign knowledge that is of vital importance to successfully start and manage an international venture (Bell, 1995; Yu et al., 2011). Although having international companies around may help to obtain required knowledge, there are other features that determine the efficiency of a network structure. Speaking from the entrepreneurship perspective, some networks provide a better foundation to identify and exploit entrepreneurial opportunities. The two popular network theories of structural holes and network closure were incorporated to determine the efficiency of a network structure in the exploration and exploitation of entrepreneurial opportunities.

The structural holes theory (Section 4.3.2) explains unconnected actors in a network structure as a basis to obtain diverse and non-redundant information. Having more unconnected actors helps a focal company to identify better opportunities in terms of both quantity and quality. Despite all the advantages, structural holes may cause some sort of distrust, which drives companies to not share their technical knowledge or pool their complementary resources with each other. Network closure (Section 4.3.3) fills this gap, and suggests a dense structure as a way to increase trust among members and convince them to share their technical knowledge and pool their complementary resources. Network closure concentrates more on opportunity exploitation through sharing complementary knowledge and resources. Both theories have their own advantages, but neither covers the whole process of entrepreneurship alone. It seems a proper combination of these theories is necessary to deliver a network perspective of the entrepreneurship process. Fortunately, there is a network explanation of entrepreneurship in the literature that incorporates both in a very persuasive way (Figure 4-5 shows a schematic picture of that idea). Following this explanation, the two cases that showed some kind of internationalization were selected and compared in terms of the structural holes and 
network closure in their external and internal structures (Table 4-12 displays the final analysis of the external and the internal structures of the forced entrepreneurial and contrast cases).

Looking at the analytical figures shows the spare external network of the forced entrepreneurial company as a source to identify attractive opportunities. Moreover, the dense internal network of the firm causes a high level of trust that facilitates sharing technical knowledge and resources to exploit opportunities. Actually, this company is in a position to receive diverse information from the external actors and complementary resources and technical knowledge from the internal members. Therefore, it can identify and exploit opportunities faster and in a more efficient way. The contrast case, an international actual entrepreneurial firm, has a worse status in regard to structural holes of the external and the density of the internal structure. It seems that combining the homophily theory, which explains the presence of international members, and the network theory of entrepreneurship, which explains the efficiency of an entrepreneurial network, has good potential to explain the internationalization of entrepreneurial businesses. Having more international actors around facilitates accessing relevant information about international markets, and holding an efficient network structure helps to identify and realize international opportunities more effectively.

Another important point worth mentioning here is the source of the entrepreneurial orientation of the forced entrepreneurial company. It is true that it does not show a high level of orientation, but this statement is quite arbitrary and depends on the level of analysis. By extending the level of analysis from the company to its network, EO can be traced to another actor in the network. The informal leader who brokered the external and the internal structure of the network possesses a high degree of entrepreneurial orientation, which is transferred to the whole network through a specific business dynamism. In fact, looking through network glasses depicts the whole network as an actual entrepreneurial cluster, in which attitudinal and behavioral components may not be limited to the formal borders of a given firm. 


\subsection{Conclusions}

There is a huge body of research focusing on firm-level entrepreneurship and its relationship with corporate performance. This study aims the beneficial influence of firmlevel entrepreneurship on the internationalization of smaller enterprises. The first dilemma, which emerged from the beginning, was the proper conceptualization and operationalization of firm-level entrepreneurship. Different studies have applied different measurements, viewed them as better alternatives, and criticized others. A closer look through this research has disclosed a profile model that incorporates EO and CE as a better representative of the whole construct. Unlike other integrated measurements, this model does not suffer from nomological deficiency or overall validity problems. It also does not break down the current well-known constructs to unpopular new ones. The cluster analysis was truly matched with the profile model, and classified the investigated companies into the four groups of non-entrepreneurial, forced entrepreneurial, latent entrepreneurial, and actual entrepreneurial. Furthermore, the empirical analysis of measurement validity corroborated the conceptual discussion, and suggested a reflective three-dimensional measurement as a better fitted model for both the constructs of EO and CE. On the whole, the empirical findings were in agreement with the conceptual and theoretical discussions, which suppose EO and $\mathrm{CE}$ as reflective three-dimensional constructs that jointly determine the firm-level entrepreneurship status of a company on the basis of a profile measurement model.

The survey part of the research was totally surprising: in contrast with what the literature suggests, the empirical findings revealed the forced entrepreneurial companies as the most internationalized enterprises, except when the environment becomes very hostile. Therefore, the answer to the first and second research questions is as follows;

Having some kind of entrepreneurship in terms of orientation or behavior helps companies to achieve better internationalization (all kinds of entrepreneurial companies revealed better internationalization than the non-entrepreneurial firms), but except in a very hostile environment, the whole construct of firm-level entrepreneurship as defined and modeled in this research could not explain the difference between the 
internationalization of different types of entrepreneurial profiles. Even though the actual entrepreneurial companies were expected to show the highest level of internationalization, the forced entrepreneurial firms performed better in reality.

The potential explanation for this surprising result lies in the characteristics, and more importantly in the way that the forced entrepreneurial companies perform their daily business. In terms of characteristics, the forced entrepreneurial firms are the oldest. The time a company has been operational has been considered to be an influential factor in international business that helps companies to build a reliable financial foundation and find a firm position in their markets. Another explanation that seems a better fit with the way that the forced entrepreneurial companies acted in this research is collaboration, collective action, or in a more professional expression, business network structure. The forced entrepreneurial companies act as a whole under a solid and uniform network structure that enables them to discover and exploit opportunities faster and more efficiently. An engaging question for this research, and one which provided interest in another step, was: How does a business network facilitate the internationalization of entrepreneurial companies?

To answer this question, a case study was applied. Four cases were selected, one from each category. Because the target group of the study was the actual entrepreneurial cluster and the elected actual entrepreneurial case was a domestic business, another case (an international actual entrepreneurial firm) was chosen to secure a deeper understanding of the role played by the business network in the SMEs' internationalization. To analyze the cases, an analytical framework was implemented that incorporated actor type, structural holes, and network closure throughout a process of international entrepreneurship. The findings showed that the actor type is the actual trigger of internationalization. This means companies that are surrounded by international actors are more likely to start or enter an international business market because they are in a better position to obtain the required knowledge about foreign markets. Further analysis revealed that having international actors around is not enough. This means that although being connected with more international actors is a principal factor for getting involved in 
international activities, it cannot ensure subsequent success. In fact, to act successfully in international business, a network structure should be designed in a way that enables companies to find and realize international opportunities both timely and efficiently. Final results supported by the current literature displayed a business network that is rich with structural holes in its external part and has a dense internal structure, could assist SMEs to explore and exploit opportunities faster and more efficiently. This was the case for the forced entrepreneurial company. It holds a network full of structural holes outside and was denser inside. Consequently;

From network perspective, there are three essential features, which explain how a network structure can influence the internationalization of SMEs. (1) having more international members in a business network that make accessing international information possible, (2) the diversity of acquired knowledge determined by the level of structural holes in the external part that helps to identify opportunities, and (3) the trust originating from the density of the internal part, which facilitates the opportunity exploitation through sharing technical knowledge and complementary resources.

Another interesting finding in the case of the forced entrepreneurial firm is the source of entrepreneurial orientation. It did not show a high degree of entrepreneurial orientation inside its formal borders, but there was an informal leader in the business network who held a high degree of entrepreneurial orientation and forced the resultant entrepreneurial action on the whole network through a special business mechanism. Consequently, by changing the level of analysis from the firm to its network, this case can be seen as an actual entrepreneurial business in which the orientation is located outside the formal borders.

\subsection{Research Contributions}

This study contributes in the current literature in different ways. First, it explored the current measurements of firm-level entrepreneurship, counted their strengths and weaknesses, and advised a combination of $\mathrm{EO}$ and $\mathrm{CE}$ as a more comprehensive way of measuring the phenomenon. It also took a further step, and criticized the current 
measurements that had synthesized EO and $\mathrm{CE}$, and proposed a profile measurement model of firm-level entrepreneurship. This profile measurement, which is new in the current literature, has a greater potential to draw a whole picture of firm-level entrepreneurship without having the usual deficiencies of other measurements.

Second, in agreement with the profile model, a categorical version of firm-level entrepreneurship was applied which delivers a more clear-cut explanation about the beneficial consequences of firm-level entrepreneurship. It has great potential to differentiate not only entrepreneurial and non-entrepreneurial companies, but also effectively classify entrepreneurial firms themselves into different groups, each showing a specific level of entrepreneurship. In company with the hierarchical regression techniques involving contrast coding, it provides a rich post-hoc analysis that enjoys the advantage of having less endogeneity concern.

Third, a systematic literature review incorporating the statistical techniques to infer the collective conclusions on the relationship of firm-level entrepreneurship and internationalization is another contribution of the research. There are a number of metastudies on the relationship of entrepreneurial orientation and performance in the literature, but as described before, they are completely different than what has been performed in this research. In this study, the focus has been placed on the association of firm-level entrepreneurship (an integrated construct of EO and $\mathrm{CE}$ ), and internationalization (operationalized as internationalization involvement, international performance and the speed of internationalization), not EO and corporate performance. Furthermore, the scope of the papers that are reviewed here are very different from previous studies. While existing reviews have paid more attention to the popular journals that mainly cover the empirical studies of developed countries, this research had a balanced focus on both popular and less popular journals which publish empirical studies on developing areas.

Fourth, the analytical framework and case study findings supported a network model of international entrepreneurship, which offers a rich explanation for the internationalization of entrepreneurial companies. It combines actor type, structural holes, and network closure in a way that explains how an internationalization process begins and 
proceeds. In addition, it provides a network description on the exploration and exploitation of international opportunities.

Finally, this study shows that relying only on entrepreneurial orientation at the firm level will not secure reliable and valid conclusions. Actually, there are some companies who are forced to depict some degree of entrepreneurial behavior despite their low inclination. A powerful leader in a business network may transfer its orientation to the whole network and build an actual entrepreneurial cooperation in which all the actors benefit from entrepreneurial outputs. Therefore, on some occasions, it is worth going beyond the firm to investigate entrepreneurship in a whole business network.

\subsection{Managerial Implications}

Managers and practitioners can also benefit from the research findings. They can use the profile model of firm-level entrepreneurship to determine their entrepreneurial status and set a practical plan to improve that. Although the findings are a little indecisive in terms of which entrepreneurial profile may help the best in the internationalization of smaller companies, it is obvious that showing some sort of entrepreneurial actions, voluntary or mandatory, can facilitate a company's successful internationalization. It should be mentioned that if companies are not inclined toward entrepreneurship, at least they should position themselves in an entrepreneurial business network to benefit from the collective innovative actions.

From the network point of view, SMEs need to communicate with international companies and build business networks with international actors who help them to obtain relevant information about international markets. For entering an international business network, finding and planning on similarities could be instructive. Companies need to find similar firms who are working in international markets; those similarities allow them to be accepted more easily in an international network. In addition, they should select an effective international network with spare external structure and dense internal structure to facilitate the exploration and exploitation of business opportunities. In fact, being connected to the external actors (customers or maybe suppliers) who are not connected together equips a company with a level of diversified information that helps to identify 
attractive opportunities. Having a dense internal network (competitors and perhaps suppliers) enables companies to exploit opportunities by increasing the level of trust as well as sharing resources and technical skills. All in all, managers are advised to lead their companies to business networks that contain more international firms, enjoy a dense structure of internal communication, and hold a spare group of external actors.

\subsection{Tips for Future Research}

There are some potential areas that may be ignored in this study because of delimitations, predispositions, cost, or time limit. Also, a number of post hoc ideas exist, which emerged during the process of the research, and are interesting enough to be studied more. These unnoticed areas and ideas remain intact and are proposed to future researchers as headlines that are worth consideration. Similar to all studies, this research leaves some questions unanswered which can be answered by future studies.

The principal literature defined EO and $\mathrm{CE}$ as reflective, three-dimensional constructs. As previously discussed, the number of dimensions is not a real concern of a reflective measurement; thus, researchers can examine different specifications of the constructs and select the one that fit best. In this study, just the unidimensional and threedimensional models were compared using structural equation modeling techniques. Future studies can extend this comparative technique to all the possible specifications of the constructs.

The profile model of firm-level entrepreneurship and its combination with network analysis provide a rich explanation regarding when and how entrepreneurial orientation can aid SMEs, but further investigations are required to see how companies can effectively manage their EO in a way that results in better $\mathrm{CE}$, and how the firm-level entrepreneurship activities should align with other organizational factors. Also, probing into the profile model of firm-level entrepreneurship during a specific period of time may lead to applicable instructions and implications, such as how a company should be managed to become an actual entrepreneurial business, and in which stage of a life cycle or under what conditions it could be better to act as a forced, a latent, or even a nonentrepreneurial firm. 
From the network analysis point of view, this research has mainly focused on network structure and the type of actor, and overlooked the dynamism behind the evolution of networks over time. In reality, entrepreneurial companies benefit from networks in all steps of their entrepreneurship process, and the outcome of what they have made in their early stages may support them in their later steps (Coviello, 2006). Moreover, following a longitudinal research strategy and studying business network over a period of time, has potential to yield a better explanation of internationalization process. By taking this into attention and applying a longitudinal perspective, future studies are better able to answer some important questions, such as: How do business networks form and evolve in a way that affects internationalization? How should entrepreneurial companies plan their networking strategies in a way that supports their future growth and performance?

Being in an entrepreneurial business network is not a permanent situation, and without precautions and proper maintenance, companies may lose their network positions. How companies build and maintain their network positions remains a gap in the literature that needs further investigation (Loane \& Bell, 2006). Future research should inquire into managing and maintaining a company's network position to some extent that maximizes efficiency, reduces external redundancy, and increases internal density. Also, the alignment of entrepreneurship and network positions is equally important and worth focusing on.

Evidently, more research is needed to obtain a universal generalizability of the findings. This research was conducted in a unique industry, in a single country, and among companies of a specific size; thus, it has its own limitation of generalizability. Consequently, a call for replication in other geographic areas, industries, and companies is needed. Besides, future studies can apply more recommended methods of construct measurement and data gathering, such as archival scale or collecting data using multiple informants. 


\section{Rertering}

(OECD), O. f. E. C.-o. D. (2005). Oslo Manual: Guidelines for Collecting and Interpreting Innovation Data (3rd ed.). Paris: OECD and Eurostat.

Acedo, F. J., \& Jones, M. V. (2007). Speed of Internationalization and Entrepreneurial Cognition: Insights and a Comparison between International New Ventures, Exporters and Domestic Firms. Journal of World Business, 42(3), 236-252. doi:10.1016/j.jwb.2007.04.012

Achtenhagen, L. (2011). Internationalization Competence of SMEs. Swedish Entrepreneurship Forum.

Acs, Z. J., Morck, R. K., \& Yeung, B. (2001). Entrepreneurship, Globalization, and Public Policy. Journal of International Management, 7(3), 235-251.

Acs, Z. J., \& Preston, L. (1997). Small and Medium-Sized Enterprises, Technology, and Globalization: Introduction to a special issue on Small and Medium-Sized Enterprises in the Global Economy. Small business economics, 9(1), 1-6. doi:Doi 10.1023/A:1007945327618

Adler, P. S., \& Kwon, S. W. (2002). Social Capital: Prospects for a New Concept. Academy of management review, 27(1), 17-40. doi:Doi 10.2307/4134367

Adonisi, M., \& Van Wyk, R. (2012). The relationship between Corporate Entrepreneurship, Market Orientation, Organisational Flexibility and Job Satisfaction. International Business \& Economics Research Journal (IBER), 11(5), 477-486.

Ahimbisibwe, M. G., \& Abaho, E. (2013). Export Entrepreneurial Orientation And Export Performance Of Smes In Uganda. Global Advanced Research Journal of Management and Business Studies, 2(1), 56-62.

Ahuja, G. (2000). Collaboration Networks, Structural Holes, and Innovation: A Longitudinal Study. Administrative science quarterly, 45(3), 425-455. doi:Doi 10.2307/2667105

Ajdari, B. (2007). Impact of E-commerce on Internationalization of Iranian SMEs. (Master Thesis), Luleå University of Technology, Lulea, Sweden. 
Al-Laham, A., \& Souitaris, V. (2008). Network Embeddedness and New Venture Internationalization. Analyzing International Linkages in the German Biotech Industry. Journal of Business Venturing, 23(5), 567-586. doi:DOI 10.1016/j.jbusvent.2007.09.001

Aldrich, H. E., \& Zimmer, C. (1986). Entrepreneurship through Social Networks. In D. L. Sexton \& R. W. Smilor (Eds.), The art and science of entrepreneurship (pp. 3-23). Cambridge: MA: Ballinger.

Alegre, J., \& Chiva, R. (2013). Linking Entrepreneurial Orientation and Firm Performance: The Role of Organizational Learning Capability and Innovation Performance. Journal of Small Business Management, 51(4), 491-507. doi:10.1111/jsbm.12005

Alvarez, S. A., \& Busenitz, L. W. (2001). The Entrepreneurship of Resource-based Theory. Journal of Management, 27(6), 755-775. doi:Doi 10.1177/014920630102700609

Andersen, O. (1993). On the Internationalization Process of Firms: A Critical Analysis. Journal of International Business Studies, 24(2), 209-231. doi:DOI 10.1057/palgrave.jibs. 8490230

Anderson, B. S., \& Eshima, Y. (2013). The Influence of Firm Age and Intangible Resources on the Relationship between Entrepreneurial Orientation and Firm Growth among Japanese SMEs. Journal of Business Venturing, 28(3), 413-429. doi:DOI 10.1016/j.jbusvent.2011.10.001

Anderson, B. S., Kreiser, P. M., Kuratko, D. F., Hornsby, J. S., \& Eshima, Y. (2014). Reconceptualizing Entrepreneurial Orientation. Strategic Management Journal, 36(10), 1579-1596. doi:10.1002/smj.2298

Anderson, J. C., \& Gerbing, D. W. (1988). Structural Equation Modeling in Practice: A Review and Recommended Two-Step Approach. Psychological Bulletin, 103(3), 411-423. doi:10.1037/0033-2909.103.3.411

Andersson, S. (2000). The Internationalization of the Firm from an Entrepreneurial Perspective. International Studies of Management \& Organization, 30(1), 63-92.

Andersson, S., \& Wictor, I. (2003). Innovative Internationalisation in New Firms: Born Globalsthe Swedish Case. Journal of International Entrepreneurship, 1(3), 249-276. doi:10.1023/A:1024110806241

Antoncic, B. (2007). Intrapreneurship: A Comparative Structural Equation Modeling Study. Industrial Management \& Data Systems, 107(3-4), 309-325. doi:Doi $10.1108 / 02635570710734244$

Antoncic, B., Cardon, M. S., \& Hisrich, R. D. (2004). Internationalizing Corporate Entrepreneurship: The Impact on Global HR Management. In A. J. Katz \& D. A. Shepherd (Eds.), Advances in Entrepreneurship, Firm Emergence and Growth (Vol. 7, pp. 173197): Emerald Group Publishing Limited.

Antoncic, B., \& Hisrich, R. D. (2001). Intrapreneurship: Construct Refinement and Cross-Cultural Validation. Journal of Business Venturing, 16(5), 495-527. doi:Doi 10.1016/S08839026(99)00054-3

Antoncic, B., \& Hisrich, R. D. (2003). Clarifying the Intrapreneurship Concept. Journal of Small Business and Enterprise Development, 10(1), 7-24. doi:10.1108/14626000310461187 
Antoncic, B., \& Hisrich, R. D. (2004). Corporate Entrepreneurship Contingencies and Organizational Wealth Creation. Journal of Management Development, 23(6), 518-550. doi:10.1108/02621710410541114

Armstrong, J. S., \& Overton, T. S. (1977). Estimating Nonresponse Bias in Mail Surveys. Journal of marketing research, 14(3), 396-402.

Atuahene-Gima, K., \& Ko, A. (2001). An Empirical Investigation of the Effect of Market Orientation and Entrepreneurship Orientation Alignment on Product Innovation. Organization Science, 12(1), 54-74.

Auh, S., \& Menguc, B. (2005). Balancing Exploration and Exploitation: The Moderating Role of Competitive Intensity. Journal of Business Research, 58(12), 1652-1661. doi:DOI 10.1016/j.jbusres.2004.11.007

Autio, E., Sapienza, H. J., \& Almeida, J. G. (2000). Effects of Age at Entry, Knowledge Intensity, and Imitability on International Growth. Academy of Management Journal, 43(5), 909924. doi:10.2307/1556419

Axelsson, B., \& Agndal, H. (2000). Internationalization of the Firm. A Note on the Crucial Role of the Individual's Contact Network. Paper presented at the IMP conference, Bath, U.K.

Bagozzi, R. P., \& Youjae, Y. (1988). On the Evaluation of Structural Equation Models. Journal of the Academy of Marketing Science, 16(1), 74-94.

Baker, W. E., \& Sinkula, J. M. (2009). The Complementary Effects of Market Orientation and Entrepreneurial Orientation on Profitability in Small Businesses. Journal of Small Business Management, 47(4), 443-464.

Balabanis, G. I., \& Katsikea, E. S. (2003). Being an Entrepreneurial Exporter: Does It Pay? International Business Review, 12(2), 233-252. doi:10.1016/s0969-5931(02)00098-7

Balkundi, P., \& Harrison, D. A. (2006). Ties, Leaders, and Time in Teams: Strong Inference about Network Structure's Effects on Team Viablility and Performance. Academy of Management Journal, 49(1), 49-68. doi:10.5465/AMJ.2006.20785500

Barnett, V., \& Lewis, T. (1978). Outliers in Statistical Data (3rd ed.). Bath, U.K.: John Wiley \& Sons Ltd.

Barney, J. (1991). Firm Resources and Sustained Competitive Advantage. Journal of Management, 17(1), 99-120. doi:Doi 10.1177/014920639101700108

Barney, J., Wright, M., \& Ketchen, D. J. (2001). The Resource-Based View of the Firm: Ten Years After 1991. Journal of Management, 27(6), 625-641. doi:Doi $10.1177 / 014920630102700601$

Becherer, R. C., \& Maurer, J. G. (1997). The Moderating Effect of Environmental Variables on the Entrepreneurial and Marketing Orientation of Entrepreneur-led Firms. Entrepreneurship: Theory \& Practice, 22(1), 47-58.

Bell, J. (1995). The Internationalization of Small Computer Software Firms: A Further Challenge to "Stage" Theories. European journal of marketing, 29(8), 60-75. doi:10.1108/03090569510097556

Bilkey, W. J. (1978). An Attempted Integration of the Literature on the Export Behavior of Firms. Journal of International Business Studies, 9(1), 33-46. 
Blanchflower, D. G., Oswald, A., \& Stutzer, A. (2001). Latent Entrepreneurship Across Nations. European Economic Review, 45(4-6), 680-691.

Bloodgood, J. M., Sapienza, H. J., \& Almeida, J. G. (1996). The Internationalization of New HighPotential U.S. Ventures: Antecedents and Outcomes. Entrepreneurship: Theory \& Practice, 20(4), 61-76.

Bojica, A. M., \& Fuentes, M. D. F. (2012). Knowledge Acquisition and Corporate Entrepreneurship: Insights from Spanish SMEs in the ICT Sector. Journal of World Business, 47(3), 397-408. doi:10.1016/j.jwb.2011.05.007

Boojihawon, D. K. (2004). International Entrepreneurship and Network Relationships: The International Marketing Communications Sector. In M. V. Jones \& P. Dimitratos (Eds.), Emerging Paradigms in International Entrepreneurship (1 ed., pp. 217-248). Camberley, UK: Edward Elgar Publishing.

Borgatti, S. P., Everett, M. G., \& Johnson, J. C. (2013). Analyzing Social Networks: SAGE Publications.

Bosma, N., \& Harding, R. (2007). Global Entrepreneurship Monitor: GEM 2006 Summary Results.

Boso, N. (2010). Export Entrepreneurial-Eriented Behaviour and Export Performance. (Doctor of Philosophy Doctoral Thesis), Loughborough University.

Boso, N., Cadogan, J. W., \& Story, V. M. (2012a). Complementary Effect of Entrepreneurial and Market Orientations on Export New Product Success under Differing Levels of Competitive Intensity and Financial Capital. International Business Review, 21(4), 667681. doi:10.1016/j.ibusrev.2011.07.009

Boso, N., Cadogan, J. W., \& Story, V. M. (2012b). Entrepreneurial Orientation and Market Orientation as Drivers of Product Innovation Success: A Study of Exporters from a Developing Economy. International Small Business Journal, 31(1), 57-81. doi:10.1177/0266242611400469

Boso, N., Story, V. M., Cadogan, J. W., Micevski, M., \& Kadic-Maglajlic, S. (2013). Firm Innovativeness and Export Performance: Environmental Networking, and Structural Contingencies. Journal of International Marketing, 21(4), 62-87. doi:10.1509/jim.13.0052

Boter, H., \& Holmquist, C. (1996). Industry Characteristics and Internationalization Processes in Small Firms. Journal of Business Venturing, 11(6), 471-487. doi:Doi 10.1016/S08839026(96)89166-X

Bouchard, V., \& Basso, O. (2011). Exploring the Links between Entrepreneurial Orientation and Intrapreneurship in SMEs. Journal of Small Business and Enterprise Development, 18(2), 219-231. doi:10.1108/14626001111127043

Bowerman, B. L., \& O'Connell, R. T. (1990). Linear Statistical Models: An Applied Approach (2nd ed. Vol. 0): Duxbury Press.

Brass, D. J., Galaskiewicz, J., \& Greve, H. R. (2004). Taking Stock of Networks and Organizations: A Multilevel Perspective. Academy of Management Journal, 47(6), 795817. doi:10.2307/20159624 
Brixy, U., Sternberg, R., \& Stuber, H. (2012). The Selectiveness of the Entrepreneurial Process. Journal of Small Business Management, 50(1), 105-131. doi:10.1111/j.1540627X.2011.00346.X

Brown, T. E., Davidsson, P., \& Wiklund, J. (2001). An Operationalization of Stevenson's Conceptualization of Entrepreneurship as Opportunity-Based Firm Behavior. Strategic Management Journal, 22(10), 953-968.

Browne, M. W., \& Cudeck, R. (1989). Single Sample Cross-Validation Indices for Covariance Structures. Multivariate Behavioral Research, 24(4), 445-455.

Bryman, A. (2012). Social Research Methods (4th ed.). New York: Oxford University Press.

Buckley, P. J. (1988). The Limits of Explanation: Testing the Internalization Theory of the Multinationial Enterprise. Journal of International Business Studies, 19(2), 181-193.

Burgelman, R. A. (1983). Corporate Entrepreneurship and Strategic Management: Insights from a Process Study. Management science, 29(12), 1349-1364. doi:DOI $10.1287 / \mathrm{mnsc} .29 .12 .1349$

Burgelman, R. A. (1984). Designs for Corporate EntrepreneurshipIn Established Firms. California Management Review, XXVI(3), 154-166.

Burt, R. S. (1992). The Social Structure of Competition. In N. Nohria \& R. G. Eccles (Eds.), Networks and organizations : structure, form and action (pp. 58-91). Boston, Mass.: Harvard Business School Press.

Burt, R. S. (1997). The Contingent value of Social Capital. Administrative science quarterly, 42(2), 339-365. doi:Doi 10.2307/2393923

Burt, R. S. (1999). Entrepreneurs, Distrust, and Third Parties: A Strategic Look at the Dark Side of Dense Networks. In J. M. Levine, L. L. Thompson, \& D. M. Messick (Eds.), Shared Cognition in Organizations: The Management of Knowledge (pp. 213-243). Mahwah, NJ, US: Lawrence Erlbaum Associates Publishers.

Burt, R. S. (2000). The Network Structure of Social Capital. Research in organizational behavior, 22, 345-423. doi:Doi 10.1016/S0191-3085(00)22009-1

Burt, R. S. (2001a). Bandwidth and Echo: Trust, Information, and Gossip in Social Networks. In J. E. Rauch \& A. Casella (Eds.), Networks and Markets (pp. 30-74). New York: Russell Sage Foundation.

Burt, R. S. (2001b). Structural Holes versus Network Closure as Social Capital. In N. Lin, K. Cook, \& R. S. Burt (Eds.), Social Capital: Theory and Research (pp. 31-56). New York: Aldine de Gruyter.

Burt, R. S., Hogarth, R. M., \& Michaud, C. (2000). The Social Capital of French and American Managers. Organization Science, 11(2), 123-147. doi:DOI 10.1287/orsc.11.2.123.12506

Buskens, V., \& van de Rijt, A. (2008). Dynamics of Networks if Everyone Strives for Structural Holes1. American Journal of Sociology, 114(2), 371-407. doi:10.1086/590674

Byrne, B. M. (2013). Structural Equation Modeling With AMOS: Basic Concepts, Applications, and Programming (2nd (Revised) ed.). New York: Routledge.

Byrne, B. M., \& Gavin, D. A. W. (1996). The Shavelson Model Revisited: Testing for the Structure of Academic Self-Concept Across Pre-, Early, and Late Adolescents. Journal of Educational Psychology, 88(2), 215-228. doi:Doi 10.1037/0022-0663.88.2.215 
Byrne, B. M., \& Shavelson, R. J. (1996). On the Structure of Social Self-Concept for Pre-, Early, and Late Adolescents: A Test of the Shavelson, Hubner, and Stanton (1976) Model. Journal of Personality and Social Psychology, 70(3), 599-613. doi:10.1037/00223514.70.3.599

Cadogan, J. W., Kuivalainen, O., \& Sundqvist, S. (2009). Export Market-Oriented Behavior and Export Performance: Quadratic and Moderating Effects Under Differing Degrees of Market Dynamism and Internationalization. Journal of International Marketing, 17(4), 71-89. doi:doi:10.1509/jimk.17.4.71

Calantone, R. J., Kim, D., Schmidt, J. B., \& Cavusgil, S. T. (2006). The Influence of Internal and External Firm Factors on International Product Adaptation Strategy and Export Performance: A Three-Country Comparison. Journal of Business Research, 59(2), 176185. doi:10.1016/j.jbusres.2005.05.001

Calof, J. L., \& Beamish, P. W. (1995). Adapting to Foreign Markets: Explaining Internationalization. International Business Review, 4(2), 115-131.

Carland, J. W., Hoy, F., Boulton, W. R., \& Carland, J. A. C. (1984). Differentiating Entrepreneurs from Small Business Owners: A Conceptualization. Academy of management review, 9(2), 354-359. doi:Doi 10.2307/258448

Caruana, A., Ewing, M. T., \& Ramaseshan, B. (2002). Effects of some Environmental Challenges and Centralization on the Entrepreneurial Orientation and Performance of Public Sector Entities. Service Industries Journal, 22(2), 43-58. doi:Doi 10.1080/714005076

Casillas, J. C., \& Moreno, A. M. (2010). The Relationship between Entrepreneurial Orientation and Growth: The Moderating Role of Family Involvement. Entrepreneurship and Regional Development, 22(3-4), 265-291. doi:Pii 924644952

\section{$10.1080 / 08985621003726135$}

Casson, M. C. (1986). General theories of the Multinational Enterprise: Their Relevance to Business History. In P. Hertner \& G. Jones (Eds.), Multinationals: Theory and History (pp. 42-63). England: Gower Publishing Ltd.

Caves, R. E. (1971). International Corporations: The Industrial Economics of Foreign Investment. Economica, 38(149), 1-27.

Cavusgil, S. T., \& Zou, S. M. (1994). Marketing Strategy-Performance Relationship: An Investigation of the Empirical Link in Export Market Ventures. Journal of Marketing, 58(1), 1-21. doi:Doi 10.2307/1252247

Chandler, G. N., \& Lyon, D. W. (2001). Issues of Research Design and Construct Measurement in Entrepreneurship Research: The Past Decade. Entrepreneurship: Theory \& Practice, 25(4), 101-113.

Chandra, Y., Styles, C., \& Wilkinson, I. (2009). The Recognition of First Time International Entrepreneurial Opportunities: Evidence from Firms in Knowledge-Based Industries. International Marketing Review, 26(1), 30-61. doi:10.1108/02651330910933195

Chang, S. J., van Witteloostuijn, A., \& Eden, L. (2010). From the Editors: Common Method Variance in International Business Research. Journal of International Business Studies, 4l(2), 178-184. doi:10.1057/jibs.2009.88 
Chen, H. L., \& Hsu, C. H. (2013). Entrepreneurial Orientation and Firm Performance in NonProfit Service Organizations: Contingent Effect of Market Orientation. Service Industries Journal, 33(5), 445-466. doi:10.1080/02642069.2011.622372

Chetty, S., \& Blankenburg Holm, D. (2000a). Internationalisation of Small to Medium-sized Manufacturing Firms: A Network Approach. International Business Review, 9(1), 77-93.

Chetty, S., \& Blankenburg Holm, D. (2000b). The Role of Business Networks in the Internationalisation of Manufacturing Firms: A Longitudinal Case Study Developments in Australianasian Marketing: Advances in International Marketing (pp. 205-222): JAI Press.

Chetty, S., \& Campbell-Hunt, C. (2004). A Strategic Approach to Internationalization: A Traditional Versus a "Born-Global” Approach. Journal of International Marketing, 12(1), 57-81.

Chetty, S. K., \& Stangl, L. M. (2010). Internationalization and Innovation in a Network Relationship Context. European journal of marketing, 44(11-12), 1725-1743. doi:10.1108/03090561011079855

Chetty, S. K., \& Wilson, H. I. M. (2003). Collaborating with Competitors to Acquire Resources. International Business Review, 12(1), 61-81. doi:10.1016/s0969-5931(02)00088-4

Clercq, D. D., Sapienza, H. J., \& Crijns, H. (2005). The Internationalization of Small and MediumSized Firms. Small business economics, 24(4), 409-419. doi:10.1007/s11187-005-5333-x

Cohen, J., Cohen, P., West, S. G., \& Aiken, L. S. (2003). Applied Multiple Regression/Correlation Analysis for the Behavioral Sciences (3td ed.): Routledge.

Coleman, J. S. (1988). Social Capital in the Creation of Human Capital. American Journal of Sociology, 94(Supplement), S95-S120. doi:Doi 10.1086/228943

Coleman, J. S. (1990). Foundations of Social Theory. Cambridge: Belknap Press of Harvard University Press.

Commission, E. (2003). Commisson Recommendation of 6 May 2003: Concerning the Definition of Micro, Small and Medium-Sized Enterprises. Official Journal of the European Union, $L(124), 36-41$.

conner, K. R. (1991). A Historical Comparison of Resource-Based Theory and Five Schools of Thought Within Industrial Organization Economics: Do We Have a New Theory of the Firm? Journal of Management, 17(1), 121-154.

Cook, K. S., \& Emerson, R. M. (1978). Power, Equity and Commitment in Exchange Networks. American sociological review, 43(5), 721-739. doi:Doi 10.2307/2094546

Corbett, A., Covin, J. G., O'Connor, G. C., \& Tucci, C. L. (2013). Corporate Entrepreneurship: State-of-the-Art Research and a Future Research Agenda. Journal of product innovation management, 30(5), 812-820. doi:10.1111/jpim.12031

Costa, A. C. (2003). Work Team Trust and Effectiveness. Personnel Review, 32(5), 605-622. doi: $10.1108 / 00483480310488360$

Coviello, N. E. (2006). The Network Dynamics of International New Ventures. Journal of International Business Studies, 37(5), 713-731. doi:10.1057/palgrave.jibs.8400219 
Coviello, N. E., \& Jones, M. V. (2004). Methodological Issues in International Entrepreneurship Research. Journal of Business Venturing, 19(4), 485-508. doi:10.1016/j.jbusvent.2003.06.001

Coviello, N. E., \& McAuley, A. (1999). Internationalisation and the Smaller Firm: A Review of Contemporary Empirical Research. Management International Review, 39(3), 223-237.

Coviello, N. E., \& Munro, H. J. (1995). Growing the Entrepreneurial Firm: Networking for International Market Development. European journal of marketing, 29(7), 49-61.

Coviello, N. E., \& Munro, H. J. (1997). Network Relationships and the Internationalization Process of Small Software Firms. International Business Review, 6(4), 361-386.

Covin, J. G., Green, K. M., \& Slevin, D. P. (2006). Strategic process effects on the entrepreneurial orientation-sales growth rate relationship. Entrepreneurship: Theory \& Practice, 30(1), 57-81. doi:DOI 10.1111/j.1540-6520.2006.00110.x

Covin, J. G., \& Lumpkin, G. T. (2011). Entrepreneurial Orientation Theory and Research: Reflections on a Needed Construct. Entrepreneurship: Theory \& Practice, 35(5), 855872. doi:10.1111/j.1540-6520.2011.00482.x

Covin, J. G., \& Miles, M. P. (1999). Corporate Entrepreneurship and the Pursuit of Competitive Advantage. Entrepreneurship: Theory \& Practice, 23(3), 47-63.

Covin, J. G., \& Miller, D. (2013). International Entrepreneurial Orientation: Conceptual Considerations, Research Themes, Measurement Issues, and Future Research Directions. Entrepreneurship: Theory \& Practice, 38(1), 11-44. doi:10.1111/etap.12027

Covin, J. G., \& Slevin, D. P. (1989). Strategic Management of Small Firms in Hostile and Benign Environments. Strategic Management Journal, 10(1), 75-87. doi:DOI $10.1002 / \mathrm{smj} .4250100107$

Covin, J. G., \& Slevin, D. P. (1991). A Conceptual Model of Entrepreneurship as Firm Behavior. Entrepreneurship: Theory \& Practice, 16(1), 7-25.

Covin, J. G., \& Slevin, D. P. (1993). A Response to Zhara's Critique and Extension of the CovinSlevin Entrepreneurship Model. Entrepreneurship: Theory \& Practice, 17(4), 23-28.

Covin, J. G., Slevin, D. P., \& Covin, T. J. (1990). Content and Performance of Growth-Seeking Strategies - a Comparison of Small Firms in High-Technology and Low-Technology Industries. Journal of Business Venturing, 5(6), 391-412. doi:Doi 10.1016/08839026(90)90013-J

Covin, J. G., Slevin, D. P., \& Schultz, R. L. (1994). Implementing Strategic Missions: Effective Strategic, Structural and Tactical Choices. Journal of Management Studies, 31(4), 481505. doi:DOI 10.1111/j.1467-6486.1994.tb00627.x

Covin, J. G., \& Wales, W. J. (2012). The Measurement of Entrepreneurial Orientation. Entrepreneurship: Theory \& Practice, 36(4), 677-702. doi:10.1111/j.15406520.2010.00432.x

Creswell, J. W. (2013). Qualitative Inquiry and Research Design: Choosing Among Five Approaches (3rd ed.). USA: SAGE Publications.

Crick, D., \& Jones, M. V. (2000). Small High-Technology Firms and International HighTechnology Markets. Journal of International Marketing, 8(2), 63-85. 
Crick, D., \& Spence, M. (2005). The Internationalisation of "High Performing" UK High-Tech SMEs: A Study of Planned and Unplanned Strategies. International Business Review, 14(2), 167-185. doi:10.1016/j.ibusrev.2004.04.007

Czinkota, M. R., \& Johnston, W. J. (1981). Segmenting U.S. Firms for Export Development. Journal of Business Research, 9(4), 353-365. doi:10.1016/0148-2963(81)90012-6

Dai, L., Maksimov, V., Gilbert, B. A., \& Fernhaber, S. A. (2014). Entrepreneurial Orientation and International Scope: The Differential Roles of Innovativeness, Proactiveness, and RiskTaking. Journal of Business Venturing, 29(4), 511-524. doi:10.1016/j.jbusvent.2013.07.004

Damanpour, F. (1991). Organizational Innovation: A Meta-Analysis of Effects of Determinants and Moderators. Academy of Management Journal, 34(3), 555-590.

Davis-Blake, A., \& Pfeffer, J. (1989). Just a Mirage: The Search for Dispositional Effects in Organizational Research. Academy of management review, 14(3), 385-400.

Davis, J. L., Greg Bell, R., Tyge Payne, G., \& Kreiser, P. M. (2010). Entrepreneurial Orientation and Firm Performance: The Moderating Role of Managerial Power. American Journal of Business, 25(2), 41-54. doi:10.1108/19355181201000009

Davis, M. J. (2010). Contrast Coding in Multiple Regression Analysis: Strengths, Weaknesses, and Utility of Popular Coding Structures. Journal of Data Science, 8, 61-73.

de Kok, J., Vroonhof, P., Verhoeven, W., Timmermans, N., Kwaak, T., Snijders, J., \& Westhof, F. (2011). Do SMEs Create More and Better Jobs?

Dess, G. G., Ireland, R. D., Zahra, S. A., Floyd, S. W., Janney, J. J., \& Lane, P. J. (2003). Emerging Issues in Corporate Entrepreneurship. Journal of Management, 29(3), 351-378. doi:10.1016/S0149-2063(03)00015-1

Dess, G. G., \& Lumpkin, G. T. (2005). The Role of Entrepreneurial Orientation in Stimulating Effective Corporate Entrepreneurship. Academy of Management Executive, 19(1), 147156.

Dess, G. G., Lumpkin, G. T., \& Covin, J. G. (1997). Entrepreneurial Strategy Making and Firm Performance: Tests of Contingency and Configurational Models. Strategic Management Journal, 18(9), 677-695.

Dess, G. G., Lumpkin, G. T., \& McGee, J. E. (1999). Linking Corporate Entrepreneurship to Strategy, Structure, and Process: Suggested Research Directions. Entrepreneurship: Theory \& Practice, 23(3), 85-102.

Dess, G. G., Pinkham, B. C., \& Yang, H. (2011). Entrepreneurial Orientation: Assessing the Construct's Validity and Addressing Some of Its Implications for Research in the Areas of Family Business and Organizational Learning. Entrepreneurship: Theory \& Practice, 35(5), 1077-1090. doi:10.1111/j.1540-6520.2011.00480.x

Dess, G. G., \& Robinson, R. B. (1984). Measuring Organizational Performance in the Absence of Objective Measures - the Case of the Privately-Held Firm and Conglomerate Business Unit. Strategic Management Journal, 5(3), 265-273. doi:DOI 10.1002/smj.4250050306

Dhanaraj, C., \& Beamish, P. W. (2003). A Resource-Based Approach to the Study of Export Performance. Journal of Small Business Management, 41(3), 242-261. doi:Doi $10.1111 / 1540-627 x .00080$ 
Diamantopoulos, A., Riefler, P., \& Roth, K. P. (2008). Advancing formative measurement models. Journal of Business Research, 61(12), 1203-1218. doi:10.1016/j.jbusres.2008.01.009

Dimitratos, P., Lioukas, S., \& Carter, S. (2004). The Relationship Between Entrepreneurship and International Performance: The Importance of Domestic Environment. International Business Review, 13(1), 19-41.

Dimitratos, P., Plakoyiannaki, E., Pitsoulaki, A., \& Tuselmann, H. J. (2010). The Global Smaller Firm in International Entrepreneurship. International Business Review, 19(6), 589-606. doi:10.1016/j.ibusrev.2010.03.005

Dimitratos, P., Voudouris, I., Plakoyiannaki, E., \& Nakos, G. (2012). International Entrepreneurial Culture: Toward a Comprehensive Opportunity-Based Operationalization of International Entrepreneurship. International Business Review, 21(4), 708-721. doi:10.1016/j.ibusrev.2011.08.001

Dunning, J. H. (1980). Toward an Eclectic Theory of International Production: Some Empirical Tests. Journal of International Business Studies, 11(1), 9-31. doi:DOI 10.1057/palgrave.jibs. 8490593

Dunning, J. H. (1988). The Eclectic Paradigm of International Production: A Restatement and Some Possible Extensions. Journal of International Business Studies, 19(1), 1-31. doi:DOI 10.1057/palgrave.jibs.8490372

Dyer, J. H., \& Nobeoka, K. (2000). Creating and Managing a High Performance KnowledgeSharing Network: The Toyota Case. Strategic Management Journal, 21(3), 345-367. doi:Doi 10.1002/(Sici)1097-0266(200003)21:3<345::Aid-Smj96>3.0.Co;2-N

Easton, G. (1998). Case Research as a Methodology for Industrial Networks: A Realist Apologia. In P. Naudé \& P. W. Turnbull (Eds.), Network Dynamics in International Marketing (pp. 73-87). New York: Emerald Group Publishing Limited.

Edwards, J. R. (2001). Multidimensional Constructs in Organizational Behavior Research: An Integrative Analytical Framework. Organizational Research Methods, 4(2), 144-192. doi:Doi 10.1177/109442810142004

Eggers, F., Kraus, S., Hughes, M., Laraway, S., \& Snycerski, S. (2013). Implications of Customer and Entrepreneurial Orientations for SME Growth. Management Decision, 51(3), 524546. doi:10.1108/00251741311309643

Eisenhardt, K. M. (1989). Building Theories from Case-Study Research. Academy of management review, 14(4), 532-550. doi:Doi 10.2307/258557

Elango, B., \& Pattnaik, C. (2007). Building Capabilities for International Operations through Networks: A Study of Indian Firms. Journal of International Business Studies, 38(4), 541555. doi:10.1057/palgrave.jibs. 8400280

Ellis, P., \& Pecotich, A. (2001). Social Factors Influencing Export Initiation in Small and MediumSized Enterprises. Journal of marketing research, 38(1), 119-130. doi:DOI 10.1509/jmkr.38.1.119.18825

Ellis, P. D. (2011). Social Ties and International Entrepreneurship: Opportunities and Constraints Affecting Firm Internationalization. Journal of International Business Studies, 42(1), 99127. doi: $10.1057 /$ jibs. 2010.20

Etemad, H. (1999). Globalization and Small and Medium-Sized Enterprises: Search for Potent Strategies. Global Focus, (formerly Business and Contemporary World), 11(3), 85-105. 
Etemad, H. (2004). Internationalization of Small and Medium-sized Enterprises: A Grounded Theoretical Framework and an Overview. Canadian Journal of Administrative Sciences/Revue Canadienne des Sciences de l'Administration, 21(1), 1-21.

Faems, D., Janssens, M., Madhok, A., \& Van Looy, B. (2008). Toward an Integrative Perspective on Alliance Governance: Connecting Contract Design, Trust Dynamics, and Contract Application. Academy of Management Journal, 51(6), 1053-1078. doi:10.2307/40390262

Field, A. (2013). Discovering Statistics using IBM SPSS Statistics (M. Carmichael Ed. 3rd ed.). Canada: SAGE Publications.

Fischer, E. M., Reuber, A. R., \& Dyke, L. S. (1993). A Theoretical Overview and Extension of Research on Sex, Gender, and Entrepreneurship. Journal of Business Venturing, 8(2), 151-168. doi:Doi 10.1016/0883-9026(93)90017-Y

Fletcher, R. (2001). A Holistic Approach to Internationalisation. International Business Review, 10(1), 25-49.

Fletcher, R. (2008). The Internationalisation from a Network Perspective: A Longitudinal Study. Industrial Marketing Management, 37(8), 953-964. doi:10.1016/j.indmarman.2007.09.008

Fletcher, R., \& Barrett, N. (2001). Embeddedness and the Evolution of Global Networks: An Australian Case Study. Industrial Marketing Management, 30(7), 561-573. doi:Doi 10.1016/S0019-8501(99)00120-0

Floyd, S. W., \& Lane, P. J. (2000). Strategizing throughout the Organization: Managing Role Conflict in Strategic Renewal. The Academy of Management Review, 25(1), 154-177.

Ford, J. K., Maccallum, R. C., \& Tait, M. (1986). The Application of Exploratory Factor-Analysis in Applied-Psychology: A Critical-Review and Analysis. Personnel Psychology, 39(2), 291-314. doi:DOI 10.1111/j.1744-6570.1986.tb00583.x

Fornell, C., \& Larcker, D. F. (1981). Structural Equation Models with Unobservable Variables and Measurement Error: Algebra and Statistics. Journal of marketing research, 18(3), 382-388. doi:Doi 10.2307/3150980

Francis, R., \& Collins-Dodd, C. (2000). The Impact of Firms' Export Orientation on the Export Performance of High-Tech Small and Medium-Sized Enterprises. Journal of International Marketing, 8(3), 84-103. doi:10.1509/jimk.8.3.84.19631

Freeman, J., Carroll, G. R., \& Hannan, M. T. (1983). The Liability of Newness: Age Dependence in Organizational Death Rates. American sociological review, 48(5), 692-710.

Freeman, S., \& Cavusgil, S. T. (2007). Toward a Typology of Commitment States Among Managers of Born-Global Firms: A Study of Accelerated Internationalization. Journal of International Marketing, 15(4), 1-40. doi:DOI 10.1509/jimk.15.4.1

Freeman, S., Edwards, R., \& Schroder, B. (2006). How Smaller Born-Global Firms Use Networks and Alliances to Overcome Constraints to Rapid Internationalization. Journal of International Marketing, 14(3), 33-63. doi:DOI 10.1509/jimk.14.3.33

Frishammar, J., \& Andersson, S. (2008). The Overestimated Role of Strategic Orientations for International Performance in Smaller Firms. Journal of International Entrepreneurship, 7(1), 57-77. doi:10.1007/s10843-008-0031-9 
Garcia-Morales, V. J., Bolivar-Ramos, M. T., \& Martin-Rojas, R. (2014). Technological Variables and Absorptive Capacity's Influence on Performance through Corporate Entrepreneurship. Journal of Business Research, 67(7), 1468-1477. doi:10.1016/j.jbusres.2013.07.019

Garcia, R., \& Calantone, R. (2002). A Critical Look at Technological Innovation Typology and Innovativeness Terminology: A Literature Review. Journal of product innovation management, 19(2), 110-132. doi:Pii S0737-6782(01)00132-1

Doi 10.1111/1540-5885.1920110

Gartner, W. B., \& Baker, T. (2010). A Plausible History and Exploration of Stevenson's Definition of Entrepreneurship. Paper presented at the Frontiers of entrepreneurship research.

George, B. A. (2011). Entrepreneurial Orientation: A Theoretical and Empirical Examination of the Consequences of Differing Construct Representations. Journal of Management Studies, 48(6), 1291-1313. doi:10.1111/j.1467-6486.2010.01004.x

George, B. A., \& Marino, L. (2011). The Epistemology of Entrepreneurial Orientation: Conceptual Formation, Modeling, and Operationalization. Entrepreneurship: Theory \& Practice, 35(5), 989-1024. doi:10.1111/j.1540-6520.2011.00455.x

George, G., Wiklund, J., \& Zahra, S. A. (2005). Ownership and the Internationalization of Small Firms. Journal of Management, 31(2), 210-233. doi:10.1177/0149206304271760

George, G., Wood, D. R., \& Khan, R. (2001). Networking Strategy of Boards: Implications for Small and Medium-Sized Enterprises. Entrepreneurship and Regional Development, 13(3), 269-285. doi:10.1080/08985620110058115

Ghanatabadi, F. (2005). Internationalization of Small and Medium-sized Enterprises in Iran. (Doctoral Thesis), Luleå University of Technology, Luleå, Sweden.

Ghauri, P., Lutz, C., \& Tesfom, G. (2003). Using Networks to Solve Export-Marketing Problems of Small- and Medium-Sized Firms from Developing Countries. European journal of marketing, 37(5/6), 728-752.

Gilpin, R. (2002). The Challenge of Global Capitalism: The World Economy in the 21st Century (5th ed.): Princeton University Press.

Gomes- Casseres, B. (1997). Alliance Strategies of Small Firms. Small business economics, 9(1), 33-44. doi:10.1023/a:1007947629435

Goosen, C. J., De Coning, T. J., \& Smit, E. v. d. M. (2003). The Development of a Factor Based Instrument to Measure Corporate Entrepreneurship: A South African Perspective. journal of business management, 33(3), 39-51.

Granovetter, M. (1985). Economic-Action and Social-Structure - the Problem of Embeddedness. American Journal of Sociology, 91(3), 481-510. doi:Doi 10.1086/228311

Grant, R. M. (1991). The Resource-Based Theory of Competitive Advantage - Implications for Strategy Formulation. California Management Review, 33(3), 114-135.

Greif, A. (1989). Reputation and Coalitions in Medieval Trade - Evidence on the Maghribi Traders. Journal of Economic History, 49(4), 857-882. doi:10.2307/2122741

Grilo, I., \& Irigoyen, J.-M. (2006). Entrepreneurship in the EU: To Wish and not to be. Small business economics, 26(4), 305-318. doi:10.1007/s11187-005-1561-3 
Guba, E. G., \& Lincoln, Y. S. (1989). Fourth Generation Evaluation USA.: Sage Publications.

Guillen, M. F. (2000). Business Groups in Emerging Economies: A Resource-Based View. Academy of Management Journal, 43(3), 362-380. doi:Doi 10.2307/1556400

Guth, W. D., \& Ginsberg, A. (1990). Guest Editors' Introduction: Corporate Entrepreneurship. Strategic Management Journal, 11(Special Issue: Corporate Entrepreneurship), 5-15.

Hadley, R. D., \& Wilson, H. I. M. (2003). The Network Model of Internationalisation and Experiential Knowledge. International Business Review, 12(6), 697-717. doi:10.1016/j.ibusrev.2003.01.001

Hagen, B., Zucchella, A., Cerchiello, P., \& De Giovanni, N. (2012). International Strategy and Performance-Clustering Strategic Types of SMEs. International Business Review, 21(3), 369-382. doi:10.1016/j.ibusrev.2011.04.002

Hakansson, H. (1982). International Marketing and Purchasing of Industrial Goods: An Interaction Approach (First ed.): John Wiley \& Sons Inc.

Hakansson, H., \& Johanson, J. (1992). A Model of Industrial Networks. In B. Axelsson \& G. Easton (Eds.), Industrial Networks: A New View of Reality (pp. 28-34). London: Routledge.

Hakansson, H., \& Snehota, I. (1989). No Business is an Island: The Network Concept of Business Strategy. Scandinavian Journal of Management, 5(3), 187-200.

Halinen, A., \& Tomroos, J. A. (2005). Using Case Methods in the Study of Contemporary Business Networks. Journal of Business Research, 58(9), 1285-1297. doi:10.1016/j.jbusres.2004.02.001

Halinen, A., \& Törnroos, J. Å. (1998). The Role of Embeddedness in the Evolution of Business Networks. Scandinavian Journal of Management, 14(3), 187-205.

Hansen, J. D., Deitz, G. D., Tokman, M., Marino, L. D., \& Weaver, K. M. (2011). Cross-National Invariance of the Entrepreneurial Orientation Scale. Journal of Business Venturing, 26(1), 61-78. doi:10.1016/j.jbusvent.2009.05.003

Hansen, M. T. (1999). The Search-Transfer Problem: The Role of Weak Ties in Sharing Knowledge across Organization Subunits. Administrative science quarterly, 44(1), 82111. doi:Doi 10.2307/2667032

Hargadon, A., \& Sutton, R. I. (1997). Technology Brokering and Innovation in a Product Development Firm. Administrative science quarterly, 42(4), 716-749. doi:Doi $10.2307 / 2393655$

Harris, S., \& Wheeler, C. (2005). Entrepreneurs' Relationships for Internationalization: Functions, Origins and Strategies. International Business Review, 14(2), 187-207. doi:10.1016/j.ibusrev.2004.04.008

Hartsfield, S., Johansen, D., \& Knight, G. (2008). Entrepreneurial Orientation, Strategy and Marketing Capabilities in the Performance of Born Global Firms. International Business: Research, Teaching and Practice, 2(1), 12-38.

Hayton, J. C., Hornsby, J. S., \& Bloodgood, J. (2013). Part II: The Contribution of HRM to Corporate Entrepreneurship: A Review and Agenda for Future Research. M@n@gement, 16(4), 1357-1432. 
Heavey, C., \& Simsek, Z. (2013). Top Management Compositional Effects on Corporate Entrepreneurship: The Moderating Role of Perceived Technological Uncertainty. Journal of product innovation management, 30(5), 837-855. doi:10.1111/jpim.12033

Hitt, M. A., Ireland, R. D., Camp, S. M., \& Sexton, D. L. (2001). Guest Editors' Introduction to the special Issue - Strategic Entrepreneurship: Entrepreneurial Strategies for Wealth Creation. Strategic Management Journal, 22(6-7), 479-491. doi:DOI 10.1002/smj.196

Hofer, C. W., \& Schendel, D. (1978). Strategy Formulation: Analytical Concepts: West Group.

Holmlund, M., \& Kock, S. (1998). Relationships and the Internationalisation of Finnish Small and Medium-Sized Companies. International Small Business Journal, 16(4), 46-63.

Hornsby, J. S., Bloodgood, J. M., Hayton, J., \& Kuratko, D. F. (2013). Network Legitimacy Diffusion: A Model for Corporate Entrepreneurship. International Entrepreneurship and Management Journal, 9(3), 307-322. doi:10.1007/s11365-013-0256-5

Hosseini, M., \& Eskandari, F. (2013). Investigating Entrepreneurial Orientation and Firm Performance in the Iranian Agricultural Context. Journal of Agricultural Science and Technology, 15(2), 203-214.

House, R. J., Shane, S. A., \& Herold, D. M. (1996). Rumors of the Death of Dispositional Research are Vastly Exaggerated. Academy of management review, 21(1), 203-224.

Howell, R. D., Breivik, E., \& Wilcox, J. B. (2007). Reconsidering Formative Measurement. Psychological Methods, 12(2), 205-218. doi:10.1037/1082-989X.12.2.205

Hu, J., \& Stanton, J. (2011). A Study of How Mainland Chinese Small and Medium Privately Owned Businesses Engage in Networking. Industrial Marketing Management, 40(4), 534539. doi:10.1016/j.indmarman.2010.12.009

Hu, L. T., \& Bentler, P. M. (1998). Fit Indices in Covariance Structure Modeling: Sensitivity to Underparameterized Model Misspecification. Psychological Methods, 3(4), 424-453. doi:Doi 10.1037//1082-989x.3.4.424

Huang, K.-P., \& Wang, K. Y. (2011). The Moderating Effect Of Social Capital And Environmental Dynamism On The Link Between Entrepreneurial Orientation And Resource Acquisition. Quality \& Quantity, 47(3), 1617-1628. doi:10.1007/s11135-0119614-y

Huber, G. P., \& Power, D. J. (1985). Retrospective Reports of Strategic-Level Managers: Guidelines for Increasing Their Accuracy. Strategic Management Journal, 6(2), 171-180. doi:DOI 10.1002/smj.4250060206

Hughes, K. D. (2006). Exploring Motivation and Success Among Canadian Women Entrepreneurs. Journal of Small Business and Entrepreneurship, 19(2), 107-120.

Hughes, M., \& Morgan, R. E. (2007). Deconstructing the Relationship between Entrepreneurial Orientation and Business Performance at the Embryonic Stage of Firm Growth. Industrial Marketing Management, 36(5), 651-661. doi:10.1016/j.indmarman.2006.04.003

Hult, G. T. M., Hurley, R. F., \& Knight, G. A. (2004). Innovativeness: Its Antecedents and Impact on Business Performance. Industrial Marketing Management, 33(5), 429-438. doi:10.1016/j.indmarman.2003.08.015 
Hult, G. T. M., Snow, C. C., \& Kandemir, D. (2003). The Role of Entrepreneurship in Building Cultural Competitiveness in Different Organizational Types. Journal of Management, 29(3), 401-426. doi:10.1016/S0149-2063(03)00017-5

Hurley, R. F., \& Hult, G. T. M. (1998). Innovation, Market Orientation, and Organizational Learning: An Integration and EmpiricalExamination. Journal of Marketing, 62(3), 42-54.

Hurmerinta-PeltomÄki, L. (2003). Time and Internationalisation Theoretical Challenges Set by Rapid Internationalisation. Journal of International Entrepreneurship, 1(2), 217-236. doi:10.1023/a:1023856302314

Hymer, S. H. (1960). The International Operations of National Firms: A Study of Direct Foreign Investment. (Doctoral Thesis), Massachusetts Institute of Technology, Cambridge.

Ibeh, K., \& Kasem, L. (2011). The Network Perspective and the Internationalisation of Small and Medium-Sized Software Firms from Syria. Industrial Marketing Management, 40(3), 358-367. doi:10.1016/j.indmarman.2010.08.004

Ibeh, K. I. N. (2003). Toward a Contingency Framework of Export Entrepreneurship: Conceptualisations and Empirical Evidence. Small business economics, 20(1), 49-68. doi:Doi 10.1023/A:1020244404241

Ibeh, K. I. N. (2004). Furthering Export Participation in Less Performing Developing Countries. International Journal of Social Economics, 31(1/2), 94-110. doi:10.1108/03068290410515448

Ibeh, K. I. N., \& Young, S. (2001). Exporting as an Entrepreneurial Act: An Empirical Study of Nigerian Firms. European journal of marketing, 35(5/6), 566-586. doi:10.1108/03090560110388114

Inkpen, A. C., \& Currall, S. C. (2004). The Coevolution of Trust, Control, and Learning in Joint Ventures. Organization Science, 15(5), 586-599. doi:10.1287/orsc.1040.0079

Ireland, R. D., Covin, J. G., \& Kuratko, D. F. (2009). Conceptualizing Corporate Entrepreneurship Strategy. Entrepreneurship: Theory \& Practice, 33(1), 19-46. doi:10.1111/j.15406520.2008.00279.x

Ireland, R. D., Kuratko, D. F., \& Morris, M. H. (2006). A Health Audit for Corporate Entrepreneurship: Innovation at all Levels: Part II. Journal of Business Strategy, 27(2), 21-30. doi:10.1108/02756660610650019

Jalali, S. H. (2012). Environmental Determinants, Entrepreneurial Orientation and Export Performance: Empirical Evidence from Iran. Serbian Journal of Management, 7(2), 245255. doi:10.5937/sjm7-1687

Jambulingam, T., Kathuria, R., \& Doucette, W. R. (2005). Entrepreneurial Orientation as a Basis for Classification within a Service Industry: The Case of Retail Pharmacy Industry. Journal of Operations Management, 23(1), 23-42. doi:10.1016/j.jom.2004.09.003

Jantunen, A., Nummela, N., Puumalainen, K., \& Saarenketo, S. (2008). Strategic Orientations of Born Globals: Do They Really Matter? Journal of World Business, 43(2), 158-170. doi:10.1016/j.jwb.2007.11.015

Jantunen, A., Puumalainen, K., Saarenketo, S., \& Kyläheiko, K. (2005). Entrepreneurial Orientation, Dynamic Capabilities and International Performance. Journal of International Entrepreneurship, 3(3), 223-243. 
Jarvis, C. B., MacKenzie, S. B., \& Podsakoff, P. M. (2003). A Critical Review of Construct Indicators and Measurement Model Misspecification in Marketing and Consumer Research. Journal of Consumer Research, 30(2), 199-218. doi:10.1086/376806

Javalgi, R. G., \& Todd, P. R. (2011). Entrepreneurial Orientation, Management Commitment, and Human Capital: The Internationalization of SMEs in India. Journal of Business Research, 64(9), 1004-1010. doi:10.1016/j.jbusres.2010.11.024

Jennings, D. F., \& Lumpkin, J. R. (1989). Functioning Modeling Corporate Entrepreneurship: An Empirical Integrative Analysis. Journal of Management, 15(3), 485-502. doi:Doi $10.1177 / 014920638901500310$

Johanson, J., \& Mattsson, L. G. (1988). Internationalization in Industrial Systems: A Network Approach, Strategies in Global Competition. In N. Hood \& J. E. Vahlne (Eds.), Strategies in Global Competition: Selected Papers from the Prince Bertil Symposium at the Institute of International Business (pp. 287-314). Bristol, England.: Mackays of Chatham Ltd.

Johanson, J., \& Vahlne, J. E. (1977). The Internationalization Process of the Firm: A Model of Knowledge Development and Increasing Foreign Market Commitments. Journal of International Business Studies, 8(1), 23-32.

Johanson, J., \& Vahlne, J. E. (1990). The Mechanism of Internationalisation. International Marketing Review, 7(4), 1-67. doi:10.1108/02651339010137414

Johanson, J., \& Vahlne, J. E. (2006). Commitment and Opportunity Development in the Internationalization Process: A Note on the Uppsala Internationalization Process Model. Management International Review, 46(2), 165-178.

Johanson, J., \& Wiedersheim-Paul, F. (1975). The Internationalization of the Firm: Four Swedish Cases. Journal of Management Studies, 12(3), 305-322.

Jones, M. V. (1999). The Internationalization of Small High-Technology Firms. Journal of International Marketing, 7(4), 15-41.

Jones, M. V., \& Coviello, N. E. (2005). Internationalisation: Conceptualising an Entrepreneurial Process of Behaviour in Time. Journal of International Business Studies, 36(3), 284-303. doi:10.1057/palgrave.jibs.8400138

Kabiri, F., \& Salehi, M. (2013). Entrepreneurial Orientation in Exporter and Non-Exporter SMEs. Advances in Environmental Biology, 7(8), 1663-1669.

Katsikeas, C. S., \& Piercy, N. F. (1993). Long-Term Export Stimuli and Firm Characteristics in a European LDC. Journal of International Marketing, 1(3), 23-47.

Kautonen, T., \& Palmroos, J. (2009). The Impact of a Necessity-Based Start-Up on. Subsequent Entrepreneurial Satisfaction. International Entrepreneurship and Management Journal, 6(3), 285-300. doi:10.1007/s11365-008-0104-1

Kaya, N. (2006). The Impact of Human Resource Management Practices and Corporate Entrepreneurship on Firm Performance: Evidence from Turkish Firms. International Journal of Human Resource Management, 17(12), 2074-2090. doi:10.1080/09585190601000204

Kazem, A., \& van der Heijden, B. (2006). Exporting Firms' Strategic Choices: The Case of Egyptian SMEs in the Food Industry. SAM Advanced Management Journal, 71(3), 21-33. 
Kearney, C., Hisrich, R. D., \& Antoncic, B. (2013). The Mediating Role of Corporate Entrepreneurship for External Environment Effects on Performance. Journal of Business Economics and Management, 14(sup1), S328-S357. doi:10.3846/16111699.2012.720592

Keh, H. T., Nguyen, T. T. M., \& Ng, H. P. (2007). The Effects of Entrepreneurial Orientation and Marketing Information on the Performance of SMEs. Journal of Business Venturing, 22(4), 592-611. doi:10.1016/j.jbusvent.2006.05.003

Kelley, D. J., Peters, L., \& O'Connor, G. C. (2009). Intra-Organizational Networking for Innovation-Based Corporate Entrepreneurship. Journal of Business Venturing, 24(3), 221235. doi:10.1016/j.jbusvent.2008.05.010

Keupp, M. M., \& Gassmann, O. (2009). The Past and the Future of International Entrepreneurship: A Review and Suggestions for Developing the Field. Journal of Management, 35(3), 600633. doi: $10.1177 / 0149206308330558$

Khandwalla, P. N. (1972). Environment and Its Impact on the Organization. International Studies of Management \& Organization, 2(3), 297-313.

Khandwalla, P. N. (1977). Some Top Management Styles, Their Context and Performance. Organization and Administrative Sciences, 7(4), 21-51.

Khanna, T., \& Palepu, K. (2000). The Future of Business Groups in Emerging Markets: LongRun Evidence from Chile. Academy of Management Journal, 43(3), 268-285. doi:Doi $10.2307 / 1556395$

Kim, S., \& Skvoretz, J. (2013). Structural Embeddedness, Uncertainty, and International Trade. International Journal of Comparative Sociology, 54(2), 124-143. doi: $10.1177 / 0020715212469513$

Knight, G. A. (1997). Cross-Cultural Reliability and Validity of a Scale to Measure Firm Entrepreneurial Orientation. Journal of Business Venturing, 12(3), 213-225. doi:Doi 10.1016/S0883-9026(96)00065-1

Knight, G. A. (2000). Entrepreneurship and Marketing Strategy: The SME under Globalization. Journal of International Marketing, 8(2), 12-32. doi:DOI 10.1509/jimk.8.2.12.19620

Knight, G. A. (2001). Entrepreneurship and Strategy in the International SME. Journal of International Management, 7(3), 155-171.

Knight, G. A., \& Cavusgil, S. T. (2004). Innovation, Organizational Capabilities, and the BornGlobal Firm. Journal of International Business Studies, 35(2), 124-141. doi:10.1057/palgrave.jibs.8400071

Knight, G. A., \& Kim, D. (2008). International Business Competence and the Contemporary Firm. Journal of International Business Studies, 40(2), 255-273. doi:10.1057/palgrave.jibs.8400397

Kocak, A., \& Abimbola, T. (2009). The Effects of Entrepreneurial Marketing on Born Global Performance. International Marketing Review, 26(4-5), 439-452. doi:10.1108/02651330910971977

Komulainen, H., Mainela, T., \& Tähtinen, J. (2006). Social Networks in the Initiation of the High Tech Firm's Internationalization. International Journal of Entrepreneurship and Innovation Management, 6(6), 526-541. doi:10.1504/IJEIM.2006.010979 
Kraus, S. (2013). The Role of Entrepreneurial Orientation in Service Firms: Empirical Evidence from Austria. Service Industries Journal, 33(5), 427-444. doi: $10.1080 / 02642069.2011 .622373$

Kraus, S., Rigtering, J. P. C., Hughes, M., \& Hosman, V. (2011). Entrepreneurial Orientation and the Business Performance of SMEs: A Quantitative Study from the Netherlands. Review of Managerial Science, 6(2), 161-182. doi:10.1007/s11846-011-0062-9

Kreiser, P. M. (2005). Reconceptualizing Firm-Level Entrepreneurship. (Doctoral Thesis), The University of Alabama, USA.

Kreiser, P. M., Marino, L. D., Davis, J. L., Tang, Z., \& Lee, C. (2010). Firm-Level Entrepreneurship: The Role of Proactiveness, Innovativeness and Strategic Renewal in the Creation and Exploration of Opportunities. Journal of Developmental Entrepreneurship (JDE), 15(2), 143-163.

Kreiser, P. M., Marino, L. D., Kuratko, D. F., \& Weaver, K. M. (2012). Disaggregating Entrepreneurial Orientation: The Non-Linear Impact of Innovativeness, Proactiveness and Risk-Taking on SME Performance. Small business economics, 40(2), 273-291. doi:10.1007/s11187-012-9460-x

Kreiser, P. M., Marino, L. D., \& Weaver, K. M. (2002). Assessing the Psychometric Properties of the Entrepreneurial Orientation Scale: A Multi-Country Analysis. Entrepreneurship: Theory \& Practice, 26(4), 71-94.

Kropp, F., Lindsay, N. J., \& Shoham, A. (2006). Entrepreneurial, Market and Learning Orientations and International Entrepreneurial Business Venture Performance in South African Firms. International Marketing Review, 23(5), 504-523. doi:10.1108/02651330610703427

Kropp, F., Lindsay, N. J., \& Shoham, A. (2008). Entrepreneurial Orientation and International Entrepreneurial Business Venture Startup. International Journal of Entrepreneurial Behavior \& Research, 14(2), 102-117. doi:10.1108/13552550810863080

Kuivalainen, O., Sundqvist, S., Puumalainen, K., \& Cadogan, J. W. (2004). The Effect of Environmental Turbulence and Leader Characteristics on International Performance: Are Knowledge-Based Firms Different? Canadian Journal of Administrative Sciences/Revue Canadienne des Sciences de l'Administration, 21(1), 35-50.

Kuivalainen, O., Sundqvist, S., \& Servais, P. (2007). Firms' Degree of Born-Globalness, International Entrepreneurial Orientation and Export Performance. Journal of World Business, 42(3), 253-267. doi:10.1016/j.jwb.2007.04.010

Kumar, N. (2013). Internationalisation of Indian Knowledge-Intensive Service Firms: Learning as an Antecedent to Entrepreneurial Orientation. Asian Business \& Management, 12(5), 503523. doi:10.1057/abm.2013.20

Kuratko, D. F., \& Audretsch, D. B. (2013). Clarifying the Domains of Corporate Entrepreneurship. International Entrepreneurship and Management Journal, 9(3), 323-335. doi:10.1007/s11365-013-0257-4

Kuratko, D. F., Ireland, R. D., \& Hornsby, J. S. (2004). Corporate Entrepreneurship Behavior among Managers: A Review of Theory, Research and Practice. In J. A. Katz \& D. A. Shepherd (Eds.), Advances in Entrepreneurship, Firm Emergence and Growth (pp. 7-45). Oxford, UK.: Elsevier Publishing. 
Lages, L. F., Silva, G., \& Styles, C. (2009). Relationship Capabilities, Quality, and Innovation as Determinants of Export Performance. Journal of International Marketing, 17(4), 47-70. doi:10.1509/jimk.17.4.47

Lamont, B. T., Marlin, D., \& Hoffman, J. J. (1993). Porter's Generic Strategies, Discontinuous Environments, and Performance: A Longitudinal Study of Changing Strategies in the Hospital Industry. Health Serv Res, 28(5), 623-640.

Lan, Q., \& Wu, S. (2010). An Empirical Study of Entrepreneurial Orientation and Degree of Internationalization of Small and Medium Sized Chinese Manufacturing Enterprises. Journal of Chinese Entrepreneurship, 2(1), 53-75. doi:10.1108/17561391011019023

Law, K. S., Wong, C. S., \& Mobley, W. H. (1998). Toward a Taxonomy of Multidimensional Constructs. Academy of management review, 23(4), 741-755.

Lee, C., Lee, K., \& Pennings, J. M. (2001). Internal Capabilities, External Networks, and Performance: A Study on Technology-based Ventures. Strategic Management Journal, 22(6-7), 615-640. doi:DOI 10.1002/smj.181

Leonidou, L. C. (2004). An Analysis of the Barriers Hindering Small Business Export Development

Journal of Small Business Management, 42(3), 279-302. doi:DOI 10.1111/j.1540627X.2004.00112.x

Leonidou, L. C., \& Katsikeas, C. S. (1996). The Export Development Process: An Integrative Review of Empirical Models. Journal of International Business Studies, 27(3), 517-551.

Leonidou, L. C., Katsikeas, C. S., Palihawadana, D., \& Spyropoulou, S. (2007). An Analytical Review of the Factors Stimulating Smaller Firms to Export. International Marketing Review, 24(6), 735-770. doi:10.1108/02651330710832685

Li, H. Y., Zhang, Y., \& Chan, T. S. (2005). Entrepreneurial Strategy Making and Performance in China's New Technology Ventures: The Contingency Effect of Environments and Firm Competences. The Journal of High Technology Management Research, 16(1), 37-57. doi:10.1016/j.hitech.2005.06.003

Li, J. J., \& Zhou, K. Z. (2010). How Foreign Firms Achieve Competitive Advantage in the Chinese Emerging Economy: Managerial Ties and Market Orientation. Journal of Business Research, 63(8), 856-862. doi:10.1016/j.jbusres.2009.06.011

Li, Y. A., Wei, Z. L., \& Liu, Y. (2010). Strategic Orientations, Knowledge Acquisition, and Firm Performance: The Perspective of the Vendor in Cross-Border Outsourcing. Journal of Management Studies, 47(8), 1457-1482. doi:10.1111/j.1467-6486.2010.00949.x

Li, Y. H., Huang, J. W., \& Tsai, M. T. (2009). Entrepreneurial Orientation and Firm Performance: The Role of Knowledge Creation Process. Industrial Marketing Management, 38(4), 440449. doi:10.1016/j.indmarman.2008.02.004

Lisboa, A., Skarmeas, D., \& Lages, C. (2011). Entrepreneurial Orientation, Exploitative and Explorative Capabilities, and Performance Outcomes in Export Markets: A ResourceBased Approach. Industrial Marketing Management, 40(8), 1274-1284. doi:10.1016/j.indmarman.2011.10.013

Liu, Y., Li, Y., \& Xue, J. Q. (2011). Ownership, Strategic Orientation and Internationalization in Emerging Markets. Journal of World Business, 46(3), 381-393. doi:10.1016/j.jwb.2010.07.012 
Loane, S., \& Bell, J. (2006). Rapid Internationalisation among Entrepreneurial Firms in Australia, Canada, Ireland and New Zealand: An Extension to the Network Approach. International Marketing Review, 23(5), 467-485. doi:10.1108/02651330610703409

Lu, J. W., \& Beamish, P. W. (2001). The Internationalization and Performance of SMEs. Strategic Management Journal, 22(6-7), 565-586. doi:10.1002/smj.184

Lumpkin, G. T., \& Dess, G. G. (1996a). Clarifying the Entrepreneurial Orientation Construct and Linking It to Performance. Academy of management review, 21(1), 135-172. doi:Doi $10.2307 / 258632$

Lumpkin, G. T., \& Dess, G. G. (1996b). Enriching the Entrepreneurial Orientation Construct: A Reply to "Entrepreneurial Orientation or Pioneer Advantage". Academy of management review, 21(3), 605-607.

Lumpkin, G. T., \& Dess, G. G. (2001). Linking Two Dimensions of Entrepreneurial Orientation to Firm Performance: The Moderating Role of Environment and Industry Life Cycle. Journal of Business Venturing, 16(5), 429-451. doi:Doi 10.1016/S0883-9026(00)000483

Lumpkin, G. T., \& Erdogan, B. (1999). If Not Entrepreneurship, Can Psychological Characteristics Predict Entrepreneurial Orientation? - A Pilot Study. The ICFAI Journal of Entrepreneurship Development, 1(1), 21-33.

Luo, Y. D. (2003). Industrial Dynamics and Managerial Networking in An Emerging Market: The Case of China. Strategic Management Journal, 24(13), 1315-1327. doi:10.1002/smj.363

Lyon, D. W., Lumpkin, G. T., \& Dess, G. D. (2000). Enhancing Entrepreneurial Orientation Research: Operationalizing and Measuring a Key Strategic Decision Making Process. Journal of Management, 26(5), 1055-1085. doi:Doi 10.1177/014920630002600503

MacKenzie, S. B., Podsakoff, P. M., \& Jarvis, C. B. (2005). The Problem of Measurement Model Misspecification in Behavioral and Organizational Research and Some Recommended Solutions. Journal of Applied Psychology, 90(4), 710-730. doi:10.1037/00219010.90.4.710

MacKenzie, S. B., Podsakoff, P. M., \& Podsakoff, N. P. (2011). Construct Measurement and Validation Procedures in Mis and Behavioral Research: Integrating New and Existing Techniques. MIS Quarterly, 35(2), 293-334.

Madsen, T. K., \& Servais, P. (1997). The Internationalization of BornGlobals: an Evolutionary Process? International Business Review, 6(6), 561-583.

Majkgård, A., \& Sharma, D. D. (1998). Client-Following and Market-Seeking Strategies in the Internationalization of Service Firms. Journal of Business-to-Business Marketing, 4(3), 141. doi:10.1300/J033v04n03_01

March, J. G. (1991). Exploration and Exploitation in Organizational Learning. Organization Science, 2(1), 71-87. doi:10.1287/orsc.2.1.71

Matsuno, K., Mentzer, J. T., \& Ozsomer, A. (2002). The Effects of Entrepreneurial Proclivity and Market Orientation on Business Performance. Journal of Marketing, 66(3), 18-32. doi:DOI 10.1509/jmkg.66.3.18.18507

Mattsson, L. G. (2003). Reorganization of Distribution in Globalization of Markets: The Dynamic Context of Supply Chain Management Supply Chain Management-an International Journal, 8(5), 416-426. doi:10.1108/13598540310500259 
McAuley, A. (1999). Entrepreneurial Instant Exporters in the Scottish Arts and Crafts Sector. Journal of International Marketing, 7(4), 67-82.

Mcdougall, P. P. (1989). International Versus Domestic Entrepreneurship - New Venture Strategic Behavior and Industry Structure. Journal of Business Venturing, 4(6), 387-400. doi:Doi 10.1016/0883-9026(89)90009-8

McDougall, P. P., \& Oviatt, B. M. (2000). International Entrepreneurship: The Intersection of Two Research Paths. Academy of Management Journal, 43(5), 902-906. doi:Doi $10.2307 / 1556418$

McDougall, P. P., \& Oviatt, B. M. (2003). Some Fundamental Issues in International Entrepreneurship. United States Association for Small Business and Entrepreneurship. USA.

McDougall, P. P., Oviatt, B. M., \& Shrader, R. C. (2003). A Comparison of International and Domestic New Ventures. Journal of International Entrepreneurship, 1(1), 59-82.

Mcdougall, P. P., Shane, S., \& Oviatt, B. M. (1994). Explaining the Formation of International New Ventures - the Limits of Theories from International-Business Research. Journal of Business Venturing, 9(6), 469-487.

McGuinness, N. W., \& Little, B. (1981). The Influence of Product Characteristics on the Export Performance of New Industrial Products. Journal of Marketing, 45(2), 110-122.

McPherson, M., Smith-Lovin, L., \& Cook, J. M. (2001). Birds of a Feather: Homophily in Social Networks. Annual Review of Sociology, 27, 415-444. doi:DOI 10.1146/annurev.soc.27.1.415

Memili, E., Lumpkin, G. T., \& Dess, G. G. (2011). Entrepreneurial Orientation: The Driving Force for Corporate Entrepreneurship. In P. Mazzola \& F. W. Kellermanns (Eds.), Handbook of Research on Strategy Process (pp. 624): Edward Elgar Publishing.

Merriam, S. (1995). What Can You Tell From An N of 1?: Issues of Validity and Reliability in Qualitative Research. PAACE Journal of Lifelong Learning, 4, 50-60.

Messersmith, J. G., \& Wales, W. J. (2013). Entrepreneurial Orientation and Performance in Young Firms: the Role of Human Resource Management. International Small Business Journal, 31(2), 115-136. doi:10.1177/0266242611416141

Meyer, K., \& Skak, A. (2002). Networks, Serendipity and SME Entry into Eastern Europe. European Management Journal, 20(2), 179-188. doi:10.1016/s0263-2373(02)00028-2

Miles, M. P., \& Covin, J. G. (2002). Exploring the Practice of Corporate Venturing: Some Common Forms and TheirOrganizational Implications. Entrepreneurship: Theory \& Practice, 26(3), 21-40.

Miller, D. (1983). The Correlates of Entrepreneurship in Three Types of Firms. Management science, 29(7), 770-791.

Miller, D. (1988). Relating Porter Business Strategies to Environment and Structure - Analysis and Performance Implications. Academy of Management Journal, 31(2), 280-308. doi:Doi $10.2307 / 256549$

Miller, D. (2011). Miller (1983) Revisited: A Reflection on EO Research and Some Suggestions for the Future. Entrepreneurship Theory and Practice, 35(5), 873-894. doi:10.1111/j.1540-6520.2011.00457.x 
Miller, D., \& Friesen, P. H. (1982). Innovation in Conservative and Entrepreneurial Firms: Two Models of Strategic Momentum. Strategic Management Journal, 3(1), 1-25.

Miller, D., \& Friesen, P. H. (1983). Strategy-Making and Environment: The Third Link. Strategic Management Journal, 4(3), 221-235. doi:10.1002/smj.4250040304

Mintzberg, H. (1973). Strategy-Making in Three Modes. California Management Review, XVI(2), 44-53.

Mizruchi, M. S., \& Stearns, L. B. (2001). Getting Deals Done: The Use of Social Networks in Bank Decision-Making. American sociological review, 66(5), 647-671. doi:Doi $10.2307 / 3088952$

Moliterno, T. P., \& Mahony, D. M. (2011). Network Theory of Organization: A Multilevel Approach. Journal of Management, 37(2), 443-467. doi:10.1177/0149206310371692

Moore, C. S., \& Mueller, R. E. (2002). The Transition from Paid to Self-Employment in Canada : The Importance of Push Factors. Applied Economics, 34(6), 791-801. doi:10.1080/00036840110058473

Moreno, A. M., \& Casillas, J. C. (2008). Entrepreneurial Orientation and Growth of SMEs: A Causal Model. Entrepreneurship: Theory \& Practice, 32(3), 507-528.

Morgan, N. A., Vorhies, D. W., \& Mason, C. H. (2009). Market Orientation, Marketing Capabilities, and Firm Performance. Strategic Management Journal, 30(8), 909-920. doi:10.1002/smj.764

Morris, M., Kuratko, D., \& Covin, J. (2010). Corporate entrepreneurship \&amp; innovation (3e ed.): Cengage Learning.

Morris, M. H. (1998). Entrepreneurial Intensity : Sustaintable Advantages for Individuals, Organizations and Societies. USA: Quorum Books.

Morris, M. H., Kuratko, D. F., \& Covin, J. G. (2008). Corporate Entrepreneurship and Innovation: Entrepreneurial Development whithin Organizations (Second ed.). USA.: Cengage Learning.

Morris, M. H., Kuratko, D. F., \& Covin, J. G. (2011). Corporate entrepreneurship \&amp; innovation (3 ed.). Boston: Cengage/Suth-Western.

Morris, M. H., \& Sexton, D. L. (1996). The Concept of Entrepreneurial Intensity: Implications for Company Performance. Journal of Business Research, 36(1), 5-13. doi:Doi $10.1016 / 0148-2963(95) 00158-1$

Morris, M. H., Webb, J. W., \& Franklin, R. J. (2011). Understanding the Manifestation of Entrepreneurial Orientation in the Nonprofit Context. Entrepreneurship: Theory \& Practice, 35(5), 947-971. doi:10.1111/j.1540-6520.2011.00453.x

Morse, J. M., Barrett, M., Mayan, M., Olson, K., \& Spiers, J. (2008). Verification Strategies for Establishing Reliability and Validity in Qualitative Research. International journal of qualitative methods, 1(2), 13-22.

Moses, J., \& Knutsen, T. (2012). Ways of Knowing: Competing Methodologies in Social and Political Science (ssecond ed.). China: Palgrave Macmillan.

Mostafa, R. H. A., Wheeler, C., \& Jones, M. V. (2005). Entrepreneurial Orientation, Commitment to the Internet and Export Performance in Small and Medium Sized Exporting Firms. 
Journal of International Entrepreneurship, 3(4), 291-302. doi:10.1007/s10843-006-78579

Musteen, M., Francis, J., \& Datta, D. K. (2010). The Influence of International Networks on Internationalization Speed and Performance: A Study of Czech SMEs. Journal of World Business, 45(3), 197-205. doi:10.1016/j.jwb.2009.12.003

Nahapiet, J., \& Ghoshal, S. (1998). Social Capital, Intellectual Capital, and the Organizational Advantage. Academy of management review, 23(2), 242-266. doi:Doi 10.2307/259373

Naldi, L., Achtenhagen, L., \& Davidsson, P. (2015). International Corporate Entrepreneurship among SMEs: A Test of Stevenson's Notion of Entrepreneurial Management. Journal of Small Business Management, 53(3), 780-800. doi:10.1111/jsbm.12087

Naldi, L., Nordqvist, M., Sjoberg, K., \& Wiklund, J. (2007). Entrepreneurial Orientation, Risk Taking, and Performance in Family Firms. Family Business Review, 20(1), 33-47. doi:DOI 10.1111/j.1741-6248.2007.00082.x

Naman, J. L., \& Slevin, D. P. (1993). Entrepreneurship and the Concept of Fit - a Model and Empirical Tests. Strategic Management Journal, 14(2), 137-153. doi:DOI $10.1002 / \mathrm{smj} .4250140205$

Nummela, N. (2004). Is the globe becoming small or is the small becoming global? Globalization and internationalizing SMEs. In M. V. Jones \& P. Dimitratos (Eds.), Emergin Paradigmes in International Entrepreneurship (1 ed., pp. 128-151). USA.: Edward Elgar Publishing.

Nummela, N., Saarenketo, S., \& Puumalainen, K. (2004). A Global Mindset : A Prerequisite for Successful Internationalization? Canadian Journal of Administrative Sciences/Revue Canadienne des Sciences de l'Administration, 21(1), 51-64.

O'Cass, A., \& Weerawardena, J. (2009). Examining the Role of International Entrepreneurship, Innovation and International Market Performance in SME Internationalisation. European journal of marketing, 43(11/12), 1325-1348. doi:10.1108/03090560910989911

O'Grady, K. E., \& Medoff, D. R. (1988). Categorical Variables in Multiple Regression: Some Cautions. Multivariate Behavioral Research, 23(2), 243-260. doi:10.1207/s15327906mbr2302_7

Oh, H., Labianca, G., \& Chung, M. H. (2006). A Multilevel Model of Group Social Capital. Academy of management review, 31(3), 569-582. doi:10.5465/Amr.2006.21318918

Okpara, J. O. (2009). Entrepreneurial Orientation and Export Performance: Evidence from an Emerging Economy. International Review of Business Research Papers.

Olson, E. M., Walker, O. C., \& Ruekert, R. W. (1995). Organizing for Effective New Product Development - the Moderating Role of Product Innovativeness. Journal of Marketing, 59(1), 48-62. doi:Doi 10.2307/1252014

Orhan, M., \& Scott, D. (2001). Why Women Enter into Entrepreneurship: An Explanatory Model. Women in Management Review, 16(5), 232-247. doi:10.1108/09649420110395719

Ortiz de Urbina Criado, M., Montoro Sânchez, Â., \& Romero Martînez, A. M. (2011). Domestic and International Corporate Entrepreneurship through Alliances. Canadian Journal of Administrative Sciences/Revue Canadienne des Sciences de l\&apos;Administration, 28(3), 317-327. 
Oviatt, B. M., \& Mcdougall, P. P. (1994). Toward a Theory of International New Ventures. Journal of International Business Studies, 25(1), 45-64. doi:DOI 10.1057/palgrave.jibs. 8490193

Oviatt, B. M., \& McDougall, P. P. (2005a). Defining International Entrepreneurship and Modeling the Speed of Internationalization. Entrepreneurship: Theory \& Practice, 29(5), 537-553. doi:DOI 10.1111/j.1540-6520.2005.00097.x

Oviatt, B. M., \& McDougall, P. P. (2005b). The Internationalization of Entrepreneurship. Journal of International Business Studies, 36(1), 2-8. doi:10.1057/palgrave.jibs.8400119

Ozgen, E., \& Baron, R. A. (2007). Social Sources Of Information In Opportunity Recognition: Effects Of Mentors, Industry Networks, And Professional Forums. Journal of Business Venturing, 22(2), 174-192. doi:10.1016/j.jbusvent.2005.12.001

Park, S. H., \& Luo, Y. D. (2001). Guanxi and Organizational Dynamics: Organizational Networking in Chinese Firms. Strategic Management Journal, 22(5), 455-477. doi:DOI 10.1002/smj.167

Parkman, I., Holloway, S., \& Sebastiao, H. (2012). Creative Industries: Aligning Entrepreneurial Orientation and Innovation Capacity. Journal of Research in Marketing and Entrepreneurship, 14(1), 95-114.

Patel, P. C., \& D'Souza, R. R. (2009). Leveraging Entrepreneurial Orientation to Enhance SME Export Performance. An Office of Advocacy Working Paper. The United States Association for Small Business and Entrepreneurship (USASBE).

Pearce, J. A., Fritz, D. A., \& Davis, P. S. (2010). Entrepreneurial Orientation and the Performance of Religious Congregations as Predicted by Rational Choice Theory. Entrepreneurship: Theory \& Practice, 34(1), 219-248. doi:10.1111/j.1540-6520.2009.00315.x

Peng, M. W. (2001). The Resource Based View and International Business. Journal of Management, 27(6), 803-829. doi:Doi 10.1177/014920630102700611

Peng, M. W., \& Luo, Y. D. (2000). Managerial Ties and Firm Performance in a Transition Economy: The Nature of a Micro-Macro Link. Academy of Management Journal, 43(3), 486-501. doi:Doi 10.2307/1556406

Penrose, E. (1959). The Theory of the Growth of the Firm. New York: Oxford University Press.

Perez-Luno, A., Wiklund, J., \& Cabrera, R. V. (2011). The Dual Nature of Innovative Activity: How Entrepreneurial Orientation Influences Innovation Generation and Adoption. Journal of Business Venturing, 26(5), 555-571. doi:10.1016/j.jbusvent.2010.03.001

Peter, J. P. (1979). Reliability: A Review of Psychometric Basics and Recent Marketing Practices. Journal of marketing research, 16(1), 6-17.

Peterson, R. A., \& Berger, D. G. (1971). Entrepreneurship in Organizations: Evidence from the Popular Music Industry. Administrative science quarterly, 16(1), 97-106.

Peterson, R. A., \& Kim, Y. (2013). On the Relationship Between Coefficient Alpha and Composite Reliability. Journal of Applied Psychology, 98(1), 194-198. doi:10.1037/a0030767

Phan, P. H., Wright, M., Ucbasaran, D., \& Tan, W. L. (2009). Corporate Entrepreneurship: Current Research and Future Directions. Journal of Business Venturing, 24(3), 197-205. doi:10.1016/j.jbusvent.2009.01.007 
Pinchot, G. (1985). Intrapreneuring: Why You Don't Have to Leave the Corporation to Become an Entrepreneur (First ed.). New York: Harpercollins.

Pinchot, G. (1986). Intrapreneuring. New York: Harpercollins.

Pitt, L., van der Merwe, R., Berthon, P., Salehi-Sangari, E., \& Caruana, A. (2006). Global Alliance Networks: A Comparison of Biotech SMEs in Sweden and Australia. Industrial Marketing Management, 35(5), 600-610. doi:10.1016/j.indmarman.2005.04.009

Podsakoff, P. M., MacKenzie, S. B., Jeong-Yeon, L., \& Podsakoff, N. P. (2003). Common Method Biases in Behavioral Research: A Critical Review of the Literature and Recommended Remedies. Journal of Applied Psychology, 88(5), 879-903.

Podsakoff, P. M., \& Organ, D. W. (1986). Self-Reports in Organizational Research - Problems and Prospects. Journal of Management, 12(4), 531-544. doi:Doi $10.1177 / 014920638601200408$

Quian, G., \& Li, L. (2003). Profitability of Small- and Medium-Sized Enterprises in High-Tech Industries: The Case of the Biotechnology Industry. Strategic Management Journal, 24(9), 881-887. doi:10.1002/smj.344

Raisch, S., \& Birkinshaw, J. (2008). Organizational Ambidexterity: Antecedents, Outcomes, and Moderators. Journal of Management, 34(3), 375-409. doi:10.1177/0149206308316058

Rauch, A., Wiklund, J., Lumpkin, G., \& Frese, M. (2009). Entrepreneurial Orientation and Business Performance: An Assessment of Past Research and Suggestions for the Future. Entrepreneurship Theory and Practice, 33(3), 761-787. doi:10.1111/j.15406520.2009.00308.x

Reagans, R., \& Zuckerman, E. W. (2001). Networks, Diversity, and Productivity: The Social Capital of Corporate R\&D Teams. Organization Science, 12(4), 502-517. doi:10.1287/orsc.12.4.502.10637

Reid, S. D. (1981). The Decision-Maker and Export Entry and Expansion. Journal of International Business Studies, 12(2), 101-112. doi:DOI 10.1057/palgrave.jibs.8490581

Reuber, A. R., \& Fischer, E. (1997). The Influence of the Management Team's International Experience on the Internationalization Behaviors of SMEs. Journal of International Business Studies, 28(4), 807-825.

Rialp, A., \& Rialp, J. (2001). Conceptual Frameworks on SMEs' Internationalization: Past, Present, and Future Trends of Research. Advances in International Marketing, 11, 49-78. doi:10.1016/s1474-7979(01)11016-1

Rialp, A., Rialp, J., \& Knight, G. A. (2005). The Phenomenon of Early Internationalizing Firms: What Do We Know After a Decade (1993-2003) of Scientific Inquiry? International Business Review, 14(2), 147-166. doi:10.1016/j.ibusrev.2004.04.006

Rigtering, J. P. C., Kraus, S., Eggers, F., \& Jensen, S. H. (2013). A Comparative Analysis of the Entrepreneurial Orientation/Growth Relationship in Service Firms and Manufacturing Firms. The Service Industries Journal, 34(4), 275-294. doi:10.1080/02642069.2013.778978

Ripolles, M., Blesa, A., \& Monferrer, D. (2012). Factors Enhancing the Choice of Higher Resource Commitment Entry Modes in International New Ventures. International Business Review, 21(4), 648-666. doi:10.1016/j.ibusrev.2011.07.007 
Ripolles, M., Blesa, A., \& Roig, S. (2010). The Influence of Innovation Orientation on the Internationalisation of SMEs in the Service Sector. The Service Industries Journal, 30(5), 777-791. doi:10.1080/02642060802342679

Ripolles, M., Menguzzato, M., \& Sánchez, L. (2007). Entrepreneurial Orientation and International Commitment. Journal of International Entrepreneurship, 5(3-4), 65-83. doi:10.1007/s10843-007-0016-0

Roberts, P. W. (1999). Product Innovation, Product-Market Competition and Persistent Profitability in the U.S. Pharmaceutical Industry. Strategic Management Journal, 20(7), 655-670.

Robertson, C., \& Chetty, S. K. (2000). A Contingency-Based Approach to Understanding Export Performance. International Business Review, 9(2), 211-235.

Rosenbusch, N., Brinckmann, J., \& Bausch, A. (2011). Is Innovation Always Beneficial? A MetaAnalysis of the Relationship between Innovation and Performance in SMEs. Journal of Business Venturing, 26(4), 441-457. doi:10.1016/j.jbusvent.2009.12.002

Ruekert, R. W., Walker, O. C., \& Roering, K. J. (1985). The Organization of Marketing Activities: A Contingency Theory of Structure and Performance. Journal of Marketing, 49(1), 1325. doi:Doi 10.2307/1251172

Runyan, R. C., Droge, C., \& Swinney, J. L. (2008). Entrepreneurial Orientation versus Small Business Orientation: What Are Their Relationships to Firm Performance? Journal of Small Business Management, 46(4), 567-588.

Runyan, R. C., Ge, B., Dong, B., \& Swinney, J. L. (2012). Entrepreneurial Orientation in CrossCultural Research: Assessing Measurement Invariance in the Construct. Entrepreneurship: Theory \& Practice, 36(4), 819-836. doi:10.1111/j.15406520.2010.00436.x

Saeed, S., Yousafzai, S. Y., \& Engelen, A. (2014). On Cultural and Macroeconomic Contingencies of the Entrepreneurial Orientation-Performance Relationship. Entrepreneurship: Theory \& Practice, 38(2), 255-290. doi:10.1111/etap.12097

Samiee, S., Walters, P. G. P., \& DuBois, F. L. (1993). Exporting as an Innovative Behaviour: An Empirical Investigation. International Marketing Review, 10(3), 5-27. doi:10.1108/02651339310040625

Sapienza, H. J., Autio, E., George, G., \& Zahra, S. A. (2006). A Capabilities Perspective on the Effects of Early Internationalization on Firm Survival and Growth. Academy of management review, 31(4), 914-933.

Sapienza, H. J., De Clercq, D., \& Sandberg, W. R. (2005). Antecedents of International and domestic Learning Effort. Journal of Business Venturing, 20(4), 437-457. doi:10.1016/j.jbusvent.2004.03.001

Sarkar, M. B., Echambadi, R. A. J., \& Harrison, J. S. (2001). Alliance Entrepreneurship and Firm Market Performance. Strategic Management Journal, 22(6-7), 701-711. doi:DOI 10.1002/smj.179

Sathe, V. (1988). From Surface to Deep Corporate Entrepreneurship. Human Resource Management, 27(4), 389-411. doi:DOI 10.1002/hrm.3930270403

Schensul, J. J. (2008a). Methodology. In L. M. Given (Ed.), The SAGE Encyclopedia of Qualitative Research Methods (Vol. 2, pp. 516-521). USA: Sage Publication Inc. 
Schensul, J. J. (2008b). Methods. In L. M. Given (Ed.), The SAGE Encyclopedia of Qualitative Research Methods (Vol. 2, pp. 521-526). USA: SAGE Publication Inc.

Sciascia, S., \& Bettinelli, C. (2013). Part III: Corporate Entrepreneurship in Context: Corporate Entrepreneurship in Family: Businesses: past, present and future research.M@n@gement, 16(4), 357-432.

Seibert, S. E., Kraimer, M. L., \& Liden, R. C. (2001). A Social Capital Theory of Career Success. Academy of Management Journal, 44(2), 219-237. doi:10.2307/3069452

Serlin, R. C., \& Levin, J. R. (1985). Teaching How to Derive Directly Interpretable Coding Schemes for Multiple Regression Analysis. Journal of Educational Statistics, 10(3), 223238. doi: $10.2307 / 1164794$

Shah, S. K., \& Corley, K. G. (2006). Building Better Theory by Bridging the QuantitativeQualitative Divide. Journal of Management Studies, 43(8), 1821-1835. doi:DOI 10.1111/j.1467-6486.2006.00662.x

Shane, S., \& Venkataraman, S. (2000). The Promise of Entrepreneurship as a Field of Research. The Academy of Management Review, 25(1), 217-226.

Sharma, D. D., \& Blomstermo, A. (2003). The Internationalization Process of Born Globals: A Network View. International Business Review, 12(6), 739-753. doi:10.1016/j.ibusrev.2003.05.002

Sharma, P., \& Chrisman, J. J. (1999). Toward a Reconciliation of the Definitional Issues in the Field of Corporate Entrepreneurship. Entrepreneurship: Theory \& Practice, 23(3), 11-27.

Shoham, A., Evangelista, F., \& Albaum, G. (2002). Strategic Firm Type and Export Performance. International Marketing Review, 19(2-3), 236-258. doi:10.1108/02651330210430686

Short, J. C., Broberg, J. C., Cogliser, C. C., \& Brigham, K. H. (2010). Construct Validation Using Computer-Aided Text Analysis (CATA) An Illustration Using Entrepreneurial Orientation. Organizational Research Methods, 13(2), 320-347. doi:10.1177/1094428109335949

Simon, R., \& Galunic, C. (2004). More than Network Structure: How Knowledge Heterogeneity Influences Managerial Performance and Innovativeness. Strategic Management Journal, 25(6), 541-562. doi:10.2307/20142143

Simsek, Z., \& Heavey, C. (2011). The Mediating Role of Knowledge-Based Capital for Corporate Entrepreneurship Effects on Performance: A Study of Small- to Medium-Sized Firms. Strategic Entrepreneurship Journal, 5(1), 81-100. doi:10.1002/sej.108

Simsek, Z., Veiga, J. F., \& Lubatkin, M. H. (2007). The Impact of Managerial Environmental Perceptions on Corporate Entrepreneurship: Towards Understanding Discretionary Slack's Pivotal Role. Journal of Management Studies, 44(8), 1398-1424.

Slater, S. F., \& Narver, J. C. (2000). The Positive Effect of a Market Orientation on Business Profitability: A Balanced Replication. Journal of Business Research, 48(1), 69-73. doi:Doi 10.1016/S0148-2963(98)00077-0

Slevin, D. P., \& Terjesen, S. A. (2011). Entrepreneurial Orientation: Reviewing Three Papers and Implications for Further Theoretical and Methodological Development. Entrepreneurship: Theory \& Practice, 35(5), 973-987. doi:10.1111/j.15406520.2011.00483.x 
Smart, D. T., \& Conant, J. S. (1994). Entrepreneurial Orientation, Distinctive Marketing Competencies and Organizational Performance. Journal of Applied Business Research (JABR), 10(3), 28-38.

Spence, M., \& Crick, D. (2006). A Comparative Investigation into the Internationalization of Canadian and UK High-Tech SMEs. International Marketing Review, 23(5), 524-548. doi:10.1108/02651330610703436

Stam, W., \& Elfring, T. (2008). Entrepreneurial Orientation and New Venture Performance: The Moderating Role of Intra- and Extra-Industry Social Capital. Academy of Management Journal, 51(1), 97-111.

Stevens, J. P. (2009). Applied Multivariate Statistics for the Social Sciences (5th ed. Vol. USA.): Routledge.

Stevenson, H. H., \& Jarillo, J. C. (1990). A Paradigm of Entrepreneurship - Entrepreneurial Management. Strategic Management Journal, 11(5), 17-27.

Stevenson, H. H., \& Jarrillo-Mossi, J. C. (1986). Preserving Entrepreneurship as Companies Grow. Journal of Business Strategy, 7(1), 10-23.

Stopford, J. M., \& Badenfuller, C. W. F. (1994). Creating Corporate Entrepreneurship. Strategic Management Journal, 15(7), 521-536. doi:DOI 10.1002/smj.4250150703

Styles, C., \& Ambler, T. (1994). Successful Export Practice. International Marketing Review, 11(6), 23-47. doi:10.1108/02651339410072999

Su, Z., Xie, E., \& Li, Y. (2011). Entrepreneurial Orientation and Firm Performance in New Ventures and Established Firms. Journal of Small Business Management, 49(4), 558-577. doi:10.1111/j.1540-627X.2011.00336.x

Su, Z., Xie, E., \& Wang, D. (2015). Entrepreneurial Orientation, Managerial Networking, and New Venture Performance in China. Journal of Small Business Management, 53(1), 228248. doi:10.1111/jsbm.12069

Sullivan, D. (1994). Measuring the Degree of Internationalization of a Firm. Journal of International Business Studies, 25(2), 325-342. doi:DOI 10.1057/palgrave.jibs.8490203

Sullivan, D. (1996). Measuring the Degree of Internationalization of a Firm: A Reply. Journal of International Business Studies, 27(1), 179-192. doi:DOI 10.1057/palgrave.jibs.8490132

Sundqvist, S., Kylaheiko, K., Kuivalainen, O., \& Cadogan, J. W. (2012). Kirznerian and Schumpeterian Entrepreneurial-Oriented Behavior in Turbulent Export Markets. International Marketing Review, 29(2), 203-219. doi:10.1108/02651331211216989

Svejenova, S. (2006). How Much Does Trust Really Matter? Some Reflections on the Significance and Implications of Madhok's Trust-Based Approach. Journal of International Business Studies, 37(1), 12-20. doi:10.2307/3875211

Talebi, K., Tajeddin, M., Rastgar, A. A., \& Emami, A. (2012). Internationalization of SMEs and Organizational Factors in a Developing Country: A Case Study of ICT Industry of Iran. International Journal of Academic Research in Business and Social Sciences, 2(12), 8096.

Talke, K., Salomo, S., \& Kock, A. (2011). Top Management Team Diversity and Strategic Innovation Orientation: The Relationship and Consequences for Innovativeness and 
Performance. Journal of product innovation management, 28(6), 819-832. doi:10.1111/j.1540-5885.2011.00851.x

Tang, J., Tang, Z., Marino, L. D., Zhang, Y., \& Li, Q. (2008). Exploring an Inverted U-Shape Relationship between Entrepreneurial Orientation and Performance in Chinese Ventures. Entrepreneurship: Theory \& Practice, 32(1), 219-239.

Teng, B. S. (2007). Corporate Entrepreneurship Activities through Strategic Alliances: A Resource-Based Approach toward Competitive Advantage. Journal of Management Studies, 44(1), 119-142. doi:10.1111/j.1467-6486.2006.00645.x

Terziovski, M. (2010). Innovation Practice and Its Performance Implications in Small and Medium Enterprises (SMEs) in the Manufacturing Sector: A Resource-Based View. Strategic Management Journal, 31(8), 892-902. doi:10.1002/smj.841

Tesfom, G., \& Lutz, C. (2006). A Classification of Export Marketing Problems of Small and Medium Sized Manufacturing Firms in Developing Countries. International Journal of Emerging Markets, 1(3), 262-281. doi:10.1108/17468800610674480

Thorgren, S., Wincent, J., \& Eriksson, J. (2011). Too small or Too Large to Trust Your Partners in Multipartner Alliances? The Role of Effort in Initiating Generalized Exchanges. Scandinavian Journal of Management, 27(1), 99-112. doi:10.1016/j.scaman.2010.11.001

Tikkanen, H. (1998). The Network Approach in Analyzing International Marketing and Purchasing Operations: A Case Study of a European SME's Focal Net 1992-95. Journal of Business \& Industrial Marketing, 13(2), 109-131. doi:10.1108/08858629810213333

Törnroos, J. Å., Freeman, S., Medlin, C. J., \& Akademi, Å. (2012). A time-space network approach to corporate internationalization. A theoretical reconceptualization. Paper presented at the IMP Annual Conference, Rome.

UNIDO. (2003). Strategy Document to Enhance the Contribution of an Efficient and Competitive Small and Medium-Sized Enterprise Sector to Industrial and Economic Development in the Islamic Republic of Iran.

Urbano, D., \& Turró, A. (2013). Conditioning Factors for Corporate Entrepreneurship: An In(ex)ternal Approach. International Entrepreneurship and Management Journal, 9(3), 379-396. doi:10.1007/s11365-013-0261-8

Vahlne, J. E., Ivarsson, I., \& Johanson, J. (2011). The Tortuous Road to Globalization for Volvo's Heavy Truck Business: Extending the Scope of the Uppsala Model. International Business Review, 20(1), 1-14.

Veflen Olsen, N., \& Sallis, J. (2006). Market Scanning for New Service Development. European journal of marketing, 40(5/6), 466-484. doi:10.1108/03090560610657796

Venkataraman, S. (1997). The Distinctive Domain of Entrepreneurship Research. In J. Katz \& R. Brockhaus (Eds.), Advances in Entrepreneurship, Firm Emergence, and Growth (Vol. 3, pp. 119-138). Bingley, UK.: Emerald Group Publishing Limited.

Venkatraman, N. (1989a). The Concept of Fit in Strategy Research: Toward Verbal and Statistical Correspondence. Academy of management review, 14(3), 423-444. doi:10.5465/AMR.1989.4279078

Venkatraman, N. (1989b). Strategic Orientation of Business Enterprises: The Construct, Dimensionality, and Measurement. Management science, 35(8), 942-962. doi:DOI 10.1287/mnsc.35.8.942 
Venkatraman, N., \& Grant, J. H. (1986). Construct Measurement in Organizational Strategy Research: A Critique and Proposal. Academy of management review, 11(1), 71-87. doi:Doi 10.2307/258332

Venkatraman, N., \& Prescott, J. E. (1990). Environment Strategy Coalignmentn: An EmpiricalTest of Its Performance Implications. Strategic Management Journal, 11(1), 1-23. doi:DOI 10.1002/smj.4250110102

Vernon, R. (1966). International Investment and International Trade in the Product Life Cycle. Quarterly Journalof Economics, 80(2), 190-207.

Vesper, K. H. (1990). New Venture Strategies (Second (Revised) ed.): Prentice Hall College Div.

Vora, D., Vora, J., \& Polley, D. (2012). Applying Entrepreneurial Orientation to a Medium Sized Firm. International Journal of Entrepreneurial Behavior \& Research, 18(3), 352-379. doi:10.1108/13552551211227738

Wakkee, I. (2007). Mapping Network Development of International New Ventures with the Use of Company E-mails. Journal of International Entrepreneurship, 4(4), 191-208. doi:10.1007/s10843-007-0008-0

Wales, W. J., Gupta, V. K., \& Mousa, F. T. (2011). Empirical Research on Entrepreneurial Orientation: An Assessment and Suggestions for Future Research. International Small Business Journal, 31(4), 357-383. doi:10.1177/0266242611418261

Wales, W. J., Patel, P. C., Parida, V., \& Kreiser, P. M. (2013). Nonlinear Effects of Entrepreneurial Orientation on Small Firm Performance: The Moderating Role of Resource Orchestration Capabilities. Strategic Entrepreneurship Journal, 7(2), 93-121. doi:10.1002/sej.1153

Wall, T. D., Michie, J., Patterson, M., Wood, S. J., Sheehan, M., Clegg, C. W., \& West, M. (2004). On the Validity of Subjective Measures of Company Performance. Personnel Psychology, 57(1), 95-118. doi:DOI 10.1111/j.1744-6570.2004.tb02485.x

Walter, A., Auer, M., \& Ritter, T. (2006). The Impact of Network Capabilities and Entrepreneurial Orientation on University Spin-Off Performance. Journal of Business Venturing, 21(4), 541-567. doi:10.1016/j.jbusvent.2005.02.005

Walters, P. G. P., \& Samiee, S. (1990). A Model for Assessing Performance in Small U.S. Exporting Firms. Entrepreneurship: Theory \& Practice, 15(2), 33-50.

Waltz, K. N. (1979). Theory of International Politics. New York.: McGraw-Hill.

Wasserman, S., \& Faust, K. (1994). Social Network Analysis: Methods and Applications. USA.: Cambridge University Press.

Weerawardena, J., Mort, G. S., Liesch, P. W., \& Knight, G. (2007). Conceptualizing Accelerated Internationalization in the Born Global Firm: A Dynamic Capabilities Perspective. Journal of World Business, 42(3), 294-306. doi:10.1016/j.jwb.2007.04.004

Welch, L. S., \& Luostarinen, R. (1988). Internationalization: Evolution of a Concept. Journal of General Management, 14(2), 34-56.

Wiklund, J. (1998). Small Firm Growth and Performance: Entrepreneurship and Beyond. (Doctoral thesis), Jönköping International Business School, Jönköping, Sweden.

Wiklund, J. (1999). The Sustainability of the Entrepreneurial Orientation: Performance Relationship. Entrepreneurship: Theory \& Practice, 24(1). 
Wiklund, J., \& Shepherd, D. (2003). Knowledge-Based Resources, Entrepreneurial Orientation, and the Performance of Small and Medium Sized Businesses. Strategic Management Journal, 24(13), 1307-1314. doi:10.1002/smj.360

Wiklund, J., \& Shepherd, D. (2005). Entrepreneurial Orientation and Small Business Performance: A Configurational Approach. Journal of Business Venturing, 20(1), 71-91. doi:10.1016/j.jbusvent.2004.01.001

Wiklund, J., \& Shepherd, D. (2011). Where to From Here? EO-as-Experimentation, Failure, and Distribution of Outcomes. Entrepreneurship: Theory \& Practice, 35(5), 925-946. doi:10.1111/j.1540-6520.2011.00454.x

Wymenga, P., Spanikova, V., Derbyshire, J., \& Barker, A. (2011). Are EU SMEs Recovering from the crisis? Annual Report on EU Small and Medium Sized Enterprises.

Xiao, Z., \& Tsui, A. S. (2007). When Brokers May Not Work: The Cultural Contingency of Social Capital in Chinese High-Tech Firms. Administrative science quarterly, 52(1), 1-31. doi:10.2307/20109901

Yamakawa, Y., Peng, M. W., \& Deeds, D. L. (2008). What Drives New Ventures to Internationalize from Emerging to Developed Economies? Entrepreneurship: Theory \& Practice, 32(1), 59-82. doi:10.1111/j.1540-6520.2007.00216.x

Yang, L., Arens, A. K., \& Watkins, D. A. (2014). Testing the Twofold Multidimensionality of Academic Self-Concept: A Study with Chinese Vocational Students. Educational Psychology, 1-19. doi:10.1080/01443410.2014.995597

Yang, Y., Wang, Q., Zhu, H., \& Wu, G. (2012). What Are the Effective Strategic Orientations for New Product Success under Different Environments? An Empirical Study of Chinese Businesses. Journal of product innovation management, 29(2), 166-179. doi:10.1111/j.1540-5885.2011.00900.x

Yeoh, P. L. (2004). 'International Learning: Antecedents and Performance Implications among Newly Internationalizing Companies in an Exporting Context. International Marketing Review, 21(4-5), 511-535. doi:10.1108/02651330410547171

Yeoh, P. L., \& Jeong, I. (1995). Contingency Relationships between Entrepreneurship, Export Channel Structure and Environment. A Proposed Conceptual Model of Export Performance. European journal of marketing, 29(8), 95-115. doi:10.1108/03090569510097574

Yin, R. K. (1994). Discovering the Future of the Case-Study Method in Evaluation Research. Evaluation Practice, 15(3), 283-290. doi:Doi 10.1016/0886-1633(94)90023-X

Yin, R. K. (2003). Case Study Research: Design and Methods (3 ed. Vol. 5). USA.: SAGE Publications.

Yiu, D., Bruton, G. D., \& Lu, Y. (2005). Understanding Business Group Performance in an Emerging Economy: Acquiring Resources and Capabilities in Order to Prosper. Journal of Management Studies, 42(1), 183-206. doi:DOI 10.1111/j.1467-6486.2005.00493.x

Yiu, D. W., Lau, C. M., \& Bruton, G. D. (2007). International Venturing by Emerging Economy Firms: The Effects of Firm Capabilities, Home Country Networks, and Corporate Entrepreneurship. Journal of International Business Studies, 38(4), 519-540. doi:10.1057/palgrave.jibs.8400278 
Yli-Renko, H., Autio, E., \& Tontti, V. (2002). Social Capital, Knowledge, and the International Growth of Technology-Based New Firms. International Business Review, 11(3), 279-304.

Young, S., Dimitratos, P., \& Dana, L. P. (2003). International Entrepreneurship Research: What Scope for International Business Theories? Journal of International Entrepreneurship, $1(1), 31-42$.

Yu, J. F., Gilbert, B. A., \& Oviatt, B. M. (2011). Effects of Alliances, Time, and Network Cohesion on the Initiation of Foreign Sales by New Ventures. Strategic Management Journal, 32(4), 424-446. doi:10.1002/smj.884

Zaheer, A., \& Bell, G. G. (2005). Benefiting from Network Position: Firm Capabilities, Structural Holes, and Performance. Strategic Management Journal, 26(9), 809-825. doi:10.1002/smj.482

Zaheer, A., \& Venkatraman, N. (1995). Relational Governance as an Interorganizational Strategy - an Empirical-Test of the Role of Trust in Economic Exchange. Strategic Management Journal, 16(5), 373-392. doi:DOI 10.1002/smj.4250160504

Zahra, S. A. (1991). Predictors and Financial Outcomes of Corporate Entrepreneurship: An Exploratory-Study. Journal of Business Venturing, 6(4), 259-285. doi:Doi 10.1016/08839026(91)90019-A

Zahra, S. A. (1993a). A Conceptual Model of Entrepreneurship as Firm Behavior; A Critique and Extension. Entrepreneurship: Theory \& Practice, 17(4), 5-21.

Zahra, S. A. (1993b). Environment, Corporate Entrepreneurship, and Financial Performance - a Taxonomic Approach. Journal of Business Venturing, 8(4), 319-340. doi:Doi 10.1016/0883-9026(93)90003-N

Zahra, S. A. (1995). Corporate Entrepreneurship and Financial Performance - the Case of Management Leveraged Buyouts. Journal of Business Venturing, 10(3), 225-247. doi:Doi 10.1016/0883-9026(94)00024-O

Zahra, S. A. (1996a). Goverance, Ownership, and Corporate Entrepreneurship: The Moderating Impact of Industry Technological OpportunitiesAuthor. Academy of Management Journal, 39(6), 1713-1735.

Zahra, S. A. (1996b). Technology Strategy and Financial Performance: Examining the Moderating Role of the Firm's Competitive Environment. Journal of Business Venturing, 11(3), 189219.

Zahra, S. A. (2005). A Theory of International New Ventures: A Decade of Research. Journal of International Business Studies, 36(1), 20-28. doi:10.1057/palgrave.jibs.8400118

Zahra, S. A., \& Bogner, W. C. (2000). Technology Strategy and Software New Ventures' Performance: Exploring the Moderating Effect of the Competitive Environment. Journal of Business Venturing, 15(2), 135-173. doi:Doi 10.1016/S0883-9026(98)00009-3

Zahra, S. A., \& Covin, J. G. (1995). Contextual Influences on the Corporate Entrepreneurship Performance Relationship - a Longitudinal Analysis. Journal of Business Venturing, 10(1), 43-58. doi:Doi 10.1016/0883-9026(94)00004-E

Zahra, S. A., \& Garvis, D. M. (2000). International Corporate Entrepreneurship and Firm Performance: The Moderating Effect of International Environmental Hostility. Journal of Business Venturing, 15(5-6), 469-492. doi:Doi 10.1016/S0883-9026(99)00036-1 
Zahra, S. A., \& George, G. (2002). International Entrepreneurship: The Current Status of the Field and Future Research Agenda. In M. A. Hitt, R. D. Ireland, S. M. Camp, \& D. L. Sexton (Eds.), Strategic entrepreneurship: Creating a new mindset (pp. 255-288). London, UK.: Wiley-Blackwell.

Zahra, S. A., Hayton, J., Marcel, J., \& O'Neill, H. (2001). Fostering Entrepreneurship During International Expansion: Managing Key Challenges. European Management Journal, 19(4), 359-369.

Zahra, S. A., \& Hayton, J. C. (2008). The Effect of International Venturing on Firm Performance: The Moderating Influence of Absorptive Capacity. Journal of Business Venturing, 23(2), 195-220. doi:10.1016/j.jbusvent.2007.01.001

Zahra, S. A., Ireland, R. D., \& Hitt, M. A. (2000). International Expansion by New Venture Firms: International Diversity, Mode of Market Entry, Technological Learning, and Performance. Academy of Management Journal, 43(5), 925-950. doi:Doi $10.2307 / 1556420$

Zahra, S. A., Jennings, D. F., \& Kuratko, D. F. (1999). The Antecedents and Consequences of Firm-Level Entrepreneurship: The State of the Field. Entrepreneurship: Theory \& Practice, 24(2), 45-66.

Zahra, S. A., Matherne, B. P., \& Carleton, J. M. (2003). Technological Resource Leveraging and the Internationalisation of New Ventures. Journal of International Entrepreneurship, 1(2), 163-186.

Zahra, S. A., Neck, H. M., \& Kelley, D. J. (2004). International Corporate Entrepreneurship and the Evolution of Organizational Competence : A Knowledge-Based Perspective. In J. A. Katz \& D. A. Shepherd (Eds.), Advances in Entrepreneurship, Firm Emergence and Growth (Vol. 7, pp. 145-171): Emerald Group Publishing Limited.

Zahra, S. A., Neubaum, D. O., \& Huse, M. (1997). The Effect of the Environment on Export Performance Among Telecommunications New Ventures. Entrepreneurship: Theory \& Practice, 22(1), 25-46.

Zahra, S. A., Neubaum, D. O., \& Huse, M. (2000). Entrepreneurship in Medium-Size Companies: Exploring the Effects of Ownership and Governance Systems. Journal of Management, 26(5), 947-976. doi:Doi 10.1177/014920630002600509

Zahra, S. A., Randerson, K., \& Fayolle, A. (2013a). Corporate Entrepreneurship: Where Are We? Where Can We Go from Here? M@n@gement, 16(4), 357-432.

Zahra, S. A., Randerson, K., \& Fayolle, A. (2013b). Part I: The Evolution and Contributions of Corporate Entrepreneurship Research.M@n@gement,16(3),357-432.

Zain, M., \& Ng, S. I. (2006). The Impacts of Network Relationships on SMEs' Internationalization Process. Thunderbird International Business Review, 48(2), 183-205. doi:10.1002/tie.20092

Zhang, M., Sarker, S., \& Sarker, S. (2013). Drivers and Export Performance Impacts of IT Capability in 'Born-Global' Firms: A Cross-National Study. Information Systems Journal, 23(5), 419-443. doi:10.1111/j.1365-2575.2012.00404.x

Zhang, M., Tansuhaj, P., \& McCullough, J. (2009). International Entrepreneurial Capability: The Measurement and a Comparison between Born Global Firms and Traditional Exporters in 
China. Journal of International Entrepreneurship, 7(4), 292-322. doi:10.1007/s10843009-0042-1

Zhang, X., Ma, X., \& Wang, Y. (2012). Entrepreneurial Orientation, Social Capital, and the Internationalization of SMEs: Evidence From China. Thunderbird International Business Review, 54(2), 195-210. doi:10.1002/tie.21451

Zhou, L. (2007). The Effects of Entrepreneurial Proclivity and Foreign Market Knowledge on Early Internationalization. Journal of World Business, 42(3), 281-293. doi:10.1016/j.jwb.2007.04.009

Zhou, L., Barnes, B. R., \& Lu, Y. (2009). Entrepreneurial Proclivity, Capability Upgrading and Performance Advantage of Newness among International New Ventures. Journal of International Business Studies, 41(5), 882-905. doi:10.1057/jibs.2009.87

Zhou, L. X., Wu, W. P., \& Luo, X. M. (2007). Internationalization and the Performance of BornGlobal SMEs: The Mediating Role of Social Networks. Journal of International Business Studies, 38(4), 673-690. doi:10.1057/palgrave.jibs.8400282

Zhou, M. (2011). Intensification of Geo-Cultural Homophily in Global Trade: Evidence From the Gravity Model. Social Science Research, 40(1), 193-209. doi:10.1016/j.ssresearch.2010.07.002

Zohari, T. (2008). Iranian Government Globalization Policy Impacts on SMEs and the Corresponding Effect on Iranian-Swedish Trade. Stockholm University. Sweden. 
andomatirs 


\section{Survey Questionnaire (Persian Version)}

با سلام

در جامعه جعاني امروز، بين المللي شدن كسب و كارهاي كوتجك و متوسط اجتناب نايذير

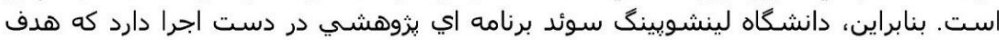

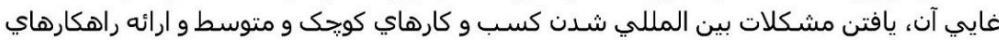

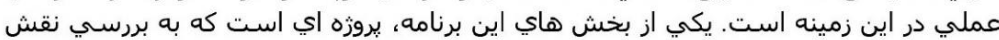

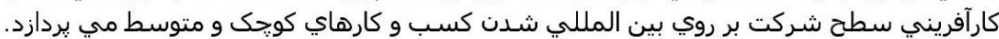

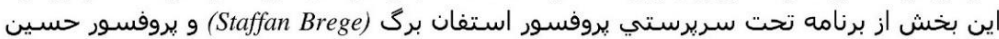

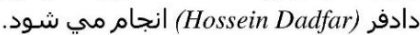

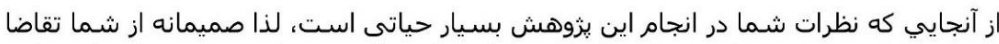

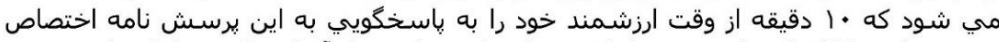

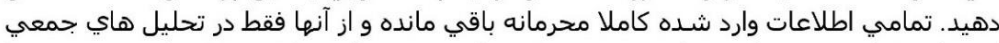

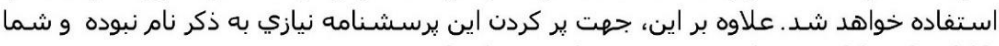

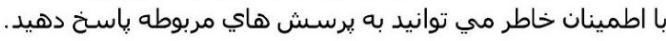

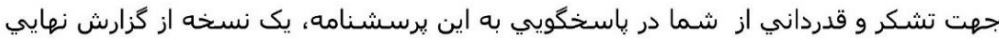

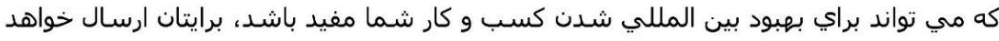

قبلا از همكاري شما صميمانه سبياسكذارم حسئي

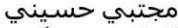

دانشجوي دكتري دانشكّاه لينشويينگ - سوئد 


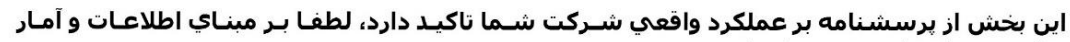 واقعي شركت اين بخش بش را بر كنيد. \\ تعداد كارمندان: \\ تعداد كشورهايي كa محصولات شما را مي خرند: \\ تعداد سالبايي كه در خارج درس خوانده يا كار كرده ايد: \\ سال تاسيس شركت: \\ تاريخ اولين فروش خارجي: \\ نسبت فروش خارجي به فروش كل:}

طي سه سال كذشته .....

\begin{tabular}{|c|c|c|c|c|c|c|c|}
\hline \multicolumn{4}{|c|}{ كاملا موافق } & \multicolumn{3}{|c|}{ كاملا ناموافق } & \multirow[b]{2}{*}{ ما بِيشرو توسعه نوآوري هاي تاثيرگذار در صنعت بوده ايم. } \\
\hline 7 & 6 & 5 & 4 & 3 & 2 & 1 & \\
\hline 7 & 6 & 5 & 4 & 3 & 2 & 1 & 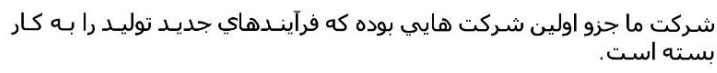 \\
\hline 7 & 6 & 5 & 4 & 3 & 2 & 1 & مهره برداري قرار داده استـت بـتين بوده ايم كه بازارهاي جديد را كشف كرده و مـورد \\
\hline 7 & 6 & 5 & 4 & 3 & 2 & 1 & شركت ما در زمينه نوآوري محصول و نوآوري فرآيند توليد، بيشتاز بوده است. \\
\hline 7 & 6 & 5 & 4 & 3 & 2 & 1 & ما تعداد زيادي محصولات و خدمات جديد به بازار معرفي كرده ايم. \\
\hline 7 & 6 & 5 & 4 & 3 & 2 & 1 & شركت ما وارد جندين صنعت جديد شـده است. \\
\hline 7 & 6 & 5 & 4 & 3 & 2 & 1 & ما فعاليت هاي بين المللي خود را به نحو جشمكيري توسعه داده ايم . \\
\hline 7 & 6 & 5 & 4 & 3 & 2 & 1 & ما شركت هاي جديدي را در صنايع مختلف خريداري كرده ايم. \\
\hline 7 & 6 & 5 & 4 & 3 & 2 & 1 & سازمان ما خطوط توليدي/خدماتي جديدي را خلق نموده است. \\
\hline 7 & 6 & 5 & 4 & 3 & 2 & 1 & سموده اسـت. ــــب و كارهـاي مخـاطره يـذير جديـدي را حمايـت و يـا تاسـيس \\
\hline 7 & 6 & 5 & 4 & 3 & 2 & I & كرده ايم. ورود به صنايع جديد، بر بهبود عملكرد كنوني كسب و كار خـود تمركز \\
\hline 7 & 6 & 5 & 4 & 3 & 2 & 1 & ما تعدادي از واحدهاي غيرسودآور را فروخته ايم. \\
\hline 7 & 6 & 5 & 4 & 3 & 2 & 1 & سازمان ما، استراتزي هاي واحدهاي سازماني خود را تغيير داده است. \\
\hline 7 & 6 & 5 & 4 & 3 & 2 & 1 & ما جندين برنامه براي بعبود بهره وري واحدهاي خود معرفي كرده ايم. \\
\hline 7 & 6 & 5 & 4 & 3 & 2 & 1 & 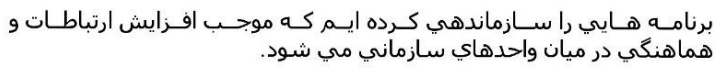 \\
\hline 7 & 6 & 5 & 4 & 3 & 2 & 1 & ســــــان مـا مجموعـه فعاليـت هـاي درون واحـدها را مـورد بـازبيني قـرار داده \\
\hline
\end{tabular}




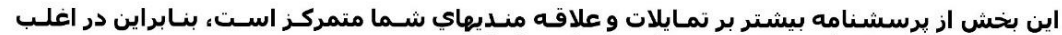

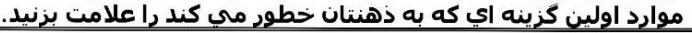
به طور كلي، مديران ارشد شركت ما (شامل خودنان) ... موانه

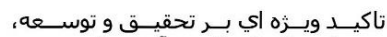
ييشتاري تكنولوزيك و نوآوري دارئد $\begin{array}{lllllllllll}7 & 6 & 5 & 4 & 3 & 2 & 1 & \end{array}$

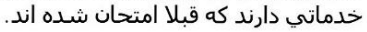

قهـ تعداد حط توليد محصول/خدمات بحديد طي 5 سال كذشته توسـط شـركت شـما بـه بـارار معرفى شـه اسدت؟ تعاد تول

\begin{tabular}{|c|c|c|c|c|c|c|c|c|}
\hline 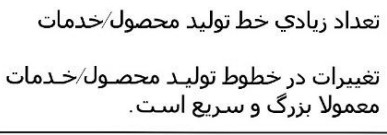 & 7 & 6 & 5 & 4 & 3 & 2 & 1 & 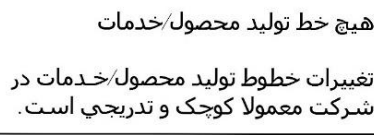 \\
\hline & & & & & & & & در رابطه با رقبا، شـركت ما ... \\
\hline 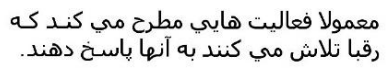 & 7 & 6 & 5 & 4 & 3 & 2 & 1 & 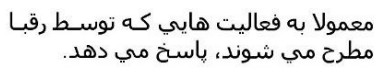 \\
\hline 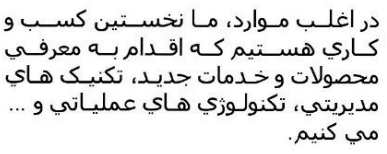 & 7 & 6 & 5 & 4 & 3 & 2 & 1 & 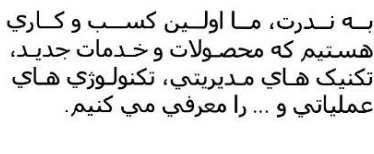 \\
\hline 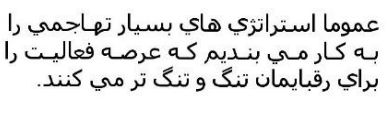 & 7 & 6 & 5 & 4 & 3 & 2 & 1 & 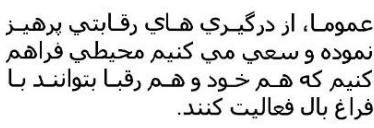 \\
\hline
\end{tabular}

به طور كلي، مديران ارشد سازمان ما (شامل خودتان). ...

تمايـل شــديدي بـه هــــيرش بــروزه هـاي

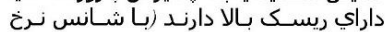
بازده بالاي

تمايل شـديدي بـه بـذيرش بـروزه هـايي

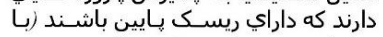

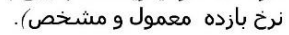

در رابطه با محيط اعتقاد دارند كه اقدامات

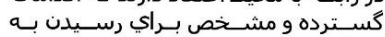
اهداف شـركت ضروري استــ

در رابطه با محيط اعتقاد دارند كه بهترين

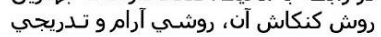

هنكام مواجحه با شرايط تصميم كيري كه عدم اطمينان بالايي در آن وجود دارد، شركت ما ...

عموما، استراتزي تعاجمي و ورو به به جلو رال

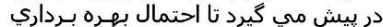

$\begin{array}{lllllllllllllll}7 & 6 & 5 & 4 & 3 & 2 & 1 & \end{array}$

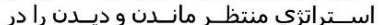
از فرصت هاي بالقوه را افزايش دهد. هزينه زا را كاهش دهر دهن. 


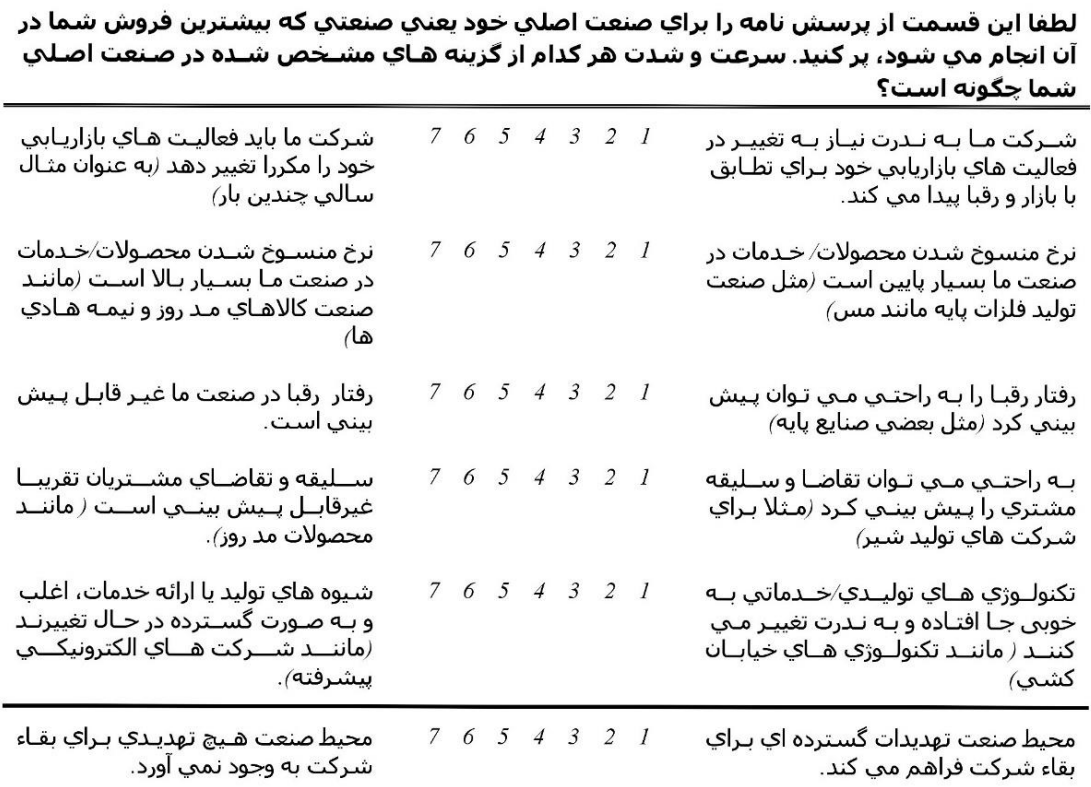

جالش هاي زير در صنعت مورد فعاليت شما جقدر شديد هستند:

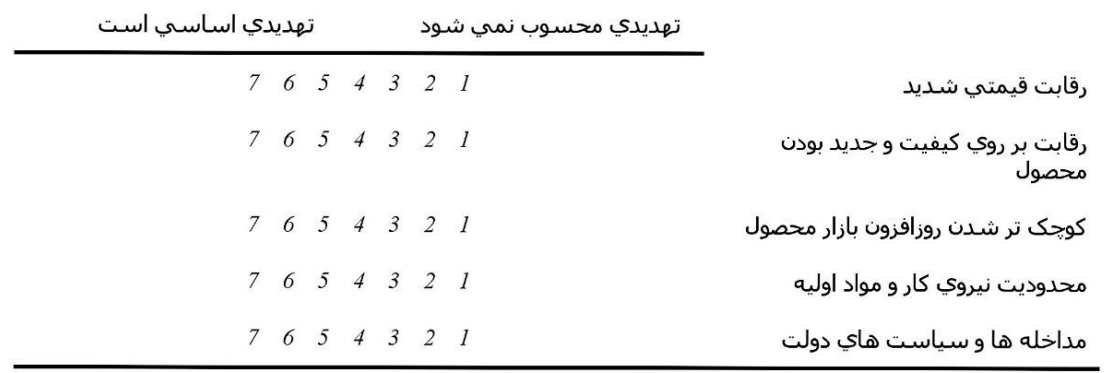

بازار خارحي مورد فعاليت در موارد زير بسيار شبيه به بازار بومي شركت است: كاملا نادرست كاملا درست

$\begin{array}{lllllll}7 & 6 & 5 & 4 & 3 & 2 & 1 \\ 7 & 6 & 5 & 4 & 3 & 2 & 1 \\ 7 & 6 & 5 & 4 & 3 & 2 & 1\end{array}$

از لحاظ قواعد زباني و ذهنيت افراد از لحاظ هنجارهاي اجتماعي- فرهنكي از لحاظ ارزش هاي اجتماعي - فرهنگي 


\section{Survey Questionnaire (English Version)}

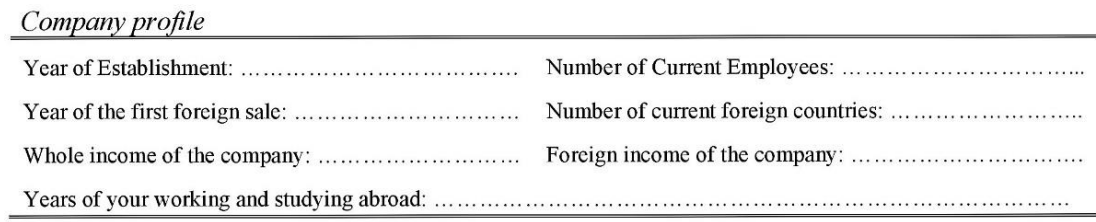

Over the past three years...

Strongly Disagree $\quad$ Strongly Agree

We have pioneered the development of breakthrough

122345567 innovation in our industry

Our organization is among the first to implement new

1234567 processes

We are usually the first to recognize and exploit new markets in our industry.

Our organization is leading in the area of product and process innovations.

We have introduced a large number of new products and services to the market.

Our organization has entered many new industries

12334567

We have expanded our international operations

significantly

We have acquired many companies in very different

industries

Our organization has created various new lines of

products and services

Our organization has established or sponsored various

new ventures

We have focused on improving the performance of our current business rather than entering new industries

We have divested several unprofitable units

Our organization has changed its strategy for each unit

We have initiated several programs to improve the

productivity of our units

We have reorganized operations to ensure increased

coordination and communication among units

Our organization has renewed the portfolio of activities

within units 
In general, the top managers of my firm...
A strong emphasis on the marketing of
1234567
A strong emphasis on R\&D, tried and true products or services technological leadership, and innovations

How many new lines of products or services has your firm marketed in the past 5 years?

No new lines of products or services

Changes in product or service lines have been mostly of a minor nature
1234567

1234567 Very many new lines of products or services

Changes in product or service lines have usually been quite dramatic

In dealing with its competitors, my firm . .

Typically responds to actions which competitors initiate

Is very seldom the first business to introduce new products/services, administrative techniques, operating technologies, etc.

Typically seeks to avoid competitive clashes, preferring a 'live-and-let-live' posture
1234567
Typically initiates actions which competitors then respond to
1234567
Is very often the first business to introduce new products/services, administrative techniques, operating technologies, etc.
1234567
Typically adopts a very competitive, 'undo- the-competitors' posture

In general, the top managers of my firm have...
A strong proclivity for low-risk
1234567
A strong proclivity for high-risk projects projects (with normal and certain rates
(with chances of very high returns) of return)

In general, the top managers of my firm believe that . .
Owing to the nature of the
12345667
Owing to the nature of the environment, environment, it is best to explore it bold, wide-ranging acts are necessary to gradually via timid, incremental achieve the firm's objectives

behavior

When confronted with decision-making situations involving uncertainty, my firm . . .

Typically adopts a cautious, 'wait-andsee' posture in order to minimize the probability of making costly decisions $\begin{array}{llllll}1 & 2 & 3 & 4567 & \text { Typically adopts a bold, aggressive }\end{array}$ posture in order to maximize the probability of exploiting potential opportunities 
Please answer the following questions for the industry that accounts for the largest \% of your sales (in other words, your principal industry). Always answer by circling the correct digit unless otherwise noted. How rapid or intense is each of the following in your main industry? Please circle the number in each scale that best approximates the actual conditions in it.

\begin{tabular}{|c|c|c|}
\hline $\begin{array}{l}\text { Our firm must rarely change its } \\
\text { marketing practices to keep up with } \\
\text { the market and competitors. }\end{array}$ & 1234567 & $\begin{array}{l}\text { Our firm must change its marketing } \\
\text { practices extremely frequently (e.g. semi- } \\
\text { annually). }\end{array}$ \\
\hline $\begin{array}{l}\text { The rate at which products/ services } \\
\text { are getting obsolete in the industry is } \\
\text { very slow (e.g. basic metal like } \\
\text { copper). }\end{array}$ & 1234567 & $\begin{array}{l}\text { The rate of obsolescence is very high (as } \\
\text { in some fashion goods and semi- } \\
\text { conductors). }\end{array}$ \\
\hline $\begin{array}{l}\text { Actions of competitors are quite easy } \\
\text { to predict (as in some primary } \\
\text { industries). }\end{array}$ & 1234567 & Actions of competitors are unpredictable. \\
\hline $\begin{array}{l}\text { Demand and consumer tastes are fairly } \\
\text { easy to forecast (e.g. for milk } \\
\text { companies). }\end{array}$ & 1234567 & $\begin{array}{l}\text { Demand and tastes are almost } \\
\text { unpredictable (e.g. high fashion goods). }\end{array}$ \\
\hline $\begin{array}{l}\text { The production/service technology is } \\
\text { not subject to very much change and is } \\
\text { well established (e.g. in steel } \\
\text { production). }\end{array}$ & 1234567 & $\begin{array}{l}\text { The modes of production/ service change } \\
\text { often and in a major way (e.g. advanced } \\
\text { electronic components). }\end{array}$ \\
\hline $\begin{array}{l}\text { The environment causes a great deal } \\
\text { of threat to the survival of our firm. }\end{array}$ & 1234567 & There is very little threat to survival. \\
\hline \multicolumn{3}{|c|}{ How severe are the following challenges: } \\
\hline & This is not a great threat & This is a very substantial threat \\
\hline Tough price competition & & 1234567 \\
\hline $\begin{array}{l}\text { Competition in product quality or } \\
\text { novelty }\end{array}$ & & 1234567 \\
\hline Dwindling markets for products & & 1234567 \\
\hline Scarce supply of labour/ material & & 1234567 \\
\hline Government interference & & 1234567 \\
\hline
\end{tabular}

The domestic country is very similar to the foreign country with respect to:

Very Untrue

Very True

\begin{tabular}{|c|c|}
\hline Mentality and Language & 1234567 \\
\hline Socio-cultural Norms & 1234567 \\
\hline Socio-cultural Values & 123456 \\
\hline
\end{tabular}




\section{Actors Information and Network Matrix}

\begin{tabular}{|c|c|c|c|c|c|c|c|}
\hline Index & Company Name & C-Type & C-Size & C-Influence & Int-Status & I-Type & I-strength \\
\hline $\mathbf{1}$ & & & & & & & \\
\hline 2 & & & & & & & \\
\hline 3 & & & & & & & \\
\hline 4 & & & & & & & \\
\hline 5 & & & & & & & \\
\hline 6 & & & & & & & \\
\hline 7 & & & & & & & \\
\hline 8 & & & & & & & \\
\hline 9 & & & & & & & \\
\hline 10 & & & & & & & \\
\hline 11 & & & & & & & \\
\hline 12 & & & & & & & \\
\hline 13 & & & & & & & \\
\hline 14 & & & & & & & \\
\hline 15 & & & & & & & \\
\hline 16 & & & & & & & \\
\hline 17 & & & & & & & \\
\hline 18 & & & & & & & \\
\hline 19 & & & & & & & \\
\hline 20 & & & & & & & \\
\hline
\end{tabular}

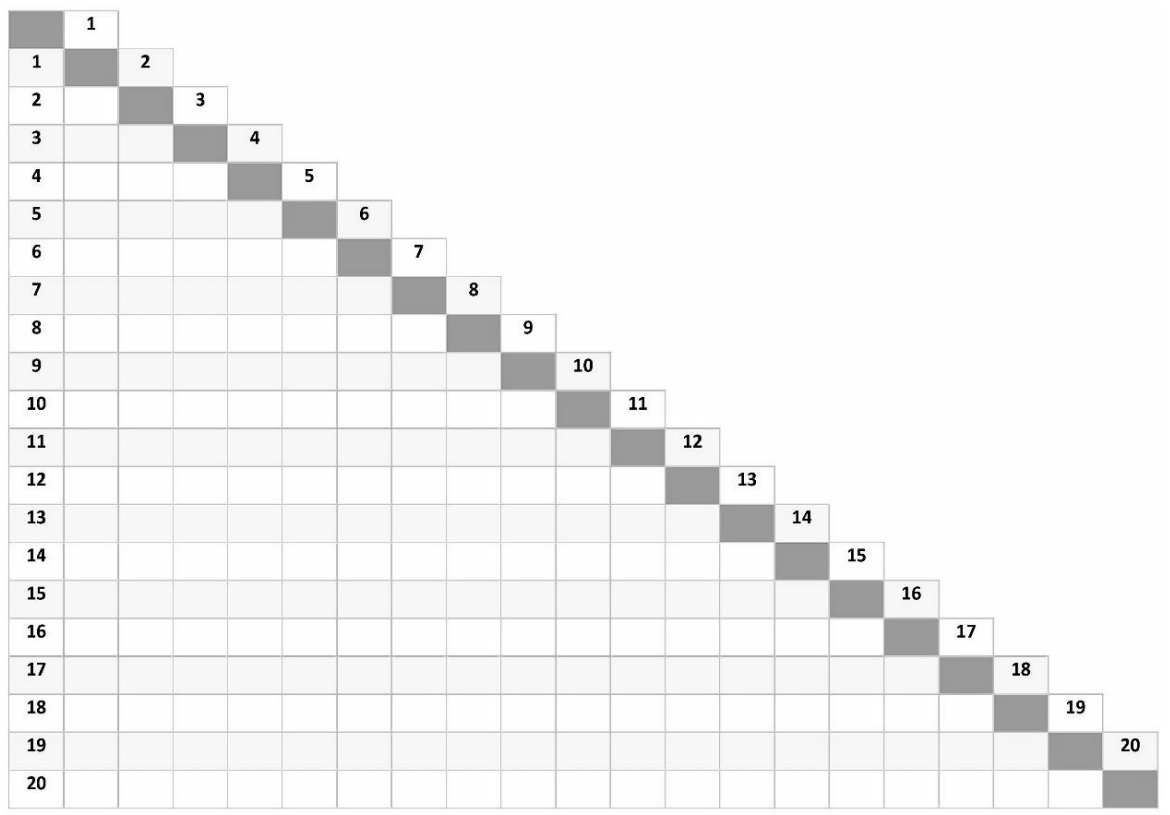




\section{Entrepreneurial Orientation (EO) Dimensionality}

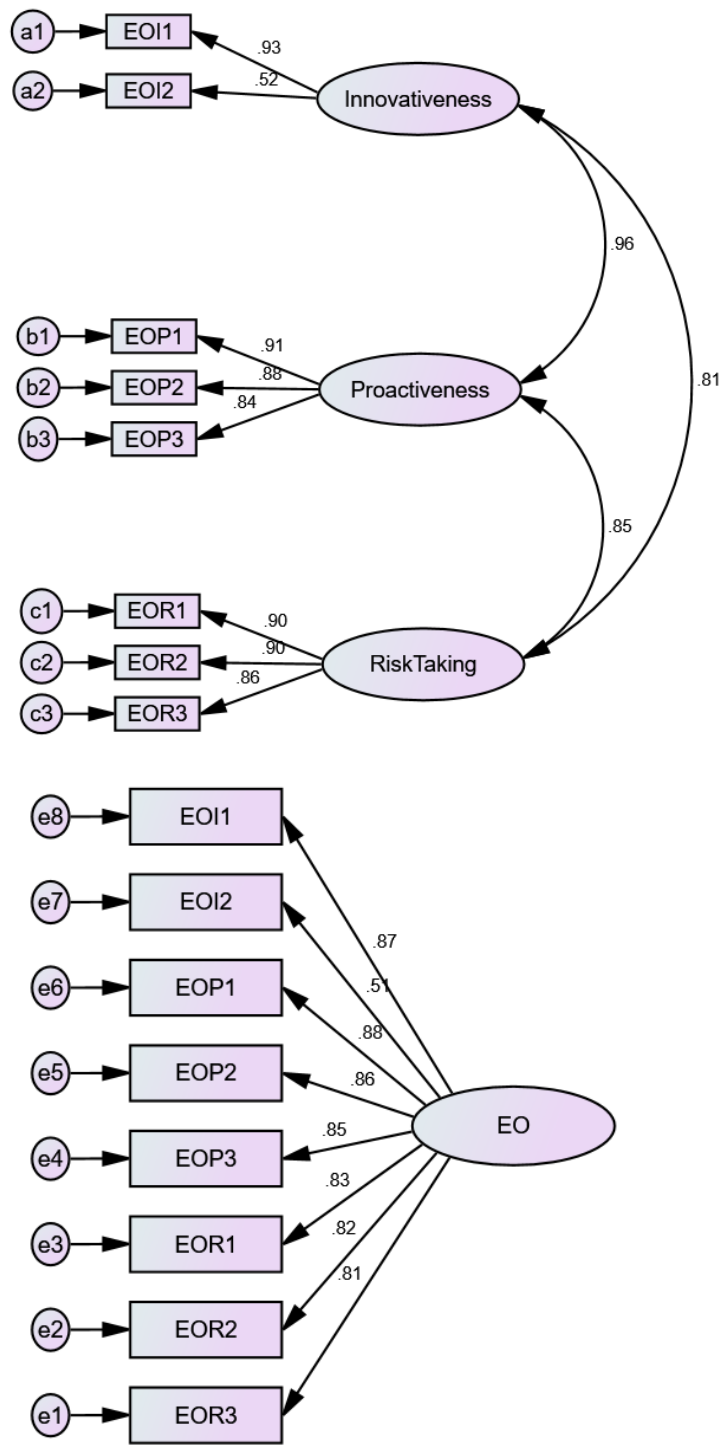


Corporate Entrepreneurship (CE) Dimensionality
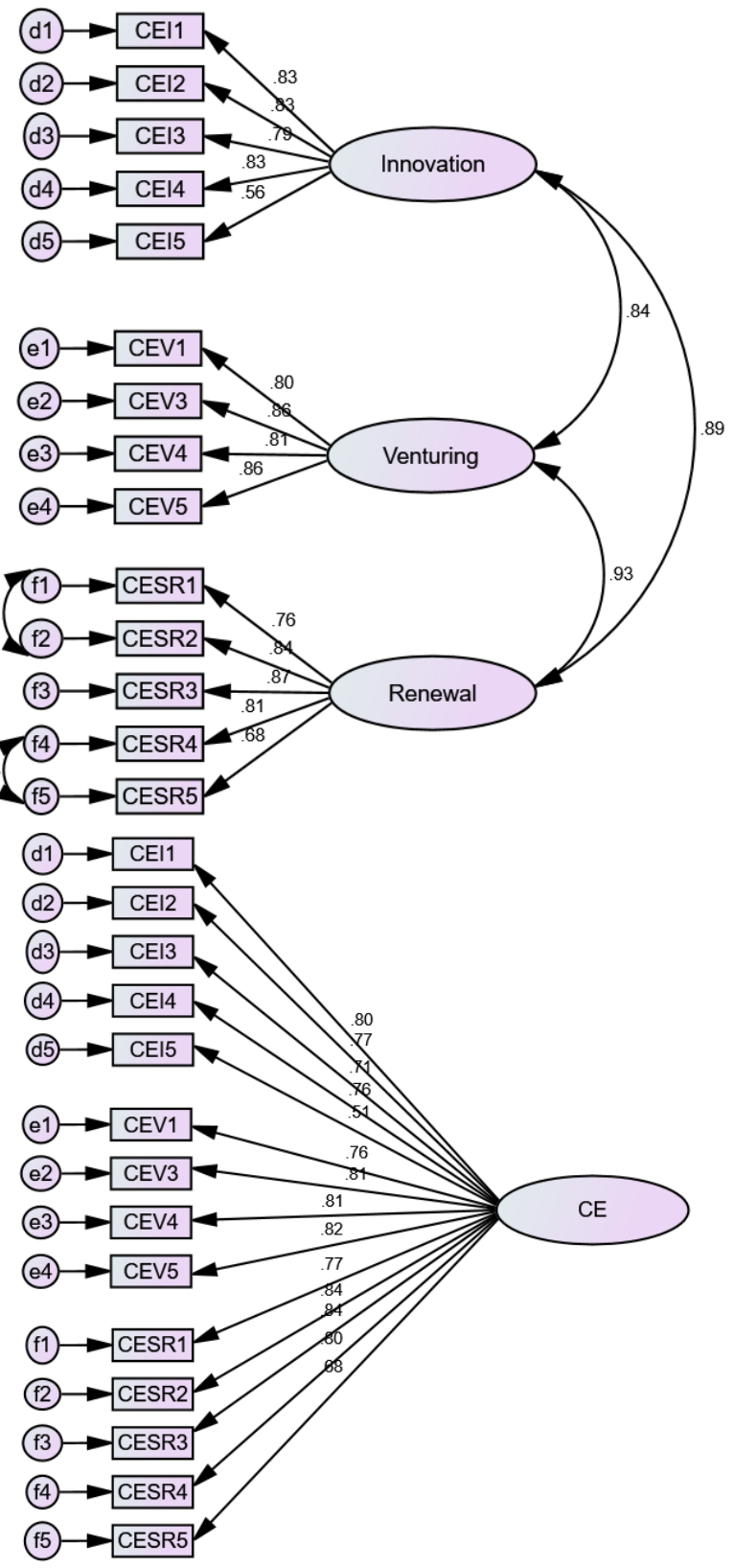


\section{Confirmatory Factor Analysis (CFA)}

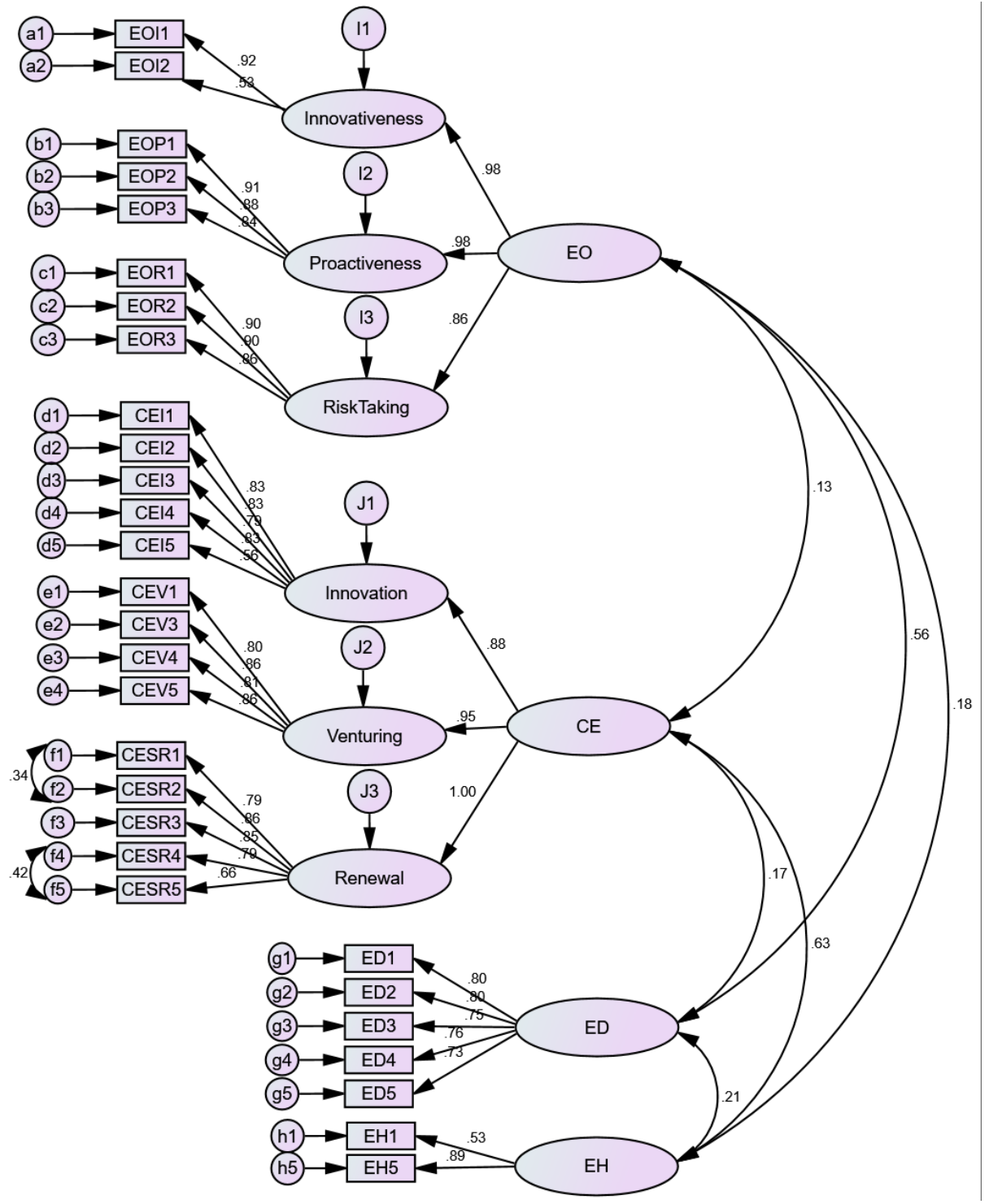


Tolerance and Variance Inflation Factors (VIF)

\begin{tabular}{|c|c|c|c|c|c|c|c|}
\hline & & Inte & $\begin{array}{l}\text { lational } \\
\text { ope }\end{array}$ & & $\begin{array}{l}\text { national } \\
\text { cale }\end{array}$ & Inter & $\begin{array}{l}\text { nalization } \\
\text { ed }\end{array}$ \\
\hline \multirow{10}{*}{ 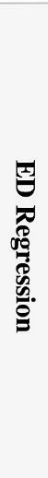 } & & VIF & Tolerance & VIF & Tolerance & VIF & Tolerance \\
\hline & Size & 1.301 & .769 & 1.301 & .769 & 1.292 & .774 \\
\hline & I-Experience & 1.128 & .886 & 1.128 & .886 & 1.129 & .886 \\
\hline & NE vs. Others & 2.030 & .493 & 2.031 & .492 & 2.031 & 492 \\
\hline & LE vs. (FE, AE) & 1.301 & .769 & 1.287 & .777 & 1.321 & .757 \\
\hline & FE vs. $\mathrm{AE}$ & 1.309 & .764 & 1.311 & .763 & 1.309 & .764 \\
\hline & ED (Centered) & 1.436 & .696 & 1.430 & 699 & 1.451 & .689 \\
\hline & $\mathrm{ED} *$ Contrast 1 & 1.654 & .605 & 1.654 & .605 & 1.652 & .605 \\
\hline & $\mathrm{ED} *$ Contrast 2 & 1.235 & .809 & 1.228 & .814 & 1.250 & .800 \\
\hline & ED*Contrast 3 & 1.088 & .919 & 1.087 & .920 & 1.091 & 917 \\
\hline \multirow{9}{*}{ 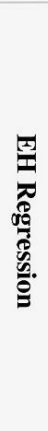 } & Size & 1.383 & .723 & 1.381 & .724 & 1.367 & .731 \\
\hline & I-Experience & 1.134 & .882 & 1.134 & .882 & 1.135 & .881 \\
\hline & NE vs. Others & 3.316 & .302 & 3.318 & .301 & 3.312 & .302 \\
\hline & LE vs. (FE, AE) & 1.179 & .848 & 1.169 & .856 & 1.174 & .852 \\
\hline & FE vs. AE & 1.377 & .726 & 1.387 & .721 & 1.372 & .729 \\
\hline & EH (Centered) & 1.894 & .528 & 1.901 & .526 & 1.898 & .527 \\
\hline & $\mathrm{EH} *$ Contrast 1 & 2.578 & .388 & 2.566 & .390 & 2.575 & .388 \\
\hline & EH*Contrast2 & 1.147 & .872 & 1.147 & .872 & 1.137 & .880 \\
\hline & EH*Contrast 3 & 1.265 & .790 & 1.267 & .789 & 1.268 & .789 \\
\hline
\end{tabular}

